ALBERT CAMUS' CRITIQUE OF MODERNITY 


\title{
ALBERT CAMUS' CRITIQUE OF MODERNITY
}

By

RONALD D. SRIGLEY, B.A., M.A.

\author{
A Thesis \\ Submitted to the School of Graduate Studies \\ in Partial Fulfilment of the Requirements \\ for the Degree \\ Doctor of Philosophy
}

McMaster University

(C) Copyright by Ronald D. Srigley, November 2008 
DOCTOR OF PHILOSOPHY (2008)

(Religious Studies)
McMaster University

Hamilton, Ontario

\author{
TITLE: Albert Camus' Critique of Modernity \\ AUTHOR: $\quad$ Ronald D. Srigley, B.A., M.A. (McMaster University) \\ SUPERVISOR: $\quad$ Professor Zdravko Planinc \\ NUMBER OF PAGES: v, 383
}




\begin{abstract}
The aim of my study of Camus is twofold. The first aspect concerns the content of his books, the second their formal structure or organization. In contrast to much current scholarship, which interprets Camus' primary concerns as modern and even post-modern, I argue that his ambition runs in the opposite direction historically: Camus' principal aim is to articulate a Greek anthropology and political philosophy. This positive ambition has a critical component as well. Camus's Hellenism is formulated in part through a critical engagement with modernity and an exploration of its Christian origins.

The second aim of my study is to explore the structure of Camus' corpus. The fact that Camus organized his books into several different stages or "cycles" is well known and often discussed by commentators in the context of other interpretive matters. However, it is rarely examined in its own right and almost never interpreted in detail. The most common way that it is understood is as straight autobiography. In this view the absurd, rebellion, and love - the guiding themes of the three principal cycles of Camus' books - are understood as stages in his personal philosophical development. The account contradicts Camus' own explicit statements about the allegedly autobiographical character of his work and skirts the fundamental question of interpretation by assuming that it has already been answered. Contrary to this account I argue that the organization of Camus' books is an intentional literary device that contributes significantly to our understanding of the content of his work.

My study amounts to new interpretation of Camus that hopefully will open up new and fruitful avenues of research regarding his accomplishments as a philosopher and writer.
\end{abstract}




\section{ACKNOWLEDGEMENTS}

A hearty thanks to Dr. Zdravko Planinc for his supervision of this dissertation. His magnanimity and keen insight were instrumental in its completion and decisive for its content. Thanks also go to Dr. Dana Hollander for her careful reading of the text and the engaging questions she raised concerning its argument. Thanks to Dr. Louis Greenspan for his constant encouragement and his willingness to join the committee in difficult circumstances.

I also owe a big thanks to my sister, Susan Srigley, for her generous efforts on my behalf. My mother has been unfailing in her support over the years, never complaining, never doubting. And my sister Elizabeth admirably fulfilled her role as eldest sibling by scolding me on occasion when I truly needed it. To my father let me say that perhaps now we can finally change the subject.

Many thanks to the guys - William and Elliott - for being fun even when I wasn't and for making it all worthwhile. My best thanks go to Kate. We trundled up this difficult hill together, darling. Now from its height I see many fine and wonderful things ahead. Shall we? 


\section{TABLE OF CONTENTS}

Introduction

Notes

PART ONE: THE HISTORICAL ESSAYS

Introduction $\quad 62$

Notes 66

Chapter One: The Absurd Man $\quad 67$

Notes $\quad 118$

Chapter Two: A History of Rebellion $\quad 127$

Notes

PART TWO: TWO WORKS OF FICTION

Introduction 194

Notes 197

Chapter Three: Modernity in its Fullest Expression $\quad 198$

Notes $\quad 287$

Chapter Four: Before the Fall 307

Notes $\quad 350$

Conclusion $\quad 363$

Notes $\quad 374$

Bibliography $\quad 376$ 
Ph.D. Thesis - R. Srigley McMaster - Religious Studies

\section{INTRODUCTION}

In the fall of 1947 Albert Camus wrote in his Notebooks: "If, to outgrow nihilism, one must return to Christianity, one may well follow the impulse and outgrow Christianity in Hellenism." A few years later Camus restated the matter more forcefully and in a way that cleared up any lingering ambiguity about where the line should be drawn between the ancients and the moderns: "Go back to the passage from Hellenism to Christianity, the true and only turning point in history."2 Camus acknowledges a difference between Christianity and modernity at the same time that he implicates Christianity in the modern project. He also makes it clear that for him the Greeks alone possess an account that is free of the limitations of both traditions. In 1957 Camus goes farther. He now states openly that Christianity is complicit in the modern project and announces his opposition to both as a central feature of his proposed third philosophical essay, The Myth of Nemesis: "Nemesis: The profound complicity between Marxism and Christianity (to develop). That is why I am against them both."” A year later, in April 1958, he states his own positive ambition in these terms: "The world marches toward paganism, but again it rejects pagan values. We must restore them. We must paganize belief, grecesize the Christ and restore balance." ${ }^{4}$

These bold claims indicate a direction in Camus's thought that was first articulated and explored in Christian Metaphysics and Neoplatonism and is apparent in 
Ph.D. Thesis - R. Srigley McMaster - Religious Studies every major work he has written since. That direction entails two central features. These features form the heart of Camus' philosophical project as I have been able to understand it. The first is a critique of modernity and an explanation of Christianity's complicity in the modern project. As early as The Myth of Sisyphus Camus argued that there is nothing to choose between Christianity and modernity, because despite their phenomenal differences and in comparison with his own Greek account, their manner of interpreting and responding to the basic character of life is structurally the same. He adds to the argument and further develops it in The Rebel, where he explores the origins of all developmental accounts of history and explains the nature and consequences of the modern political movements that were their logical successors. The Fall rounds out the critical analysis with Camus' best account of the nature of modernity. In this book Camus bypasses the more common versions of the modern world - rebellion, absurdity - and goes right to the heart of the matter. The madness and violence of modernity is a consequence of an erotic disturbance that has insinuated itself into virtually every aspect of the contemporary world. For Camus that disturbance received its fullest expression in modern totalitarianism. However, it is also a basic feature of Western liberal democratic regimes committed to science and technology and the rational control of nature. Indeed Camus argues that in this regard and on the economic plane liberal regimes and totalitarian regimes form "one world." The persuasiveness of Camus' account is due precisely to its Greek character and its freedom from modern and Christian assumptions. 
Ph.D. Thesis - R. Srigley McMaster - Religious Studies In all these works Camus patiently refines his critique of modernity.

The second feature of Camus' project concerns an interpretation of the Greeks and an explanation of why we should prefer them to Christianity and modernity. The Greeks were the very foundation of Camus' thinking and a source to which he turned early and often in his attempt to make sense of his own experience and of the world in which he lived. His early observation that perhaps the whole meaning of the Odyssey lay in Odysseus' refusal of Kalypso's offer of immortality is typical in this regard. ${ }^{6}$ Though slightly reductive as interpretation, it is a stunning insight and quite illuminating regarding Camus' analysis of the apocalyptic movements of his time. Camus' earliest notebooks are filled with such discussions of ancient political and literary works and of their relevance for his assessment of modernity. ${ }^{7}$

Camus developed these insights into sustained arguments in his published works. The very structure of his oeuvre was designed as a mediation in the medium of the Greek myth. ${ }^{8}$ Each of the three stages that constitute the well-known cyclical structure of Camus' books is organized around a central Greek myth: the absurd: the myth of Sisyphus; rebellion: the myth of Prometheus; and love: the myth of Nemesis. ${ }^{9}$ Each successive stage of Camus' attempt to understand the nature of modernity was simultaneously a movement toward the very heart of the Greek world. The Greeks were for Camus both the measure for his critical analysis and an object of study, the aim of his positive effort to discover a genuine alternative to the Christian and modern traditions 
Ph.D. Thesis - R. Srigley McMaster - Religious Studies

with which he was confronted.

The overwhelming importance of the Greeks for Camus' project is immediately apparent to anyone who reads his books. So too is his interpretation of the relationship between modernity and Christianity and his critical assessment of both traditions. Yet these features of Camus' work are little understood and rarely discussed by commentators. How are we to explain this neglect? If we examine its character closely, certain patterns of interpretation emerge.

Camus' philosophical commentators divide naturally into two basic groups: Christians and moderns. Of course there are non-partisans who do not fit neatly into either of these camps. There was a wave of excellent readers in the ' 60 s and ' 70 s who were primary sources in their own right and who began to appreciate the depth of Camus' critique of modernity and its compatibility with their own work. ${ }^{10}$ But their interpretations were as brief as they were insightful and their influence did not last. By and large it has been Christians and moderns who have set the terms of the debate over the nature of Camus' achievement. And those terms were conceived in such a way as to force Camus to participate in the debate between them as the defining feature and central ambition of his work. The effective truth of this procedure was to silence Camus' Greeks without ever having understood or interpreted them and to dismiss the most important insight of his critical analysis by reinforcing the common perception that the choice between modernity and Christianity was a real one and perhaps even the only one available to us. Thus has 
Ph.D. Thesis - R. Srigley McMaster - Religious Studies

Camus been impressed into service on both sides of the debate, at one moment a modern critic of Christianity, at another a critic of modernity with Christian sympathies, though always falling just a little short of the given commentator's preferred position.

Consider Bernard Murchland's work in this regard. Murchland argues that in the late '50s Camus was moving toward a religious position of some kind. He says that "the development of [Camus'] work must, if it continues, ultimately culminate in some spiritual position." Murchland goes on to say that Camus' novel The Fall might signal "the dark night before the coming of grace." indicates that the spiritual position Murchland has in mind is Christianity. The Fall articulates the religious need, but offers no fulfillment. Camus' work is therefore only half done. For Murchland he is almost a Christian.

Several years before Murchland published his essay Camus himself had responded to this style of interpretation. During an interview with Le Monde he denied explicitly the claim, made by some readers, that The Fall signaled a "rallying to the spirit if not the dogma of the Church": "Nothing really justifies them in this. Doesn't my judge-penitent clearly say that he is Sicilian and Japanese? Not a Christian for a minute. Like him, I have a good deal of affection for the first Christian. I admire the way he lived, the way he died. My lack of imagination prevents me from following him any further. There, in parentheses, is my only similarity to the Jean-Bapiste Clamence with whom people stubbornly insist on identifying me."12 
Ph.D. Thesis - R. Srigley McMaster - Religious Studies

Though less optimistic about the outcome of this insight, Jean Onimus makes a similar argument. He agrees with Murchland that there is a religious dimension to Camus' thought. He cites Camus' own admission of having a "natural sense of the sacred" as evidence in this regard. ${ }^{13}$ But he claims that because Camus' gods are "terrestrial" as opposed to transcendent or supernatural, he was ultimately left with a "stagnant universe, a benighted chaos where human folly blazes."14 Both Murchland and Onimus interpret Camus' books in light of standards of meaning he does not accept and that are not apparent in his writings. Whatever their intentions in doing so, the results are essentially the same: apologetic readings that say a good deal more about their respective authors than they do about Camus.

Modern commentators have not fared much better than the Christians in this regard. After a valiant and amusing attempt to turn Camus into his antithesis (a modern historicist communitarian) and to dismiss his deepest and most abiding concern (the Greeks and their teachings about nature) as a "pre-reflective fringe" of his thought, David Sprintzen claims that even at his best Camus was still not quite as good as Sartre. "No wonder that when Camus comes to write about Marx, while appreciating the incisiveness of the Marxian critical analysis as well as the dangers of the Marxian prophetic tradition, he totally misses (as Sartre suggested) the center of Marx's vision: humanity's collective self-creation through time-in short, Marx's philosophical anthropology." ${ }^{" 16}$ Never mind that this question was an essential part of Camus and Sartre's disagreement and therefore 
Ph.D. Thesis - R. Srigley McMaster - Religious Studies anything but pre-reflective; and never mind that it rests on an even more fundamental disagreement between them about the ancients and the moderns that goes back at least to The Myth of Sisyphus and perhaps even earlier. ${ }^{17}$ All it requires is an addition here and an omission there and Sprintzen is able to turn Camus into a willing but failed modern just as surely as Murchland and Onimus were able to turn him into a willing but failed Christian, the emphasis falling on willing or failed according to the individual commentator's taste. This is a common tendency in all ideological thinking. You silence an opponent not through direct argument but by forbidding him to be an opponent. A prototypical version of yourself, particularly an inferior one, is much more easily handled than a real enemy. Effectively it ensures that the only voice to be heard in the exchange is your own. It is criticism posing as interpretation and it reflects the modern aspiration to totality for which genuine difference or otherness is a marginal concern at best.

A failed modern is not a Christian but a modern, and so too is a failed Christian. With the Greeks effectively silenced, the only remaining place for Camus was therefore one or another corner of the modern project. For a leftist intellectual like Sprintzen, it was simply an earlier historical dispensation of that project. Camus was a recovering colonialist and bourgeois, enamoured of nature and seduced by private thoughts and individual despair, but struggling mightily to rejoin history. ${ }^{18}$ For a Christian writer like Onimus, Camus was a modern nihilist simply, and this despite his gods and despite his "sense of the sacred." It would seem that for Onimus the range of possible human lives 
Ph.D. Thesis - R. Srigley McMaster - Religious Studies had contracted so completely that he could not image an experience of meaning or purpose apart from acceptance of the Christian teachings about God and the future life. Failing that, all that remained for Camus was a "benighted chaos were human folly blazes." This is not merely the idiosyncratic preference of a peculiar French Catholic writer. It is an essential element of orthodox Christian dogma and is echoed in the works of some of Camus' most sympathetic Christian commentators. ${ }^{19}$

The proper philosophical name for the corner of modernity to which Camus has been consigned by his commentators is existentialism. It is a term that has been used to describe Camus' work for the better part of the last sixty years. Pick up any philosophy textbook and turn to the section entitled existentialism, and there you will find him listed along side the likes of Kierkegaard, Heidegger, and Sartre. Compared with the other misnomers he might have received, existentialist is in some ways not a terribly damning one. In the hands of an non-ideological twentieth century critic, it usually means simply heroic or non-fanatical nihilist. Given the current state of the debate in North America, one might just as well say liberal. In any event, as harmless as it may be at this journalistic level of analysis, the appellation is highly misleading and robs us of what is most striking and important in Camus' books and of his best insights when we consider his achievement more seriously. The great irony is that this writer, who has become the poster boy for modern existentialism, was one of modernity's most astute critics and one of the very few who genuinely understood and challenged the teachings of existentialism. 
Ph.D. Thesis - R. Srigley McMaster - Religious Studies It does not seem to matter that Camus denied publically and repeatedly that he was or ever had been an existentialist; nor does it seem to matter that the only book-length study he devoted to the subject was explicitly and resolutely critical of all schools of existentialist thought; ${ }^{20}$ contemporary scholarship has insisted and continues to insist that Camus' highest achievement was a rather conventional anti-foundationalism coupled with a robust encounter with the world's meaninglessness. ${ }^{21}$ There is nothing much new here, and it is difficult to believe that such insights could have won Camus the approbation of writers the caliber of Martin Buber, Hannah Arendt, and Eric Voegelin, to say nothing of the thousands of non-academic readers who found in Camus' books something they did not find in those of men like Sartre or Marx. ${ }^{22}$

Despite his alleged existentialism Camus always comes off unfavourably in comparisons with Sartre, the true gatekeeper of that philosophical school in France and Camus' most famous critic. The common view was that while Camus may have been a sound moralist and a better novelist, Sartre was the real philosopher of the two. ${ }^{23}$ The view's influence was due largely to Sartre himself. In his response to Camus' letter to Les Temps modernes regarding its review of The Rebel, Sartre stated publically that Camus' analysis was at best derivative and sophomoric.

Tell me, Camus, by what mystery may we not discuss your books without depriving humanity of its reasons for living?... And what if you are wrong? What if your book simply testifies to your philosophical incompetence? What if it 
Ph.D. Thesis - R. Srigley McMaster - Religious Studies consisted of hastily gathered and secondhand knowledge?... I have at least this in common with Hegel: you haven't read either one of us. But what an odd habit you have of not going to the sources... I dare not refer you back to Being and Nothing, the reading of which would seem unnecessarily arduous to you: you detest difficulties of thought and hastily declare that there is nothing to understand in order to evade the reproach of not having understood. ${ }^{24}$

There is no reason to take Sartre's work or his highly polemical remarks as the measure of Camus' ability to think philosophically, though this is common practice today. ${ }^{25}$ Sartre was an extremely capable intellectual, but a third-rate thinker at best. Camus was an entirely different story. ${ }^{26}$ Whatever problems may be apparent in The Rebel, they are not due to any philosophical incompetence on his part. Just the opposite is true. They are the normal and perhaps inevitable confusions and hesitations that attend any effort to think about an old problem in a new way or to change the terms of the debate. Camus may have found modernity's this-worldliness helpful as a means of overcoming analytically Christianity's denigration of nature. But even in his earliest books there is evidence that he was not convinced that modernity itself managed to escape that same denigration. Indeed in these and other works there is a strong sense that modernity had actually continued and perhaps even exacerbated the Christian problematic.

As Camus' thought matured his critique of Christianity and his critique of modernity began to merge to form a single critical insight. The content of that insight took shape slowly in books like The Myth of Sisyphus and The Rebel, as well as in a series of shorter "lyrical" essays. As it did so the terms of Camus' analysis also began to 
Ph.D. Thesis - R. Srigley McMaster - Religious Studies change. His earlier distinction between this world and the other world ${ }^{27}$ as his principal analytic tool shifted in order better to account for the similarities between the two traditions and their shared confusion. The Rebel is something like a mid-way point in this development. The this world/other world formulation or immanentization argument ${ }^{28}$ of The Myth is still apparent in the analysis, but it now exists uneasily alongside a new formulation that Camus introduces in order to capture the totalizing character of both traditions and to lead him closer to the real heart of the problem. The "All or Nothing" analysis of The Rebel does not simply repeat Camus' earlier argument. The All is not God and the Nothing is not the world, though they have been read that way by some commentators. ${ }^{29}$ Rather these terms denote a human aspiration to totality that Camus argues can be found just as well in the transcendent or Christian historiography of Joseph de Maistre as in the immanent historiography of Marx or Lenin. ${ }^{30}$ This is the analysis that would gradually take shape in early and middle fifties. Though it is more compelling than the one that preceded it, in The Rebel its significance and consequences are only partially worked out and are rendered ambiguous by the fact that they have to compete awkwardly with elements of the earlier analysis that Camus had still not abandoned entirely. In his "Reply to Albert Camus" Sartre exploited these confusions and hesitations to his own advantage while ignoring the central thrust of the analysis: namely, the apocalyptic character of all modern revolutionary movements, their affinity with certain Christian teachings, and the attempt to articulate an alternative free of the excesses of 
Ph.D. Thesis - R. Srigley McMaster - Religious Studies both accounts. He argued that although Camus had understood the illusory character of all forms of meaning, whether metaphysical or religious, he continued to grapple with their absence as a fundamental feature of his thinking. ${ }^{31}$ This was particularly true in the case of religion. God may be a fiction but he was still real enough for Camus to lament his disappearance and to protest against his silence. Nature for its part became a sort of refuge from the madness and violence of history. But this was both reactionary and inconsistent with Camus' own absurdism and his critique of Christianity. With God dead nature died too. For Sartre there was therefore no going back. "It seems to you that the world offers the same riches as in the past and that it is men who do not want to see them; well then, reach out your hand and see whether it does not all vanish: Nature itself has changed its meaning because the relationships men maintain with it have changed."32 The remainder of Sartre's reply is straightforward Marxist critique. With God and nature dead, all that remains is history and the human effort to "give" it meaning. ${ }^{33}$ But Camus refused to participate in that effort. To the real struggles of history, which were ugly and more violent because they were directed against human beings who impede history's progress, Sartre argued that Camus preferred his illusory struggles against a non-existent god and a silent nature. ${ }^{34}$

You refused the Soul and the Idea. But since, according to your own terms, injustice is eternal - that is to say, since the absence of God is constant through the changes of history - the immediate and always renewed relationship of the man who demands to have a meaning (that is to say that one be given to him) to this God who remains eternally silent, itself transcends History. The tension 
Ph.D. Thesis - R. Srigley McMaster - Religious Studies

through which man realizes himself - which is, at the same time, an intuitive joy of being - is therefore a veritable conversion which he snatches from his everyday 'agitation' and 'history' in order to make it coincide finally with his condition. One cannot go any further; no progress can be found in this instantaneous tragedy. ${ }^{35}$

Sartre's reply to Camus was as effective as it was disingenuous. It is extremely illuminating of the intellectual climate of opinion in France at the time that Sartre was considered almost unanimously to have won the debate, the sophistic nature of his arguments notwithstanding. Even Camus' friends and supporters were of the opinion that he had been bested by Sartre. ${ }^{36}$ Ronald Aronson has recently offered a more even-handed assessment. He argues that both men's arguments have "the ring of one-sided truth" and that the legitimate insights of what might otherwise have been a private and fruitful exchange between friends were lost in the violence of a public debate that was essentially political and therefore concerned with victory far more than truth. ${ }^{37}$ As to the substance of their disagreement, one thing Aronson argues is that rather than answer the specific objections that Camus had raised in his letter, particularly his central argument about the violence and immoralism of the modern revolutionary movements Sartre was recommending and supporting, Sartre merely "changed the subject" all the better to destroy Camus publically. ${ }^{38}$ There is much good sense in Aronson's analysis and a very helpful account of the history of the relationship between the two men. But I think we can go even further in the analysis of Sartre's reply to Camus and in explaining what it was about Camus' account that Sartre seems to have resisted or failed to understand. 
Ph.D. Thesis - R. Srigley McMaster - Religious Studies

Sartre did not merely change the subject of his debate with Camus; he also changed the subject of Camus' book, in much the same way that Jeanson did in his initial review of The Rebel for Les Temps modernes. One of the complaints that Camus makes repeatedly in his letter to Sartre is that Jeanson grossly misrepresents his argument all the better to dismiss it. Here is one example: "Your collaborator has preferred to suppress history in my reasoning the better to be able to accuse me of suppressing it in reality... Your article, here as in the entire work, replaces historicism with history, which, in effect, suffices to transform the book into its opposite and its author into an unrepentant idealist. ${ }^{.39}$ Nothing really changes in Sartre's response. The distinction between history and ideals to which Camus refers is a derivation of the distinction between this world and God and perhaps also of the distinction between history and nature that Sartre uses to interpret his analysis. Sartre's first move is essentially the same as Jeanson's: quietly and without argument he equates history with Marx's brand of revolutionary historicism. ${ }^{40}$ As Camus says in his letter, since he is critical of all forms of historicism, the practice has the effect of denying to him any meaningful sense of history at all. And when this assertion is coupled with the assumption that history and nature or history and God are antithetical realities between which one must choose, it requires only a short step to place Camus in the latter camp and to dismiss him altogether as an idealist, a reactionary, or even a reluctant believer. ${ }^{41}$

Sartre misrepresents Camus' argument even more skillfully than does Jeanson. 
Ph.D. Thesis - R. Srigley McMaster - Religious Studies Apart from a few scattered exceptions, the extraordinary thing is that in doing so he set the interpretive parameters that would guide Camus scholarship for the next fifty years. To a contemporary non-partisan reader the scope and influence of the misrepresentation is staggering. Although Camus does at times falter in The Rebel and occasionally resorts to the kinds of antitheses and assumptions apparent in Sartre's analysis, try to escape those assumptions he most certainly does. No sensitive reader of The Rebel can deny that it is precisely these sorts of antitheses - between nature and history, history and God, the real and the ideal - that Camus is seeking desperately to overcome. Christians may speak about God in a way that Camus could not accept. But the modern negation of all transcendence and any sense of the sacred seemed equally implausible to him. ${ }^{42}$ And how could one offer a compelling account of the basic character of life if one was forced from the outset to abandon or ignore things that do not move or change (nature) in favour of things that do (history), or the reverse? The Marxist and existentialist notion that meaning is something human beings simply make through historical action was for Camus too proud and too naive to explain experientially both the wonder of human life and its heartbreaking and tragic nature. ${ }^{43}$

What Camus was attempting to articulate in The Rebel was an account that did not seek to answer the Christian/modern problematic on its own terms but to reveal the inadequacies of both traditions and to encourage a new exploration of human experience that did not labour under the distorting influence of either tradition's assumptions. This 
Ph.D. Thesis - R. Srigley McMaster - Religious Studies

was an ambitious undertaking which in The Rebel Camus only partially succeeds in completing. ${ }^{44}$ But it was an undertaking for which Sartre apparently had neither the stomach nor the inclination. For all his anti-authoritarian rhetoric and his avowed atheism, Sartre was the one who remained firmly within the orbit of the Christian understanding while Camus bravely and unpopularly forged ahead to free himself from it completely. Be that as it may. Though this renewed exploration of human experience could be undertaken just as well through an examination of the works other gifted modern writers - Melville, Nietzsche, Faulkner, Char - for Camus the best way to accomplish it was to return once again and wholeheartedly to the real source of what is truest and best in us: the Greeks. ${ }^{45}$ They represent the only living tradition in the West that is entirely free of Christian and modern prejudices. Getting back to them, however, would be not be easy. For Camus it meant first passing through and understanding those things that separated us from them. His sober assessment of the difficulty of that task is apparent in the iconography he employed to describe it:

The year the war began, I was to board a ship and follow the voyage of Ulysses... But I did what everyone else did at the time. I did not get on that ship. I took my place in the queue shuffling toward the open mouth of hell. Little by little, we entered. At the first cry of murdered innocence, the door slammed shut behind us. We were in hell, and we have not left it since. For six long years we have been trying to come to terms with it. Now we glimpse the warm ghosts of fortunate islands only at the end of long, cold, sunless years that lie ahead. ${ }^{46}$

What was it for Camus that made modernity hell? And what was it about the modern 
Ph.D. Thesis - R. Srigley McMaster - Religious Studies project that made it so difficult to overcome, both practically and analytically? To reduce something as complex as modernity to a single leading idea would no doubt be to oversimplify matters; yet if such a reduction were permitted, then I would say that the utopian or apocalyptic character of modernity is what best defines it. Camus does his best to investigate all the elements of the contemporary world, from its political structures to its literature to its pragmatic organization and ambitions. Yet he always comes back to this single explanatory idea when trying to understand what modernity is essentially. What does it mean?

The feature that is common to all apocalyptic movements, whether revolutionary or Christian, ancient or modern, is the notion that our present world is radically imperfect and therefore must be superceded by a new and perfect world. The appeal of these movements lies herein: it is their promise of another world that is free of the pain and suffering of this one. Each apocalypse has its own account of the origin of that pain and suffering and therefore its own particular account of how it might be overcome. But their shared hope for such an overcoming unites them in a common aspiration. As Camus says, apocalyptic thinkers do not aim to understand the world but to transform it. ${ }^{47}$ All their efforts are directed toward the achievement of this end. So ingrained is this idea that even some of modernity's most effective critics sometimes concede its claim to absolute novelty, if only to dismiss its achievements as deformative.

The psychology behind this apocalyptic aspiration that Nietzsche examined so 
Ph.D. Thesis - R. Srigley McMaster - Religious Studies carefully in The Genealogy of Morals and The Anti-Christ is something that Camus tackles only partially in his cyclical books. ${ }^{48} \mathrm{~A}$ fuller and more direct treatment does not come until The Fall, though there are intimations of it elsewhere. What Camus spends most of the middle part of his career doing is sorting out and explaining the consequences of this type of apocalyptic thinking. The first consequence is the most important and the one from which the others follow. If you want to give the world a meaning other than the one it has, or to make its movement toward another, perfect world seem plausible, you first have to remove the original meaning and the limits it places on such aspirations. Existentialism certainly cooperated in that project, though its own apocalyptic ambitions are often either muted or made to appear as later additions not properly a part of the original account. Nevertheless, like all modern philosophies it sought to rescue humanity from religious, philosophical, and political oppression by undermining the notion of a natural order on which those forms of oppression relied for their legitimacy. Nature means limits, and limits limit the freedom or liberation that is the principal aim of all modern philosophies, including existentialism. They must therefore be removed.

In The Rebel Camus says that the real consequence of that desire for liberation was to "empty the world of its substance. ${ }^{\$ 49}$ Though the immediate object of this critical remark is Christian providentialism, it applies equally well to all modern apocalyptic movements. ${ }^{50}$ The complete freedom promised by apocalyptic thinkers requires the absence of any kind of restraint. The removal of the world's substance is therefore a 
Ph.D. Thesis - R. Srigley McMaster - Religious Studies condition of that freedom, not an accidental or unintended consequence of its achievement. The providentialism that characterizes these movements is no objection here and does not contradict the desire for liberation. The providential movement is the liberation the apocalyptic thinker seeks. It is reality rewritten according to the dictates of his desire and without the constraints of the old world he wishes to leave behind.

In The Myth of Sisyphus Camus claims that the consequence of this loss of the world's substance is a corresponding loss of human substance. This is a precise description. The world's meaninglessness does not free Camus' absurd man for heroic acts of self-creation; it is a mirror image of his own emptiness and tempts him to match it through an act of self-destruction. If nothing has any meaning, then neither do I, and suicide is a matter of indifference at best. What saves him from this fateful conclusion is a reconsideration of his initial assertion. He discovers that the sense of meaninglessness from which he suffers is neither in the world nor in himself, but in the misrelation between them. ${ }^{51}$ Could we say the same thing about meaning? At any rate, once he gains this insight he is no longer tempted by suicide or by Christian and existentialist hopes. He comes to understand that the flat denial of meaning is as empty as the extravagant hopes that people create to answer it. Both are fictions, and both relieve him of the "weight of [his] life," his substance. ${ }^{52}$ It is not surprising that only after escaping them both does he begin to hear the "myriad wondering little voices of the earth rise up."

In The Rebel Camus' concern about this loss of substance and the apocalyptic 
Ph.D. Thesis - R. Srigley McMaster - Religious Studies character of modernity shifts from private matters to public ones. Apocalyptic aspirations also have political consequences. These consequences are the focus of Camus' post-war books, particularly The Plague and The Rebel. The perfection sought by modern revolutionaries proved deadly for those deemed unworthy or unwilling to participate in their project. Take any modern revolution you please, the French, the Russian, the Chinese, or even one of the more recent efforts in Cambodia or Rwanda. In each case political dissent of any kind, and often not even dissent but merely membership in the wrong social or racial group, meant either the concentration camp or summary execution. Freedom from nature meant freedom from the constraints of human nature, too. Camus describes the camps as experiments designed to test the extent of that freedom by determining the malleability of human nature. ${ }^{54}$ Without nature to guide them human beings become raw material in the same sense as the metals we take from the ground or the trees we cut from the forest. They are simply neutral matter, completely open to any form of manipulation deemed necessary by the latest political program.

In the absence of natural limits the scope of human action was greatly expanded because there was virtually nothing to stand in its way, no objective reality and no subjective one either. The modern loss of substance was preeminently a loss of moral substance, though we need not explain that loss moralistically. It is probably true that at some basic level modern people long ago simply decided in favour of themselves and their own satisfactions in preference to the fateful and terrible encounter with the world 
Ph.D. Thesis - R. Srigley McMaster - Religious Studies that was teaching of the ancients. Yet there have also been changes in modernity that have encouraged this disposition to occupy a greater portion of the human psyche than one might otherwise expect. A substanceless world on the objective side encourages a substanceless response on the subjective side. Though the process is ultimately a mystery, it is arguable that the better part of human virtue is achieved and cultivated through an encounter with the hard though purposeful movements of a world not of our own making. This world is hard, beautiful, often joyous, but always tragic. The cardinal virtues of the ancients - wisdom, courage, moderation, and justice - are not moral rules in the narrow sense but insights culled from the history of our relationship to that world and of the human effort be equal to or to cope with it.

Now what good are such virtues in a world that has no purpose or substance? What is the use of courage when there is nothing left to fear? What is the use of moderation when one is told daily that there are no longer any boundaries or limits and this is proven practically in a hundred different ways? The entire moral edifice of the ancient world begins to collapse from neglect and misuse on a massive social scale. Calling for limits in a world that has lost all contact with real things is like trying to teach Plato to undergraduates: "I mean, why doesn't that guy just, like, chill?" Yet in essays like The Rebel, "Helen's Exile," "Prometheus in the Underworld," and the Preface to his Algerian reports in Actuelles III Camus repeatedly does just that. Ultimately to no avail. In "Helen's Exile" he writes: 
Ph.D. Thesis - R. Srigley McMaster - Religious Studies

In our madness we push back the eternal limits, and at once dark Furies swoop down upon us to destroy. Nemesis, goddess of moderation, not of vengeance, is watching. She chastises, ruthlessly, all those who go beyond the limit... We, who have thrown both the universe and mind out of orbit, find such threats amusing. In a drunken sky we ignite the suns that suit us. ${ }^{55}$

Apocalyptic accounts are total accounts; and total accounts are total precisely because they do not permit the existence of anything that would cause a "fissure in the totality." Anything that transcends or exceeds the apocalyptic dream world must be either distorted to fit the narrative or destroyed. Because all apocalyptic accounts are also utopian, the feature that is always missing from them is the tragic in existence. We do not see the hard and tragic things because we do not want to see them. But since tragic things do happen, they have to be reinterpreted in order to confirm the narrative and ensure a happy outcome. This does not mean that the perfection of these utopian accounts entails the complete absence of evil. In the final apocalyptic kingdom, perhaps. But in this type of literature evil enemies and powers abound and are usually far fiercer and more demonic than anything we find in the literature of the ancient world. ${ }^{57}$ Their exaggerated malevolence should not mislead us into thinking that they make for tragedy in the sense that Camus understands it, however. In the apocalypse evil serves the good just as surely as do its supporters. There is never any true breach, never a real failure or success, and the hard edge of reality is never encountered. Even the worst things that happen are somehow part of the providential plan, and that plan is fixed, like the outcome of a prime time sitcom or the average political debate. ${ }^{58}$ In this world not only do things miraculously 
Ph.D. Thesis - R. Srigley McMaster - Religious Studies become their opposite, ${ }^{59}$ nothing ever really happens, which explains the profound boredom that underlies even modernity's most violent and excessive enthusiasms. ${ }^{60}$

A common way of responding critically to the totalitarian character of modernity is to offer a non-totalizing account that emphasizes difference, promotes uncertainty, and deconstructs hegemonies. Broadly speaking that is the postmodern critique of modernity. It is a critique that has certain resonances with aspects of Camus' own analysis, particularly with the methodology of the cyclical books. ${ }^{61}$ In The Myth of Sisyphus Camus critiques the excessive eschatological hopes of Christians and existentialists not by trying to formulate the right kind of eschatological hope, but by recommending something akin to hopelessness - the absurd. It is, of course, Camus' absurd - not meaninglessness per se but a divorce from a greater reality. But there is little or nothing to be hoped for here by way of reconciliation, and there is a strong suggestion that the modern obsession with meanings of that order is itself the real problem. "I understand now why the doctrines that explain everything to me also debilitate me at the same time. They relieve me of the weight of my own life and yet I must carry it alone." Total meanings - "doctrines that explain everything" - may somehow satisfy, but they have their price. They rob our lives of meaning - "weight," to use Camus' word. And since total meaning provokes feelings of meaninglessness, total meaningless seems preferable: "It was previously a question of finding out whether or not life had to have a meaning to be lived. It now becomes clear 
Ph.D. Thesis - R. Srigley McMaster - Religious Studies that it will be lived all the better if it has no meaning. ${ }^{963}$ This is not nihilism, despite its excessive formulation. But it is close. It is something like tough or honourable pessimism offered as an antidote for our penchant for dishonest and extravagant hopes and meanings.

Camus employs a similar strategy in The Rebel. He does not try to supercede the alleged perfection of modern revolutionary movements by offering a superior account of order, but by exposing that perfection as fraudulent through the example his own and others' rebellion and by arguing that there is no justification, historical or otherwise, to think that the need for such acts will ever be eliminated. Not perfection then but an insuperable struggle with imperfection and injustice; not the right kind of meaning or hope but a world without meaning and hope. To modernity's excesses - its totalities Camus responds by creating as many fissures as he can and by showing us that less really is more.

This is not Camus' best response to modernity. I think there are two reasons why it is inadequate. The first reason is substantial. It might be true in a general way that indeterminacy, uncertainty, and meaninglessness are constant features of human life. But they are not the only features. There are many things about which most of us are pretty certain, and there are events in life that are so pregnant with meaning that we usually do what we can to avoid them. To consider these post-modern offerings in abstraction from the full range of human experience distorts whatever sense they do have and creates an 
Ph.D. Thesis - R. Srigley McMaster - Religious Studies image of life that is unbalanced and thus unfaithful to the original. It is no doubt true that playful nihilism of this sort is less violent and menacing than the totalitarian nihilism it seeks to replace. But its playfulness is not the same thing as wisdom in the ancient sense and seems ill-equipped to deal those nihilists who are not playful or with the normal host of violent aggressors with whom we are confronted daily in the contemporary world.

The second reason that such "postmodern" responses to the excesses of modernity are inadequate is evident in a peculiar pattern that emerges in Camus' cyclical books, and that might also characterize a good deal of postmodernity itself. To make the point simply, the complete denial of meaning is just as much a totality as the total meanings it claims to deconstruct, appearances to the contrary notwithstanding. And because one good totality deserves another, the broken or deconstructed version inevitably leads back to its antithesis as the necessary solution to its total denial of meaning. Not immediately, of course. Playful nihilism is often very enjoyable, and can be experienced as liberating and fulfilling in comparison to the totalitarian nihilism that has been left behind. But because this shift does not entail any real change of disposition, a totality is still what one really wants - something extreme, something apocalyptic, something intense. The only difference nowadays is that this totality also has to be safe (and preferably virtual) in accordance with the dictates our postmodern utopian sensibilities. ${ }^{64}$

In Camus' case this movement or pattern is manifest in a number of ways. Although most of these ways employ explicitly Christian language, they illuminate the 
Ph.D. Thesis - R. Srigley McMaster - Religious Studies character of all forms of totalitarian thinking. In The Rebel Camus says that because God is the source of the injustice in the world, he is the antithesis of the movement of rebellion; ${ }^{65}$ but he also argues that because it is impossible to imagine any meaningful sense of justice apart from some divine source, rebellion cannot get along without one, and God turns out to be necessary after all. ${ }^{66}$ The same type of contradiction occurs in the case of values. Camus claims that transcendent or formal values are oppressive or totalizing because they do not account for the concrete movements of history. ${ }^{67}$ But he also says that once such values are rejected, all that remains are these movements, which in the absence of any form of transcendence are both valueless and total. ${ }^{68}$ The reason for these contradictions lies in the antithetical structure itself. Each pole of the antithesis is inherently unstable because it lacks things the other pole claims to possess exclusively but which are essential aspects of human nature. Moreover, the habit of thinking in terms of such totalities leads us to believe that any answer that does not share their totalizing structure must be inadequate. All of these factors conspire to send Camus shuttling awkwardly back and forth between the various antithetical pairs that form so much of the argument of The Rebel: God or the world, formal values or creative values, nature or history, and even the absurd or rebellion. They are all false problems and intellectual dead ends. Yet they had for Camus a measure of credibility because they were part of the climate of opinion in France at the time and because they reflected accurately the selfunderstanding of many of the participants in the debate, both past and present. How 
Ph.D. Thesis - R. Srigley McMaster - Religious Studies tempting to frame the moral crisis of the twentieth century in terms of the transcendence/immanence distinction when almost everyone who was party to the argument, whether for or against, understood it in that way.

As early as 1946 Camus understood that this "postmodern" style of response to modernity was bankrupt and he was willing to say so publically. In his Notebooks there is a report of a conversation with Sartre, Sperber, Koestler, and Malraux in which Camus abandons the kinds of concessions described above and states his criticism of modernity and his own positive recommendations simply and straightforwardly. In response to Koestler's proposal to formulate a "minimum political code of ethics" and to abandon "false scruples" like "soul-searching" and worrying about who might misuse your words and for what purpose, Camus offers this reply: "Don't you believe that we are all responsible for the absence of values? And that if all of us who come from Nietzscheism, from nihilism, or from historical realism said in public that we were wrong and that there are moral values and that in the future we shall do the necessary to establish and illuminate them, don't you believe this would be the beginning of a hope?'69 This is a remarkable statement. In the present company it did not receive much support. But it was an extraordinarily honest and frank thing to say nonetheless, and it is typical of a sentiment or idea that runs throughout Camus' books and that also forms part of his corpus. Camus has moments of utter clarity about the nature of the modern predicament that are almost completely free of both modern and Christian assumptions. 
Ph.D. Thesis - R. Srigley McMaster - Religious Studies Sometimes these insights are found in Camus' cyclical books, but more often they are apparent in his shorter lyrical essays. In both instances there is an acuity of insight and a depth and freedom in Camus' description of human affairs that distinguishes them from the general tone and direction of the cyclical books. We could say that these insights are better than what we find in the cyclical works generally, so long as the meaning of better is clear: they are better in the same way that reading a fine book while sitting on the shore of a Northern Ontario lake is better than fixing a sump pump or plugged sink on a hot summer day in the city. The one type of activity engages more of our human capacities and it does so more finely than the others, but both are absolutely necessary to the care of one's own. In his cyclical books Camus does the dirty work of analysis, as it were. In the following pages I will explore this odd character of Camus' writing and try to explain the different levels or types of insight apparent in his books in relation to the structure and organization of his work as a whole.

By the mid-forties Camus had begun to speak about his books as being organized according to different stages or cycles. The first draft of that organization appears in his notebooks in 1947 , just shortly after the publication of The Plague. ${ }^{70}$ Camus continued to refine and nuance its formulation well into the fifties. The last version we have occurs in Carnets III and was written in $1955 .^{71}$ The version to which most commentators refer when discussing this aspect of Camus' work is usually a synthesis of two separate 
Ph.D. Thesis - R. Srigley McMaster - Religious Studies versions. The 1950 version found in Notebooks 1942-1951 uses a familiar triptych of Greek myths as its organizing principle. "I. The Myth of Sisyphus (absurd) - II. The Myth of Prometheus (revolt) - III. The Myth of Nemesis. 1951."72 The final 1955 version does not change this one substantially; it completes it by supplying the governing theme missing from the Nemesis cycle - love - and by adding an intermediate stage between the second and third cycles that appears to be Camus' attempt to account for The Fall and the collection of short stories later published as Exile and the Kingdom on which he was working at the time..$^{73}$

Though this organization evolved over time and certain details changed as Camus' insight into the nature of the work matured, there is nonetheless a remarkable continuity in the project. The cycles themselves are constant substantially if not formally, as are their organizing themes. And the books that Camus wrote and proposed to write match them perfectly. ${ }^{74}$ Moreover, the general aim of the cyclical books seems to have remained constant from conception to completion. Their principal content is an analysis and critical assessment of the nature of modernity's apocalyptic aspirations and an exploration of their origins. The Greeks form part of that content too. But in the cyclical books they are present mainly in the critical posture of the analyses and as a kind of measure or standard of moderation to which Camus often alludes but which he rarely explains in detail. ${ }^{75} \mathrm{I}$ think this allusive presence was both intentional and required by Camus' method as he understood it. The cyclical books are an attempt to think modernity 
Ph.D. Thesis - R. Srigley McMaster - Religious Studies through to its end in order to clear away its confusions and excesses and make a renewed and unprejudiced reading of the Greeks possible once again. That is their ultimate aim. ${ }^{76}$ But many things stood in the way of its fulfillment, principally the modern intellectual dispositions and dangerous political and social structures that Camus diagnosed in himself and his contemporaries. For Camus these things had to be understood and overcome before any real progress regarding the Greeks would be possible. ${ }^{77}$

This is not how the cyclical books are usually read. As we have seen, most commentators interpret Camus as a disaffected modern whose aspirations run in a number of different directions depending on the commentator's individual preference: to Christianity, to an earlier and truer dispensation of the modern project itself, and sometimes even to post-modernity. It seems that all the possibilities have been explored save for the Greeks. And even when some daring commentator breaks rank and ventures to explore Camus' Hellenism on its own terms, the results are often less than brilliant, either because Camus' best insights are neutralized by the commentator's judgement of the Greeks' inferiority in comparison to his own preferred tradition, or because those insights are deemed to be unscholarly and sophomoric. ${ }^{78}$

My interpretation of the cyclical books also differs how they are usually read with regard to their organization and structure. The most common type of reading is what I call the chronological interpretation. Its two main claims are that the progression of the cycles is best understood as straightforward development and that this development is equivalent 
Ph.D. Thesis - R. Srigley McMaster - Religious Studies to Camus' own, that is to say, the cyclical books are autobiographical. ${ }^{79}$ Its account of the substance of that development is something like the following, though there are many variations in detail. ${ }^{80}$ Camus started out as a natural man, enamoured of the sun and the delights of the Mediterranean, but essentially unreflective about his own place in the world (The Wrong Side and the Right Side, Nuptials). ${ }^{81}$ That natural, sentimental, and unreflective delight in existence was shattered by his discovery of the absurd (The Myth of Sisyphus, The Stranger, Caligula).$^{82}$ Now nature and its joys were nothing more than a lost paradise. Camus then had to set about creating his own values in a world that had suddenly been divested of meaning. Faced with an empty nature and a bellicose political world, Camus turned to history as a new source of value (The Rebel, The Plague, The $J u s t){ }^{83}$ His failure lay only in the fact that he refused or was unable to follow that movement to its logical conclusion. Though rightly critical of the excesses of the revolutionary movements of the twentieth century, Camus failed to understand and appreciate the original values that had inspired them: the historicist notion of human selfcreation through time. ${ }^{84}$ In default of such creative values, Camus was caught, unwilling to accept history but no longer able to return to nature. As a stop gap measure, he turned nostalgically to the unreflective natural world of his youth. Given the content of The First Man, that return was Camus' position at his death. According to the chronological interpretation, we simply do not know whether he would have overcome it (again) and resolved the dilemma or continued on in the same manner. 
Ph.D. Thesis - R. Srigley McMaster - Religious Studies

Though a familiar story and consistent with modernity's own self understanding, the chronological interpretation is an ideological construct that does not tally with the facts. I explore this matter in greater detail in the conclusion of this work, but for now I can mention a few objections that will also help to clarify my own argument regarding the cycles. Camus' earliest books - The Wrong Side and the Right Side and Nuptials - are neither sentimental nor unreflective. It is true that they are absolutely suffuse with a sense of love for the world and its inhabitants, but that love is utterly clear-sighted and far less susceptible to the easy modern and Christian consolations that are sometimes apparent in later books. ${ }^{85}$ These early books are highly reflective about the world's order and its ultimately tragic character. But what is remarkable about them is that their tragic awareness never overwhelms or defeats Camus' erotic attachments or crushes his desire to see life as it is and to live it fully. ${ }^{86}$ No feature of life is distorted or masked to serve an ideological agenda and Camus remains radically open to all that life offers, including experiences like the absurd and rebellion. This raises yet another objection to the common reading of the cycles.

All the experiences that were to mark Camus' later development according to the chronological interpretation are present here in his very first books, and are often discussed far more authoritatively than they are in subsequent works. In "The Wind at Djemila " and "Summer in Algiers" he describes the experience of the absurd poignantly and compellingly but without falling prey to the metaphysical confusions and excesses 
Ph.D. Thesis - R. Srigley McMaster - Religious Studies occasionally found in The Myth of Sisyphus; and in "The Desert" though he is tempted by something like metaphysical rebellion, he never takes that temptation as the only thing he has to go on or as in any way exhaustive of his experience of life, as he sometimes does in The Rebel. ${ }^{87}$ In neither instance does he accept the experience doctrinally and then attempt to think about it within those parameters. He simply thinks about it, which in large part means thinking about it in relation to the many other things he experiences. ${ }^{88}$

There are two additional objections to the chronological interpretation I want to discuss briefly before describing the argument of this thesis. The first objection is that the cyclical books are not in fact autobiographical. There is plenty of textual and extra-textual evidence to support this argument. In the opening pages of The Rebel Camus says explicitly that his task in the book is to explore a pathology that is prevalent in his time, not in his own life. ${ }^{89}$ Of course he suffers from that pathology too by virtue of his participation in his time. But that is not the same thing as saying that the experience somehow matches his own intellectual development. The same sort of proviso is present in The Myth of Sisyphus, ${ }^{90}$ but it seems to have been even less successful in discouraging this type of autobiographical reading than the one Camus offers in The Rebel. In 1950 Camus devoted an entire essay to debunking the idea that he ever was the absurd man as well as the autobiographical assumption itself. It is worth quoting the passage in full.

A man's works often retrace the story of his nostalgias or his temptations, practically never his own history especially when they claim to be autobiographical... As far as such a thing is possible, I should like to have been an 
Ph.D. Thesis - R. Srigley McMaster - Religious Studies

objective writer. What I call an objective writer is one who chooses his themes without ever taking himself as the subject matter. But the modern mania of identifying the author with his subject matter will not allow him this relative creative liberty. Thus does one become a prophet of the absurd. Yet what else have I done except reason about an idea I discovered in the streets of my time? ${ }^{91}$

The autobiographical assumption ignores the evidence of the texts and Camus' own published remarks about his aim in writing them and by doing so circumvents the most basic question of interpretation - what is this book about? - by assuming that it has already been answered.

My final objection to the chronological interpretation is that its claim that the thematic progression of the cycles is one of straightforward improvement is not faithful to the content of the books. One of the facts consistently overlooked by commentators who endorse this interpretation is that as the cycles progress the phenomena they describe become worse, not better. Whatever else one may say about the absurd, its sense of meaninglessness is pretty mild stuff compared to the cataclysmic violence of the revolutionary movements Camus analyses in The Rebel. And those political movements pale by comparison to the completely unvarnished account of modernity's aspirations that Camus offers in The Fall. As Camus says in the epigraph to the latter text, Jean-Baptiste Clamence embodies "the aggregate of vices of our whole generation in their fullest expression. ${ }^{.92}$ In this book Camus refuses to concede any ground to modernity's usual apologetics and does not allow himself to be diverted by arguments that posit a common ground or plead extenuating circumstances for its criminal excesses because they are 
Ph.D. Thesis - R. Srigley McMaster - Religious Studies somehow the result of an over-zealous desire for justice. ${ }^{93}$ Here Camus abandons all such concessions and instead ruthlessly exposes the self-love that he claims is modernity's real existential source and something far worse than even its most oppressive totalitarian regimes. ${ }^{94}$ Jean-Baptiste Clamence is an admirer of the Nazis' methodological extermination of the Jews. But he himself is after even bigger game than that and pursue even sweeter "dreams of oppression." 95 This is something even worse than the absurd and rebellion.

It is time for a new reading of Camus. We need an interpretation that better accounts for the nature of his project and the substance and organization of his books, and that does not suffer from the kinds of confusions and contradictions apparent in the Christian, modern, and chronological interpretations I have discussed in the preceding pages. The proper context for such an undertaking is Camus' entire corpus. Camus' books were carefully planned and form part of a larger structure that is highly organized but whose meaning is not immediately apparent. Such an interpretation need not include all the journalism, but it should include a significant number of the cyclical books, several early works that predate the cyclical structure entirely (The Wrong Side and the Right Side and Nuptials), and a number of later "lyrical" essays that were written at the same time as the cyclical books but that do not match their analyses methodologically or substantially. ${ }^{96}$ Only an analysis of that scope would do justice to Camus' achievement 
Ph.D. Thesis - R. Srigley McMaster - Religious Studies and bring to light the extraordinary nature of his corpus.

Such an undertaking is too great for one book, and perhaps even for one writer. But that should not be a deterrent. Great projects always begin somewhere. In the pages that follow I offer a first installment on that project by interpreting a representative sample of cyclical and non-cyclical books in order to explore Camus' critique of modernity and Christianity and to shed some light on the formal structures of his books to which I have alluded. I will also say a few things about Camus' Greeks and how they afforded him a way out of the confusions and excesses of modernity. The particular books I will examine are The Myth of Sisyphus, The Rebel, The Fall, and The First Man. I explain my choice of these texts and the structure of my argument in what follows.

First the essays. The Myth of Sisyphus and The Rebel are both histories, though commentators rarely comment on the fact. Their analyses are structured in two different but related ways. First there is the historical dimension proper. Both books attempt to discover the nature of modernity through an analysis of its historical origins and influences. But these historical analyses are also guided and organized thematically. The Myth of Sisyphus begins not with modernity per se but with one of its current manifestations - the absurd - an experience of meaninglessness that had become prevalent in the postwar period. The same is true of The Rebel. It explores the nature of modernity almost exclusively from the standpoint of the experience of rebellion. The thematic and historical dimensions of Camus' histories are parts of his larger effort to 
Ph.D. Thesis - R. Srigley McMaster - Religious Studies

uncover the nature of modernity. Both dimensions suffer from the limitations of the cyclical books generally, but they do so in different ways. I will discuss the historical dimension of these books first, and then turn to the question of their thematic organization.

When read alongside one another The Myth of Sisyphus and The Rebel reveal a pattern of research in which each new installment pushes the analysis further back historically in search of the origins of modernity and its own organizing experience. The absurd was a sentiment that prevailed in 1920 s and ' 30 s and was apparent in the writings of people like Martin Heidegger and Jean Paul Sartre. Camus discusses these writers but his analysis does not end with them. It also reaches back into the middle to late nineteenth century in order to explore, however briefly, the works of some of the first great critics of modernity - Nietzsche, Kierkegaard, and Dostoevsky. The same movement is apparent in The Rebel, though here the scope of the analysis is greater and extends even further back historically. The revolutionary movements with which the book begins were contemporary or near contemporary with its publication. But in his search for the origins of these movements, Camus goes back to the German and French theorists of the early to middle eighteenth century - Hegel and Rousseau primarily - who first gave expression to those ambitions. With The Rebel Camus had arrived at the foundations of modernity. But what had he learned as a result?

Between The Myth of Sisyphus and The Rebel Camus had covered some two 
Ph.D. Thesis - R. Srigley McMaster - Religious Studies hundred years of contemporary history, yet his attempt to discover the origins of modernity had been unsuccessful. Both books failed, partly because of the normal limitations of any historical inquiry, partly because Camus discovered in the process of writing them (or was this too part of the plan?) that the source of the modern apocalyptic urges he was tracking lay further back historically that he had originally assumed. Even before finishing The Rebel Camus seems to have understood the limitations of the project as well as the need for another historical analysis to complete it. What he could not find through an exploration of modernity itself, he now says he will find through a return to a period of ancient history he had explored briefly in The Rebel and to which he had devoted an entire thesis some twenty five years earlier during his university days in Algeria. "97 "Go back to the passage from Hellenism to Christianity, the true and only turning point in history." 98 To overcome modern nihilism it would not be enough to return to Christianity, because Christianity was itself implicated in the modern project as an earlier dispensation of the same existential orientation. ${ }^{99}$ The only way to free himself entirely from modernity and its antecedents and to achieve a measure of spiritual or intellectual health was to make his way back to the Greeks and to understand them as they would have understood themselves, without our modern and Christian preoccupations and anxieties.

This shift toward the ancient world was a significant change in the orientation of Camus' histories. The methodological restriction of his analyses to the modern period 
Ph.D. Thesis - R. Srigley McMaster - Religious Studies alone had failed to produce results because modernity's true origins lay further in the past than the method would allow. Moreover, the analyses themselves kept on turning up findings that violated the intellectual assumptions behind the methodology by implicating Christianity in the modern project in a way that Camus was for some reason unwilling to admit publically at this stage. ${ }^{100}$ After The Rebel that changes. Something breaks in the analysis and Camus no longer seems willing to make apologies or to side step these questions. He states his opposition to Christianity explicitly and announces that a critical study of its teachings and of the manner in which they depart from those of the Greeks will be the subject of his next history, The Myth of Nemesis. ${ }^{101}$ What is important to note here is that the proposed subject of Nemesis is also the subject of Christian Metaphysics and Neoplatonism, Camus' first book length essay. ${ }^{102}$ If we consider this common theme together with the changes in content and mood of the post-rebellion writings, it is a safe bet to say that Camus' last cycle of books would have departed significantly from the pattern of the previous two cycles, and that it would have done so precisely by abandoning the modern assumptions and methods on which those cycles rested and by return substantially to the types of insights he had first explored in his earliest writings, Christian Metaphysics and Neoplatonism, The Wrong Side and the Right Side, and Nuptials. Camus' makes his intention to return these works amply clear in a variety of places, but nowhere more so than in his 1958 Preface to The Wrong Side and the Right Side: 
Ph.D. Thesis - R. Srigley McMaster - Religious Studies

Someday, when a balance is established between what I am and what I say, perhaps then, and I scarcely dare write it, I shall be able to construct the work I dream of. What I have tried to say here is that in one way or another it will be like The Wrong Side and the Right Side and that it will speak of a certain form of love. ${ }^{103}$

And even more forcefully: "If, in spite of so many efforts to create a language to bring myths to life, I never manage to rewrite The Wrong Side and the Right Side, I shall have achieved nothing."104

The same types of problems and changes are apparent in the thematic organization of the histories. Camus orders each history according to the theme of the cycle to which it belongs. In principle this type of thematic limitation need not be a problem, though it might cause an author to overlook or omit important matters that do not fall easily within the scope of his chosen theme. The justification Camus offers for employing this approach is that the experiences he selects as his themes are those that in large part define the modern world he lives in and more particularly its apocalyptic ambitions. ${ }^{105}$ The method works well enough with regard to a limited range of modern phenomena. But it begins to break down in a way that mirrors the breakdown of the historical analyses proper the closer Camus gets to the question of the nature of modernity itself. That breakdown reaches its apex after the publication of The Rebel, when the cyclical books grind to halt, including the histories. Camus continued to plan these works and to outline their construction, but he effectively stopped writing them. During the next nine years he would not publish a single new cyclical book, and for the next five years he would not 
Ph.D. Thesis - R. Srigley McMaster - Religious Studies

publish a book of any kind. ${ }^{106}$

In part Camus' silence may have been fall out from his public quarrel with Sartre in 1952. Several authors have suggested this explanation. ${ }^{107}$ Perhaps. But only in part. I think there was something far greater at stake in this silence than the unpleasant consequences of a political battle Camus had already won substantially, though he may have lost it on the level of French public opinion. ${ }^{108}$ There were difficulties with The Rebel, but they were not the ones Sartre imagined. They were inherent in the structure of the cyclical books themselves. I think Camus began to realize that the methodology and the intellectual assumptions on which the cyclical books had been based were unworkable and therefore had to be abandoned entirely if any progress was to be made. Just how much of this change in approach Camus had understood and anticipated from the start of the project and how much of it was a discovery he made along the way is a difficult question to answer. I think both assertions are true in some measure.

There is good evidence that the plan of the cyclical books was from the start to descend into the heart of the modern world in order to understand its nature and to overcome it. That plan or intention implies that Camus knew from the outset that the descent was a descent and that the place to which it led was therefore not exhaustive of reality. It would be followed by an ascent to some better, more existentially satisfying place. I think Camus also understood, in however limited and youthful a way, what it was he wished to ascend to, principally because he had already experienced it, just as he 
Ph.D. Thesis - R. Srigley McMaster - Religious Studies believed all people had. But I also think the descent Camus undertook was real, that the modern things he encountered were genuinely confusing and therefore difficult to understand, and that the confusions apparent in his histories are evidence of the fact that at times he too was confused by and implicated in the modern things he was trying to overcome. The following passage from "Return to Tipasa" is vivid expression of this experience:

I live with my family, who believe they reign over rich and hideous cities, built of stones and mists. Day and night it raises its voice, and everything yields beneath it while it bows down to nothing: it is deaf to all secrets. Its power sustains me and yet bores me, and I come to be weary of its cries. But its unhappiness is my own, we are of the same blood. I too am sick, and am I not a noisy accomplice who has cried out among the stones? ${ }^{109}$

Even before the publication of The Rebel and the fight with Sartre there is evidence that Camus felt unduly constrained by his method. In 1951, after completing the first draft of The Rebel and his second cycle of books, he asks: "And now, can creation be free?"110 Free from what? Sometimes Camus speaks about his cyclical books as a man speaks about a job he feels compelled to do out of a sense of duty but for which he has little stomach. As the second cycle of books nears completion he speaks increasingly about the limits of his achievements and his inability to speak in his own name. "I And though he recognizes that what lies beyond this "absurd, rebellious" contemporary world of ours is love and compassion in their original sense, he fears he no longer has the innocence necessary for those experiences. ${ }^{12}$ The overriding impression with which these 
Ph.D. Thesis - R. Srigley McMaster - Religious Studies remarks leave the reader is one of frustration and dissatisfaction, but also a sense that the third cycle of books would be a vastly different undertaking from the first two. And so it is. ${ }^{113}$ But first the significance of this new orientation.

To state its meaning simply, I would say that the cyclical books became unworkable because their method was flawed and because that flaw entailed or encouraged a substantial confusion that distorted Camus' findings. Together these problems made the completion of the project as originally conceived highly unlikely because they ensured that its method was constantly working against its most basic positive aims. ${ }^{114}$ Camus' principal aim in writing these books was to assess the modern project critically and to discover a genuine alternative to it. But his method guaranteed that even his best critical insights would never be entirely free of modern assumptions and thus would continue to compromise his effort fundamentally. So long as he remained true to that method, even his most devastating critical analyses of modernity's apocalyptic fury left an ember of that fury smoldering in the ashes of its apparent destruction. ${ }^{115}$ As to content, what Camus seems to have discovered is that modern apocalyptic excesses and the host of secondary experiences that attend them are not corruptions of essentially true and moderate ambitions and therefore do not themselves lead to more reasonable or moderate accounts, even if subject to critical analysis. ${ }^{116}$ Such excesses do not have the same source as more moderate responses. They are the fruit of a different sort of human disposition. In the end the only way to overcome these dispositions is simply to abandon 
Ph.D. Thesis - R. Srigley McMaster - Religious Studies them. ${ }^{117}$ Critically what is required is an analysis of that disposition that brings to light the true character of its apocalyptic aspirations and that does not concede any ground to the common origins argument, which exempts those aspirations from critical reflection because it accepts them as permanent features of human nature. That analysis is precisely what Camus accomplishes in The Fall.

The Fall is part of an intermediate stage of works that lies between the cycles of rebellion and love. ${ }^{118}$ It is similar to the cyclical books in that it attempts to uncover the nature of modernity. But it does so in a way that breaks fundamentally with their methodology and thus is something like a first expression of the new orientation I have been describing. There is no fidgeting here. Camus makes no concessions to modern ambitions nor does he attempt to rescue modernity from its own worst excesses by trying to tease some type of pre-modern moderation out of them. Apocalyptic aspirations are a pathological form of self-love. ${ }^{119}$ Period. That self-love is swollen to such a degree that it cannot see anything in the cosmos but its own interest. Its highest aspiration is the destruction of all existing things insofar as they might detract from its enjoyment of itself and create obligations that would limit the satisfaction of its desire. ${ }^{120}$ In short, it is a selflove that seeks the destruction of all erotic attachments save one, and that is not really an attachment but an obsession that conduces toward a sort of final emptiness. Not completely, of course. Camus' analysis is remarkably astute in that even as he explores the darkest aspirations of the modern project he never loses sight of the fact that these 
Ph.D. Thesis - R. Srigley McMaster - Religious Studies aspirations are illusory and hence unsatisfiable. Apocalyptic aspirations do not change reality - they destroy it. And the consequences of that destruction for the one who sees it though to the end is the type of madness from which we see Jean-Baptiste Clamence suffer in the final pages of the book. ${ }^{121}$

As indicated by the book's epigraph, The Fall offers only a negative snapshot of reality. It attempts to describe the worst human disposition as it is manifest across an entire generation in its fullest expression. ${ }^{122}$ This is a significant limitation, but it is not of the same type of limitation that is apparent in The Myth of Sisyphus and The Rebel. As we have seen, these earlier books are unsuccessful largely because modernity's central ambition cannot be reached by an analysis of the absurd and rebellion alone. That ambition is not exhausted by these experiences. Not so in the case of love. Camus' choice of love as the principal ordering theme of The Fall allows him to talk about everything he needs to talk about in order to complete the descriptive and critically analysis of modernity that was his principal goal. What he does not manage to do in this book is to offer either a positive account of Greeks or to explain how a return to them would also entail an renewal of eros in its best and fullest sense. There are hints of these things in The Fall, but no complete analysis. That is the job of The First Man. The First Man is a new dispensation for Camus. It is his first attempt to offer the positive image of human nature lacking from The Fall and it occurs in the clearing created by the latter's critical work. The title of the books mirrors its content and is instructive as to its meaning. The 
Ph.D. Thesis - R. Srigley McMaster - Religious Studies cyclical essays move backward historically in their search for the origins of modernity and their attempt to discover an alternative to it. ${ }^{123}$ If we couple that movement with the religious image Camus draws on for the title of his third novel, we can say that before the fall in the Christian sense there is the first man, le premier homme. But Camus changes the beginning so as to get it right this time, just as he changed the nature of its corruption in The Fall. The first man is not a Christian, but a Greek and perhaps also a Jew. ${ }^{124}$ Le premier homme is an image of human nature healed of our apocalyptic madness, but on this side of that madness. It is The Wrong Side and the Right Side and Nuptials rewritten after having lived through the nightmare of modernity.

This thesis is an analysis of Camus' histories. It is also an analysis of two late fictional works (The Fall and The First Man) that help us to complete the findings of those histories in a way that Camus' earlier novels and plays do not. My analysis of these books has two aims: to explain the organization of Camus' books and the changes of orientation I have discussed above, and to examine his critique of modernity and Christianity and his attempt to restore the Greeks. Camus understood the apocalyptic aspirations that drive the modern world and encourage its worst excesses and violence. But he was also one of the few critics of modernity to explore those aspirations historically and to offer us an image of the world in which they were still understood as possibilities and not yet as nature. That image alone, no matter how fleeting and 
Ph.D. Thesis - R. Srigley McMaster - Religious Studies incomplete it may have been, is reason enough for us to read Camus' books attentively and to explore his critique of modernity seriously. 
Ph.D. Thesis - R. Srigley McMaster - Religious Studies

Notes

1. Albert Camus, Notebooks 1942-1951, trans. Justin O'Brien (New York: Paragon House, 1991), 183.

2. Ibid., 267.

3. Albert Camus, Carnets III: Mars 1951-Décembre 1959 (Paris: Gallimard, 1989), 209.

4. Ibid., 220.

5. Albert Camus, The Rebel, trans. Anthony Bower (New York: Vintage International, 1991), 218.

6. Albert Camus, Notebooks 1942-1951, 13. This insight is repeated in "Helen's Exile," an essay that appeared in 1948. "Ulysses, on Calypso's island, is given the choice between immortality and the land of his fathers. He chooses this earth, and death with it. Such simple greatness is foreign to our minds today." Albert Camus, "Helen's Exile," in Lyrical and Critical Essays, ed. Philip Thody, trans. Ellen Conroy Kennedy (New York: Vintage Books, 1970), 152.

7. Albert Camus, Notebooks 1935-1942, trans. Philip Thody (New York: Paragon House, 1991), 28-29, 36, 79-80, 102-103, 196-197, 206-211. Notebooks 1942-1951, 5, 7, 13, 128, 183, 188, 197, 249, 257, 260, 263, 267. Carnets III: Mars 1951-Décembre 1959, 15, 44, 78, 81, 87, 89, 110, 130, 159, 181, 187, 190, 207, 209, 264, 274.

8. Eric Voegelin, Anamnesis, trans. Gerhart Niemeyer (Columbia: The University of Missouri Press, 1978), 190.

9. Albert Camus, Notebooks 1942-1951, 257.

10. Two of the best of these readers are Eric Voegelin and Thomas Merton. I discuss their interpretations below.

11. Bernard Murchland, "The Dark Night Before the Coming of Grace," in Camus: $A$ Collection of Critical Essays (Englewood Cliffs: Prentice Hall, 1962), 67-68.

12. Albert Camus, Lyrical and Critical Essays, ed. Philip Thody, trans. Ellen Conroy Kennedy (New York: Vintage Books, 1970), 320. 
Ph.D. Thesis - R. Srigley McMaster - Religious Studies

13. Camus made the remark during an interview with Jean-Claude Brisville in 1959. It was later published in French in Brisville's La Bibliothèque idéale and in English in Lyrical and Critical Essays, 357-365. In the original version Camus says only a "sense of the sacred." The word "natural" is added by Onimus for interpretive purposes, it would seem.

14. Jean Onimus, Albert Camus and Christianity, trans. Emmett Parker (Alabama: The University of Alabama Press, 1970), 5, 105-106.

15. David Sprintzen, Camus: A Critical Examination (Philadelphia: Temple University Press, 1988), 275.

16. Ibid., 277.

17. "No, I am not an existentialist. Sartre and I are always surprised to see our names linked...Sartre is an existentialist, and the only book of ideas I have published, The Myth of Sisyphus, was directed against the so-called existentialist philosophers." An interview with Jeanine Delpech, in Les Nouvelles littéraires, from Albert Camus, Lyrical and Critical Essays, 345. There is evidence of similar critical analysis in Camus' review of La Nausée in Ibid., 199-202.

18. Sprintzen, Camus: A Critical Examination, 278. "[Camus'] sociological myopia is thus grounded in a bourgeois individualism that it often feels obliged to defend in terms of an ill-defined and sometimes substantialized conception of human nature." And again: "As the world of Algeria was drawn into the historical processes that were the developing European drama-owing in part at least to capitalist expansion, imperialism, and colonialism-making the refuge of Algeria increasingly a matter of historical nostalgia, so the nature nurtured at the roots of Camus' vision is itself being molded and shaped by the forces of history" (276).

19. André-A. Devaux, "Albert Camus : Le christianisme et l'hellénisme," Nouvelle Revue Luxemboureoise, janvier-avril 1970, 11-30; Bruce Ward, "Prometheus or Cain? Albert Camus' Account of the Western Quest for Justice" Faith and Philosophy, Vol.8, No.2 April 1991, 191-213; Bruce Ward, "Christianity and the Modern Eclipse of Nature: Two Perspectives," Journal of the American Academy of Religion, 63/4, 823-843; Thomas Merton, The Plague: Introduction and Commentary, (New York: The Seabury Press, 1968), 4-41;

20. Albert Camus, Lyrical and Critical Essays, 345. See also Camus' essay “The Enigma" in Ibid., 154-161. 
Ph.D. Thesis - R. Srigley McMaster - Religious Studies

21. See Jeffrey C. Isaac, Arendt, Camus, and Rebellion, (New Haven: Yale University Press, 1992). See particularly Chapter 4: "Revolt and the Foundations of Politics," 105139. See also Ronald Aronson's recent book, Camus and Sartre: The Story of a Friendship and the Quarrel that Ended It (Chicago: The University of Chicago Press, 2004). Aronson writes: "Modern secularism moves toward a nihilistic state of mind because it lacks what Camus regarded as the sole saving insight: that life is absurd, and even though we must rebel, nothing can create order or remove death's sting" (120).

22. On the basis of polls taken at the time and sales data from Gallimard, Germaine Brée has argued that in 1970 Camus was still the most popular writer in France, leading both Sartre and Marx. Germaine Brée, Camus and Sartre: Crisis and Commitment (NewYork: Delta Books, 1972), 43-44.

23. For a recent account of this view, see Tony Judt, The Burden of Responsibility: Blum, Camus, Aron, and the French Twentieth Century (Chicago: The University of Chicago Press, 1998), 94, 121.

24. Jean-Paul Sartre, Situations IV: Portraits (Paris: Gallimard, 1964), 92, 100-101, 108.

25. "Unlike Sartre, Camus was not adept at argumentation; it bored and irritated him." Germaine Brée, Camus and Sartre: Crisis and Commitment (New York: Delta Book, 1972), 35 .

26. Eric Voegelin offered the following comparison of Sartre and Camus: "Excuse my rough words - I don't mean to be disrespectful to the psychological analyses of Sartre (late in L'Etre et le Néant, for example) - but he is a vulgarian and an epigone. He's not interesting. He's not to be compared with Camus; he was a thinker! Sartre is not on that level. Eric Voegelin, Conversations, ed. R. Eric O'Connor (Montreal: Thomas More Institute Papers, 1980), 26.

27. Albert Camus, The Myth of Sisyphus, trans. Justin O'Brien (London: Penguin Books, 1975), 110.

28. The term "immanentization" is take from Eric Voegelin, but it is perfectly consistent with Camus' argument. For an explanation of Voegelin's argument, see Eric Voegelin, The New Science of Politics (Chicago: The University of Chicago Press, 1952). See particularly the chapter "Gnosticism - The Nature of Modernity."

29. William Hamilton, "The Christian, the Saint, and the Rebel: Albert Camus," in Forms of Extremity in the Modern Novel, ed. Nathon A. Scott Jr. (Richmond: John Knox Press, 
Ph.D. Thesis - R. Srigley McMaster - Religious Studies

1965), 68-69.

30. Albert Camus, The Rebel, 191-193.

31. Sartre, Situations $I V, 113$.

32. Ibid., 121.

33. Ibid., 124.

34. Sartre says that "man's number one enemy is man." Ibid., 120

35. Ibid., 113.

36. Oliver Todd, Albert Camus: A Life, trans. Benjamin Ivry (New York: Alfred A. Knopf, 1997), 312.

37. Ronald Aronson, Camus and Sartre: The Story of a Friendship and the Quarrel that Ended It, 153-154.

38. Ibid., 151.

39. Albert Camus, Essais (Paris: Gallimard, 1965), 763.

40. Sartre, Situations $I V, 123-125$. Sartre softens the more virulent aspects of Marx historicism in order to make the argument seem that much more obvious and persuasive: "And Marx has never said that History would have an end. How could he say that? One might as well say that one day man would be without goals. He spoke only of an end to prehistory, that is to say, a goal that would be attained within History itself and surpassed as all goals are" (125).

41. Ibid., 121, 122-123, 113.

42. "You once wrote: 'Secret of my universe: imagine God without the immortality of the soul.' Can you define more exactly what you meant?" "Yes. I have a sense of the sacred and I don't believe in a future life, that's all. Albert Camus, "Replies to Jean-Claude Brisville," Lyrical and Critical Essays, ed. Philip Thody, trans. Ellen Conroy Kennedy (New York: Vintage Books, 1970), 364.

43. This idea can be found expressed throughout The Rebel. Camus articulated a similar account in a lecture on tragedy he delivered in Athens in 1955, later published in Lyrical 
Ph.D. Thesis - R. Srigley McMaster - Religious Studies

and Critical Essays under the title "On the Future of Tragedy." "No tragedies, therefore, will spring from romanticism, but only dramas, and among them, only Kleist's or Schiller's reach true greatness. Man is alone, and thus confronted with nothing but himself. He ceases to be a tragic figure and becomes an adventurer" (306). There is an even earlier expression of the same idea in an essay from 1937, "The New Mediterranean Culture": "There are, before our eyes, realities stronger than we ourselves are. Our ideas will bend and become adapted to them." Ibid., 195. Here Camus links this awareness of a greater or stronger reality with tragedy explicitly. In an even earlier essay from The Wrong Side and the Right Side Camus writes: "For what struck me then was not a world made to man's measure, but one that closed in upon him. If the language of these countries harmonized with what echoed deeply within me, it was not because it answered my questions but because it made them superfluous." Ibid., 56.

44. As I argue below, this partiality was in a sense both intentional and unwitting. The Rebel was to be followed by a third essay, The Myth of Nemesis, which would have completed the historical analysis Camus had begun with The Myth of Sisyphus. Because they were parts of a greater structure and a larger project, Camus set very clear limits to the scope of each of his philosophical essays. However, he sometimes fails to achieve his goals even within the terms set by those limitations.

45. Frantz Favre's recent book explores the manner in which Nietzsche helped Camus to overcome the pressures of modernity. He claims that what Camus takes from Nietzsche is less his immoralism than his tragic sensibility and his "besoin de noblesse, le courage et la lucidité." Frantz Favre, Montherlant et Camus: une lignée nietzschéene (Paris: Lettres modernes minard, 2000), 20.

46. Albert Camus, "Prometheus in the Underworld" in Lyrical and Critical Essays, 139.

47. Albert Camus, The Rebel, 190.

48. Here the term cyclical refers to those books that belong thematically to one or the other cycle of Camus' works. I explain the significance of these books and their role in Camus work as a whole below.

49. Albert Camus, The Rebel, 190.

50. "In contrast to the ancient world, the unity of Christian and Marxist world is astonishing." Ibid., 189.

51. Albert Camus, The Myth of Sisyphus, 33-34. 
Ph.D. Thesis - R. Srigley McMaster - Religious Studies

52. Ibid, 54.

53. Ibid., 110.

54. "If there is no human nature, then the malleability of man is, in fact, infinite... Guided by a determinist hypothesis that calculate the weak points and the degree of elasticity of the soul, these new techniques have once again thrust aside one of man's limits and have attempted to demonstrate that no individual psychology ir original and that the common measure of all human character is matter." Albert Camus, The Rebel, 237-239.

55. Albert Camus, "Helen's Exile" in Lyrical and Critical Essays, 149.

56. Albert Camus, The Rebel, 238.

57. Ibid., 27.

58. As Jean Baudrillard says, "No event is 'real' any longer. Terror attacks, trials, wars, corruption, opinion polls - there's nothing now that isn't rigged or undecidable." Jean Baudrillard, The Spirit of Terrorism, trans. Chris Turner (London: Verso, 2003), 80.

59. Albert Camus, The Rebel, 236. Camus gives the example of Pravda, but he also cites the Spiritual Exercises of Saint Ignatius: "We should always be prepared, so as never to err, to believe that what I see as white is black, if the hierarchic Church defines it thus'." Ibid., 242.

60. "The whole world absentmindedly turns its back on these crimes; the victims have reached the extremity of their disgrace: they are a bore. In ancient times the blood of murder at least produced a religious horror and in this sanctified the value of life. The real condemnation of the period we live in is, on the contrary, that it leads us to think that it is not bloodthirsty enough." Ibid., 279-280.

61. Jeffrey Isaac explores some of the similarities and dissimilarities between Camus and postmodern thought. Jeffrey Isaac, Arendt, Camus, and Modern Rebellion, 227-235. Isaac argues that Camus' critical appropriation of the modern project might have made him a better postmodern than the postmoderns. Though there are, as I have said, such impulses in Camus' books, they are excesses and not the main thrust of the analysis. In order to create the impression that they are, Isaac, like Sprintzen, dismisses Camus' Hellenism and his concern with nature, human and otherwise, as an "unreflective" aspect of his writing. That strategy simultaneously distorts Camus' achievement and takes the Greeks off the table in order to confine the debate to an essentially in-house quarrel between moderns 
$\mathrm{Ph} . \mathrm{D}$. Thesis - R. Srigley McMaster - Religious Studies

and postmoderns that neither party can ultimately lose.

62. Albert Camus, The Myth of Sisyphus, 54.

63. Ibid., 53.

64. Jean Baudrillard is one of the best observers of these contemporary manifestations of the modern project. Cf. Jean Baudrillard, The Transparency of Evil: Essays on Extreme Phenomena, trans. James Benedict (London: Verso, 1993) and The Perfect Crime, trans. Chris Turner, (London: Verso, 1996).

65. "It would be possible to demonstrate in this manner that only two possible worlds can exist for the human mind: the sacred (or, to speak in Christian terms, the world of grace) and the world of rebellion. The disappearance of one is equivalent to the appearance of the other, despite the fact that this appearance can take place in disconcerting forms." Albert Camus, The Rebel, 21.

66. "That God should, in fact, be exiled from this historical universe and German ideology be born where action is no longer a process of perfection but of pure conquest, is an expression of tyranny." Ibid., 299-300.

67. "There is, in fact, no conciliation possible between a god who is totally separated from history and a history purged of all transcendence. There representatives on earth are, indeed, the yogi and the commissar." Ibid., 288. For an account of the terms "yogi and commissar" in their original context and Camus' source, see Arthur Koestler, The Yogi and the Commissar and Other Essays (New York: The MacMillan Company, 1967).

68. "If, in fact, the solitary mind must be explained by something outside man, then man is on the road to some type of transcendence. On the other hand, society has only man as its source of origin; if, in addition, it can be affirmed that society is the creator of man, it would seem as though one had achieved a total explanation that would allow the final banishment of transcendence." Albert Camus, The Rebel, 200.

69. Albert Camus, Notebooks 1942-1951, trans. Justin O'Brien (New York: Paragon House, 1991), 145-146.

70. Ibid., 158.

71. Albert Camus, Carnets III: Mars 1951-Décembre 1959, 187.

72. Albert Camus, Notebooks 1942-1951, 257. 
Ph.D. Thesis - R. Srigley McMaster - Religious Studies

73. Albert Camus, Carnets III, 187. The theme of these works is "heros of our time," the title of Lermontov's novel and part of the epigraph for The Fall.

74. Ibid. The proposed books of the third cycle were "le Premier Homme, Don Faust. Le Myth of Némésis." Le premier homme was a third finished in manuscript form at the time of Camus' death; the latter two works were being actively sketched out in the notebooks. For "Nemesis," see Carnets III, 44, 78, 81, 187, 190, 207, 274. For "Don Faust," see Carnets III, 20, 21, 87, 110, 130, 186, 198.

75. Serge Doubrovsky's essay "The Ethics of Albert Camus" is an excellent discussion of the allusive character of this and other of Camus' basic principles. In Germaine Brée, Camus: A Collection of Critical Essays, ed. Germaine Brée (Englewood Cliffs N.J.: Prentice Hall, 1962), 71-84.

76. The evidence in support of this claim is too extensive to list here. I note only that both The Myth of Sisyphus and The Rebel conclude with a call to return to Greeks, and that this same aspiration is apparent in all of Camus's important shorter essays: "The Enigma," "Helen's Exile," "Return to Tipasa," "Prometheus in the Underworld," and "The New Mediterranean Culture." The shorter essays are all found in Albert Camus, Lyrical and Critical Essays.

77. This is a refrain that begins to appear in the notebooks in the late '40s. I discuss it in some detail below.

78. The first tendency is apparent in Thomas Merton and to a lesser degree in Eric Voegelin. Both recognize that Camus was a critic of modernity, but their own assessments of the Greeks as limited in comparison to Christianity or some other, more differentiated account effectively marginalize his insights. Paul Archambault's book is a good example of the latter tendency, although it contains elements of the first also. I examine Archambault's argument and explain its limitations in my Introduction to Albert Camus, Christian Metaphysics and Neoplatonism, trans. Ron Srigley (Columbia: University of Missouri Press, 2007). Thomas Merton, "Camus: Journals of the Plague Years," The Sewanee Review, Autumn, 1967. Eric Voegelin, Anamnesis, 170-172, 188190. Paul Archambault, Camus' Hellenic Sources (Chapel Hill: The University of North Carolina Press, 1972).

79. R. W. B. Lewis, The Picaresque Saint (London: Gollancz Ltd., 1960), 61-2. See also Voegelin, Anamnesis, 190. 
Ph.D. Thesis - R. Srigley McMaster - Religious Studies

80. The following description of the chronological interpretation is based principally on two sources: Jeffery Isaac, Arendt, Camus, and Modern Rebellion and David Sprintzen, Camus: A Critical Examination. Many other sources could have been used: John Cruickshank, Albert Camus and the Literature of Revolt, Jean Onimus, Albert Camus and Christianity, André-A. Devaux, "Albert Camus: Le christianisme et l'hellenisme," Nouvelle Revue Luxembourgeoise, janvier-avril 1970, 11-30, Joseph C. McLelland, Prometheus Rebound: The Irony of Atheism, to name only a few. I choose Isaac and Sprintzen because they articulate coherently and comprehensively much of what is only partially developed in these other works and because their own researches make it clear that there has been no significant change in Camus scholarship during the intervening thirty years or so.

81. After citing a lengthy passage from Nuptials, Sprintzen writes: "Here is the human animal practically at one with nature." Sprintzen, Camus: A Critical Examination, 10.

82. Isaac, Arendt, Camus, and Modern Rebellion, 232. Sprintzen, Camus: A Critical Examination, 275.

83. Isaac, 231-242. Sprintzen, 133, 273-ff.

84. David Sprintzen, Camus: A Critical Examination, 277: "No wonder when Camus came to write about Marx, while appreciating the incisiveness of the Marxisn critical analysis as well as th dangers inherent in the Marxian prophetic tradition, he totally misses (as Sartre suggested) the center of Marx's vision: humanity's collective selfcreation through time - in short, Marx's philosophical anthropology." An almost identical criticism can be found in Isaac, Arendt, Camus, and Modern Rebellion, 240: "Arendt and Camus may have acutely perceived its weaknesses, but they failed to recognize the richness of Marxism as a political tradition. Both ignore the efforts of twentieth-century Marxists - and here Rosa Luxemburg was less unusual than Arendt allows - to rethink historical materialism and reconsider the kinds of pedagogical and coalitional politics required by a vital social movement."

85. Consider the following from Nuptials and The Rebel on the question of death. First Nuptials: "The most loathsome materialism is not the kind people usually think of, but the sort that attempts to let dead ideas pass for living realities, diverting into sterile myths the stubborn and lucid attention we give to what we have within us that must forever die." Albert Camus, "The Desert" in Lyrical and Critical Essays, 98. Now The Rebel: "Men are never really willing to die except for the sake of freedom: therefore they do not believe in dying completely." Albert Camus, The Rebel, 291. 
Ph.D. Thesis - R. Srigley McMaster - Religious Studies

86. The following passage is typical in this regard: "Few people realize that there is a refusal that has nothing to do with renunciation. What meaning do words like future, improvement, good job have here? What is meant by the heart's progress? If I obstinately refuse all the 'later ons' of this world, it is because I have no desire to give up my present wealth. I do not want to believe that death is a gateway to another life. For me, it is a closed door. I do not say it is a step we must all take, but that it is a horrible and dirty adventure. Everything I am offered seeks to deliever man from the weight of his own life. But as I watch the great bird flying heavily through the sky at Djemila, it is precisely a certain weight of life I ask for and obtain." Albert Camus, "The Wind at Djemila" in Lyrical and Critical Essays, 76.

87. Albert Camus, Lyrical and Critical Essays, 73-79, 80-92, 93-105. In The Rebel Camus writes: "The first and only evidence that is supplied me, within the terms of the absurdist experience, is rebellion. Deprived of all knowledge, incited to murder or to consent to murder, all I have at my disposal is this single piece of evidence, which is only reaffirmed by the anguish I suffer." Albert Camus, The Rebel, 10.

88. This notion is reflected in the title of The Wrong Side and the Right Side and is one of its main themes.

89. Albert Camus, The Rebel, 4.

90. Albert Camus, The Myth of Sisyphus, 10.

91. Ibid., 159.

92.Albert Camus, The Fall, trans. Justin O'Brien (New York: Vintage International, 1991).

93. Here is an example from The Rebel of this type of reasoning, in which Camus occasionally and lamentably indulged: "Why wish for immortality if the aspect of life is so hideous? There is no method of thought that is absolutely nihilist except, perhaps, the method that leads to suicide, any more than there is absolute materialism. The destruction of man once again affirms man. Terror and concentration camps are the drastic means used by man to escape solitude. The thirst for unity must be assuaged, even in the common grave. If men kill one another, it is because they reject mortality and desire immortality for all men." Albert Camus, The Rebel, 247.

94. Ibid., 58, 102. 
Ph.D. Thesis - R. Srigley McMaster - Religious Studies

95. Ibid., 23, 55 .

96. This is an important insight when it comes to the matter of the structure of Camus' corpus as a whole. It would take a good deal of textual interpretation to make my argument convincingly, but a basic summary of the problem the argument seeks to address can be easily stated. Throughout his career Camus wrote shorter lyrical essays that paralleled his cyclical books and that shared (roughly) their themes. But there is something odd about these essays. They do not contain, or do not contain to the same degree, the kinds of modern excesses and confusions apparent in the cyclical books to which they are temporally and thematically companion. The question this raises is the following: Why would Camus write major books that were considerably less insightful and more beset by modern confusions and excesses than what he had managed to achieve and express elsewhere? I explore this question and offer a provisional answer to it in the conclusion of this thesis.

\section{Albert Camus, Christian Metaphysics and Neoplatonism.}

98. Albert Camus, Notebooks 1942-1951, 183.

99. This understanding is evident in dozens of notebook entries and published remarks. The following passages from Notebooks 1942-1951 is only a sample. "It is Christianity that explains bolshevism. Let's keep the balance in order not to become murderers" (184). "For Christians, Revelation stands at the beginning of history. For Marxists, it stands at the end. Two religions" (188). "For the past two thousand years the Greek value has been constantly and persistently slandered. In this regard, Marxism took over from Christianity. And for two thousand years the Greek value has resisted to such a degree that, under its ideologies, the twentieth century is more Greek and pagan than Christian and Russian" (263).

100. In The Rebel, the closer Camus gets to modern revolutionary movements the more the comparisons with Christianity suggest themselves. See the chapter "State Terrorism and Rational Terror" in particular. Albert Camus, The Rebel, 188-245. Yet despite these comparisons Camus still strikes a conciliatory attitude in relation to Christianity. Here is one example: "Christianity, no doubt, was only able to conquer its catholicity by assimilating as much as it could of Greek thought. But when the Church dissipated its Mediterranean heritage, it placed the emphasis on history to the detriment of nature, cause the Gothic to triumph over the romance, and, destroying a limit in itself, has made increasing claims to temporal power and historical dynamism." Ibid., 299. 
Ph.D. Thesis - R. Srigley McMaster - Religious Studies

101. In The Rebel, the closer Camus gets to modern revolutionary movements the more the comparisons with Christianity suggest themselves. See the chapter "State Terrorism and Rational Terror" in particular. Albert Camus, The Rebel, 188-245. Yet despite these comparisons Camus still strikes a conciliatory attitude in relation to Christianity. Here is one example: "Christianity, no doubt, was only able to conquer its catholicity by assimilating as much as it could of Greek thought. But when the Church dissipated its Mediterranean heritage, it placed the emphasis on history to the detriment of nature, cause the Gothic to triumph over the romance, and, destroying a limit in itself, has made increasing claims to temporal power and historical dynamism." Ibid., 299.

102. Albert Camus, Notebooks 1942-1951, 257 and Carnets III, 187. "Nemesis. Profound complicity of Marxism and Christianity (to develop). That is why I am against them both." Albert Camus, Carnets III, 209.

103. See Albert Camus, Christian Metaphysics and Neoplatonism.

104. Albert Camus, Lyrical and Critical Essays, 15, 16.

105. The epigraphs to The Myth of Sisyphus and The Rebel both have Greek or Greek inspired sources and both are directed against aspirations to immortality: " $\mathrm{O}$ my soul, do not aspire to immortal life, but exhaust the limits of the possible' - Pindar, Pythian iii." Albert Camus, The Myth of Sisyphus, epigraph. " And I openly pledge my heart to the grave and suffering land, and often in the consecrated night, I promised to love her faithfully until death, unafraid, with her heavy burden of fatality, and never to despise a single one of her enigmas. Thus did I join myself to her with a mortal cord' - Hölderlin, The Death of Empedocles." Albert Camus, The Rebel, 2.

106. The Rebel appeared in 1951. The Fall did not appear until 1956. Camus was at work on the Le Premier homme in 1960 when he died. It was to be the novel for the third cycle.

107. See Ronald Aronson, Camus and Sartre: The Story of a Friendship and the Quarrel that Ended It, 176-ff.

108. See Ibid. See also Oliver Todd, Albert Camus: A Life, 311-ff.

109. Ibid., 171.

110. Albert Camus, Notebooks 1942-1951, 270

111. Ibid., 255, 210. 
Ph.D. Thesis - R. Srigley McMaster - Religious Studies

112. Ibid., 157.

113. The only text we have that belongs to the third cycle of books is the incomplete and posthumously published Le premier homme. It lives up to its billing. It is a different kind of book from the novels that preceded it and bears an extraordinary resemblance to Camus' first writings. But because the work is both incomplete and unedited any judgement about it will have to be tentative at best.

114. These flaws and confusions are particularly apparent in Camus' histories, but can also be seen in the novels and plays belonging to the cyclical structure.

115. What Camus says about Ivan Karamazov in the closing pages of The Rebel is typical of this practice. After criticizing the excessive or metaphysical nature of Karamazov's rebellion in the chapter devoted to that book, Camus then goes on to offer Karamazov to the reader, and without qualification, as the purest example of rebellion he can find: "The most pure form of the movement of rebellion is thus crowned with the heart-rending cry of Karamazov: if all are not saved, what good is the salvation of one only?" Albert Camus, The Rebel, 304.

116. Georges Bataille and Eric Voegelin offer similar critical assessments of Camus' attempt to derive a moderate form or rebellion from the excesses of metaphysical rebellion, though they both agree with Camus about the need for such moderation. George Bataille, "The Age of Revolt" in The Absence of Myth, trans. Michael Richardson (London: Verso, 1994). 158-176. Eric Voegelin, Anamnesis, 188-190. I discuss both authors' arguments in detail below.

117. As an example of this approach, consider what Camus says about the notion of original sin: "The revolutionary spirit rejects original sin. By so doing, it sink into it. The Greek spirit doesn't think of it. By so doing, it escapes it. Albert Camus, Notebooks 1942$1951,265$.

118. Albert Camus, Carents III, 187. "Avant le troisième étage: nouvelles d' 'un héros de notre temps.' Théme du jugement et de exil."

119. Albert Camus, The Fall, 58.

120. "Her death would, on the one hand, have definitely fixed our relationship and, on the other, removed its compulsion. But one cannot depopulate the planet in order to enjoy a freedom that cannot be imagined otherwise. My sensibility was opposed to this, and my love of mankind." Albert Camus, The Fall, 67. Camus offers a similar insight in one of 
Ph.D. Thesis - R. Srigley McMaster - Religious Studies

the clearer passages from the Introduction to The Rebel: "Absolute negation is therefore not consummated by suicide. It can only be consummated by absolute destruction, of oneself and of others." Albert Camus, The Rebel, 7.

121. Albert Camus, The Fall, 144-147.

122. Ibid., epigraph.

123. I am indebted to Serge Doubrovsky's essay "The Ethics of Albert Camus" for the first suggestion of such a movement. Serge Doubrovsky, "The Ethics of Albert Camus" in Camus: A Collection of Critical Essays, 72-84.

124. Camus had a good relationship with Martin Buber and was well-disposed to his I/Thou philosophy. Buber, for his part, considered The Rebel a book of great "importance for human life at this hour" and ensured its publication in Hebrew. Martin Buber, The Letters of Martin Buber: A Life of Dialogue, eds. Nahum N. Glatzer and Paul MendesFlohr, trans. Richard and Clara Winston and Hary Zohn (New York: Schocken Books, 1991), 568-569. 
Ph.D. Thesis - R. Srigley McMaster - Religious Studies

\section{PART ONE: THE HISTORICAL ESSAYS}

Introduction

The historical character of Camus' essays The Myth of Sisyphus and The Rebel is often overlooked by commentators; and so too is their odd nature. Both books begin with modern problems or sentiments in existence. But in their respective attempts to discover the origins of those sentiments each subsequent work pushes back further historically than the one that precedes it. In its search for the origin of the absurd The Myth of Sisyphus extends back as far as the middle nineteenth century. The Rebel begins with the revolutionary movements of the twentieth century and then tracks their developments back to the middle of the eighteenth century. But The Rebel's analysis too did not quite manage to discover the origins of modernity. Its history also proved to be too limited in scope to yield the kinds of answers that Camus was looking for. Thus his proposed third essay, "The Myth of Nemesis." This work also was to begin with the question concerning the nature of modernity. But it was to reach back past the modern era entirely all the way to Greek antiquity and Christianity in order to explain the source and nature of the contemporary world. ${ }^{2}$ In this part of the thesis I will explore The Myth of Sisyphus and The Rebel with an eye to their historical character and in hopes of learning something about Camus' critique of modernity and his account of its relationship to Christianity.

The other aspect of these essays that is frequently overlooked is their place in the overall cyclical structure of Camus' oeuvre. Commentators often acknowledge that such a 
Ph.D. Thesis - R. Srigley McMaster - Religious Studies structure exists in Camus' books but they rarely comment on it further than to say that it denotes a straightforward movement of development from the earliest books to the latest. The nature of this structure is something I will explore in greater detail in the conclusion to this work. For now two observations are in order. However one interprets the cyclical structure of the books it is clear that the findings of both The Myth of Sisyphus and The Rebel are somehow provisional in nature. Their provisional character is partly intentional, partly unintentional. From about the middle forties Camus had planned to carry out his analysis of modernity in at least three different stages or cycles of books organized according to the themes of the absurd, rebellion, and love. ${ }^{3}$ Since The Myth of Sisyphus and The Rebel belong to the first two cycles respectively we know that they do not contain Camus' best or most complete critical analysis. But we also know this from the content of their analyses. The Myth of Sisyphus suggests the possibility of a movement beyond the experience of the absurd through its account of the experience itself and through its emphasis on the notion of rebellion. ${ }^{4}$ In The Rebel Camus is even more explicit and perhaps more circumspect about the provisional nature of the analysis. ${ }^{5} \mathrm{He}$ warns the reader about it in the opening pages of the book; ${ }^{6}$ and he reasserts it and gives the direction to which it points a content in the conclusion when he discusses the notion of love. $^{7}$

The unintentionally provisional character of these analyses is less obvious than the intentional one. It requires some explanation. Camus sets out in these books to explore 
Ph.D. Thesis - R. Srigley McMaster - Religious Studies and assess critically the modern project. But he chooses an odd method to do so. He begins each analysis by selecting a dominate modern idea or sentiment that he claims to have found in "the streets of [his] time." ${ }^{\prime 8} \mathrm{He}$ then asserts that that idea or sentiment is all he has to go on in his attempt to understand the modern phenomenon with which he is confronted. ${ }^{9}$ This unusual procedure involves Camus in a number of confusions, the most significant of which is that it renders his analyses, despite their many insights and successes, somehow divided against themselves. His acceptance of modern accounts of the absurd and rebellion occasionally leads him to argue, against his better judgement, in favour of the very modern excesses he originally sets out to criticize. It is my argument that this methodology finally broke down after the publication of The Rebel, though evidence of its inadequacies is also apparent in The Myth of Sisyphus. ${ }^{10}$ Modern interpretations of contemporary experiences do not lead to non-modern accounts of them unless a good deal more is added to the analysis than what is permitted by the original interpretation. Moreover this methodological confusion at times also belies a substantial one. The problem is not merely that Camus is limited by an interpretation that is unnecessarily restricting but that he is also somehow seduced or compelled by the content of that interpretation. His analysis of apocalyptic aspirations in The Rebel is a case in point. It is hampered not only by his method but by the fact that he too shares these aspirations, at least in some measure.

I have chosen The Myth of Sisyphus and The Rebel in order to explore both the 
Ph.D. Thesis - R. Srigley McMaster - Religious Studies positive accomplishments of Camus' cyclical works and to illuminate their substantial and methodological difficulties. This could also have been done through an analysis of Camus' fiction, say The Stranger and The Plague or even Caligula. These texts offer good and sometimes even better versions of the affirmative and critical aspects of Camus' account, but they are usually less illuminating when it comes to the substantial and methodological problems that I have mentioned. For some reason these problems are less acute in Camus' fiction than they are in his essays. Why this is so is difficult to say. My guess is that good fiction by its very nature demands a larger share of reality in order to be compelling than does a philosophical prose essay. Whatever the case may be, I will examine only Camus' histories in this part of the dissertation. Because of the provisional character of these essays my analyses of them will also be provisional in nature. I want to clear away certain interpretive misconceptions about these books that have diminished or obscured the full extent of what Camus accomplished in them. But I also want to bring out their often contradictory character without trying too hard to make them appear consistent. That seems to me the best way to illuminate the nature of Camus' cyclical works in particular and to explore the scope and depth of his philosophical achievement more generally. 
Ph.D. Thesis - R. Srigley McMaster - Religious Studies

Notes

1.Albert Camus, Carnets III: Mars 1951-Décembre 1959, 187.

2. Albert Camus, Notebooks 1942-1951, 267.

3. Ibid., 158, 257. In the first formulation there are five stages. In the next and in all subsequent accounts the third and fifth stages - "judgement" and "creation corrected" are absent, apparently with good reason. The theme of judgement is explored in The Fall as a subsidiary theme; and creation correction is dropped entirely.

4. "One of the only coherent philosophical positions is thus revolt." Albert Camus, The Myth of Sisyphus, 53.

5. Despite how much more circumspect Camus is than Sartre in explaining the sentiment of the absurd, he still occasionally slips into certain excesses and some braggadocio in The Myth of Sisyphus. This is particularly true when he is speaking about morality.

6. Albert Camus, The Rebel, 4.

7. Ibid., 304.

8. Albert Camus, "The Enigma" in Lyrical and Critical Essays, 159.

9. For instance, "The first and only evidence that is supplied me, within the terms of the absurdist experience, is rebellion." Albert Camus, The Rebel, 10.

10. These occur principally in relation to Camus' apparent lack of concern about questions or morals or virtue in The Myth of Sisyphus, which in his later works are central. Here is an example of that apparent lack of concern: "Once and for all, value judgements are discarded here in favour of factual judgements." Albert Camus, The Myth of Sisyphus, 59. 
Ph.D. Thesis - R. Srigley McMaster - Religious Studies

Chapter One: The Absurd Man

[In existentialism] contempt for the ordinary human condition, together with a conviction of personal salvation, saves the writer from real pessimism. His gloom is superficial and conceals elation.

Iris Murdoch, The Sovereignty of the Good

The common, orthodox interpretation of The Myth of Sisyphus is that it endorses a type of existentialism similar to that developed by Jean-Paul Sartre in early works like Nausea, Being and Nothingness, and Existentialism and Humanism. Though most commentators agree that in later works like The Plague and The Rebel Camus attempted in different ways and with varying degrees of success both to qualify and to distance himself from his early existentialism, they argue that the existentialism of The Myth of Sisyphus itself is beyond question.

The two main pieces of evidence most often cited in support of this reading are Camus' apparent negation of any transcendent good, evident in his rejection of what he variously refers to as the "other world" (autre monde), the "eternal" (éternel) or "meaning" (sens), simply, and his corresponding claim that "this world" is meaningless or absurd, that is to say, lacking any natural order of meaning and goodness. According to the existentialist reading, it is these two notions that most clearly reveal Camus's agreement with Sartre concerning the nature of the absurd.

Consider, for example, David Sprintzen's interpretation of the absurd in his book, Camus: A Critical Examination. Sprintzen says that despite their apparent differences, 
Ph.D. Thesis - R. Srigley McMaster - Religious Studies "the tendency to lump Camus and Sartre together under the aegis of existentialism is not completely inappropriate." He claims that the appropriateness of this tendency stems from the fact that Camus and Sartre "share basic concerns nurtured by a common historical situation." According to Sprintzen, the most important of these concerns and hence the real source of their commonality lies "in their effort to help us face a world in which transcendent absolutes can no longer be appealed to or relied upon." This effort is the central task of The Myth of Sisyphus. As Sprintzen writes, apart from Camus' occasional confusions, the absurd for him "is primarily concerned with the loss of belief in any extrinsic or transcendent meaning to existence."3

Sprintzen's use of the language of "concerns," "beliefs," and "appeals" to describe Camus's understanding of transcendence and its bearing on the problem of the absurd tends to leave his discussion ambiguous. Fortunately, elsewhere in his analysis Sprintzen explains the meaning of Camus's concern with such things more simply and straightforwardly: he says that for Camus the "death of God" and the "perception of life's ultimate absurdity" are fundamental givens. ${ }^{4}$ Even more simply, we might say that for Sprintzen the absurd is merely this world without God.

Bruce Ward would disagree with Sprintzen's claim that Camus was something of an existentialist. He argues that Camus considered modern existentialism to be a form of nihilism, and that the aim of The Myth of Sisyphus was only to diagnose that nihilism, "not to glory in it." Ward argues instead that the development of Camus's thought, 
Ph.D. Thesis - R. Srigley McMaster - Religious Studies beginning with The Myth of Sisyphus, is best understood as a movement away from such modern accounts toward a Hellenic or Greek understanding of nature. Indeed, he claims that in contrast to Sartre's existentialist account of nature, what Camus "found most compelling in 'Hellenism' was the sense of nature as a sacred order or kosmos, an object of 'contemplation' rather than 'transformation'."'

Though Ward considers Camus's effort "to overcome the modern eclipse of nature" to be sound in principle, he also claims that it may have been severely limited by Camus's rejection of certain Christian teachings, particularly as they are expressed in the works of Dostoevsky. ${ }^{7}$ The most important of these teachings is the Christian notion of the "transcendent good." For instance, Ward argues that in opposition to Dostoevsky's Christian understanding of nature, in which "this world" (nature) and the "other world" (transcendent good) are bound together in an order of love, "the 'nature' to which Camus appeals...is adamantly, and indeed exclusively, this-worldly." Despite his avowed Hellenism, Ward claims that in this regard Camus' nature or "kosmos" seems to be neither Christian nor Greek but thoroughly modern: "Though he...invokes the ancient Greeks, the insistence that loyalty to the earth entails the renunciation of the idea of immortality seems much more evidently in accord with the modern atheism of Nietzsche." Ward argues that in this very important respect Camus's humanism is "subject to the full weight of that question so insistently posed by Dostoevsky's art: can human beings live on an earth which has been divorced from any transcendent good, from 
Ph.D. Thesis - R. Srigley McMaster - Religious Studies what Zossima [in The Brothers Karamazov] calls the 'higher, heavenly world'?"'

Ward finds Camus's omission of any detailed analysis and assessment of the challenge to his understanding of nature posed by Zossima's question strange. He suggests that the strangeness of this omission is most evident in light of Camus's insightful and sustained encounter with another of Dostoevsky's characters - Stavrogin in Devils - who so clearly illustrates the consequence for life of rejecting Zossima's teaching. Ward asks: "what is Stavrogin's gradual descent into self-destruction if not a compelling illustration of the monk's teaching that an exclusive loyalty to this world will finally result in indifference to, and even hatred of, life." In terms of the problem of the absurd, we might reformulate Ward's question in this way: how can Camus avoid something very much like the "absurdity of existence" argued for by Sartre and depicted by Dostoevsky in the character of Stavrogin given his denial of any transcendent good and his "adamantly this-worldly" account of nature?

Despite some of the differences between their respective interpretations of the absurd, Ward and Sprintzen agree about its fundamental character: the absurd is the experience of nature or this world without God or the transcendent good. Moreover, they both agree that in all of his subsequent attempts to overcome the apparent nihilism of the absurd evident in The Myth of Sisyphus, Camus remained adamant in his refusal of any appeal to such a transcendent good. More notable still is the fact that in their critical assessments of these subsequent attempts, Ward and Sprintzen agree that the real problem 
Ph.D. Thesis - R. Srigley McMaster - Religious Studies with Camus's account lies in his Greek conception of nature, though the reasons for their criticisms differ in important ways.

Consider once again Sprintzen's interpretation. Sprintzen argues that Camus's works evince a gradual movement toward a purely historical account of meaning similar to that offered by Marx and Hegel. The Myth of Sisyphus is the "point of departure" for this development, insofar as it affirms the world's lack of any divine or natural order. Camus's search for a historical account of meaning is therefore not idiosyncratic. However, despite this important insight, Camus continued to endorse, albeit inconsistently and perhaps even "prereflectively," an "ill-defined and sometimes substantialized conception of human nature." ${ }^{10}$ Camus's nostalgia for such a substantial natural order, inherited from the traditions of the classical West, somehow prevented him from understanding the full meaning and import of Marx's (and indeed his own) "historicization of nature." Sprintzen writes: though Camus appreciated "the incisiveness of the Marxian critical analysis as well as the dangers inherent in the Marxian prophetic tradition, he totally misses (as Sartre suggested) the center of Marx's vision: humanity's collective self-creation through time-in short, Marx's philosophical anthropology."12 In slightly different words, for Sprintzen Camus's Greek or "Western" understanding of nature ultimately failed for the simple reason that the world has no such nature. Nature is history.

Unlike Sprintzen, Ward does not object to Camus's effort to find meaning in 
Ph.D. Thesis - R. Srigley McMaster - Religious Studies nature. With Dostoevsky, he argues that a natural order does exist, and that Camus's various attempts to explore it and understand it are, as I said, sound in principle. Indeed, Ward claims that such efforts are important precisely because they provide a necessary "counter-weight to the modern historical sense" of writers like Marx and Hegel that in our time threatens to obscure the natural order entirely. ${ }^{13}$ The criticism of Camus implied by Ward's analysis has a different source than that of Sprintzen.

The evident meaning of his comparative study of Camus's Hellenic understanding of nature and Dostoevsky's Christian understanding is that Camus did not and could not experience "this-world" or nature as "the embodiment of the divine" because he did not accept the Christian teachings of the incarnation and the immortality of the soul. ${ }^{14}$ As Ward rightly argues, Zossima's "nature-mysticism" is not "Romantic." Nor are his "other mysterious worlds." To the contrary, Zossima's teaching is "tied explicitly" to the Christian doctrine of the Word made flesh: "'the Word is for all; all creation, all creatures, every leaf are striving toward the Lord, glorify the Lord, weep to Christ'..."15 The meaning of this teaching for Ward's assessment of Camus's understanding of nature is clear: because Camus did not accept the Christian revelation of Jesus as God and the teaching of the resurrection, both of which are known only through faith or the "heart," he was left with a world entirely "divorced from any transcendent good," and indeed, from any moral order or good of any kind. ${ }^{16}$

Ward suggests an explanation for this unhappy outcome in his discussion of 
Ph.D. Thesis - R. Srigley McMaster - Religious Studies Dostoevsky's Christian understanding of reason. He says that for Dostoevsky, "reason, itself essentially a 'material capacity,' cannot be the means of transcending the realm of material necessity; nature, seen through the reason alone, is inevitably seen as chance and necessity, and nothing but chance and necessity. The mode of knowing must be adequate to what is to be known, and therefore, if what Zossima calls the higher 'spiritual world' is to be experienced, it must be experienced with the 'higher half' of our being-the spiritual faculty of the 'heart'."17 This is a familiar account of natural reason with a long pedigree in the Christian tradition. Again its meaning for Ward's analysis of Camus is clear: given Camus's evident rejection of the truths of the heart as they are understood by Christians like Dostoevsky, and given his insistence that the experience of the absurd stems in large part from the corruption of the human capacity for "intelligence" or "reason," even if that corruption were to be overcome he would at best be left with a world of mere "chance and necessity," that is to say, a world devoid of spiritual substance or meaning.

Readings of The Myth of Sisyphus like those I have outlined above tend to interpret the absurd in light of other doctrines or teachings, whether modern existentialism and historicism or Christianity. Such comparative analyses are both legitimate and necessary in the context of a critical discussion. They are, however, illegitimate and highly misleading when used for the purpose of interpretation. To say that Camus's understanding of nature is deficient when compared to some other account 
Ph.D. Thesis - R. Srigley McMaster - Religious Studies

of nature is one thing; it is quite another to explain what that understanding is on its own terms, with all its strengths and weaknesses. The tendency to interpret Camus in this way is particularly problematic in the case of The Myth of Sisyphus.

Certainly Camus shared with both existentialists and Christians a common concern about the pervasive sense of meaninglessness or absurdity evident in modernity. But no more than that. The expressed aim of The Myth of Sisyphus is to describe the experience of the absurd in what Camus calls its "pure state" (état pur), that is to say, differently than it is described by Christians and existentialists. ${ }^{18}$

Consider again the fundamental feature of what I have called the orthodox, existentialist interpretation of The Myth of Sisyphus. Both Ward and Sprintzen agree that the absurd is best understood as the experience of this world without God or the transcendent good. Broadly speaking, the debate between Christians and existentialists turns on this basic question. Either God exists and the world has a meaning, or he does not and the world is meaningless or absurd. The same holds true with regard to questions of goodness. Either God exists and there is a measure for human action, or he does not and human will and action are without measure. According to the existentialist reading of The Myth of Sisyphus, Camus' rejection of the "other world" or transcendent good is the best evidence that he accepted the terms of this debate, and that he willingly assumed his place in it - on the side of the existentialists.

Now at the conclusion of his analysis Camus does say that "there is only one 
Ph.D. Thesis - R. Srigley McMaster - Religious Studies world" (il n'y a qu'un monde), which would seem to support the existentialist reading. ${ }^{19}$ However, given certain other features of Camus's analysis, we might well wonder what this means. For example, what does Camus mean when he says that "there is only one world"? How does he describe this world? What does it include and what does it exclude? Does it exclude God or the gods? What is the "other world" (autre monde) that Camus rejects as an "illusion"?

A good deal of textual exegesis is necessary to answer these questions adequately. Nonetheless, a few preliminary remarks in response to them are possible. I would suggest that a close reading of The Myth of Sisyphus reveals that Camus' "one world" differs in important ways from the common existentialist interpretation of it. More specifically, I would argue that it includes a great many things - among them meaning, goodness, and transcendence - that, according to the existentialist reading, it does not and cannot include. Consider only the following features of Camus's analysis.

First, Camus says that the absurd man desires to know what is "true"and to avoid "falsehood. ${ }^{.20} \mathrm{He}$ wants to approach his "naked reality" (réalité nue) and to escape the various "phantoms" (fantômes) and "illusions" (illusions) that obscure his understanding of that reality. ${ }^{21}$ This language is traditional, and Camus uses it in traditional ways. Among other things, it implies that there is in The Myth of Sisyphus a principled distinction between appearance and reality, that is to say, between phenomena and their meaning or substance. This distinction alone suggests that whatever the experience of the 
Ph.D. Thesis - R. Srigley McMaster - Religious Studies absurd may be, it does not involve the denial of a natural order of meaning and truth. To the contrary, the desire to apprehend the nature of that order is precisely what motivates Camus's inquiry.

Second, despite Camus's claim that the absurd involves a rejection of all "judgements of value" (jugements de valeur), and that all forms of life are thus "equivalent," he also argues explicitly and without irony that the absurd man wants to achieve a "moral rule" (règle d'une morale), albeit not a "formal" (formelle) one. ${ }^{22}$ As with his account of truth, here also Camus describes his "moral rule" in traditional ways. For instance, he says that the life the absurd man seeks to live is characterized by "nobility" (grandeur), "chaste friendship" (amitié si pudique), "fidelity" (fidélité), "obligations" (servitudes), "self-mastery" (maîtrise de soi), and "measure" (mesure), all of which imply the existence of a moral order of some kind..$^{23}$ Moreover, he suggests that the achievement of this type of life is somehow related to the cultivation of the virtues. Though The Myth of Sisyphus does not include a detailed analysis of these virtues, Camus nonetheless mentions them all in relation to the life to which the absurd man aspires. As he describes it, that life is one characterized by "justice," "courage," a "difficult wisdom," and moderation or "measure." 24

Finally, the absurd man does not deny or negate transcendent reality, as Ward and Sprintzen argue. Camus's claim that there is only one world is obviously opposed to the notion that there are two worlds. However, the interesting thing about his account is that 
Ph.D. Thesis - R. Srigley McMaster - Religious Studies he does not equate the "other world" with transcendence or God per se. For example, Camus argues repeatedly that the absurd man is precisely one who is "at grips with a reality that transcends him" (aux prises avec une réalité qui le dépasse) in various ways. ${ }^{25}$ This statement alone indicates that Camus is little inclined to deny realities simply because they are greater than or exceed him. More importantly, this unwillingness is also evident in his assessment of experiences of transcendence in the eminent sense as God. Indeed, when Camus discusses Christian writers like Dostoevsky and Kierkegaard, the one aspect of their teachings that he consistently excludes from his criticism is precisely their affirmation of God.

Consider only two examples. At the conclusion of his analysis of The Brothers Karamazov, Camus argues that "what contradicts the absurd in that work is not its Christian character but rather its announcing of a future life [vie future]. It is possible to be Christian and absurd. There are examples of Christians who do not believe in a future life. ${ }^{.26}$ Here Camus's criticism of Christianity does not concern the experience of God itself, but only the Christian tendency to conflate that experience with the quite different notion of the "resurrection" or "the immortality of the human soul."27 Camus qualifies his criticism of Kierkegaard's Christian existentialism in a similar way. As in his discussion of Dostoevsky, he criticizes Kierkegaard's notion of a future life, the idea that human beings have an "eternal consciousness" (conscience éternelle) ${ }^{28}$ But once again he warns the reader that this criticism in no way involves a denial of transcendence or God per se. 
Ph.D. Thesis - R. Srigley McMaster - Religious Studies Camus writes: "Let me assert again: it is not the affirmation of God that is challenged here, but rather the logic leading to the affirmation."29

I argue that taken together these three aspects of Camus's analysis indicate that whatever the experience of the absurd may be, it does not involve a negation of transcendence and the corresponding claim that the world is by nature without meaning and goodness common to modern existentialists like Sartre. This is not to say that there is no ambiguity in Camus's discussion of transcendence, meaning, and goodness in The Myth of Sisyphus. There is. It is to say, however, that a close textual analysis of Camus's discussion does not permit the resolution of that ambiguity into an unambiguous rejection of all three.

The first question to be asked by any interpreter of The Myth of Sisyphus is this: What kind of a book is it? In one sense it is a conventional philosophical essay, a "book of ideas" as Camus calls it. ${ }^{30}$ It is obviously learned, it makes frequent reference to other works of philosophy and literature, both ancient and modern, and it strives for the analytic clarity proper to a scholarly work. It is not, however, merely a piece of scholarship. The book also has the character of a story or drama. Indeed, on several occasions Camus describes it in just this way. ${ }^{31}$ Briefly, it is the story of a man who one day "awakens" from his habitual life to discover that it makes no sense, that it is absurd or meaningless. The discussion that follows this initial awakening or insight is something like a dramatic 
Ph.D. Thesis - R. Srigley McMaster - Religious Studies monologue, in which the "absurd man" attempts to understand the meaning of this absurdity, what caused it and what he should do about it. To achieve this dramatic tone, Camus writes The Myth of Sisyphus in the first person singular and in the present perfect tense. Among other things, this technique gives the reader the impression that the absurd man's monologue is occurring spontaneously, and that his question concerning suicide is no idle piece of speculation, but a matter he intends to settle once and for all, either for or against, at the conclusion of his investigation.

The first thing to be noted here is that Camus is not and cannot be the absurd man as he describes him. ${ }^{32}$ Nietzsche is right when he says that no writer can be the character he creates, otherwise he could not have created him. ${ }^{33}$ The fact that Camus writes his book in the first person should not be allowed to obscure this truth. The Myth of Sisyphus was not composed spontaneously, as the absurd man's monologue suggests; nor do we have any evidence that Camus wrote it in order to decide whether or not to kill himself. The Myth of Sisyphus is a written text, deliberately and carefully constructed in all of its aspects, both dramatic and philosophical, with a definite aim in view. That aim is to communicate to the reader something about the experience of the absurd as Camus understands it. What is that understanding, and how does The Myth of Sisyphus aim to communicate it?

Camus's best account of the absurd does not come all at once in The Myth of Sisyphus, but unfolds according to what I have called the work's dramatic structure. That 
Ph.D. Thesis - R. Srigley McMaster - Religious Studies structure has three discernable moments or stages. These stages are organized classically. The book begins with an initial experience of disorder that sets the absurd man's inquiry in motion. At first this experience has no particular designation. The absurd man says only that in its "distressing nudity...it is elusive," and that that elusiveness "deserves reflection. ${ }^{.34}$ What follows are a number of different and even conflicting interpretations of the nature of the experience. However, as the analysis continues these interpretive conflicts are resolved. The absurd man then achieves a measure of order in the midst of the initial disorder. This marks the second stage of the analysis. The absurd man now understands more clearly the true nature of the disorder, and thus recognizes the deficiencies of his initial interpretations.

The final stage of the analysis is an assessment of competing accounts of the disorder currently in vogue in the age, namely, Christian and existentialist accounts. In light of his critically clarified understanding of the experience, the absurd man recognizes not only that the various "solutions" to the disorder offered in these accounts are inadequate, but that they are inadequate precisely because they rest on a misunderstanding of the true nature of the experience itself. In simpler words, Camus comes to understand the sentiment of meaninglessness he finds "widespread in the age" differently than do both Christians and existentialists. ${ }^{35}$ To clarify the nature and significance of that difference is perhaps the main task of The Myth of Sisyphus. The book is a historical and existential analysis of the origins of the absurd that is developed in part through a critical 
Ph.D. Thesis - R. Srigley McMaster - Religious Studies engagement with other competing accounts and histories of that experience.

Camus's initial description of the disorder is something like a thumb nail sketch of modernity, the two main features of which are familiar to us all: the sense that reality is utterly empty of meaning and goodness and the corresponding need to fill up or escape the emptiness in some way. The name Camus gives to this sentiment is "the absurd." ${ }^{36}$ In order to describe it, he draws uncritically from the common stock of explanations current in his time, existentialist explanations primarily. For instance, he says that the absurd teaches us that "all true knowledge is impossible",; ${ }^{37}$ he strongly suggests that reality is merely empty "appearances" or "phenomena" without substance or "meaning"; $; 3$ and he seems to conclude that the universe itself and everything in it is therefore absurd, that is to say, that what underlies appearances are not the things that appear but nothingness or the "void." 39

Perhaps the sheer force of the experience of the absurd is enough to lead one to such extreme, nihilistic conclusions about its meaning, at least for a time. Its suddenness, the way it darkens the understanding by divesting the world of "illusions and lights" may compel one to the conclusion that the world itself is nothing. ${ }^{40}$ It may also shed light on the temptation of suicide, the human "aspiration toward nothingness," as Camus calls it. ${ }^{41}$ Yet regardless of how compelling this conclusion may be, the absurd man himself is apparently not satisfied with it. The clearest evidence of his dissatisfaction is this: rather than concluding the analysis at this point and turning immediately to the question of 
Ph.D. Thesis - R. Srigley McMaster - Religious Studies suicide, he instead undertakes what he calls a "reconnaissance in the origins of the absurd." ${ }^{\text {42 }}$ That is to say, he sets aside his bold claim that the world is bereft of all meaning in favour of a further analysis aimed at understanding more clearly the true source and meaning of the experience of the absurd. The need for such an analysis is the best indication we have thus far that the initial, existentialist interpretation of the absurd is inadequate in some way.

As soon as the absurd man begins to explore the origins of the absurd concretely, his description of the experience changes in important ways. The first thing he realizes is that the sense of meaninglessness and disorder provoked by the absurd is not caused by the collapse of the world into nothingness, as it is, for instance, in Sartre's book, Nausea. ${ }^{43}$ What collapses is not the world itself but what the absurd man calls variously the "stage-sets" (décors), "the images and designs" by which he commonly orders his life. ${ }^{44}$ These terms denote a range of phenomena, from the routines or habits that guide his life practically to the meanings or artifices that guide his understanding, we might say his ideas, simply. The absurd man evokes the collapse or loss of these things by saying that he has emerged into a "desert," that is to say, a place where there are few, if any, human artifacts. $^{45}$

The collapse of these ordering ideas provokes a number of questions, the first of which is the question of agency. Simply stated, who or what causes this collapse to occur? The absurd man's explanation is twofold. On the one hand he says that human 
Ph.D. Thesis - R. Srigley McMaster - Religious Studies nature itself is responsible. Though the use of ideas as a means to understand reality is likely both necessary and inevitable for human beings, it also seems true that it is necessary and inevitable that human beings question and challenge them, and that this activity is something they do by nature. The absurd man conveys the natural character of this activity by describing it as a kind of "awakening" that may lead one to wonder about the order of one's life, about the conventional ways in which one lives and thinks. ${ }^{46}$

However, the absurd is not an experience caused solely by the questioning movements of the human heart and mind. It is also an experience that is suffered. The greater reality in which the absurd man lives is not passive-it acts on him. The difficulty he experiences in his effort to understand the experience, evident in his often conflicting statements about its nature, is due precisely to the fact that the experience is not merely the product of his own nature, but also of the elusive and disturbing movements of the greater reality in which he exists. The absurd man does not cause these movements, nor can he control them. They strike, amaze, and alarm him, leaving his "reason" for the moment "impotent" to understand their meaning. ${ }^{47}$

According to the absurd man, among the most unsettling ways in which the world may act on us are those moments when it simply "withdraws at a distance."48 The world then seems "dense," "strange," "inhuman," perhaps even "more remote than a lost paradise [paradis perdu]. ${ }^{, 49}$ But a paradise nonetheless; and though in some sense lost, not entirely forgotten. For as disturbing as such experiences may be, the absurd man again 
Ph.D. Thesis - R. Srigley McMaster - Religious Studies resists the tendency, common among existentialists, to understand them as signifying a final confrontation with nothingness. It is not nothingness that the absurd man encounters through the collapse of his ideas but the world itself. Indeed, he says that "[t]he world escapes us because it becomes itself again." ${ }^{, 50}$ Moreover, despite the fact that the world escapes him in this way, the absurd man nonetheless experiences enough of its true nature to recognize immediately the illusory character of the "images and designs that [he] had attributed to [the world] beforehand," and also to lose "the power to make use of that artifice." 51 The world is no mere appearance, beneath which lies the void. To the contrary, for the absurd man the world is full of meaning, so much so that it can overturn human conventions and ideas through the mere force of its overwhelming and abiding presence.

These basic insights set the stage for everything that follows in The Myth of Sisyphus. The first thing that follows is an explicit retraction of the existentialist interpretation of the absurd with which the absurd man began his analysis. This marks a turning point in the discussion, the beginning of what Camus calls the absurd man's "recovery," which he distinguishes from both suicide and a "thoughtless" return to the chains of a habitual life. 52 The absurd man now says that his initial judgement was "too hasty." In what he calls his "recovered and now studied lucidity" (clairvoyance revenue et maintenant concertée) he retreats explicitly from his bold claim that the world is absurd or meaningless in itself. ${ }^{53}$ The explanation of the experience he now offers is just the opposite: "the absurd is not in a man (if such a metaphor could have a meaning) nor in the 
$\mathrm{Ph} . \mathrm{D}$. Thesis - R. Srigley McMaster - Religious Studies world, but in their presence together." ${ }^{.54}$ It is, as Camus says, a "divorce" between human being and reality. ${ }^{55}$ This is arguably the most important image Camus uses to describe the experience of the absurd in The Myth of Sisyphus. What does it mean?

The metaphor of divorce indicates that the absurd is a misrelation between human being and reality. The absurd man understands the basic character of that reality in a particular way. He says that it is transcendent, or more simply, that it "transcends [him]" (le dépasse) in various way. ${ }^{56}$ This notion is obviously intended as a criticism of those accounts in which the experience of the absurd is said to be caused by an encounter with a world utterly devoid of meaning. That is clear enough. But it might also means something else. It may mean that there is nothing wrong fundamentally with the order of reality as it is given to human beings. The experience of the absurd is a disorder that may occur within reality, certainly. But it is not a disorder or meaninglessness inhering in reality itself, or in any of its dimensions. As Camus says quite plainly in the Preface to The Myth of Sisyphus, the absurd as he understands it is not a "metaphysic," not a "philosophy," not even a "belief." ${ }^{\text {77 }}$ Rather, it is an affection of the "mind" (esprit), a "state of soul" (état d'âme) arising, as I have said, from a misrelation between human being and the greater reality in which it exists. ${ }^{58}$ In slightly different words, Camus refuses to attribute a possible disturbance in the soul to the structure of the world itself; nor is he willing to attribute it to the structure of human life itself. It is a type of disorder possible in human life, possible given the nature of the world and of the place of human beings in it, nothing 
Ph.D. Thesis - R. Srigley McMaster - Religious Studies

more.

Camus emphasizes this very limited scope of the disorder of the absurd in a number of ways. Any criticism of the world as whole will turn on the notion that human beings can have knowledge of a greater or perfect reality beyond the structure of the world as they commonly experience it. The absurd man denies having any such knowledge, and in doing so he pin points two of the most common contents that knowledge is said to have-he says that he has no "memory of a lost homeland [patrie perdue]" and no "hope of a promised land [terre promise]" beyond the structure of the world as he experiences it in the present. ${ }^{59}$ In other words, he knows nothing of a time of perfection either preceding this world or anticipated to follow it by which any absolute judgement about the nature and value of this world might be made. Closely related to the absurd man's ignorance regarding other, perfect worlds is his fundamental ignorance about the nature of death. Contrary to those who claim to know what death is, the absurd man says that strictly speaking "there is no experience of death" because "nothing has been experienced but what has been lived and made conscious." ${ }^{160}$ This fundamental ignorance about the nature of death precludes the possibility of any final judgement of life that one might be tempted to draw from the fact of human mortality. One simply cannot tell which is better and which worse, life or death. The supposed choice between them is therefore not a real one. It must be accounted for in some other way.

Camus's refusal to judge either the world or human life in any absolute sense is 
Ph.D. Thesis - R. Srigley McMaster - Religious Studies evident in still another way. He says repeatedly that neither in his diagnosis of the absurd nor in his attempt to overcome it does he want "to negate" any naturally occurring reality, whether it be the greater reality in which he lives, human being, or any of their respective dimensions or characteristics. ${ }^{61}$ To negate any of these things would be "to escape" (échapper), "to destroy" (détruire), or to "conjure away" (escamote) the divorce, not to solve it. ${ }^{62}$ Far from any desire to negate these things, Camus says he wants to remain "faithful" (fidèle) to or "to obey" (obéir) the reality brought to light through the experience of the absurd. ${ }^{63}$ The experience of that reality is authoritative. That cannot be altered. But the absurd man is nonetheless left with the question of how he will respond to it. The often cited encouragement to "revolt" in The Myth of Sisyphus is no objection here. The revolt Camus recommends is not an effort to overturn or to remake the structure of reality, an effort common to modern historicists particularly, and perhaps to all forms of modern thought generally. That, he argues, is impossible. ${ }^{64}$ Rather, his revolt is nothing but the benign yet potentially fruitful activity of continuing "to question," "to contemplate" (contempler), even to pray to the greater reality in which he exists. ${ }^{65} \mathrm{We}$ might say that for Camus, revolt is merely an attempt to get the best look at reality possible for a human being, and that both the activity and the result of gaining such a look have important consequences for life.

The absurd is a disturbance that may occur within reality, not a problem with reality itself. That much is clear. But what of the disturbance in this limited or measured 
Ph.D. Thesis - R. Srigley McMaster - Religious Studies sense, what of the true nature of the divorce?

The metaphor of the absurd as a divorce indicates that it is a type of misrelation between human being and reality, as I have said. Camus gives us a clue as to the nature of this misrelation by also calling it a "sickness of the mind" (mal de l'esprit). ${ }^{66}$ When something is sick its condition is deficient in some way. Sickness is a corruption of some naturally occurring thing. A mind that is sick is therefore not corrupt by nature. The absurd man never speaks about the mind in this way. The furthest he goes is to say that the mind, even when it is most "lucid" is still somehow limited ${ }^{67}$ And the fact that something is limited need not imply that it is thereby naturally deficient. For the absurd man the corruption of the mind denotes only a diminution of its ability to exercise properly its normal or given capacities. The main capacity of the mind discussed in The Myth of Sisyphus is the capacity for "reason" or "intelligence." How does this capacity become corrupt?

Though it concerns the mind's ability to exercise its capacity for reason properly, the divorce between human being and reality is not for that matter an epistemological problem in the modern sense. The absurd is not caused by the absence of an intermediary that would somehow enable the absurd man to understand reality, whether it be a theory of knowledge or a theory of language. The greater reality from which the absurd man is divorced is there, immediately present, before just as much as after the collapse of his conventional ideas about it. No mediator is required in order to know it. Indeed, there is 
Ph.D. Thesis - R. Srigley McMaster - Religious Studies good reason to think that the proliferation of such mediators in his time may be just what prevents the absurd man from experiencing reality directly.

Another way of saying this is that the absurd is not a problem in speech. Certainly the absurd man has difficulties speaking properly about the reality he experiences. But these difficulties are not due merely to a confusion about words and their meanings. If anything, just the opposite is true. The absurd man's speech is confused because he is confused; and he is confused because he has lost touch with the things about which he speaks. This implies an important distinction: the absurd man knows that words are not equivalent to the things they attempt to express. For instance, he knows that even his best account of the absurd in speech-his "notion" (notion) that it is a divorce between human being and reality —is not simply equivalent to the experience or "sentiment" (sentiment) itself. ${ }^{69} \mathrm{He}$ knows, moreover, that neither can he overcome or rescind the divorce by means of speech or words alone. The chief example he gives of such an effort is writing a book. To those who claim to find "the consolation of a life" in this way, the absurd man replies flatly: "Creating or not creating changes nothing." Writing is merely a type of "savoir-faire." What the absurd man seeks to acquire transcends this skill; it is what he calls "savoir-vivre." ${ }^{\text {"70 }}$ In a slightly different formulation, he says that the divorce between human being and reality cannot be crossed out "with a stroke of the pen." more demanding activity is required for that.

The absurd man is no intellectual, or if he is, he is at worst a convalescing 
Ph.D. Thesis - R. Srigley McMaster - Religious Studies intellectual. He understands that the absurd is neither a metaphysical problem nor an epistemological problem. It is not even that peculiar "metaphysic of many contemporary thinkers [that] consists in having nothing but an epistemology."72 The sickness of the mind as he understands it is a corruption of its ability to come into contact with reality directly through the normal exercise of its given or natural capacities, that is to say, capacities naturally suited to the task. That is its corruption. That is the divorce, and the real source of the meaninglessness the absurd man experiences. Moreover, for him this corruption is best understood as an erotic matter, even in the case of the mind. The greater reality he seeks to understand is not merely matter in motion - mere chance and necessity, as it were. Rather, he likens it to a beloved from whom he is estranged. ${ }^{73}$ The mind's effort to understand this reality by exercising its capacity for reason is therefore not opposed to the "heart's" effort to come into contact with reality by exercising its capacity for love. ${ }^{74}$ Indeed, he says explicitly that "there are no frontiers between the disciplines that man sets himself for understanding [comprendre] and loving [aimer].,75

To be divorced from reality in this way is obviously a bad condition in which to find oneself. What then are we to make of the abiding and forceful approbative sense of the absurd in The Myth of Sisyphus? What of the absurd man's undeniable effort "to win" the absurd, to achieve it as something sought after $?^{76}$ First of all, there is no dialectic here. For the absurd man a bad condition does not become good merely by being recognized as bad. As we will see below, his notion that the absurd is a divorce from reality is intended 
Ph.D. Thesis - R. Srigley McMaster - Religious Studies precisely as a criticism of all such dialectical forms of reasoning. The approbative meaning of the absurd man's insight has a different source. As a result of his inquiry, he now understands that though he has somehow become exiled from the world, he need not be, and that though he may feel in that condition that the world is not his true homeland, it is. ${ }^{77}$ In other words, in light of his now measured understanding of his condition, he knows that the absurd, the sense of meaninglessness from which he suffers, is not absolute. Though he is sick, he knows he can get better. He now gains that steadiness, that sureness of heart and mind that accompanies all real contact with truth, even contact with hard truths.

All this brings us to the heart of The Myth of Sisyphus. As a result of his patient inquiry the absurd man knows both that his life is deficient and how it is deficient. But this insight carries with it another - he also knows that it is not the only life possible for a human being. A better life may be possible. However - and this is the crucial point - the absurd man never equates this better life with "another life" (autre vie) ${ }^{78}$ it is not, for example, a "future life" (vie future) in the Christian sense. ${ }^{79} \mathrm{~A}$ better life as he understands it is simply a happy life; and this happy life is one that is attainable now, in the present, or in "this world," as the saying goes. Not completely, of course, and not easily. As the absurd man writes, "Happiness and the absurd are two sons of the same earth." ${ }^{, 80}$ The darkening of the understanding brought on by the absurd is a permanent possibility in human life, even "in the best ordered of lives." 
Ph.D. Thesis - R. Srigley McMaster - Religious Studies from reality is then perhaps inevitable for human beings. Yet if one so chooses, it need not exceed that measure.

Not two worlds, then, but "one world," within the abiding or unchanging order of which there are different lives possible for human beings. ${ }^{82}$ Moreover-and this is also crucial-for the absurd man the differences between these lives are best understood morally. The various lives possible for human beings are not simply equivalent. They can be ranked as better and worse. The most obvious example of this type of ranking in The Myth of Sisyphus is this: though the absurd man does not live the best life possible for a human being, Camus clearly thinks he lives a better life than do the existentialists and Christians with whom he compares him. Broadly speaking, for Camus the most striking evidence of the absurd man's superiority to these others is his passion for what is "true," his hatred of "falsehood," and his willingness to face up to reality as it is given to him, in short, his virtue. ${ }^{83}$

For the absurd man, the absurd is a disorder, a sense of meaninglessness in human life, caused by a divorce between human being and a reality that transcends it. That is the absurd in its "pure state" (état pur) ${ }^{84}$ This account is first and foremost part of the absurd man's effort to clarify the nature of the experience from which he suffers. However, it also has a critical purpose. First, it is an explicit criticism of Sartre's claim in Nausea that the absurd is "absolute," that it does not involve a misrelation or divorce of any kind, but 
$\mathrm{Ph} . \mathrm{D}$. Thesis - R. Srigley McMaster - Religious Studies rather is the "fundamental, primordial quality of Existence." ${ }^{.85}$ Second, it challenges the Christian teaching that the world and human life can be experienced as meaningful only if one believes that Jesus is God and accepts the notion of a future life, and hence the corresponding claim that if one does not accept this Christian teaching one cannot experience any of these things as meaningful (the absurd). This is the third stage of the absurd man's analysis.

Consider first his discussion of Kierkegaard. A brief outline of Kierkegaard's account of the absurd will help to clarify the absurd man's assessment of it. We know from his books that Kierkegaard uses the term "absurd" technically to describe only the Christian teaching of the incarnation, the identity of Jesus and God. Kierkegaard writes: "What is the absurd? The absurd is - that the eternal truth has come into being in time, that God has come into being, has been born, has grown up, and so forth, precisely like any other individual human being, quite indistinguishable from other individuals. ${ }^{986}$ For Kierkegaard, the incarnation - the identity of Jesus and God - is, objectively speaking, "an absurdity to the understanding." ${ }^{87}$ In other words, though somehow true, it is nonetheless inaccessible to human beings through the natural exercise of their capacity for intelligence or reason. As Kierkegaard has it, it is an "offense" to the natural man's understanding ${ }^{88}$ Any effort to explain this absurdity is therefore merely a misunderstanding, a futile attempt to water down its absolute character in favour of the notion that it is somehow knowable, or at least partially knowable. ${ }^{89}$ Contrary to such 
Ph.D. Thesis - R. Srigley McMaster - Religious Studies efforts, Kierkegaard is adamant in his claim that the absurd, the incarnation, is absolutely unknowable. This is why faith - the leap - is necessary. And what is faith? In a word, faith is precisely this objective absurdity "held fast in the passion of inwardness." point is therefore not to overcome the absurd, but to believe it. ${ }^{91}$

The reason why Kierkegaard considers belief in these teachings to be necessary is a familiar aspect of Christianity. As he explains the matter, with the advent of Christianity there occurred a radical "breach" between God and the world. ${ }^{92}$ Because of this breach no "direct" relationship between human being and God was henceforth possible. Nor was any indirect relationship to God through the world possible. Regarding the latter type of relationship, Kierkegaard writes: "Nature, the totality of created things, is the work of God. And yet God is not there..." And again: "Nature is, indeed, the work of God, but only the handiwork is present, not God. ${ }^{993}$ Regarding the former type of relationship, Kierkegaard argues that any claim to such a direct experience of God is in fact a form of "idolatry" - not an experience of God at all but an impious identification of God with some merely finite or apparent reality. ${ }^{94}$ According to Kierkegaard this is the true nature of all paganism, and perhaps of all non-Christian forms of thought that concern themselves with such things: the idolatrous claim "that God is related to man directly," or in slightly different words, the notion that human beings can experience directly not only the world as it appears but also its substance or meaning. ${ }^{95}$

For Kierkegaard the breach between God and the world that occurred in the wake 
Ph.D. Thesis - R. Srigley McMaster - Religious Studies of Christianity has both an approbative and a disapprobative meaning. He says that with the breach a new and disturbing possibility was introduced into human life: namely, it became possible for human beings to be 'left altogether 'without God in the world,' in a sense impossible in paganism, which did have the untrue relationship of paganism," that is to say, an idolatrous one.$^{96}$ In other words, God is the world's substance or meaning, but due to the breach between God and world that meaning is no longer accessible to human beings through the normal exercise of their given capacities. Hence the possibility of being left with a world altogether without meaning. However, Kierkegaard also argues that this same absolute separation of God and world established the necessary conditions for a proper relationship to God. "Only after the breach has taken place can there be any question of a true God-relationship." 97 This amounts to the notion that only after it has become impossible to have any relationship to God whatsoever, whether indirectly through the world or directly, does a true God-relationship become possible. As we have seen, for Kierkegaard the condition for that relationship is acceptance of the Christian teachings of the incarnation and resurrection of Jesus. Only after this condition has been met does it become "possible to see God everywhere." ${ }^{\text {"I }}$ It is the sole means by which the breach may be overcome.

In light of this brief outline of Kierkegaard's account of the absurd we can see that the general structure of the problem as he understands it is the same as it is for the absurd man. The fundamental question concerns one's relationship to reality in all its 
Ph.D. Thesis - R. Srigley McMaster - Religious Studies dimensions, how that relationship is best understood and cultivated and how it may be lost or corrupted. That is where the sameness ends, however. First the obvious difference. For the absurd man the absurd is a divorce from reality that can be experienced as such immediately and that may be overcome directly through the proper exercise of one's natural human capacities. Not so for Kierkegaard. Though he does say that the experience of meaninglessness or "despair" stems from a "misrelation" to reality, unlike the absurd man he claims that that misrelation is absolute when considered from the standpoint of our natural capacities. ${ }^{99}$ It cannot, therefore, be overcome by exercising these capacities properly, but only by believing something that is contrary to what they teach; namely, that a man, Jesus, is also the God, and that he rose from the dead.

The operation that underlies these teachings is for the absurd man something very close to intellectual dishonesty. ${ }^{100}$ That operation, if not its distinctively Christian form, is so familiar to our ears today that its true character may not be immediately evident. It requires some explanation. But first the absurd man's objection to the teachings themselves. ${ }^{101}$

The Christian claim that one can experience the world as meaningful only if one first believes that Jesus is God is tantamount to the notion that the world itself has no natural order or meaning. Apologetically the formulation has its reason. If the world were to have its own meaning, or to use the words of Kierkegaard's Christian account, if God were present to human beings both indirectly through the world and directly, then the 
Ph.D. Thesis - R. Srigley McMaster - Religious Studies claim that God is uniquely, and indeed exclusively, manifest in the person of Jesus would make no sense. Be that as it may. The teaching's primary effect is to siphon meaning from the world only to reintroduce it in the form of a doctrine about the identity of a man and God. Now, when this doctrine is coupled with the notion of a resurrection to "another life" - and not just Jesus' but that of all human beings - the sense that the world is meaningless is not only confirmed - it is aggravated exponentially. What can this life be, even when "it is overflowing with health and vigour"," in comparison with an eternal, future life ${ }^{102}$

For the absurd man these Christian teachings encourage, each in its own way, the notion that there are two distinct orders of reality, two worlds, as it were, this world and the "other world." 103 In such an account the other world inevitably becomes the true locus of meaning for human beings, while "this world" becomes a realm of mere appearances or phenomena lacking any inherent substance or value of its own. And this has important consequences for how one understands life in all of its dimensions. In light of this account, all the events, all the experiences of life (including the experience of the absurd) admit of two different explanations or meanings: what they are as they appear to the mind naturally; and what they are taken to be in relation to the other world.

The way these formulations work themselves out in the case of particular experiences is obvious enough. They allow Kierkegaard to say, for example, that death, the cessation of human life and its hopes, "implies infinitely more hope than life implies 
Ph.D. Thesis - R. Srigley McMaster - Religious Studies for us'," or that " "earthly hope must be killed; only then can one be saved by true hope.$" 104$ In "this world" hope remains what it is - a permanent desire for improvement. But when considered in light of the other world, this hope becomes something very different. It is no longer that reasonable though difficult effort to improve one's life, balanced always by the possibility of failure and death, but a sinful desire that prevents one from being saved by true hope. Both meanings are necessary for these "polemical games" (jeux polémiques) to appear to have any real force. ${ }^{105}$

According to the absurd man, the same type of operation is evident in Kierkegaard's account of the absurd. For the "natural" man the absurd is and must be a problem of reason, of the mind's inability to come into contact with reality by exercising its capacity to understand what it experiences. That is all the natural man has, and indeed all that any human being has who remains outside the Christian revelation. However, in relation to what the absurd man calls "Kierkegaard's apocalypse," his other world, this "desire for clarity must be given up if it wants to be satisfied." "Wanting to know" is a sin, because the condition for truly seeing things aright, for knowing them, is faith. ${ }^{107}$ Here the difficult and disturbing experience of not knowing things one can know somehow miraculously becomes both absolute and a great good, while the natural effort to overcome such an experience becomes both impossible and a sin - that is to say, something bad. As the absurd describes the operation: "I know [the absurd] implies ignorance and obscurity; and I am assured that this ignorance explains everything and that 
Ph.D. Thesis - R. Srigley McMaster - Religious Studies

this darkness is my light."108

Neither this darkness nor this light truly is what it claims to be, however. For the absurd man the darkness of the absurd as it is understood by existentialists like Kierkegaard is "born under closed eyelids and through the mere will of man." It is a "dark, impenetrable night that the mind calls up in order to plunge into it." Its false absoluteness stems from this fact: it is born of a desire not to see things as they are. Contrary to the existentialists, the absurd man says that "if [the mind] must encounter a night, let it be rather that of despair that remains lucid - polar night, vigil of the mind whence will arise perhaps that white and virginal brightness which outlines everything object in the light of the intelligence."109 The absurd man's image of the darkness of the absurd as part of the natural rhythm of day and night indicates two things. First, it indicates that darkness is darkness and light is light, and that the two, in the interest of clarity, should never be conflated. The absurd has one meaning, not two. Second, it indicates that the absurd is not absolute. The darkness of night is never complete - one can always see something; and it is never final - as bleak as it may be, day always comes. Operations of the type we find in Kierkegaard may be appealing to some ears because they give the impression of great mystery. This may be precisely their strength. Intractable problems and great sufferings are somehow miraculously transformed into redemptive unities and certain recoveries through the mere utterance of a hope. To the absurd man, however, things look differently. For him there is no genuine mystery here. 
Ph.D. Thesis - R. Srigley McMaster - Religious Studies

He considers all such operations to be merely a "conjuror's emotional trick" (tour pathétique de jongleur) whereby natural human aspirations toward improvement are exacerbated, all the better to relieve them with false promises of perfection. ${ }^{110}$ For Kierkegaard there is this world, without any inherent meaning and hence inaccessible to the understanding; but there is also the other world; and that world, that meaning can be achieved only through the "leap," or in simpler words, through "'the sacrifice of the intellect'."'11

With the exception of Husserl, all the "existentialists" discussed explicitly and at length in The Myth of Sisyphus are either Christians (Kierkegaard, Dostoevsky) or those who are sympathetic to a Christian understanding of the absurd and the nature of meaning (Jaspers, Chestov, Kafka). Yet Camus himself said on numerous occasions that his analysis is also a criticism of Sartre's "atheistic existentialism" (existentialisme athée). ${ }^{112}$ Though in these later comments Camus would have had before him works like Being and Nothingness and Existentialism and Humanism, when writing The Myth of Sisyphus the object of his analysis would have been Sartre's first book, Nausea. This is the work in which Sartre first formulated his modern, existentialist account of the absurd. What is Camus's criticism of this account, and how is it related to his criticism of Kierkegaard's Christian understanding of the absurd?

Though the absurd man is aware of the differences between Christian accounts of 
Ph.D. Thesis - R. Srigley McMaster - Religious Studies

the absurd like Kierkegaard's and modern accounts like Sartre's, nonetheless he refers to them both as types of existentialism. This lack of terminological differentiation is not inadvertent. It has its intended, critical purpose. That purpose is to indicate that, for the absurd man, Christians and modern existentialists share a "common climate" (climat commun) or "spiritual landscape" (paysages spirituels) with regard to their understanding of the absurd that differs fundamentally from his own "ancient" (antique) account of the absurd as a divorce from reality. ${ }^{113}$ The absurd man describes the similarity between Christians and existentialists in this way:

Within the limits of the human condition, what greater hope than the hope that allows an escape from that condition? As I see once more, existential thought, contrary to current opinion, is steeped in an immoderate hope, the same hope that, with the advent of primitive Christianity and the announcement of the good news, inflamed the ancient world. ${ }^{114}$

This bold claim amounts to the notion that distinctively modern forms of thought such as existentialism do not, as their adherents so emphatically claim, involve a radical break with Christianity, but somehow originate in Christianity and continue its project. In The Myth of Sisyphus, the absurd man argues that the best evidence of this continuity is their shared desire "to escape" (échapper) the "human condition" (condition humaine) itself, that is to say, not to overcome the absurd properly speaking, but to be free of a life in which disorders like the absurd (and not only the absurd) are permanent possibilities. ${ }^{115}$ The absurd man's argument regarding this continuity will become clearer if we consider it in light of what Sartre says about the nature of the absurd in Nausea. ${ }^{116}$ 
Ph.D. Thesis - R. Srigley McMaster - Religious Studies In Nausea, Sartre's main character, Roquentin, does not speak of the absurd as a divorce or misrelation between human being and reality at all. He admits that misrelations do occur in "the tiny coloured world of men," but he says that these do not interest him. Such misrelations are only "relatively absurd." To the contrary, the absurd that interests him is "absolute." And he claims that this absolute or fundamental absurdity is the "key to Existence" itself. It is also the key to his "Nauseas." 117 The meaning of Roquentin's extreme formulation becomes clear as his analysis unfolds.

After his encounter with the chestnut tree, Roquentin concludes that the world of "existants" is utterly "devoid of meaning." 118 Here the word "existants" denotes merely the world as it appears to us with all its contents. It signifies "this world," as it were, the common sense world that is immediately present to all human beings, Roquentin included. But Roquentin has a very strange reaction to this world - it makes him sick. Everything he experiences - trees, stones, himself, other human beings - first passes through a stage of nauseating ugliness finally to become something very close to a nightmare. The problem here is not merely the bourgeois ugliness of Bouville; it is not just a particular type of life that nauseates Roquentin, but human life itself, the world itself. ${ }^{119}$ As we have seen this is the inevitable emotional and intellectual consequence in a world that has been reduced to empty appearances or facts.

For Roquentin, all this culminates in the notion that "existing" is itself a "sin." But if existence is a sin, what is one to do? Suicide suggests itself, but Roquentin has 
Ph.D. Thesis - R. Srigley McMaster - Religious Studies already argued that this would not allow him truly to wash himself of the "sin of existing." ${ }^{20}$ As he says, even if he were dead he would still be "In the way, [his] corpse, [his] blood on these stones, between these plants, at the back of this smiling garden." ${ }^{121}$ In order to lend plausibility to his desire to escape existence altogether, but also to avoid the undesirable conclusion of suicide, Roquentin employs a familiar gnostic device. He describes himself in this way: "there was a poor man who got into the wrong world." The world as we all experience it is the wrong world. But "beyond" or "behind" this world there lies another world - what Roquentin calls "Existence." However, Existence, Roquentin's other world, has no definable content. He says that "It is," but also that it "does not exist." 122 The hidden or secret meaning that underlies appearances is therefore not something, but nothingness or the void.

The way Roquentin proposes to overcome the absurd is consistent with these formulations. In order "to be" he must "drive existence out of [himself]."123 He decides that the best way to do so is to write a book-but of a particular kind. Most books are written in order to illuminate the things we experience through the use of words and symbols. Roquentin's book has a very different purpose: it will be about "something that would not exist" and will aim to "make people ashamed of their existence."124 In plain words: in order "to be," to gain substance, Roquentin must first reduce all reality to nothingness imaginatively in speech.

Though in Sartre's book the experience of meaninglessness has become 
Ph.D. Thesis - R. Srigley McMaster - Religious Studies considerably more aggressive than what we find in Kierkegaard's Christian account of the absurd, the absurd man argues that in both cases the nature of the problem is essentially the same. Both accounts belie a kind of "excess" (démesure), a lack of measure in their understanding of the experience. ${ }^{125}$ They make the sense of meaninglessness that is possible in human life (the absurd) seem to be worse than it is (absolute) so as to encourage extravagant solutions in which life will be made better than it can be (perfect). And in both cases the way in which that perfection is achieved is unrelated to the normal exercise of one's given capacities for understanding and relating to reality. In Kierkegaard's account it is achieved through a belief in Jesus as God and the resurrection; for Sartre it is achieved through the action of writing a book aimed at driving existence into nothingness so it can then be recreated in speech in a way that is more to one's liking. In both instances the meaning that is said to be achieved is beyond all reasonable judgement. One can know it only if one takes "the leap."

The consequences of such formulations are not benign. The abiding question of suicide in The Myth of Sisyphus is not merely a foil for the absurd man's analysis; it is intended to convey the true character of all existentialist accounts human life. The absurd man's strong claim is that for existentialists the loss of contact with reality's meaning or substance ends in violence. There are two types. First there is the violence of suicide plain and simple. For the absurd man this action is an attempt to escape the absurd by making one of its "terms" - human being - disappear physically through death. ${ }^{126}$ Of course, none 
Ph.D. Thesis - R. Srigley McMaster - Religious Studies of the existentialists he discusses recommends suicide in this sense. However, they do encourage another type - what the absurd man calls intellectual or "philosophical suicide." ${ }^{\prime 27}$ This is an attempt to escape the absurd either by negating the mind's natural desire to know the greater reality in which it exists, or by negating the greater reality itself, or as is most often the case, by performing both actions simultaneously. At all events, the effort to overcome the absurd in this way requires that the mind do violence to what it knows and experiences of things directly.

Sartre's analysis is a case in point. Roquentin negates all forms of transcendence - not just God, but all realities that are greater than him - world, society, and human being. In place of these realities (existants) Roquentin substitutes Existence - that is to say, nothingness. But a nothingness of this order is not achieved without effort. Roquentin must actively undertake the task of "driving existence out" of the realities that are massively present to him, his own reality included. The consequence of such operations is that the mind and the world no longer have any substantive order at all. Normal judgements about what the world (existants) is like and about how a given life may be made better here give way to fantastic operations (leaps) performed in the void whereby one hopes to regain the substance one has lost. The mind is no longer at grips with anything but its own unbridled will.

The absurd man claims to find the same type of operation in the works of Kierkegaard and Kafka. Consider what he says about Kafka's hero in The Castle: "That 
Ph.D. Thesis - R. Srigley McMaster - Religious Studies stranger who asks the Castle to adopt him is at the end of his voyage a little more exiled because this time he is unfaithful to himself, forsaking morality, logic, and the truths of the mind [morale, logique et vérités de l'esprit] in order to enter, endowed solely with his mad hope, the desert of divine grace." ${ }^{\text {228 }}$ Doing violence to one's soul in this way disorders one's judgement about the things one does experience in the world, one's moral judgements as much as one's judgements about what is true and false. That disorder does not, according to the absurd man, lead to an experience of divine grace, but instead merely increases the degree to which one is exiled from reality. Moreover, it leads one to speak improperly about the world generally, and about the gods particularly. For instance, in the above passage the phrase "desert of divine grace" is not intended as a criticism of the divine per se, but only of speech about the divine that he considers unfitting and perhaps even blasphemous. Consider once again what the absurd man says about The Castle: "The Land Surveyor's last attempt is to recapture God through what negates him, to recognize him, not according to our categories of goodness and beauty but behind the empty and hideous aspects of his indifference, of his injustice, and of his hatred."129

The absurd man finds the same type of speech, and hence the same disordered judgement, in Kierkegaard. He writes: "Kierkegaard wants to be cured...An all the more desperate effort since he intermittently perceives its vanity when he speaks of himself, as if neither fear of God nor piety were capable of bringing him to peace." The absurd man finds evidence of this lack of piety in the fact that Kierkegaard, like Kafka, is willing to 
Ph.D. Thesis - R. Srigley McMaster - Religious Studies concede that God himself may be "unjust, incoherent, and incomprehensible." The problem here is not, to repeat, the question of God's existence. Rather, what is at issue is an operation by which the gods or God are deprived of any substantial order. According to the absurd man the undesirable consequence of that operation is that it causes the mind, too, to lose its order. It reveals "an almost wilful mutilation of the soul in face of the mutilation accepted in regard to the absurd." Once the soul has become disordered in this way, anything is possible. As the absurd man says: if "nothing is proved, everything can be proved." 130

The truth the absurd man discovers through the awakening of the absurd is that he is "at grips with a reality that transcends [him]" in various ways. ${ }^{131}$ That, of course, is not a "solution" to the meaninglessness the absurd man experiences, properly speaking. Yet there is good reason to think that, within the limits set by The Myth of Sisyphus, if any meaning in life is to be found at all, it will be found through an effort of this type.

Moreover, if this effort is best understood as an erotic activity, as the absurd man suggests it is, then the absurd man's account might be tantamount to the notion that reality is an order of love, a play of erotic forces in which meaning is either found or lost, and life is either cultivated or corrupted. The difference between the absurd man's account of the absurd and that of the existentialists is nowhere greater than here. The task of remaining at grips with a transcendent reality in this way is simply not the same thing as trying to 
Ph.D. Thesis - R. Srigley McMaster - Religious Studies transcend that reality in speech by means of some supposed total explanation. Modern thought notwithstanding, total explanations - absolutes of any kind - are both unerotic and the opposite of a genuine experience of and openness to transcendence. Far from explaining anything, the absurd man claims that the result, and perhaps even the aim of such absolutes is to diminish the stature of the greater reality with which he is at grips. Such procedures are not idiosyncratic, as we have seen. Efforts to diminish the greater reality in which all human beings exist are usually accompanied by a corresponding effort to increase the small share of reality that human beings have beyond what is given. Witness only Roquentin's overweening desire "to $b e$ " and Kierkegaard's and Dostoevsky's certainty about a future life in the "other world." This is the reason for the absurd man's constant emphasis on death. Death reveals more forcefully than anything else in human life the very limited share of existence that human beings have. For instance, in direct contrast to Roquentin, it teaches the absurd man that he is not free "to be." ${ }^{132}$ It also reveals a dead point of not-knowing in human understanding: no one knows what death is, and hence no one knows ultimately what life is. Total explanations that posit a life beyond the order of the greater reality in which human beings exist are therefore merely false attempts to transcend, in speech and ultimately in deed, two of this reality's fundamental features: human mortality and that dead point of not-knowing that lies at the heart of human life. ${ }^{133}$

The absurd man's assessment of such explanations is very different from those we 
Ph.D. Thesis - R. Srigley McMaster - Religious Studies might expect from their adherents. Rather than making life more meaningful, he argues that their main consequence is "to impoverish that reality whose inhumanity constitutes man's grandeur [grandeur]," thereby "impoverishing man himself." He writes: "I understand then why the doctrines that explain everything to me also debilitate me at the same time. They relieve me of the weight of my life and yet I know that I must carry it alone. ${ }^{134}$ The way in which total explanations of this type impoverish both human beings and the greater reality with which they exist is perhaps clearest in the case of the Christian notion of a future life: any substantial and purportedly true account of an after life will tend to shift the burden of meaning from "this world" to the anticipated "other world."135 This world will then become a realm of mere appearances lacking any inherent meaning or substance of its own. And as with the world, so too with human being. The difficult and constant effort recommended by the absurd man to remain at grips with the world, to seek to understand it and to live well within it by exercising one's natural capacities, will seem at best merely a preparatory activity by means of which one hopes to "deserve" (mériter) "another life" and at worst utterly futile, perhaps even a sin. ${ }^{136}$ As he has it, one will in this way be relieved of the true "weight" of one's life, we might say of its substance or meaning.

All commentators overlook the fact that The Myth of Sisyphus concludes in a very odd way: namely, with a myth about an afterlife. The oddness of this conclusion stems from the fact that one of the mainstays of the absurd man's argument has been that both 
Ph.D. Thesis - R. Srigley McMaster - Religious Studies

Christians and moderns have become disordered precisely through their immoderate desire or hope for "another life." What are we to make of this?

First of all, the absurd man understands what he is doing. He is telling a story or myth; he is not describing an actual state of affairs after death that he claims to know is somehow true. ${ }^{137}$ His aim in telling that myth is twofold: first, he wants to offer an alternative to other, competing accounts of the after life current in his time that have elements built into them that are inherently disordering, the Christian account primarily. Second, he uses the myth further to evoke and to shed light on the type of life in "this world" that he has been attempting to describe throughout The Myth of Sisyphus, the life of the absurd man. Sisyphus is "the absurd hero," but he is just as much "the workman of today [who] works every day in his life at the same tasks and [whose] fate is no less absurd."138

Consider the basic features of the story and how it differs from the Christian account. As in most Greek accounts of the after life, in the absurd man's myth Hades is the common fate of all human beings after death. In contrast to those who claim that there is a "higher destiny" (destinée supérieure) awaiting some human beings, the absurd man says that "there is only one" destiny for all human beings. This common destiny is simply given. Though the myth does suggest that one may come to hades prematurely - either because one is being punished by the gods or perhaps simply because one prefers to be there, to give only two examples - death itself is a "fate" (destin), not a punishment or a 
Ph.D. Thesis - R. Srigley McMaster - Religious Studies choice. ${ }^{139}$ In other words, just as no one deserves to live, no one deserves to die, properly speaking. Both are simply given for human beings.

Another related aspect of the myth is that it makes no mention of a final state of perfection that the good receive as a reward for their lives in this world, whether it be heaven or the isle of the blessed. The absence of such a state from the absurd man's myth is, I think, both intentional and telling. All accounts of such a final state attempt to depict, each in their own way, a type of healing or salvation of the soul. In that very precise and limited sense they share something in common with the absurd man's desire to be healed of the sickness he suffers. The difference is that for the absurd man life is not a sickness. The absurd as he understands it is not a problem with life itself as we commonly experience it, so the need for healing that accompanies it never manifests itself as a desire for a final or absolute perfection in the other world. Despite the various sufferings and disorders possible within it, the world is nonetheless not a place from which one needs to be saved.

The absurd man's resistance to the conception of any kind of final state in an after life is evident in his depiction of Sisyphus' life in the underworld. Though some of his remarks do suggest that Sisyphus' punishment is eternal, the details of his description of that punishment clearly indicate that it not. It is not, for instance, eternal damnation in the Christian sense. Even in hades Sisyphus experiences the whole range of things available to all human beings. He feels "joy" and "sorrow," he can hear the "wondering little voices 
Ph.D. Thesis - R. Srigley McMaster - Religious Studies of earth rise up," and he sees the "faces" of other human beings, which means that he is not alone. Moreover, though his burden is always there waiting for him (and whose is not?), he also has moments of rest during which he can pause to contemplate the course of his life, we might say its meaning. Perhaps more importantly, even the possibility of improvement seems to remain open to him. He is still able to "struggle towards the heights," and this effort seems to him "neither sterile nor futile." 140 Here again we see the truly measured character of the absurd man's account of the absurd. In his other world there is no final or absolute divorce between human being and reality. Moreover, even the punishment Sisyphus endures is not great. The worst that he suffers is to be exhausted and bored (as so many are here and now); and far from debilitating him, all this suffering does is to strengthen his resolve to struggle towards the heights. There is always a chance that things might become better.

The meaning of the myth for life in this world is, I think, fairly obvious. Sisyphus' life in the other world gradually becomes a metaphor for the absurd man's life in this world. The divorce from reality from which the latter suffers is thus a kind of death in life experience. However, as with Sisyphus in hades, that death is not absolute. Life is always there. After his long effort to understand the nature of his condition the absurd man realizes this. He realizes that another type of life is possible - a happy life. And that life is one characterized by a kind of "harmony" both with oneself and with the greater reality in which one exists. ${ }^{141}$ The difference between these two types of lives is not absolute, 
Ph.D. Thesis - R. Srigley McMaster - Religious Studies

however. Here as elsewhere in The Myth of Sisyphus the absurd man underlines the fact that even the best life possible for a human being is not free of disorders like the absurd. Though he has overcome the "phantoms" (fantômes) of meaning that obscured his understanding of reality, and though he has "silenced all the idols [idoles]," he still says that "there is no sun without shadow, and [that] it is essential to know the night."142 A measure of darkness, a measure of separation from reality is thus inescapable for human beings.

The identification of Sisyphus' life in the other world with a type of life in this world is intended to shift the question of the goodness and meaning of life away from a concern with after lives altogether. The reason why the absurd man does this is again fairly obvious. He has already stated in so many words that human beings know nothing about the after life and that it is a good thing they do not. This is obviously a criticism of the Christian notion of a resurrection to a future life. However, it is also a criticism of the notion that death is eternal nothingness, in Sartre's sense of being dead but nonetheless being alive enough to observe in horror one's own corpse (nothingness). Consider, once again, what Roquentin says about death in Nausea:

But even my death would have been In the way. In the way, my corpse, my blood on these stones, between these plants, at the back of this smiling garden. And the decomposed flesh would have been In the way in the earth which would receive bones, at last, cleaned, stripped, peeled, proper and clean as teeth, it would still be In the way: I was In the way for eternity. ${ }^{143}$

The attempt to give death a substantive or true content may lead just as easily to 
Ph.D. Thesis - R. Srigley McMaster - Religious Studies nightmare experiences like Roquentin's as to life-denying notions of a final perfection like those found in Christianity. The absurd man avoids both possibilities because he never turns his fundamental ignorance about death into a content that either denigrates or enhances the order of the world as commonly experience in the present. Indeed, when he discusses notions like nothingness and death at all, he always expresses himself in terms that are very benign. We have seen this in the case of Sisyphus. However, it is also evident throughout the absurd man's analysis. For instance, at one point in his discussion he says that from our perspective in life the notion of our own "nothingness" (néant) means merely the continuation of the world in terms of its basic structure: "In psychological experience of nothingness, it is by consideration of what will happen in 2,000 years that our own nothingness truly takes on meaning. In one of its aspects, nothingness is made up precisely of the sum of lives that will not be ours." 144 Our own death has no definable content because it we have no experience of it. The attempt to speak about it therefore necessarily leads us to talk about things we do experience, things like the constancy and character of human nature, and the constancy and character of the world's fundamental order.

All that one can draw from these remarks is that taken either individually or collectively human beings have only a small share of existence, both of which can be known without any speculation about a possible condition after death. Moreover, the absurd man says that ultimately the notion of our own nothingness "neither adds anything 
Ph.D. Thesis - R. Srigley McMaster - Religious Studies to nor subtracts anything from reality." ${ }^{145}$ In other words, none of this makes any real difference with regard to life as we all experience it now, in present, including what we experience of its moral order. The good that we experience does not rely for its meaning on the notion of our continued existence in the after life; nor does the bad that we experience somehow become good if no such personal survival is guaranteed. As the absurd man says, we must live all these things as they are, and we must do so "for nothing."

Herein lies the absurd man's greatness or nobility. After acknowledging that his aspiration toward the best life will always be bound or limited by the darkness of the absurd, the absurd man repeats a remark by Oedipus, and he calls that remark "sacred" (sacrée) or divine: "I conclude that all is well."146 This is not an empty platitude. For Camus, the absurd man, like Oedipus, is a "tragic" figure. ${ }^{147}$ His tragedy lies precisely in his lucid willingness to face both of these aspects of life without sophistically conjuring away either of them, and without giving way to the temptation to condemn the whole of reality or any of its dimensions. The ability to hold all of these things together, to be equal to them without lying and without weakness, and without counting on another life in which they might be miraculously resolved, is for Camus the only real "point of departure" for a life that is somehow truly divine. ${ }^{148}$

These are remarkable insights, particularly given the climate of opinion in which 
Ph.D. Thesis - R. Srigley McMaster - Religious Studies Camus was working and the complexity of the problems with which he was engaged. But there are a number of confusions here nonetheless. The book successfully analyses both Christian and modern apocalyptic ambitions, it is true. Indeed Camus' understanding of these ambitions is in many ways firmer and more clear-sighted here than it is even in The Rebel. Yet there is a lingering hesitation in The Myth of Sisyphus about the nature of morality or virtue that belies an ongoing confusion about its relationship to the Christian teachings about God and the afterlife and their modern derivations. For Camus apocalyptic escapes or utopias do not give the world meaning but deprive it of the one it already has. In the words of the absurd man they deprive us of the weight of our lives. ${ }^{149}$ So far so good. But his subsequent claim that this weight or meaning is something that we must carry "alone" overstates the matter, as does his further argument that life will be lived all the better if it lacks meaning altogether. ${ }^{150}$ These are the types of claims that commentators who interpret Camus as an existentialist point to as evidence of their reading. That they do not support such a reading I have already shown. But they do indicate a confusion in Camus' account with which he continued to struggle and that he was not able easily to overcome, even in subsequent cyclical books.

To state the confusion simply, the denial of all meaning (even with hesitations) as an antidote to the affirmation of a total meaning, still belies an acceptance of the hegemony of meaning espoused by all totalitarian thinking, whether Christian or modern. No meaning might be safer politically than total meaning, at least for a time. But there is 
Ph.D. Thesis - R. Srigley McMaster - Religious Studies a family resemblance between the two dispositions that strongly suggests forsaking one for the other will not actually allow you to escape the confusions of the household itself. Camus knows this. His constant attempts to speak meaningfully about life, particularly about its moral character, even in the absence of the Christian teaching is ample evidence of this fact. Yet the confusion remains nonetheless, and it has a definite shape or content. Camus understood critically the nature of the Christian apocalyptic account of meaning. What he did not yet understand, at least in the context of The Myth of Sisyphus, is how to speak about meaning in a way that avoided Christianity's assumptions as well as those of its modern detractors. Camus would wait almost ten years before tackling that problem again - in The Rebel. 
Ph.D. Thesis - R. Srigley McMaster - Religious Studies Notes

1. Albert Camus, The Myth of Sisyphus, trans. Justin O'Brien (London: Penguin Books, 1975), 43, 44, 106; Albert Camus, Essais, (Paris: Gallimard, 1965), 129, 192.

2. David Sprintzen, Camus: A Critical Examination (Philadelphia: Temple University Press, 1988), 44.

3. Ibid., 59.

4. Ibid., 15.

5. Bruce Ward, "The Recovery of Helen: Albert Camus's Attempt to Restore the Greek Idea of Nature," Dionysius 14 (1990): 170.

6. Bruce Ward, "Christianity and the Modern Eclipse of Nature," Journal of the American Academy of Religion 63/4 (1995): 830.

7. Ward writes: "Dostoevsky's art poses a yet more pointed challenge to Camus's whole endeavor to overcome the modern eclipse of nature apart from Christianity." Ibid., 838.

8. Ibid., 838.

9. Ibid.

10. David Sprintzen, Camus: A Critical Examination, 275, 278.

11. Ibid., 276.

12. Ibid., 277.

13. Bruce Ward, "Christianity and the Modern Eclipse of Nature," 838. Unlike Sprintzen, who claims that Camus was, in later works like The Rebel, moving toward a type of historicism similar to Marx's, Ward argues that Camus's disagreement with Marx was both principled and insuperable. Ibid., 825-6.

14. I am concerned here only with one side of Ward's comparative study, that is to say, with the objection to Camus's "nature" posed by Christianity. Ward's description of this objection stands despite any possible objection Camus's work might pose for Christianity. 
Ph.D. Thesis - R. Srigley McMaster - Religious Studies

15. Ibid.

16. For a similar assessment of Camus's hellenic account of nature, see André Devaux, "Albert Camus: le christianisme et l'hellénisme," Nouvelle Revue Luxembourgeoise, janvier-avril 1970, 11-30.

17. Ibid., 836 .

18. Albert Camus, The Myth of Sisyphus, 10; Essais, 97

19. Ibid., 110; Essais, 197.

20. Ibid, 43.

21. Ibid., 104, 27, 43; Essais, 191, 113, 128.

22. Ibid., 59, 62, 65; Essais, 143, 146, 150.

23. Ibid., 82-86, 104; Essais, 167-173, 191.

24. Ibid., 83, 106, 104.

25. Ibid., 54; Essais, 139.

26. Ibid., 102; Essais, 188.

27. Ibid., 98.

28. Ibid., 42; Essais, 128.

29. Ibid., 43n.

30. Albert Camus, Lyrical and Critical Essays, ed. Philip Thody, trans. Ellen Conroy Kennedy (New York: Vintage Books, 1970), 345.

\section{Albert Camus, The Myth of Sisyphus, 32.}

32. Camus commented explicitly on this tendency to identify him with his characters and books in his essay, "The Enigma": "The idea that every writer necessarily writes about himself and depicts himself in his books is one of the puerile notions that we have inherited from Romanticism. It is by no means impossible-quite the opposite-that a writer should be interested first and foremost in other people, or his time, or in well- 
Ph.D. Thesis - R. Srigley McMaster - Religious Studies

known myths...A man's works often retrace the story of his nostalgias or his temptations, practically never his own history especially when they claim to be autobiographical." Albert Camus, Lyrical and Critical Essays, 159.

33. "The fact is that if he [the artist] were it [the character], he would not represent, conceive, and express it: a Homer would not have created an Achilles nor a Goethe a Faust if Homer had been an Achilles or Goethe a Faust." Friedrich Nietzsche, On the Genealogy of Morals, trans. Walter Kaufmann (New York: Vintage Books, 1989), III, 4.

34. Albert Camus, The Myth of Sisyphus, 17.

35. Ibid., 10.

36. Ibid., 17.

37. Ibid., 18.

38. Ibid., 18, 25, 15.

39. Ibid., 18-19.

40. Ibid., 13.

41. Ibid.

42. Ibid., 19.

43. Consider only the following passage: "The trees floated. Gushing towards the sky? Or rather a collapse; at any instant I expected to see the tree-trunks shrivel like weary wands, crumple up, fall on the ground in a soft, folded, black heap. They did not want to exist, only they could not help themselves...But at each instant they seemed on the verge of leaving everything there and obliterating themselves." Jean-Paul Sartre, Nausea, trans. Lloyd Alexander (New York: New Directions Publishing Corporation, 1964), 133.

44. Albert Camus, The Myth of Sisyphus, 19-20; Essais, 106.

45. Ibid., 27.

46. Ibid., 19.

47. Ibid., 17, 19, 21, 31. 
Ph.D. Thesis - R. Srigley McMaster - Religious Studies

48. Ibid., 20.

49. Ibid., 20; Essais, 107.

50. Ibid., 20.

51. Ibid.

52. Ibid., 19.

53. Ibid., 26; Essais, 113.

54. Ibid., 34.

55. Ibid., 33.

56. Ibid., 54; Essais, 139.

57. Ibid., 10.

58. Ibid., 10, 19; Essais, 97, 106.

59. Ibid., 13; Essais, 101.

60. Ibid., 21.

61. Ibid., 42, 50, 53, 64 .

62. Ibid., 34-5; Essais, 120-1.

63. Ibid., 50, 62; Essais, 134, 146.

64. Ibid., 81.

65. Ibid., 34, 87, 63; Essais, 138.

66. Ibid., 10, 88; Essais, 97, 174.

67. Ibid., 49.

68. Ibid., 26. 
Ph.D. Thesis - R. Srigley McMaster - Religious Studies

69. Ibid., 32; Essais, 119.

70. Ibid., 90 .

71. Ibid., 51. Though these remarks have their meaning in the context of Camus's analysis, they also involve a criticism of the way Roquentin understands the matter in Sartre's book, Nausea. Roquentin's various efforts to "justify [his] existence" finally lead him to think that he might be able to do so by writing a book. This book has a very peculiar aim: it would be "beautiful and hard as steel and make people ashamed of their existence" $(\mathrm{N}, 178)$. Elsewhere, he says that one of the only ways he is able to escape the nausea, the absurd, is by writing: "The truth is that I can't put down my pen: I think I'm going to have the Nausea and I feel as though I'm delaying it while writing." Jean-Paul Sartre, Nausea, 173.

72. Ibid., $45 \mathrm{n}$.

73. Ibid., 20.

74. Ibid., 31 .

75. Ibid., 89; Essais, 176.

76. Ibid., 52.

77. Ibid., 110.

78. Ibid., 15; Essais, 102.

79. Ibid., 102; Essais, 188.

80. Ibid., 110.

81. Albert Camus, Lyrical and Critical Essays, 200. This remark occurs in one of Camus's early reviews of Sartre's work, "On Jean-Paul Sartre's La Nausée." It is Camus's first attempt to assess critically Sartre's account of the absurd.

82. Albert Camus, The Myth of Sisyphus, 110.

83. Ibid., 43.

84. Ibid., 10: Essais, 97. 
Ph.D. Thesis - R. Srigley McMaster - Religious Studies

85. Sartre, Nausea, 129.

86. Søren Kierkegaard, Concluding Unscientific Postscript, trans. David Swenson \& Walter Lowrie (Princeton: Princeton University Press, 1941), 188.

87. Ibid., 191.

88. Ibid., 518.

89. Ibid., 189.

90. Ibid., 188.

91. Kierkegaard writes: "It is this contradiction which constitutes the absurd, and which can only be believed." Ibid., 189-90.

92. Ibid., 218.

93. Ibid., 220, 218.

94. Ibid., 220.

95. Ibid., 219.

96. Ibid., 220.

97. Ibid., 220, 218.

98. Ibid., 221.

99. Søren Kierkegaard, The Sickness Unto Death, trans. Howard V. Hong \& Edna H. Hong (Princeton: Princeton University Press, 1980), 13-4.

100. Camus writes that the positions of Kierkegaard and Husserl "imply for the absurd man deceit [escamotage] and the mind's retreat before what the mind has brought to light." Albert Camus, The Myth of Sisyphus, 50; Essais, 135.

101. We note at the outset that Camus understood the nature and meaning of these teachings. When he says that Kierkegaard gives "the irrational the appearance and God the attributes of the absurd," and that he "makes the absurd the criterion of the other world," he clearly has in mind the Christian notions of the incarnation and resurrection of 
Jesus. Ibid., 40-1.

102. Albert Camus, The Myth of Sisyphus, 41.

103. Ibid., 40, 106.

104. Ibid., $41,120$.

105. Ibid., 50; Essais, 134.

106. Ibid., 49.

107. Ibid., 50.

108. Ibid., 42.

109. Ibid., 63.

110. Ibid., 37; Essais, 124.

111. Ibid., 40 .

112. Albert Camus, Essais, 1427. In another interview from the same year, Camus said: "Sartre is an existentialist, and the only book of ideas I have published, The Myth of Sisyphus, is directed against the so-called existentialist philosophers. Albert Camus, Lyrical and Critical Essays, 345.

113. Ibid., 32, 110; Essais, 119, 197.

114. Ibid., 121.

115. Ibid., 121; Essais, 209.

116. Camus published a review of Sartre's Nausea in Alger républicain on October 20, 1938. The criticism of Sartre's account of the absurd implicit in The Myth of Sisyphus is more or less the same as what he says in that early review. The difference is that in The Myth of Sisyphus his own understanding of the absurd is clearer, and hence his criticism is more forceful. For an English translation of Camus's review, see Albert Camus, Lyrical and Critical Essays, 199-202.

117. Jean-Paul Sartre, Nausea, 129. 
118. Ibid., 175.

119. Roquentin writes: "The world was so ugly, outside of me, these dirty glasses on the table were so ugly, and the brown stains on the mirror and Madeleine's apron and the friendly look of the gross lover of the patronne, the very existence of the world so ugly that I felt comfortable, at home." Ibid., 174.

120. Ibid., 177 .

121. Ibid., 128.

122. Ibid., 175.

123. Ibid.

124. Ibid., 178.

125. Albert Camus, The Myth of Sisyphus, 41; Essais, 127.

126. Ibid., 34.

127. Ibid., 32.

128. Ibid., 120; Essais, 207.

129. Ibid., 119-120.

130. Ibid., 41.

131. Ibid., 54.

132. Ibid., 56.

133. In later essays like "Helen's Exile," Camus will argue that the admission of this fundamental ignorance is one of the ways in which we might "rejoin the Greeks," and escape the excesses of both Christians and moderns. "It is by acknowledging our ignorance, refusing to be fanatics, recognizing the world's limits and man's, through the faces of those we love, in short, by means of beauty - this is how we may rejoin the Greeks." Albert Camus, Lyrical and Critical Essays, 153.

134. Albert Camus, The Myth of Sisyphus, 54; Essais, 139. 
Ph.D. Thesis - R. Srigley McMaster - Religious Studies

135. Ibid., 106.

136. Ibid., 15; Essais, 102. In his discussion of Kierkegaard, the absurd man says that for the former even "wanting to know" may be a sin. Ibid., 50.

137. Ibid., 108.

138. Ibid., 108-109.

139. Ibid., 110; Essais, 198.

140. Ibid., 109-111.

141. Ibid., 14.

142. Ibid., 104, 110; Essais, 191, 197.

143. Jean-Paul Sartre, Nausea, 128-9.

144. Albert Camus, The Myth of Sisyphus, $61 \mathrm{n} ;$ Essais, $145 \mathrm{n}$.

145. Ibid., $61 \mathrm{n}$.

146. Ibid., 110; Essais, 197.

147. Ibid., 109.

148. Ibid., 10.

149. Ibid., 54.

150. Ibid., 53. 
Ph.D. Thesis - R. Srigley McMaster - Religious Studies

Chapter Two: A History of Rebellion

But this, finally, is the nature of rebellion. For to run away from the enemy is to call upon oneself the fate of one day meeting that enemy in oneself. A rebellion ultimately imitates that which it rebels against, until the rebel comes to understand himself.

Susan Griffin, Pornography and Silence

Anyone who has read The Rebel knows that it is an admirable book. It is admirable because of its penetrating and uncompromising analysis of the nature of modern totalitarianism and modern liberalism, its insight into the metaphysical revolt that underlies these political and intellectual movements, its unwillingness to accept their ascendancy as a fait accompli but instead to resist them in some way, and its rejection of the modern progressivist notion that human nature can and has been changed - for the better. Indeed, one of the great strengths of Camus' analysis is its frank admission that despite our talk of progress, improvement, and saving humanity, we moderns, unlike the ancients, are not serious about the reality these words denote - namely, the cultivation and corruption of human life. Our real ambition lies elsewhere.

Yet The Rebel is also a very puzzling book, because virtually all of the things that Camus here criticizes he also defends, in one form or another, at some point in his analysis. For instance, though he argues that metaphysical rebellion is a "movement by which man protests against his condition and against the whole of creation" and is therefore inherently nihilistic, he also claims that it has a "positive content" and that there is a "truth innate in its origins." And though he argues against the historicist assumption behind this rebellion that human nature can and does change over time, in his own 
Ph.D. Thesis - R. Srigley McMaster - Religious Studies positive account of rebellion he speaks frequently of "humanity's gradually increasing self-awareness," which implies a standard progressivist account of history according to which modern human beings possess a knowledge of the human condition that was not possible for the ancients, and thus differs qualitatively from anything the ancients might have known. ${ }^{2}$ Finally, despite his repeated criticisms of the "indifference" and lack of seriousness of modern human beings toward both good and evil, virtue and vice, at times Camus argues that moderns are in fact more serious about such things than were the ancients, thanks to their greater awareness of the nature of their condition and their keener perception of the gravity of two of its most fundamental and problematic features - "evil and death."3 Paradoxically, when Camus describes moderns in this way, what he usually considers to be the most telling sign of their inferiority to the ancients becomes the source of their superiority to them - namely, the excessive or "metaphysical" nature of their rebellion. ${ }^{4}$

These differing accounts of modernity and modern rebellion contradict one another. Moreover, the brief list of contradictions I have provided is not exhaustive. In addition to those I have mentioned, The Rebel also contains a number of other similarly antithetical pairs of claims. For instance, at times Camus argues that true rebellion in no way involves the negation of "transcendence" or God; yet at other times he says that the "world of rebellion" and the world of "the sacred" are antithetical, and so much so that "the disappearance of one is equivalent to the appearance of the other." A similar 
Ph.D. Thesis - R. Srigley McMaster - Religious Studies contradiction is evident in Camus' account of the relationship between rebellion and values. Much of The Rebel is devoted to establishing that an act of rebellion makes sense only in terms of an order of value that is independent of human will and action. But here also Camus contradicts himself. For only a few pages after making these remarks, Camus writes:

We have already noted the confused values that are called into play by incipient rebellion...But, before going any farther, let us note that the basis of these values is rebellion itself. ${ }^{6}$

Here the values that were earlier said to be "pre-existent to any kind of action" become instead the product of action - the action of rebellion. And that formulation opens the door to the very type of historicism of which Camus' previous account was an explicit criticism:

But it is already worth noting that this concept of values as pre-existent to any kind of action contradicts the purely historical philosophies, in which values are acquired (if they are ever acquired) after the action has been completed. ${ }^{7}$

This contradiction is related to another methodological one. Camus justifies his choice of the experience of rebellion as the best way to explore and understand the nature of modernity by saying that rebellion is "our historic reality," and that "unless we choose to ignore reality, we must find our values in it." Yet a few sentences earlier he suggests that "insurrection is certainly not the sum total of human experience." If our "historic reality" is limited or deficient because of its rejection of certain aspects of "human experience," then how is it possible to rectify that deficiency and to offer a fuller, positive 
Ph.D. Thesis - R. Srigley McMaster - Religious Studies account of life if the limits set by our historic reality's rebellious ambitions are accepted without question? For instance, if the "sum total of human experience" includes the experience of the "sacred," as Camus' remarks imply, then why knowingly accept constraints, historic or otherwise, that exclude on principle that part of the sum total? And why would Camus formulate the fundamental and guiding question of his analysis - "Is it possible to find a rule of conduct outside the sacred [sacré] and its absolute values? That is the question raised by rebellion" - on the basis of this false or at best limited understanding of the nature and scope of human experience, particularly given that he seems ultimately to want to answer it negatively? ${ }^{9}$

Camus justifies his choice of rebellion in another way, not through an appeal to our "historic reality," but by means of a confusing return to the problem of the absurd. As we know from The Myth of Sisyphus, Camus' best account of the absurd is that it is a sense of meaninglessness caused by a divorce between human beings and a greater, transcendent reality. We also know that Camus offers that interpretation as an explicit criticism of the nihilistic, existentialist claim that reality is inherently meaningless. In The Rebel Camus does restate the divorce formulation of the absurd, but he does not pause to work out the consequences of this important insight. ${ }^{10}$ Instead, and in contradiction to his earlier analysis, the existentialist interpretation of the experience that he abandoned in The Myth again resurfaces and is used to justify a very modern (and existentialist) type of rebellion as the "first and only evidence" he has to go on in his exploration of the nature 
Ph.D. Thesis - R. Srigley McMaster - Religious Studies

of modernity and modern rebellion.

I proclaim that I believe in nothing and that everything is absurd, but I cannot doubt the validity of my proclamation and I must at least believe in my protest. The first and only evidence that is supplied me, within the terms of the absurdist experience, is rebellion. Deprived of all knowledge, incited to murder or to consent to murder, all I have at my disposal is this single piece of evidence, which is only reaffirmed by the anguish I suffer. Rebellion is born of the spectacle of irrationality, confronted with an unjust and incomprehensible condition. ${ }^{11}$

And all this effort is expended so that the "values" or greater order of reality that Camus has already recognized as existing through his analysis of the absurd can be discovered once again, from the ground up as it were, only this time by accepting as true or at least originally true the rebellious modern denial that such an order exists. ${ }^{12}$ The price Camus pays for his constant return to this spurious Cartesian reasoning is not small: ${ }^{13}$ it is the neglect of a careful and potentially fruitful analysis of the greater reality and the place of human beings in it that had been prepared for and by his discussion of the absurd, in favour of a series of weak, frequently sophistic arguments that at best posit hypothetically the existence of such an order by exposing the logical contradictions involved in all modern denials of it.

Camus' method turns on the assumption that you can achieve a moderate or measured rebellion against evil by starting out with the extreme or excessive ambitions of metaphysical rebellion, and then by turning over the arguments by which it is justified until the limits it ignores appear and the true "grandeur of its intentions" become clear, that is to say, until its essentially good and moderate nature emerges. ${ }^{14}$ The dialectical 
Ph.D. Thesis - R. Srigley McMaster - Religious Studies optimism of this method contradicts Camus' more sober and straightforward judgements about the nature of metaphysical rebellion, and it does so with some problematic results. For instance, it allows Camus both to condemn metaphysical rebellion because of its violent excesses and its destruction of human life, and to excuse - if not to justify - these same excesses because they somehow attest to a profound or serious desire to overcome suffering and death and to achieve a kind of immortality.

The destruction of man once again affirms man. Terror and concentration camps are the extreme [extrême] means used by man to escape solitude. The thirst for unity must be assuaged, even in the common grave. If men kill one another, it is because they refuse their mortal condition and want immortality for all men. ${ }^{15}$

The simple meaning of this rather unfortunate remark is that political mass murderers too are somehow concerned with the salvation of all human beings. The only problem is that their methods are wrong.

The point of these remarks is not to make Camus out to be the metaphysical rebel he never was, or to imply that at bottom he approved of terror and concentration camps. I think just the opposite is true. In his best account Camus recognizes that the metaphysical rebel's refusal to accept "the suffering imposed by a limited condition [condition]" is a type of madness, simply, and that the end toward which he aspires - "absolute destruction" or "the dark exaltation in which heaven and earth are annihilated" - is antithetical to the true aims of rebellion. ${ }^{16} \mathrm{~A}$ human being who has such excessive desires and who acts on them is simply not the same type of human being as one who does not, 
Ph.D. Thesis - R. Srigley McMaster - Religious Studies and who understands that rebellion against suffering and evil can only ever be limited in scope and hence measured. Camus knows this, but the dialectical character of his argument at times obscures this important insight. No doubt one of his aims in arguing in this way is to resist precisely those modern ideologies that divide human beings into two clearly discernable camps of good and evil. Yet there is still something questionable here. It may be true that even should you fall so low as to become a totalitarian dictator you still cannot erase all traces of good from your soul, or that a person who has run the full gamut of metaphysical rebellion may in time realize the madness of his enterprise. But neither of these things - neither the presence of the good in all lives nor the permanent possibility of recognizing that good and cultivating it - makes these lives good. There is no necessity, logical or otherwise, that the totalitarian dictator will turn the inescapable good of his soul to accoúnt or that the metaphysical rebel will desist from his revolt against "the whole of creation"; $;{ }^{17}$ and there is no hidden goodness or moderation in either of these excessive revolts against the good.

Perhaps the best way to explain the meaning and significance of these various, contradictory claims is to say, in Camus' own words, that they express "the spirit of modernity at variance with the entire ancient world."18 When Camus discusses this opposition explicitly, he leaves no doubt as to which side he is on - that of the ancients. ${ }^{19}$ And he also makes it clear that the differences between moderns and ancients are such that they require one to make a choice between them. Yet as we have seen, there is 
Ph.D. Thesis - R. Srigley McMaster - Religious Studies something about modernity and modern rebellion of which Camus approves, and which exists uneasily alongside his more frequently expressed agreement with the ancients. The purpose of this chapter is to explain the significance of this contradiction in The Rebel, to understand what is at stake in the choice between the ancients and the moderns, what difference a choice between them would make, and why Camus, seemingly against his own better judgement, hesitated in this book to make it

The tendency among Camus' commentators is to take either his critical assessment or his qualified approval of modernity and modern rebellion as the best interpretation of The Rebel. As we have seen, there is a sense in which both interpretations are right in some measure. Some among these commentators, however, also recognize that Camus' analysis is incomplete, if not contradictory, and attempt to explain its incompleteness in some way. Two of the best (though not the most comprehensive) interpretations of this type are those of Georges Bataille and Eric Voegelin. Bataille emphasizes the "excessive," modern nature of Camus' understanding of rebellion, while Voegelin concentrates on his criticisms of modernity and his effort to formulate an alternative to it by returning to a Greek understanding of human life. Both take their preferred reading of Camus' analysis to be compatible with their own work. Yet both have their reservations about Camus' success in carrying it off. Bataille doubts whether Camus was able finally to "extract" the ancient notion of restraint or moderation 
Ph.D. Thesis - R. Srigley McMaster - Religious Studies from the inherently excessive impulse of rebellion; Voegelin doubts whether Camus' return to the pre-Christian and pre-philosophical world of the "Greek myth" was an adequate means whereby to resist and to criticize the excesses of modernity.

The value of Bataille's and Voegelin's discussions is that they bring to light the fundamental issue at the heart of Camus' account of the quarrel between the ancients and the moderns - namely, whether moderns are right in their claim that the world has no inherent moral order and that human life is essentially "nothing but a prolonged fight to the death" in which the weak perish or are subjugated and the strong rule with "absolute power"; or whether the ancients are right in their claim that the world has such an order in which human beings participate by nature, and that human beings gain their humanity and become virtuous by aspiring to that order and lose their humanity and become vicious by arrogantly rebelling against it. ${ }^{20}$ As I have said, Bataille interprets Camus as being closer to the moderns, Voegelin as closer to the ancients. What are their arguments?

Bataille argues that "in the first instance revolt exists in its excessive movement," and that this movement is "beyond measure." ${ }^{\text {21 }}$ He describes the aim of this excessive movement as a "will to exist in a sovereign way." metaphysical. Politically it is a desire to be king, to rule absolutely and thus to be "beyond all laws." And for Bataille, unlike for Aristotle, what is "beyond all laws" is by definition criminal..$^{23}$ Metaphysically, its ambitions are even greater. Here the will to sovereignty aims at "the negation of the limits of the real world."24 This type of negation 
Ph.D. Thesis - R. Srigley McMaster - Religious Studies is possible only in literature or poetry, according to Bataille, or in "appearances," as Camus has it. ${ }^{25}$ In politics "the limits of the real world" are everywhere and inescapable, so that in this arena to achieve sovereignty one must be "realistic," that is to say, criminal or unrestrained by moral scruples. ${ }^{26}$

Given this interpretation of rebellion, Bataille argues that there is in "revolt first of all a particular will toward excess, and that one cannot extract restraint from sovereignty" without it thereby ceasing to be sovereignty. ${ }^{27}$ And he claims that this is the dilemma posed by Camus' analysis of rebellion also. The impulse of the metaphysical rebel is "to deny what limited him, rather than accept a limited existence," even should it require him to rise up against " "creation in its entirety'. ${ }^{.28}$ But if that is the true nature of rebellion for Camus, what could possibly restrain the rebel in his actions? Bataille claims that strictly speaking the answer to this question is nothing, though he acknowledges and shares Camus' belief that such restraint is needed.

The only possible check to the excessive movement of political rebellion that Bataille finds in Camus' analysis is the more or less Hegelian notion that the sovereign (master) knows that his ascendancy is a dead-end, and hence also that he too must be negated (killed) in his turn. But Bataille, like Camus, gives this blind struggle for power a moral sense by making of the master's death a kind of willful sacrifice. Bataille writes: "the modern rebel exists in crime: he kills, but in his turn he accepts that his crime consecrates him to death: he 'accepts dying and paying for a life with a life'." This 
Ph.D. Thesis - R. Srigley McMaster - Religious Studies quotation is taken from Camus' discussion of the Russian terrorist, Kaliayev. Bataille's interpretation of it is a plausible one. The sovereign, or the rebel who aspires to sovereignty, introduces a kind of restraint into the world of power by willingly and consciously paying "with his life for the privileges of mastery."29

But the restraint Bataille finds in this sacrifice is not really a check to the excessive desire for power itself. That excess appears to be the very nature of human life and thus will continue. The master is murdered by the slave who will in turn become the master. The only difference implied by this sacrifice is that the rebel laments or doubts that things should be this way. ${ }^{30}$ But merely to doubt the excesses of one's actions after the fact is not a real form of restraint, and it does not challenge fundamentally the premises of modern rebellion. To take the case of Kaliayev, it may be true, as Camus says, that he "doubted to the end" whether he was right to kill the Grand Duke Sergei; but he did it anyway. And there is something questionable about Camus' claim that this doubt alone, which was too weak to prevent Kaliayev from acting but supposedly strong enough to make him willing to pay for his action with his life, is what allows us to say that he "triumphed over nihilism." ${ }^{\text {"31 }}$ A doubt about the notion that the world is governed by the dialectic of masters and slaves that issues in real consequences only after one has lived and acted according to that dialectic is hardly proof that one has overcome the nihilism of modern rebellion. It seems better to say that what we learn from Kaliayev is this: there is (perhaps) an order of good within which murder is not legitimate, but we must violate 
Ph.D. Thesis - R. Srigley McMaster - Religious Studies that order in the name of necessity, and we are justified in doing so provided we pay for that violation with our lives.

In Bataille's interpretation Camus endorses the excessive ambition of metaphysical rebellion and then tries to deduce from it a type of restraint or moderation. And though he considers Camus' effort both admirable and necessary, he also finds it wanting. But Bataille also says that the main point of his interpretation "could still be considered debatable. One could doubt that Camus' revolt could be confounded with an urge toward sovereignty." ${ }^{32}$ In other words, one could doubt that Camus is in fact defending modern metaphysical rebellion at all, and thus also that the moderation he recommends is somehow derived from such a rebellion.

Voegelin does not merely share Bataille's doubt, he argues that the primary aim of The Rebel is precisely to criticize and to overcome the excesses of modern rebellion in order to return to an essentially Greek understanding of human life. According to Voegelin, for Camus the notion that life is will to sovereignty or power is the consequence of the European intellectual's preoccupation with the "murder of God." Camus understood the meaning of that preoccupation: the murder of God led logically to the murder of man. Voegelin tells us that the great value of Camus' book is that it analysed the character and meaning of this modern rebellion "in such clarity that it had to collapse." I quote from Voegelin's summary of Camus' argument.

The rebel cannot cope with the order of his life and thus replaces the presence of 
Ph.D. Thesis - R. Srigley McMaster - Religious Studies

life by his dream of the future...Instead of the man who lives here and now in the tension toward the [divine] ground, there is the Ego without a present arrogating to himself power over life and death of his fellow beings, under the pretense of justice and politics...The vision of healing: Rebellion has attained its meridian of thought-men refuse to be gods and thus relinquish the unlimited power to inflict death. The new rule of ethics, the sole "original rule of life today": "to learn to live and to die and, in order to be a man, to refuse to be a go". ${ }^{33}$

For Voegelin these things indicate that Camus is seeking to "reverse" not to further the course of modernity and modern rebellion. He is not rebelling against death, he is not seeking an "empty promised land," and he does not deny God so as to assume the position himself. ${ }^{34}$ In short, Camus was rebelling against the rebels.

Voegelin interprets Camus' work as a positive contribution to a larger effort, evident in the works of various writers of the early to mid-twentieth century, to break out of the inherently restrictive and deformative misunderstanding of human life set by modernity, an effort that both encouraged and coincided with Voegelin's own project. ${ }^{35}$ Yet despite his high praise of The Rebel and of Camus' "inexorability in the endeavor for purity as he divests himself of ersatz realities," Voegelin also expresses reservations as to the adequacy of the alternative that Camus offers in place of modernity and modern rebellion. That reservation concerns Camus' return to the world of the Greek myth. A brief summary of Voegelin's own understanding of these things will help to clarify his disagreement with Camus.

Voegelin argues that the world of the Greek myth is a world "full of gods." By this he means not merely ancient polytheism but a sort of "primary experience" of the 
Ph.D. Thesis - R. Srigley McMaster - Religious Studies cosmos in which human beings sense the presence of the divine in all things. Though the understanding of the world and human life implied by this account was more or less faithful to the nature of human experience, Voegelin says it was also limited in an important way. This limitation stems from what he calls variously its "compactness" or "cosmological" form. The meaning of these terms becomes evident in Voegelin's explanation of how they were surpassed. The "cosmos of the primary experience" was eventually dissociated "into the dedivinized world and the divine ground of being." In other words, "the mythical image of reality" as a world full of gods gave way to the better, more differentiated notion of a world without gods on the one hand and a "worldtranscendent God" on the other. In this context Voegelin credits "classical noesis" with the accomplishment of this dissociation, meaning by this the philosophy of Plato and Aristotle. ${ }^{36}$ However, his more common account is that it was Christianity that first differentiated the ancient, mythical account of the world in this way. ${ }^{37}$

The strength of this new, more differentiated insight seems to be that it offers a truer account of the relationship between God and human being than the one found in the Homeric myth. However, when Voegelin describes the misunderstandings and deformations to which the account is susceptible its truth seems to pale by comparison with its very real weaknesses. Indeed, the modern revolt against God and the "loss of reality" that attended it seem to have been precipitated in some fundamental way by Christianity's dedivinization of the world and the sense of homelessness or insecurity that 
Ph.D. Thesis - R. Srigley McMaster - Religious Studies it entails. It also seems to have been largely responsible for the advent of modern apocalyptic hopes of escaping or transforming the world into a utopian paradise. ${ }^{38}$ Yet despite these weaknesses, Voegelin maintains that Christianity's dedivinization of the world amounts to an advance over the ancient experience of the cosmos. Though it reduces "communication with the world-transcendent God" to the uncertain and "tenuous bond of faith," a bond that may "snap easily," nonetheless it is preferable to "the feeling of security in a 'world full of gods'." And to those who might be inclined to question the superiority of such an account, and for precisely these reasons, Voegelin replies that "the lightness of this fabric may prove too heavy a burden for men who lust for massively possessive experience. ${ }^{.39}$ My point here is not to question Voegelin's insight regarding this sentiment itself, which is both sound and one with which I think Camus would agree. The problem concerns its application.

The reason why Voegelin considers Camus' return to the world of the Greek myth to be an only partially successful response to modernity should be clear in light of these remarks. Voegelin acknowledges that Camus' study of the myth may have helped him to experience and to understand in some measure "the mystery of participation that is hidden between God and man. ${ }^{, 40}$ For even though the myth's account of this participation was limited by its cosmological form, nonetheless it "occurred before or beyond the area of [modern] dogmatisms" and its confusions, and thus afforded Camus access to "predogmatic realities of knowledge." ${ }^{.41}$ But he also argues that this "roundabout way" of 
Ph.D. Thesis - R. Srigley McMaster - Religious Studies regenerating a "noetic knowledge of order" belies acceptance of at least one of the postulates of modernity: its misinterpretation and dogmatic rejection of classical philosophy and Christianity, the two best, most differentiated accounts of the relationship between God and human being, according to Voegelin. And he even goes so far as to say that a human being's ability (Camus included) to experience that relationship, not merely to understand it conceptually, "is possible only when in the knowledge of active participation the ratio of this participation is experienced and differentiated"; 4 in other words, only after the classical/Christian differentiation had occurred and only on the condition that one accepts it.

My own reading of The Rebel has more affinity with Voegelin's interpretation than with Bataille's. I share Voegelin's argument that Camus' best insights into the nature of rebellion and the preponderance of his critical analysis together reveal his preference for the ancients over the moderns. Where I disagree with Voegelin is in my argument that Camus' return to the ancients was more qualified and confused than he makes it out to be, and in my different understanding of the reasons for and meaning of that confusion. Briefly, I do not think the confusion evident in Camus' analysis is due to his return to the Greek myth, but to his unwillingness to return to it and to something like the understanding of human life it entails more completely. And I think one of the main reasons why Camus failed in this regard is that he was unwilling, perhaps like Voegelin himself, to work out fully and unambiguously the consequences of his argument that 
Ph.D. Thesis - R. Srigley McMaster - Religious Studies Christianity is the cause of modernity, not a solution or genuine alternative to it, and that its responsibility in this regard lies in its "dedivinization" of the cosmos, among other things. ${ }^{43}$ I argue that this unwillingness and the confusions that caused it are the reasons why Camus continued to endorse, despite his frequent and often penetrating criticisms of Christianity and his own argument for the superiority of the Greeks, a Christian account of the relationships between God, world, and human being that served only to encourage and to justify the very excesses of modern rebellion it was his main intention to criticize and to overcome.

As to the substance of the confusions themselves, at times Camus seems to have accepted the common Christian claim that the Greeks" "wholehearted" acceptance of the order of cosmos and of their small share of existence in it reflects a lack of seriousness regarding the problems of evil and death and the need for human salvation. ${ }^{44}$ When Camus speaks in this way the Christian concern with personal immortality and the modern metaphysical rebel's desire for "complete unity" and the salvation of "Everyone or No one" (Tous ou personne) seem in comparison with the Greeks to reflect an immensely serious concern with these things. ${ }^{45}$ I say at times because when Camus argues in favour of the Greeks, he interprets this Christian cum modern concern with immortality not as evidence of a greater seriousness about salvation at all, but rather as an excessive, disordering, and perhaps even resentful desire to escape the greater order of the cosmos, as Nietzsche argues. ${ }^{46}$ The competition between these different accounts is, as I have said, 
Ph.D. Thesis - R. Srigley McMaster - Religious Studies

the central problem of The Rebel. And what is at stake in this competition is not merely a question of conceptual differentiation, but of the nature of human life in its cultivation and corruption.

In The Myth of Sisyphus Camus explores the nature of modernity by means of a dramatic presentation of the life of a single human being - the absurd man. The Rebel too aims to understand modernity through an analysis of types of lives, but in this work Camus' method of inquiry is slightly different. In The Myth of Sisyphus Camus' historical analysis of modernity is more indirect and frequently subordinate to his history of the life of the absurd man. In The Rebel the historical analysis is much broader and more integrated with the existential concerns that tend to occupy the foreground in The Myth of Sisyphus. Be that as it may. The Rebel is not a history in the neutral modern sense. It is not guided by the distinction between facts and values that is the basis of modern scientific inquiry. It can best be described as "critical history" in Nietzsche's sense. "Only he who is oppressed by a present need, and who wants to throw off this burden at any cost, has need of critical history, that is to say a history that judges and condemns," writes Nietzsche. ${ }^{47}$ This is Camus' situation as he confronts the alternating violence and indifference of modernity. A frequently occurring theme in his books is that we are all inexorably caught up in the drama (or melodrama) of our times. ${ }^{48}$ This is simply one way of expressing the truth that not only are we all in the modern world but the modern world 
Ph.D. Thesis - R. Srigley McMaster - Religious Studies is somehow also in us. ${ }^{49}$ Yet another, equally pervasive theme in his work is that it is possible, through a reasoned but courageous investigation, to bring the thoughts and actions of oneself and one's contemporaries under the judgement of life, to determine the extent to which these thoughts and actions serve life or harm it, and thus to free oneself from one's time in some measure. ${ }^{50}$ This kind of judgement and the freedom it entails is the goal of Camus' critical history of rebellion.

Camus' history covers two main historical periods in the West. The first period extends from the Greeks (broadly speaking) to the rise of Christianity. The second period begins with the French Revolution and ends with the consolidation of modern liberal democratic and totalitarian regimes in the mid-twentieth century. Thematically Camus' historical study of these periods centers around two broad areas of concern: the way human beings have rebelled in thought and in speech; and the way they have rebelled concretely in action and in politics. Camus' familiar analytic terms - "metaphysical" and "historical rebellion" - designate respectively these two areas of human life, though not in their proper order and fulfillment. Camus uses these terms to describe types of rebellion, in thought and in politics, that depart from or exceed the aims of what he calls "true" (vraie) acts of rebellion. ${ }^{51}$

Even a quick reading of The Rebel makes it clear that the bulk of Camus' historical analysis is devoted to understanding the nature of rebellion in modernity. That analysis occupies some two hundred fifty pages of the book while Camus' discussion of 
Ph.D. Thesis - R. Srigley McMaster - Religious Studies the transition from the Greeks to the Christians is given only ten pages, and is by anyone's standards oddly conceived and notably lacking in historical detail. Yet the importance of this discussion for Camus' book as a whole is in no way lessened by its odd character and its sketchy detail. Camus is always checking the sources, always going back to the transition from the Greeks to the Christians in order to explain the nature and meaning of the modern forms of rebellion with which he was confronted. Indeed, he argues that the modern drama he describes "began with the end of the ancient world [monde antique]. ${ }^{.52}$ I discuss Camus' ancient history first, then turn to his history of modern rebellion.

The expressed aim of Camus' history of antiquity is to discover antecedents for and perhaps even the cause of modernity and modern rebellion by exploring changes that occurred in the ancient world. ${ }^{53}$ Sketchy though it may be, this history is as complex and contradictory as are Camus' various assessments of modernity. In the introduction to this chapter I ventured an initial explanation of the various ambiguities and contradictions in Camus' analysis. I said that the primary contradiction in his ancient history lies in his conflicting interpretation of Christianity, and that this contradiction also plays itself out in conflicting interpretations of the Greeks and the Jews on the one hand, and of modernity on the other. I think there are two distinct patterns that emerge from these conflicting interpretations, and that these patterns amount to two different histories of antiquity, 
Ph.D. Thesis - R. Srigley McMaster - Religious Studies

histories that in turn issue in two very different interpretations and assessments of modernity. To speak of there being two different histories in The Rebel is, of course, to use a distinction that Camus himself never does, and thus to sharpen an opposition in the text that he never makes explicit. But that is precisely the point. By means of the distinction, and hopefully without doing violence to the text, I want to bring to light a problem in Camus' history of rebellion that has been little discussed by commentators but that helps to explain the meaning and significance of many confusions and perplexing formulations evident in his analysis.

The basic outlines of these histories can be stated simply. The first is a roughly Christian history of the course of Western civilization, and it is, we might say, the official history of The Rebel, appearing as it does in Camus' first and only extended discussion of the traditions of antiquity. Briefly, here Camus argues that Christianity successfully overcame the problems from which metaphysical rebellion arises. These are the problems of "evil and death" which, though constant in human life, had been exacerbated in the West by the Jewish invention of a radically transcendent personal God who is somehow responsible for everything but whose ways do not correspond to any normal human judgement about what is good and what evil. ${ }^{54}$ The sole textual evidence that Camus offers in support of this claim is the story of Cain and Abel, in which God prefers the latter's sacrifice to the former's "without any convincing motive...and, by so doing, provokes the first murder." ${ }^{255}$ Nonetheless, he argues that herein lies the real source of our 
Ph.D. Thesis - R. Srigley McMaster - Religious Studies

contemporary history.

The history of rebellion, as we are experiencing it today, has far more to do with the children of Cain than with the disciples of Prometheus. In this sense it is the God of the Old Testament who is primarily responsible for mobilizing the forces of rebellion. ${ }^{56}$

Camus argues that Christianity overcomes this Jewish "dedivinization" of the world and its attendant problems by drawing on the Greek notion of "mediation," which it does not merely accept in its original form, but improves by expanding it into the notion of incarnation and by placing that notion at the center of its theodicy. ${ }^{57}$ Camus writes:

[T]he New Testament can be considered as an attempt to answer, in advance, every Cain in the world, by softening the figure of God and by creating an intercessor between God and man. Christ came to solve two major problems, evil and death, which are precisely the problems that preoccupy the rebel. His solution consisted, first, in experiencing them. The god-man suffers, too-with patience." 58

Because the Christian God shares fully in the suffering of his creation, the charge that he is unjust is groundless; and because he does so in order to redeem that creation, so too is the charge that he is indifferent. In a word, unlike the Greek gods and the God of the Jews, the Christian God cares.

In light of their shared emphasis on mediation, Camus claims that Christianity and Hellenism are essentially compatible, only here the edge is given to Christianity because of its greater seriousness about evil and death and its despairing hope of resurrection. ${ }^{59}$ Because they wrongly reject these Christian truths, modern human beings find themselves once again in the "Judaic world," faced with "the implacable face of a God of hate" who 
Ph.D. Thesis - R. Srigley McMaster - Religious Studies is the antithesis of their highest aspirations and who renders any attempt to conceive a satisfying account of evil and death impossible. ${ }^{60}$ However, rather than admit frankly the impasse to which their rebellion against Christianity had led them, moderns instead push ahead in an effort to complete the dedivinization of the world begun by Judaism and overcome by Christianity, by scornfully rejecting all notion of divinity or transcendence. ${ }^{61}$ Yet although moderns deny these things, Camus tells us that the "appetite for divinity in the heart of man" remains nonetheless, for them as much as for the religious writers they ostensibly reject. ${ }^{62}$ Then begins the modern metaphysical rebel's effort to redivinize the world, only this time not by appealing to some old style divinity, but by discovering divinity or meaning in some purely "immanent" phenomenon, whether it be the will of the people, absolute spirit, history, or the will to power. ${ }^{63}$ In each of these cases Camus claims that the modern ambition is essentially the same as the religious one - namely, it is an attempt to achieve a finality of purpose and meaning amidst the corrosive and seemingly forever imperfect movements of human life. ${ }^{64}$

When Camus argues from the standpoint of this first history, he offers a number of different responses to the crisis of modernity and modern rebellion. Though on the surface these responses may seem not only different but even contradictory, if we look at them more closely we can see that they all belie a common acceptance of the Christian understanding of the problem. For instance, sometimes Camus suggests that what is needed in modernity is something very much like a return orthodox Christianity itself, 
Ph.D. Thesis - R. Srigley McMaster - Religious Studies including acceptance of its notion of the "divinity of Christ" and perhaps even its promise of personal immortality ${ }^{65}$ Camus never argues in favour of these Christian teachings explicitly, of course. But he often suggests them indirectly by making provocative, leading remarks about the problems in human life - death, suffering, imperfection - to which they are so obviously an answer and by contrasting the success of this answer to the failure in modernity to find any compelling alternative. ${ }^{66}$ At still other times Camus offers his own version of the mediator - the rebel - who is modeled on the Christian account of Jesus insofar as he plays a mediating role "between God and history," but who differs from him in that he makes no claim to identity with God and holds out no hope for personal immortality ${ }^{67}$ Finally, there are times when Camus seems to abandon altogether the idea that what moderns need is a mediator who will reconcile God and world, in favour of the very modern notion of an immanent, radically dedivinized world in which the aim of human life is to "reconstruct creation itself" in order to give it a meaning or "form it does not have" by nature. ${ }^{68}$

Camus' second history is very different from his first. Its most striking feature is its claim that the problems from which metaphysical rebellion arises were not solved by Christianity but somehow originate in it. Though hints of this second history can be found throughout the pages in which he develops his first history, ${ }^{69}$ Camus states it most clearly and most forcefully when he is describing in detail the nature of modernity and modern rebellion. Here the comparisons between Christianity and modernity begin to arise almost 
Ph.D. Thesis - R. Srigley McMaster - Religious Studies

of their own accord. It seems that the closer Camus comes to describing the nature of modern metaphysical rebellion the more its similarities to Christianity impose themselves. In any event, the main difference is this: the role Camus gives to Judaism in the first history he gives to Christianity in the second. Dedivinization, an apocalyptic history ending in a final judgement, messianism, the denigration of reason to the advantage of faith, all these things Camus here attributes to Christianity rather than to Judaism. ${ }^{70}$ Moreover, the notion that modernity is best understood as a continuation of problems and confusions that are distinctively Jewish also changes. Instead of being the historical fulfillment of Judaism (i.e., a radical and more consistent dedivinization) and a perversion of Christianity, Camus here argues that modernity is the fateful outcome of the Christian dedivinization of the world.

It is the Christian attitude that gradually empties the world of its substance...since the substance resided in a conglomeration of symbols. These symbols are the drama of the divinity, which unfolds throughout time. Nature is only the setting for this drama. ${ }^{71}$

When Camus reasons in this way, not even his argument for the "strength" of the Christian notion of incarnation, which is supposedly the true locus of substance or meaning in history, remains immune from criticism. ${ }^{2}$ Marx's "deification of man" is nothing but the Christian deification of Jesus consistently applied to all human beings; ${ }^{73}$ and despite the disclaimers of his first history, here Camus argues that this deification is inseparable from an apocalyptic messianism of Christian, not Jewish origin that was 
Ph.D. Thesis - R. Srigley McMaster - Religious Studies ultimately appropriated by modern theorists like Hegel, Marx, and Comte and later acted upon by their political successors. "This reconciliation, in any case, is instructive as concerns the Christian origins of all types of historic Messianism, even revolutionary Messianism." ${ }^{.74}$ And to the counter-argument, common among Christians, that despite their phenomenal similarities, the Christian and modern accounts of these things nonetheless differ substantially, Camus replies that "the only difference lies in a change of signs."75 The substance remains the same. "Eternity separates them at the beginning, but the doctrines of history end by reuniting them in a realistic conclusion."76

As I have said, Camus' second history also entails a different understanding and assessment of the Greeks. In his first history Hellenism and Christianity are considered to be compatible because of their shared emphasis on mediation. And though Camus says frequently that in this respect "Christianity is Greek," his argument, as we have seen, often implies just the opposite - that the Greeks at best prefigure a notion that achieved its most complete realization only in Christianity. ${ }^{77}$ In Camus' second history his interpretation of the Greeks changes. First, he argues that the Greek insight into the nature of human life and its relation to the world was not improved or even equaled by Christianity but rather "shattered" by it. "The beautiful $[$ bel $]$ equilibrium between humanity and nature, man's consent to the world, which gives ancient thought its distinction and its refulgence, was first shattered for the benefit of history by Christianity. ${ }^{978}$ In this context Camus means by history a divine providential account of 
Ph.D. Thesis - R. Srigley McMaster - Religious Studies the course of human life that begins with creation and culminates in the final judgement. "The Christians were the first to consider human life and the course of events as a history that is unfolding from a beginning toward an end, in the course of which man achieves his salvation or earns his punishment." "The Greeks imagined the history of the world as cyclical." cyclical may be no less abstract than the idea that it moves in a "straight line," and it might not even be Greek. ${ }^{81}$ Nonetheless, Camus' reason for using the distinction is clear enough. He wants to distinguish between ancient attempts to find meaning in history that emphasize recurrent forms and patterns and Christian and modern accounts of history in which the course of events is understood to be "strictly unique" and in which that uniqueness is carried to its final term in the notion of an absolutely unprecedented apocalyptic kingdom. ${ }^{82}$

This notion of providential history is one way that Christianity "breaks" with the Greeks. ${ }^{83}$ But perhaps the more fundamental break lies in the fact that Christianity "empties the world of its substance," which would seem to be the necessary condition for all apocalyptic notions of the end of history in which that substance will finally be regained and perfection achieved. If this is so then the primary problem with the account is dedivinization, to use Voegelin's term, the radical separation of God and world that is inherent in the Christian distinction between transcendence and immanence. Indeed, Voegelin himself argues that the defining feature of Christian dedivinization is its 
Ph.D. Thesis - R. Srigley McMaster - Religious Studies

apocalyptic aspiration.

By dedivinization shall be meant the historical process in which the culture of polytheism died from experiential atrophy, and human existence in society became reordered through the experience of man's destination, by the grace of the world-transcendent God, toward eternal life in beatific vision. ${ }^{84}$

Of course, for Voegelin this achievement is one of Christianity's chief strengths. It successfully differentiates the human desire for perfection or completion while at the same time accepting the "conditio humana without chiliastic fancies." And as such it is the antithesis of all modern revolutionary expectations of a transformation of the temporal order into a lasting and final state of perfection. ${ }^{86}$

Now Camus argues that this phenomenon is not Greek. The Greeks had gods, and they experienced transcendence, but they did not understand reality to be divided between transcendence and immanence in the Christian sense. As Camus writes, for the Greeks "there were not gods on one side and human beings on the other, but a series of degrees [degrés] leading from one to the other. ${ }^{\$ 87}$ Whatever these degrees might be, they are clearly not mediators in the Christian sense. They indicate a continuity of being ranging from the human to the divine that is characterized by differences but in which these differences are never conceived as absolute. Human beings are never without a relation to the divine and the divine is never separated absolutely from human beings. ${ }^{88}$ And this has very obvious and important implications for the Christian notion of mediation also. If the radical separation of God and world that Camus finds in Christianity is wrong and 
Ph.D. Thesis - R. Srigley McMaster-Religious Studies abstract to begin with, then the Christian attempt to "diminish the distance" between God and world by means of the mediating work of Jesus is not a true solution at all, but merely a continuation of the confusions and distortions of dedivinization at an even greater level of abstraction. Moreover, the falseness of a solution of this type is always in danger of being exposed as such without any comparable clarity being achieved regarding the original misconception from which it derives its meaning. ${ }^{89}$ In that case what will occur is a proliferation of equally "true" solutions to the original "false" problem, that is to say, equally true attempts to redivinize a cosmos that was never truly dedivinized in the first place. Within the limits of Camus' second history this might almost stand as a definition of the nature of modernity. In modernity the exclusivity and finality of divine presence that Christianity had claimed for itself has been superceded by other, more comprehensive claims to finality (totalitarianism), and by more aggressive and violent means of achieving it (terrorism). In this century we have witnessed an unprecedented proliferation of mediators - regimes, ideologies, personalities - all setting themselves up as indispensable to human salvation, and all holding out the promise of an apocalyptic kingdom, the meaning of and the path to which are known only to the mediators themselves. ${ }^{90}$ In this interpretation, mediation, whether in its Christian or modern form, is all of a piece; and its effects are anything but salutary for human life. Indeed, Camus claims that such accounts are closely related to what we now know as terrorism, that is to say, the imposition of "an interminable subjectivity...on others as objectivity," and the 
Ph.D. Thesis - R. Srigley McMaster - Religious Studies physical and psychological forms of torture necessary in order to make that subjectivity compelling. ${ }^{91}$

The types of confusions and contradictions we have seen in Camus' ancient history of rebellion are also present in his modern history. And they are present in a very similar way. Indeed, the same patterns that we witnessed in his analysis of antiquity are repeated in his analysis of modernity. Here again there are two different histories - one Christian, one Greek. And here again those histories contradict one another yet somehow manage to exist uneasily alongside one another. Moreover, the meaning of the contradiction also remains the same, as do Camus' odd ranking and placement of these histories in the body of his analysis. Appearances to the contrary notwithstanding, Camus' official history of modern rebellion is Christian, which perhaps explains why Christian writers have taken such a keen interest in his books, often claiming to have found in them intimations of a conversion to Christianity. ${ }^{92}$ The very structure of the analysis - from the book's chapter titles to its section headings - is organized thematically according to a common Christian interpretation of the stages of secularization in the West from the late eighteenth to the middle twentieth century. The following is my explanation of that history.

In The Rebel Camus explores the nature of modernity as a form of rebellion. In his Christian history of modernity he makes the argument that modern rebellion is best 
Ph.D. Thesis - R. Srigley McMaster - Religious Studies understood as a process of dedivinization in which the notion of God or transcendence is gradually denied in favour of a purely immanent explanation of human life. Though he claims that all moderns affirm and participate in this process of dedivinization, he also says that they do not do so in the same way. In modernity there are both cynics and believers, realists and idealists, nihilists and utopians. Cynical moderns expose the illusory character of traditional moral principles that limit the scope or range of human action. But they do not believe that such a disillusioning will usher in an era of human perfection. They may think that it will make human beings more honest and less susceptible to the influence of princes and prophets. But that is not progress in the modern sense. The believers are another matter. They too deny God or transcendence, and they do so for reasons similar to those of the cynic. They think that such a belief prevents us from seeing the world as it is. But they lack the cynics' moral skepticism and claim instead that once transcendence has been eradicated completely a period of enlightenment will follow that will lead to a moral and political utopia. ${ }^{93}$

In Camus' Christian history of modernity this process of dedivinization has roughly three phases. These phases form the content of his analysis in Parts Two and Three of The Rebel - "Metaphysical" and "Historical Rebellion" respectively. Each phase has both an existential and a political component. The revolutionary changes argued for and defended by philosophers soon found their expression in actual regimes organized by political men and women willing to take philosophers at their word. These changes are 
Ph.D. Thesis - R. Srigley McMaster - Religious Studies apparent in the major political events of eighteenth, nineteenth, and twentieth centuries. Rousseau lays the groundwork for the revolution in France that will ultimately be carried out by men like Saint-Just and Marat; ${ }^{94}$ Hegel and Marx provide the philosophical and political doctrine that will inspire and guide the Russian revolution; and Nietzsche will provide Hitler and the Nazis with a doctrine about the will to power that will encourage them to create a super-humanity free of the old racial and cultural impurities. ${ }^{95}$ The actual chronology of these events does not match Camus' analysis perfectly. Traces of the divinity seem to have lingered on for certain later figures while early ones had rejected it entirely. Nevertheless Camus claims that broadly understood with each successive phase of the progression there occurred a corresponding diminution of the notion of transcendence. 96

The story begins with Rousseau and the French revolutionaries. In prerevolutionary France kings derived their authority from the divinity that established them. “Until Rousseau's time, God created kings, who, in their turn, created peoples." As a consequence of Rousseau's philosophy the traditional order of foundation was inverted. "After The Social Contract, peoples create themselves before creating kings." 97 Though the source of authority shifts from God to the people, the nature or scope of the power that changes hands remains the same. The divinity who once ruled from the heavens will take up residence in the people themselves. Camus argues that Rousseau's use of words like "'absolute,' 'sacred,' 'inviolable"" to describe the general will is evidence of this 
Ph.D. Thesis - R. Srigley McMaster - Religious Studies transfer of divine authority. "The will of the people is primarily the expression of universal reason, which is categorical. The new God is born. ${ }^{.98}$ Despite the remnants of the old divinity that lingered on in the new, the latter promised significant improvements. Instead of exercising power arbitrarily and unjustly, the new divinity was to be both rational and just. ${ }^{99}$

Though the execution of Louis XVI marked "the secularization of our history and the disincarnation of the Christian God,"100 it did not thereby eradicate all notion of transcendence. That final eradication would come later. Though the people are somehow sovereign they must also act in accordance with the dictates of reason, which are eternal. This eternal reason does not rely on God for its legitimacy but it transcends the world nonetheless, as do the virtues associated with it. ${ }^{101}$ "The Supreme Being [i.e., "Reason"]...is only the ancient god disembodied, peremptorily deprived of any connection with the earth, and launched like a balloon into a heaven empty of all transcendent principles." 102 This is what Camus calls the "Religion of Virtue." It marks the beginning of "modern times" and initiates the "era of formal morality."103

The hopes of the revolution were quickly disappointed. The new divinity proved to be as capricious as the old one and even more bloodthirsty. The equation of politics and virtue ${ }^{104}$ coupled with the demand for "absolute purity" created a form of political violence that exceeded that of all previous regimes. Reason, once deprived of its human content, was more murderous than any ancient divinity. Yet as violent as the French 
Ph.D. Thesis - R. Srigley McMaster - Religious Studies revolutionaries were Camus claims that they were still preferable to their successors - the Russian revolutionaries of 1918 . The organizers and theorists of the latter revolution found the bourgeois restraint of their predecessors quaint and outdated in comparison to their own liberation from traditional morality and their political realism. The French avoided the excesses of the Russians in part because they still embraced a divinity of sorts. "They still preserved the Supreme Being. Reason, in a certain way, is still a mediator. It implies a pre-existent order."105 Though having been "dematerialized and reduced to the theoretical existence of a moral principle" that divinity was still irrational enough to provoke the next stage of the critique and to encourage a new generation of revolutionaries who would be even more violent and whose denial of transcendence would be absolute. ${ }^{106}$

According to Camus' Christian history this revolution too began in the academy among philosophers and writers. It continued the dedivinization of the world begun by the French Revolution but not completed by it. The first phase of that dedivinization was the death of the king. This regicide first achieved in speech by Rousseau would later be carried out in deed by French revolutionaries like Saint-Just. Hegel is responsible for completing the second phase of this process of dedivinization. He added to Rousseau's regicide a deicide that eliminated the last vestiges of divine authority on which kings and peoples depended for their power. "Hegel's undeniable originality lies in his definitive destruction of all vertical transcendence - particularly the transcendence of principles."107 
Ph.D. Thesis - R. Srigley McMaster - Religious Studies That deicide will become the animating principle of all subsequent revolutionary regimes. It will empty reason of its formal or universal content by identifying that content with success. ${ }^{108}$ And it will free those who embrace the change from all moral constraints associated with the ancient regime. Camus claims that even those who continue to believe in the utopian ends of the revolution will henceforth be utterly cynical in their methods. ${ }^{109}$

Without transcendence nature died too because nature was understood to have its essence from God. ${ }^{110}$ All that remained therefore was history. But for the revolutionary thinkers of the nineteenth and twentieth centuries history had an appeal all of its own that was perhaps even more important than the one derived from this victory by default. As Camus says toward the end of his discussion of Hegel, "nothing can discourage the appetite for divinity in the heart of man."111 God may have been dead but the desire for him or something like him continued to shape and motivate these revolutionary ambitions. Even if one could no longer look to the heavens for a sense of transcendence one could always look ahead to the future. This is precisely what Hegel and his left wing successors did, according to Camus. Marx merely replaces "the beyond with the later on [l'au-delà par le plus tard]." ${ }^{\prime 12}$ History suited the apocalyptic aspirations of modernity well because it seemed to satisfy the need for transcendence while escaping the natural limitations on human ambition that were intrinsic to earlier theological accounts of that experience. For God all things may have been possible but not for human beings considered independently of that divinity. 
Ph.D. Thesis - R. Srigley McMaster - Religious Studies

The final phase of Camus' Christian history of modernity is the Russian Revolution and its intellectual architects. That event is modernity's final stage in the sense of its last one. Its meaning is articulated in the books of Marx, Engels, and Lenin and its character is manifest concretely in the Soviet regime under Stalin. Camus examines both in order to reach some conclusions about its nature. This is also the place in Camus' analysis where his Christian history begins to break apart and reveal its limitations.

Camus spends some time explaining the ways in which Marx's economic and political theory have failed to account for the facts of modern economic and political organization. He argues that this failure is due primarily to the prophetic character of Marx's work. That prophetic character is an expression of an apocalyptic hope that a new arrangement of the means of production would bring about an economic order in which exploitation and oppression would be eliminated and along with them the need for politics of any kind. ${ }^{113}$ According to Camus this utopian aspiration ignores or overlooks the fact that even were older exploitative relationships to be overcome there is nothing in human experience to suggest that such a change would be permanent. This is the "religious postulate" of Marxist theory and Camus claims that there is no evidence in our experience of politics to anticipate its fulfillment.

The antagonistic terms of a historical situation can negate one another and then be surmounted in a new synthesis. But there is no reason why this new synthesis should be better than the original. Or rather there is only a reason for this 
Ph.D. Thesis - R. Srigley McMaster - Religious Studies

supposition, if one arbitrarily imposes an end to the [Marxist] dialectic, and if one applies a judgement based on outside values. ${ }^{114}$

What lends credibility to Marx's account is not historical evidence but a religious hope on which he draws but for which there is no evidence save the content of that hope itself.

"Can it be said, therefore, that [Marx's] city of ends has a meaning? It has, in terms of the sacred universe, once the religious postulate has been admitted. The world was created, it will have an end; Adam left Eden, humanity must return there."115

All this analysis is fairly familiar. And so too is Camus' assessment of it, at least within the limits of his Christian history. Marx's philosophy simply repeats the main features of the Christian eschatology save for the fact that its divinity is immanent rather than transcendent. Camus finds plenty of evidence for this assertion in the body of Marx's analysis but also in proclamations made by his most ardent supporters. After the failure of the Spartakus movement in Germany Karl Liebknecht writes that

[a]t the crash of economic collapse whose rumblings can already be heard, the sleeping soldiers of the proletariat will awake as at the last fanfare of the Last Judgement, and the corpses of the victims of the struggle will arise and demand an accounting from those who are bowed down with curses. ${ }^{16}$

Liebknecht's iconography is taken straight from the pages of John's apocalypse. ${ }^{117}$ The demand for justice, the notion of divine retribution, resurrection to an after life in which one will witness the punishment of one's enemies - these are the teachings of the Christian eschatology. But more important than Camus' observation of the phenomenal similarities between Marxism and Christianity is his assessment of their respective 
Ph.D. Thesis - R. Srigley McMaster - Religious Studies meanings and motivations. In his Christian history Camus suggests that these similarities are evidence of a need or desire in human nature that is permanent though open to a number of different symbolizations. "'I rebel, therefore we exist,' said the slave. Metaphysical rebellion then added: 'we are alone,' by which we still live today. But if we are alone beneath the empty heavens, if we must die forever, how can we really exist?"'118 Here as elsewhere Camus' own answer to the question is never stated explicitly, which leaves the analysis ambiguous. ${ }^{119}$ Nevertheless the question itself teaches us something about his understanding of human nature. Marxism's answer to the question ${ }^{120}$ may not be an adequate one. But according to the argument of Camus' Christian history it is the right kind of answer. The reason is that it contains the type of apocalyptic content required by the question. Like Christians Marxists and indeed all modern revolutionaries aspire to immortality because that is what their human nature desires. The problem with their accounts is only that they pursue that desire in way that ensures that it will remain unsatisfied.

The other main problem with modern apocalyptic accounts is that their denial of divine transcendence and of human nature deprives them of a meaningful ground for morality. ${ }^{121}$ Their aspiration toward justice is evidence that the desire for such a morality is a permanent feature of human nature just as much as the desire for immortality. But because moderns reject God they empty human justice of its content and so find themselves acting, against their own best intentions, in extraordinarily unjust ways. ${ }^{122}$ The 
Ph.D. Thesis - R. Srigley McMaster - Religious Studies concentration camps have their explanation here. In their misunderstanding of moral goodness and their misplaced desire for purity modern revolutionaries have constructed a false copy of the last judgement here on earth. Regicide, deicide, and finally homicide. Without the restraint and guidance of a transcendent order moderns have set to work eliminating the barriers to human perfection at the price of human life itself.

Such are the findings of Camus' Christian history of modernity. They amount to a fairly conventional critique of the modern project that turns on the assumption that modernity is best understood as a Christian heresy. Moderns continue the Christian teaching but corrupt its content. They do so by immanentizing the Christian eschaton. ${ }^{123}$ But what else can a rebel do? The account permits nothing but orthodox adherence or heretical revolt because its apocalyptic aspirations are taken to be the very essence of human nature. This is also the source of the common origin argument that Camus occasionally uses to explain modernity's excesses and that leads him to some of his more troubling conclusions about the possibly virtuous motives behind concentration camps and mass killing. Not as outcomes of course. Camus was absolutely and resolutely against these things. But as in the case of his ambiguous assessment of Caligula, he seems at times to have entertained the idea that this type of brutality might belie a measure of character and perhaps even a misplaced desire for salvation.

Camus' Greek history offers a very different account of the nature of modernity 
Ph.D. Thesis - R. Srigley McMaster - Religious Studies than does his Christian history. Though traces of the former can be found throughout The Rebel, its most important insights are apparent in Camus' discussion of Marxism and modern totalitarianism in Part III of the book. ${ }^{124}$ In Camus' Christian history totalitarianism is "nothing other than the ancient dream of unity common to both believers and rebels, but projected horizontally onto an earth deprived of God."125 That explanation is a combination of the immanentization and common origin arguments. In Camus' Greek history the account is reversed. "Totality is not unity. The state of siege, even when extended to the very boundaries of the earth, is not reconciliation." ${ }^{\text {"126 }}$ The desire for totality is not equivalent to unity and unity is the aim neither of Christianity nor modernity. What both aspire to is a totality that separates them from the ambitions of the ancients and implicates them in the apocalyptic aspirations of the contemporary world. Camus goes so far as to argue that the spirit of totality was "invented" by Christianity. ${ }^{127}$ In comparison to the Greek world the "unity of the Christian and Marxist world is astonishing." ${ }^{28}$ Both affirm a progressivist account of history; both understand the events of that history to be "strictly unique"129; and both consider the ultimate aim of that progress to be a "transformation" of nature in which the perennial hardships and sufferings of life are overcome. ${ }^{130}$ All this stands opposed to the Greeks. The Greeks had an understanding of history but they did not imagine it to be meaningful in the sense of having a direction. History for them was cyclical, which means that no event was strictly unique. Meaning did not lie in novelty or in unprecedented events as it does for 
Ph.D. Thesis - R. Srigley McMaster - Religious Studies apocalyptic thought but in the movement of life within recurring patterns that were themselves mysterious and hence beyond explanation. Whatever direction history might have was found within that movement, for which the Greeks had constructed a rich and evocative language capable of expressing the full range of human experience. ${ }^{131}$

Unlike his Christian history here Camus does not interpret the similarities between Christianity and Marxism as evidence of a permanent and inescapable desire for perfection. With the Greeks as his measure he argues instead that this desire belies a disproportionate emphasis on human importance that refuses to acknowledge any purpose or meaning that does not match its own perceived self-interest. ${ }^{132}$ Tracking that disproportionate emphasis becomes the central interpretive question of this history and eclipses even the distinction between transcendence and immanence as Camus' chief analytic tool. In his comparison of Marx's immanent and Joseph de Maistre's transcendent historiography Camus says it makes not the slightest difference that Marx was an atheist and Maistre a believer.

From this angle, socialism is therefore an enterprise for the divinization of man and has assumed some of the characteristics of traditional religions. This reconciliation, in any case, is instructive as concerns the Christian origins of all types of historic messianism, even revolutionary messianism. The only difference resides in a change of signs. ${ }^{133}$

What is important is not the fact that one account is transcendent while the other is immanent. The ranking of human and divine elements of life is usually quite fluid and can assume any number of proportions without the existential balance that they typify 
Ph.D. Thesis - R. Srigley McMaster - Religious Studies

being upset. In the case of individual human lives even extreme differences in emphasis do not necessarily result in significant changes of disposition. As Camus writes in his notebooks, "[t]he Greeks made allowances for the divine. But the divine was not everything." 134 The same cannot be said of the desire for totality that underlies the messianic aspirations of both Marx and Maistre. The source of this desire is neither transcendence nor immanence though it distorts our relationship to both areas of reality. Rather it is motivated by a refusal to accept life as it is given that takes the fact of its disaffection as proof that human existence ought to and can be significantly different than it is; and it equates meaning in the fullest sense only with completion or perfection. In terms of our everyday experience this amounts to saying that life will have a meaning only when it is over.

In Camus' Greek history Hellenism is not an earlier proto-typical version of the Christian revelation; and modernity is not a deformation of the Christian teaching that confirms the former's truth while denying its substance. In this account Christianity and modernity are the same thing. What separates them from the Greeks is their desire for totality. The Greek notion of unity is not an ancient form of that desire but its antithesis. What is this unity?

Camus does not define the term in so many words but his various descriptions of the Greeks give us an indication of what he means by it and how it differs from the desire for totality. In contrast to the seamless worlds of historical and divine providence the 
Ph.D. Thesis - R. Srigley McMaster - Religious Studies

Greeks offer us a tragic world in which rebellion is a permanent feature of human life because the sources of rebellion - injustice, misfortune, suffering - are also permanent features of life. The presence of these structures means that things will inevitably go wrong, often badly so. Yet the Greeks never allowed their rebellion against and their disaffection with these aspects of life to extend to the order of the cosmos itself.

To rebel against nature amounted to rebelling against oneself. It was butting one's head against a wall... The acme of excess to the Greek mind was to beat the sea with rods - an act of insanity worthy only of barbarians. ${ }^{135}$

Camus expresses his own experience of this rebellion in similar words: "Poverty kept me from thinking that all was well under the sun and in history; the sun taught me that history was not everything. I wanted to change lives, yes, but not the world which I worshipped as divine."136

Camus offers a number of explanations for why the Greeks did not rebel metaphysically - a lack of a sense of the beyond in comparison to which the world's imperfection alone becomes apparent ${ }^{137}$; the absence of a teleological or linear conception of history and hence of the notion of a future that is free of the constraints of the past ${ }^{138}$; $a$ purely rational account of nature that placed limits on the experience of life and encouraged a kind of fatalism. ${ }^{139}$ Even though Camus offers these explanations as evidence of the superiority of the Greeks they tend to imply the opposite. They suggest a standard Christian progressivism in which the Greeks refused metaphysical rebellion not because they knew better but because their understanding of the world was insufficiently 
Ph.D. Thesis - R. Srigley McMaster - Religious Studies differentiated to permit that type of response. ${ }^{140}$ In other words the Greeks are inferior to both Christians and moderns because they belonged to an earlier and younger historical dispensation in which the full range of human experience had not yet become available.

Such slips back into the assumptions of The Rebel's Christian history are not uncommon for Camus. Fortunately they are not exhaustive of his analysis. There are moments when he abandons the hubris of the Christian metaphysic altogether and attempts to describe the Greeks on their own terms. When he does so his assessment of the relative maturity of their world vis-à-vis those of Christians and moderns is reversed. There is no comparable metaphysic here. Camus argues that the Christian desire for totality is not an index of human perfection but the consequence of a fear of death that has grown sufficiently disproportionate to create the types of existential imbalance we have witnessed in modernity. The real emotional and intellectual immaturity does not lie with the Greeks but with this fear of death and the apocalyptic desires its encourages. These are "adolescent furies" and childish obsessions in comparison to the lucidity, sobriety, and generosity of the Greeks. ${ }^{141}$ Rather than tame and educate our worst fears the Christian and modern teachings encourage them to increase without restraint. The price we have paid for this indulgence is not small. The debacle of modern totalitarianism, the wholesale slaughter of entire peoples that has continued unabated since that time, the empty consumer fetishism of Western culture and its lack of political insight and courage - these are only a few of the consequences. Rather than offer real hope the excessive self- 
Ph.D. Thesis - R. Srigley McMaster - Religious Studies interest and robust fear of death that these teachings provoked have created an almost impenetrable barrier to seeing the world as it is and have caused us to neglect the virtues necessary to live life sensitively and thoughtfully.

Several generations of deculturation have passed since Camus' time without any serious attempt being made to arrest the process. Camus had always hoped for a renaissance of Western culture, particularly in the post-war environment of France where the evidence of that deculturation was painfully apparent to everyone. By the time of the Algerian War Camus is notably less sanguine about such a possibility. The role of writers and intellectuals is to

clarify definitions in order to disintoxicate minds and to calm fanaticisms, even when this is against the current tendency. I have attempted this work of disintoxication as best I could. Let us admit that up to now the results have been nonexistent; these reports are also the record of a failure. ${ }^{142}$

Though his books remain resolute in their resistence to this cultural degradation they strike a more somber and cautious note regarding the possibility of change. No one listened, it seems. Three generations later the world continues as it did before. Who knows what horrors still await us if we continue to pursue our obsessions to their final term?

One of the primary aims of The Rebel was to overcome the fear of death that had encouraged modernity's apocalyptic aspirations and led to the extraordinary disfigurement of human and social relations that Camus describes in his analysis of 
Ph.D. Thesis - R. Srigley McMaster - Religious Studies

totalitarianism. ${ }^{143}$ This aim is stated explicitly in the book's epigraph, a passage from Hölderlin's poem The Death of Empedocles:

And I openly pledge my heart to the grave and suffering land, and often in the consecrated night, I promised to love her faithfully until death, unafraid, with her heavy burden of fatality, and never to despise a single one of her enigmas. Thus did I join myself to her with a mortal cord. ${ }^{144}$

What threatened to derail the analysis was precisely the apocalyptic aspirations and their promises of immortality that Camus had set out to overcome. These aspirations and hopes had established themselves as the sole locus of meaning in the West for over fifteen hundred years. So powerful were their influence that even critics tended to accept them as the paradigm of meaning. Imagining a type of meaning that did not bear their imprint was therefore an extraordinarily difficult undertaking. What further complicated the task was the fact that Camus was hard pressed to know what to offer in their place. Greek wisdom, certainly. But in relation to the desire for totality this appeared to be little more than an insistence on human partiality - a sound insight in its own right but pretty thin stuff in comparison to the extravagant promises of modernity. And Camus' acceptance of death seemed less an insight into the tragic character of life than a stoic resolve to accept harsh truths equitably. Again, a sound enough insight but perhaps not quite enough to get you to work in the morning.

The kinds of hesitations and contradictions apparent in Camus' histories were 
Ph.D. Thesis - R. Srigley McMaster - Religious Studies almost inevitable given the restrictions he placed on the cyclical books and the manner in which he carried out their respective analyses. Indeed the questions left unresolved in The Myth of Sisyphus tend to resurface in The Rebel in an amplified and more confusing way. Even though Camus argues in the former book that the absurd is not equivalent to the existentialist denial of nature or meaning, a measure of that denial still manages to creep into the analysis and in turn becomes, in part, the foundation on which The Rebel is constructed. It does not matter that Camus ultimately wanted to affirm the existence of a human nature. ${ }^{145}$ That affirmation was both necessary and laudable, particularly given the intellectual pressure of the period in which Camus worked. Yet by allowing the existentialist denial of nature to stand, even for heuristic or methodological reasons, Camus gave a measure of legitimacy to the very kinds of metaphysical rebellion The Rebel had been written to critique. What this meant practically is that another layer of modern confusions was added to the original one without either of them having been adequately clarified. ${ }^{146}$ The problem is not simply that Camus' manner of framing the argument meant he was not entitled to positions he clearly wanted to affirm. Logical problems like that are apparent in both The Myth of Sisyphus and The Rebel but they are not the most important ones. ${ }^{147}$ The most important problem in both books is that those modern (and Christian) confusions remained real and active parts of the analysis that continued to compete with and undermine Camus' best insights and to prevent him from achieving the ends he had set for himself in the cyclical books - namely, to explain and 
Ph.D. Thesis - R. Srigley McMaster - Religious Studies critically assess modernity. The following remarks summarize the nature of these problems in The Rebel.

In The Myth of Sisyphus there is a lingering doubt about the possibility of real moral insight or virtue in the absence of some sort of divine order. It is true that the absurd man does not reject God or the gods but only the Christian notion of an after life. It is also true that he considers the latter notion a hope at best and therefore irrelevant to such concerns. ${ }^{148}$ But that rejection frequently teeters toward a denial of all divinity and occasionally suggests the Christian teaching that without God the world is bereft of moral substance. ${ }^{149}$ This doubt about morality along with the suspicion that its origin lay in a denial of transcendent meaning reasserts itself in The Rebel. But in this book Camus seems to have switched sides in the debate, though again with doubts.

There are many plausible reasons for this change. Shortly after its publication Camus made it clear that he was uneasy with some of the more excessive formulations in The Myth of Sisyphus. ${ }^{150} \mathrm{He}$ even went so far as to append a number of shorter lyrical essays to later editions of the book in order to mitigate those excesses and to explain the experience he was concerned with in a broader context. ${ }^{151}$ We might also mention certain political and personal experiences. In the intervening years between The Myth of Sisyphus (1942) and The Rebel (1952) Camus witnessed the effective truth of National Socialism first hand and also learned about Stalin's Russia from writers like Arthur Koestler and Josef Czapski. ${ }^{152}$ The rejection of traditional morality and the utopian aspirations of these 
Ph.D. Thesis - R. Srigley McMaster - Religious Studies regimes led to a violence so unrestrained in its execution that it violated the principles of expediency even of the most realistic regimes. Was the wholesale sell-off of the wisdom of the ancient world and of Christianity that was underway in French cafés somehow complicit in this outcome? Camus worried over this question. ${ }^{153}$ He seems to have answered it affirmatively. His own "sense of the sacred"154 was by no means orthodox, but it afforded him something like the Christian distinction between transcendence and immanence as a means of explaining the moral vacuum and lack of restraint of modern regimes in their pursuit of totality. And there was at least some empirical evidence to support him. After all, was it not true that the death of God had been followed by the growth of totalitarianism and the perpetuation of some of the worst atrocities the world had witnessed? ${ }^{155}$ And was it not also true that so long as Christianity prevailed in the West those excesses and that lack of restraint were held in check?

These are the types of questions that preoccupied Camus while writing The Rebel. When he claims that "there is, in fact, no conciliation possible between a god who is totally separate from history and a history purged of all transcendence, ${ }^{, 156}$ he is affirming both poles of the tension as real and trying to find a way to bring them together. As we know, the way that he does so is not through the Christian mediator but through his own version - the rebel - who stands mid-way between "God and history."157 The problem is that even in this modified form all the assumptions of the original Christian account came rushing back into the analysis to destabilize it. The most problematic of these 
Ph.D. Thesis - R. Srigley McMaster - Religious Studies assumptions are those that underlie the Christian anthropology. According to that anthropology lack of restraint in human affairs is a direct consequence of our fallen nature. The fall initiated a change in human nature so complete that proper relationships to the world became impossible save for an act of divine grace. Effectively what this means is that there is no human nature in the Greek sense. Should the offer of divine grace be refused or denied, what remains is precisely the unrestrained motion of human desire that characterizes modernity and modern totalitarian regimes. The minute Camus' new mediator was challenged (which happened almost immediately) ${ }^{158}$ that lack of restraint and the apocalyptic ambitions it encouraged gained plausibility in the same way they had when the original Christian version of the account was first called into the question. Camus uses transcendence to quiet these ambitions and to defend us from the worst excesses of modern metaphysical rebellion. But because that transcendence was often just a stand in for the Christian God, the response amounted to letting the fox into the henhouse. The God who was to protect us from these excesses is the same one who encourages them. He does so by dedivinizing the world. This creates a vacuum in which the metaphysical rebel's ambitions can grow without the moderating influence of reality and its checks to human self-importance.

There is an image that occurs toward the conclusion of The Rebel that once again corrects these misunderstandings and confusions and also illuminates the way beyond them. As an antidote to the excesses of the age Camus offers Plato. ${ }^{159}$ 
Ph.D. Thesis - R. Srigley McMaster - Religious Studies

Plato is right and not Moses and Nietzsche. Dialogue on the level on mankind is less costly than the gospel preached by totalitarian regimes in the form of a monologue dictated from the top of a lonely mountain. ${ }^{160}$

Like Plato the true rebel pleads for life and for communication between human beings. No order need be imposed from above because the true order of life is always already there within us and around us. Religion and modernity distort that order and silence human beings by preventing "them from rediscovering themselves in the only value that can save them from nihilism - the long complicity of men at grips with their destiny."161 Camus continues his account of Plato by referring to the image of the cave in Book VII of the Republic. ${ }^{162}$

According to Camus' use of the image, Judaic, ${ }^{163}$ Christian, and modern attempts to impose order from above and the struggles for supremacy between them all properly belong to the shadow images of the cave. ${ }^{164}$ In Plato's account those who engage in this type of struggle "fight over shadows with one another and form factions for the sake of ruling, as though it were some great good." 165 And this is not all the image teaches us. For Camus those who believe that they "are capable of introducing unity into the world entirely on [their] own" act like "God himself." 166 So too for Plato. In the Republic the descent into the darkness of the cave is motivated by the human desire for mastery, perhaps even for a mastery that is absolute. Why? The notion that human beings control reality is difficult to sustain in the light of day because of the sheer overwhelming presence and magnitude of the world. But in the darkness of the cave where human 
Ph.D. Thesis - R. Srigley McMaster - Religious Studies beings sit entranced by the play of shadow images on the wall before them the illusion that reality can be controlled by us is much more easily sustained, perhaps even moreso for those who stage the performance than for those who watch it. This meaning is also consistent with Glaucon's character, for whom Socrates creates the image. The construction of Glaucon's city in speech (the Kallipolis) in books II through V of the Republic indicates his preference for top down, coercive forms of order to the kind of organic agreement between people - even between rulers and ruled - apparent in Socrates' account of human nature. ${ }^{167}$ Though the scope of Glaucon's ambition falls far short of those Camus describes in The Rebel, there is a family resemblance between them nonetheless.

The way to overcome the madness of these ambitions is the same for Camus as it is for Plato - one need simply leave the cave. Of course such an act is more easily described than performed. But despite whatever difficulties there may be in undertaking it, there is no reason in principle why it cannot be accomplished. And this points to another important insight in Camus' analysis. If Christian and modern attempts to impose order from above both take place within the darkness of the cave, then the findings of Camus' Christian history of modernity are overturned. Moderns are not the sole occupants of the cave. There are Christians down there too. And this means that what lies outside the cave is not God or the ideal in the Christian sense. It is simply the life of moderation or measure that Camus evokes at the conclusion of The Rebel through images 
Ph.D. Thesis - R. Srigley McMaster - Religious Studies of the Mediterranean. ${ }^{168}$ Not a perfect life, mind you. The Mediterranean sun also produces its own type of darkness. ${ }^{169}$ But it is a life free of the additional and unnecessary darkness of the cave. If I were to spell out these insights using an idiom I have employed throughout this work, I would say that transcendence and immanence in the Christian sense are both shadow images of the cave. Neither adequately reflects the true character of our moral experience; nor do they capture the nature of our occasional despair.

This insight too is not immune to the counter influence of Camus' Christian history. After explaining the problematic character of the Christian account Camus allows Christian assumptions to insinuate themselves back into the analysis nevertheless. No sooner does he offer Plato as an alternative to such assumptions than he equates his achievement with the Christian notion of mediation. ${ }^{170}$ And that allows the entire transcendence/immanence problematic to reassert itself and undermine his primary accomplishment. Whatever ground Camus gains in this work, he soon loses through the opposing tendencies of this argument.

In the final pages of The Rebel Camus tells us that rebellion "cannot exist without a strange form of love." ${ }^{\text {171 }}$ The same is true of a critique of rebellion, it would seem. For Camus love lies at the heart of the Greek world. No full or adequate account of human nature is possible without it. Nonetheless we will have to wait for Camus' next book The Fall - to learn about its most important implications for a critique of modernity. 
Ph.D. Thesis - R. Srigley McMaster - Religious Studies

\section{Notes}

1. Albert Camus, The Rebel, trans. Anthony Bower (New York: Vintage Books, 1991), $25,102$.

2. Ibid., $20,102$.

3. Ibid., $6,32$.

4. Ibid., 28, 303-4.

5. Ibid., $258,21$.

6. Ibid., 21-2.

7. Ibid., 16.

8. Ibid., 21.

9. Ibid., 21; Albert Camus, Essais (Paris: Gallimard, 1961), 431.

10. Ibid., 6,8 .

11. Ibid., 10.

12. Ibid., 102.

13. Ibid., 8.

14. Ibid., 247; Essais, 649.

15. Ibid., 247; Essais, 649.

16. Ibid., 7; Essais, 417.

17. Ibid., 23.

18. Ibid., 193; Essais, 598.

19. Ibid., 27-8, 102, 193, 244, 299, 306.

20. Ibid., 139, 6 . 
Ph.D. Thesis - R. Srigley McMaster - Religious Studies

21. Georges Bataille, "The Age of Revolt" in The Absence of Myth. Edited and translated by Michael Richardson (London: Verso, 1994), 167.

22. Ibid., 169.

23. Ibid., 170. Contrary to Bataille, Aristotle argues that the human being who is "preeminent in virtue [and] political capacity...should be regarded like a god among men; and from this it is also clear that laws should be framed only for those who are equal in birth and capacity, for no law exists for such a man-he is himself a law." Aristotle, Politics, (1284a, 5-15).

24. Ibid., 174.

25. Ibid., 100.

26. Ibid., 165.

27. Ibid., 170.

28. Ibid., 168-9.

29. Ibid., 171.

30. Ibid., 175.

31. Ibid., 173.

32. Ibid., 174.

33. Eric Voegelin, Anamnesis, trans. \& ed. Gerhart Niemeyer (Columbia: University of Missouri Press, 1978), 171.

34. Ibid., 305-6.

35. Ibid., 5, 170, 191.

36. Ibid., 172-3.

37. The formulation of this account that I discuss is taken from Eric Voegelin, The New Science of Politics (Chicago: The University of Chicago Press, 1952). Similar formulations can be found in subsequent essays such as "The Gospel and Culture" and 
$\mathrm{Ph} . D$. Thesis - R. Srigley McMaster - Religious Studies

"Immortality: Experience and Symbol," both of which are published in The Collected Works of Eric Voegelin, Volume 12, Published Essays, 1966-1985 (Baton Rouge: Louisiana State University Press, 1990), 172-212, 52-94.

38. In The New Science of Politics, the bulk of this analysis occurs in the chapter entitled "Gnosticism-The Nature of Modernity," 107-132. A lengthy study of the same phenomenon can be found in Voegelin's essay, "Wisdom and the Magic of the Extreme," in The Collected Works of Eric Voegelin, Volume 12, 315-375.

39. Eric Voegelin, The New Science of Politics, 122.

40. Eric Voegelin, The Collected Works of Eric Voegelin, Volume 12, 189.

41. Ibid., 191.

42. Ibid., 190.

43. Ibid., 190. The following passage from The New Science of Politics is typical of Voegelin's ambivalence about and conflicting understanding of the process of "dedivinization": "The evolution of mankind toward the rationality of positive science was for Comte a distinctly progressive development; for [Max] Weber it was a process of disenchantment (Entzauberung) and de-divinization (Entgöttlichung) of the world. By the overtones of his regret that divine enchantment had seeped out of the world, by his resignation to rationalism as a fate to be borne but not desired, by the occasional complaint that his soul was not attuned to the divine (religiös unmusikalisch), he rather betrayed his brotherhood in the sufferings of Nietzsche..." (22).

44. Ibid., 27. For a very clear exposition of this Christian claim see Søren Kierkegaard, The Sickness Unto Death, trans. Howard V. Hong \& Edna V. Hong, (Princeton: Princeton University Press, 1980), 87-100. See also Kierkegaard's Concluding Unscientific Postscript, trans. David F. Swenson \& Walter Lowrie (Princeton: Princeton University Press, 1941), 188-ff. There Kierkegaard argues that "Socratic ignorance is as a witty jest in comparison with the earnestness of facing the absurd [the incarnation]; and the Socratic existential inwardness is as Greek light-mindedness in comparison with the grave strenuosity of faith."

45. Ibid., 24, 57; Essais, 467.

46. Ibid., 19, 179, 304. See the "First Essay" of The Genealogy of Morals, trans. Walter Kaufmann \& R.J. Hollingdale (New York: Vintage Books, 1989). See also Friedrich 
Ph.D. Thesis - R. Srigley McMaster - Religious Studies

Nietzsche, The Antichrist, trans. R.J. Hollingdale (London: Penguin Books, 1990).

47. Friedrich Nietzsche, "On the Uses and Disadvantages of History for Life" in Untimely Meditations, trans. R.J. Hollingdale (Cambridge: Cambridge University Press, 1983), 72.

48. Ibid., 4.

49. Camus expresses this experience vividly in his lyrical essay, "Return to Tipasa," which was written a short time after the publication of The Rebel. Albert Camus, Lyrical and Critical Essays, trans. Ellen Conroy Kennedy (New York: Vintage Books, 1970), 162-171. See particularly pp. 164-5. The same type of experience is described by Solzhenitsyn in The Gulag Archipelago Two, part IV, "The Soul and Barbed Wire." Aleksandr I. Solzhenitsyn, The Gulag Archipelago Two, trans. Thomas P. Whitney (New York: Harper and Row, Publishers, 1975), 595-672.

50. Ibid., 250. In Resistance, Rebellion, and Death Camus explains his resistance to his time in this way: "I know that the great tragedies of history often fascinate men with approaching horror. Paralyzed, they cannot make up their minds to do anything but wait. So they wait, and one day the Gorgon devours them. But I should like to convince you that the spell can be broken, that there is only an illusion of impotence, that strength of heart, intelligence, and courage are enough to stop fate and sometimes reverse it." Albert Camus, Resistance, Rebellion, and Death, trans. Justin O'Brien (New York: Vintage Books, 1974), 141.

51. Albert Camus, The Rebel, 288; Essais, 692.

52. Ibid., 102; Essais, 510.

53. Ibid., 26.

54. Ibid., 32.

55. Ibid., 33.

56. Ibid., 32.

57. Ibid., 190, 299, 32.

58. Ibid., 32; Essais, 443-444. 
Ph.D. Thesis - R. Srigley McMaster - Religious Studies

59. Camus repeats more or less the dialectical form of the Christian account in the following lines: "The night on Golgotha is so important in the history of man only because, in its shadow, the divinity abandoned its traditional privileges and drank to the last drop, despair included, the agony of death. This is the explanation of the Lama Sabactani and the heart-rending doubt of Christ in agony. The agony would have been mild if it had been alleviated by hopes of eternity. For God to be a man, he must despair." Ibid., 33.

60. Ibid., 33-34. Martin Buber was very favourably impressed by The Rebel. However, in a letter to Camus regarding its publication in Hebrew, he objected to Camus' interpretation of Judaism on precisely this point. "There is only one phrase in the book that I find unjust, but it does bother me exceptionally. It is on page 370 where you speak of the 'ciel implacable' of the Old Testament. That is absolutely incorrect. The divine words 'I dwell on high, in holiness; yet with the contrite and lowly in spirit' (Isaiah 57:15) are not an exception; they are the very substance of this world." In other words, dedivinization is not a Jewish problem, at least not in the sense that it is in Christianity. Camus' response was conciliatory: "I readily admit that the sentence that gave you pause deserves numerous nuances, and I would have no objection to its being modified. That is the drawback of enterprises that presume to sum up what cannot be summed up. But my main effort was directed at the basic idea, even at the risk of obscurities and injustices. At any rate, I shall gratefully accept any critique that points these injustices out to me and permits me to rectify them." Martin Buber, The Letters of Martin Buber, eds. Nahum N. Glatzer and Paul Mendes-Flohr, trans. Richard and Clara Winston and Harry Zohn (New York: Schocken Books, 1991), 568-7.

61. Albert Camus, The Rebel, 35.

62. Ibid., 147.

63. Ibid., 115, 198, 241, 248.

64. Ibid., 262, 302.

65. Ibid., 190, 110.

66. Ibid., 100-101, 250, 291.

67. Ibid., 288, 290. 
Ph.D. Thesis - R. Srigley McMaster - Religious Studies

68. Ibid., 267, 262. These extreme formulations occur in Camus' discussion of the nature of art. What is odd about this is that it is precisely when Camus is practicing his art, namely, when he is writing novels and short stories, that this very modern ambition is least apparent in his work. In any event, contrast what Camus here says about the nature of art with the much more realistic and unsentimental account offered by Iris Murdoch: "[Literature and painting] show us the absolute pointlessness of virtue while exhibiting its supreme importance; the enjoyment of art is training in the love of virtue... This form often seems mysterious to us because it resists the easy patterns of the fantasy, whereas there is nothing mysterious about the forms of bad art since they are the recognizable and familiar rat-runs of selfish day-dream. Good art shows us how difficult it is to be objective by showing us how differently the world looks to an objective vision." Iris Murdoch, The Sovereignty of the Good (London: Routledge \& Kegan Paul, 1970), 86.

69. Two remarks will serve as examples: "The only thing that gives meaning to human protest is the idea of a personal god who has created, and is therefore responsible for, everything." "The enormous number of sects among the second-generation Gnostics indicates how desperate and diversified was the attempt on the part of Greek thought to make the Christian universe more accessible and to remove the motives for a rebellion that Hellenism considered the worst of all evils." Albert Camus, The Rebel, 28, 33.

70. Ibid., 190, 212, 192-3, 222, 242.

71. Ibid., 190.

72. Ibid., 299.

73. Ibid., 192.

74. Ibid., 192-193.

75. Ibid., 193.; Essais, 597.

76. Ibid., 193.

77. Ibid., 190, 299.

78. Ibid., 190; Essais, 594.

79. Ibid., 189; Essais, 594.

80. Ibid., 190. 
Ph.D. Thesis - R. Srigley McMaster - Religious Studies

81. The passage Camus refers to here as evidence of this view is taken from Aristotle's Problems, 17, 3: "If, then, there is a circle, and a circle has neither beginning nor end, men would not be 'before' because they are nearer the beginning, nor should we be 'before' them, nor they 'before' us." Aristotle, Problems, Vol. 1, The Loeb Classical Library, ed. T. E. Page, trans. W. S. Hett (Cambridge: Harvard University Press, 1936), 367. Camus first refers to this passage in his M.A. thesis, Christian Metaphysics and Neoplatonism, trans. Ronald Srigley (Columbia: University of Missouri Press, 2007), 41. The statement is conditional and speculative at best, and does not appear to be a doctrine about the nature of history or about whether the cosmos is eternal or created.

82. Albert Camus, The Rebel, 189.

83. Ibid., 190.

84. Voegelin, The New Science of Politics, 107

85. Ibid., 109.

86. Ibid., 119-20. Voegelin's standard argument is that modern revolutionary accounts are essentially Christian heresies in which true "Christian transcendental fulfillment becomes immanentized."

87. Albert Camus, The Rebel, 28; Essais, 439.

88. Camus describes the ancient Greek account as a type of pantheism, which he distinguishes from both the "vertical" transcendence of Christianity and the modern notion, most clearly expressed in Hegel, of an immanent unfolding of the spirit in "the evolution of the world." Ibid., 142. One of the most common ways that Camus himself expresses the meaning of this pantheism is by associating it with our experience of "beauty," which he claims "carries the promise" of "a living transcendence." Ibid., 276, 258. In terms of its content, Camus claims that the experience of beauty increases our attachment to this "mortal world" while at the same time moving us to overcome or transcend its worst "injustices" or evils. Ibid., 276. As such it is perhaps a better, more fitting way to describe our experience of the divinity that pervades all things. Cf. also Camus' essays "Helen's Exile" and "The Desert" in Lyrical and Critical Essays, 93-105; 148-153.

89. This is more or less Nietzsche's assessment of modernity in Twilight of the Idols, "How the 'Real World' at last Became a Myth." If there is no "other world" then there is no "this world" either. The problem is a false one. Or as Nietzsche puts it: "We have 
Ph.D. Thesis - R. Srigley McMaster - Religious Studies

abolished the real world: what world is left? the apparent world perhaps? ... But no! with the real world we have also abolished the apparent world!" Friedrich Nietzsche, Twilight of the Idols/The Anti-Christ, trans. R. J. Hollingdale (London: Penguin Books, 1990), 50-1.

90. At the end of his discussion of historical rebellion Camus describes this phenomenon by means of the myth of Prometheus. "Prometheus, in his turn, becomes a master who first teaches and then commands. Men doubt that they can safely attack the city of light and are even uncertain whether the city exists. They must be saved from themselves. The hero tells them that he, and he alone, knows the city. Those who doubt his word will be thrown into the desert, chained to a rock, offered to the vultures. The others will march henceforth in darkness, behind the pensive and solitary master. Prometheus alone has become god and reigns over the solitude of men." Albert Camus, The Rebel, 245. Camus makes it clear that this new, modern Prometheus is not the "real, the eternal Prometheus." Ibid. Yet the use of the myth in this context is still strange, because in his earlier discussion of Prometheus, Camus claims that such ambitions are entirely foreign to the myth's teaching. They are not, however, foreign to the ambitions of Christianity as Camus describes it in the preceding discussion. Indeed, here Prometheus appears to be not Greek at all, but a slightly more aggressive Christ, similar to the one we encounter in John's apocalypse.

91. Ibid., 224, 243, 239.

92. In his essay "The Dark Night Before the Coming of Grace" Bernard Murchland writes that "the development of [Camus'] work must, if it continues, ultimately culminate in some spiritual position." In Camus: A Collection of Critical Essays, ed. Germaine Brée (New Jersey: Prentice Hall, 1962), 63.

93. The differences in tactics between Bakunin and Nechaiev is one way of illustrating this opposition. See Albert Camus, The Rebel, 162-3.

94. Though Camus argues that both are deeply implicated in the excessive violence of the revolution, he makes a clear distinction between them in terms of the nature of their motives and the quality of their character. "Do not let us confuse, even for a moment, the imposing figure of Saint-Just with the sad spectacle of Marat - Rousseau's monkey, as Michelet rightly calls him. But the drama of Saint-Just lies in having at moments joined forces, for superior and much deeper reasons, with Marat." Ibid., 127.

95. "If Nietzsche and Hegel serve as alibis to the masters of Dachau and Karaganda, that does not condemn their entire philosophy. But it does lead to the suspicion that one aspect 
Ph.D. Thesis - R. Srigley McMaster - Religious Studies

of their thought, or of their logic, can lead to these appalling conclusions." Ibid., 137.

96. Ibid., 21.

97. Ibid., 115.

98. Ibid., 116.

99. Ibid.

100. Ibid., 120.

101. That is to say, "Truth" and "Justice." Ibid., 122.

102. Ibid., 122.

103. Ibid., 123.

104. "Every form of moral corruption is at the same time political corruption, and vice versa. A principle of infinite repression, derived from this very doctrine, is then established." Ibid., 123.

105. Ibid., 132.

106. Ibid.

107. Ibid., 142.

108. "From the moment that eternal principles are put in doubt simultaneously with formal virtue, and when every value is discredited, reason will start to act without reference to anything but its own successes." Ibid.

109. Ibid., 146.

110. For a clear statement of this reasoning, see Jean-Paul Sartre, Existentialism and Humanism, trans. Philip Mairet (London: Methuen \& Co. Ltd., 1948), 26-28.

111. Albert Camus, The Rebel, 147.

112. Albert Camus, Essais, 488.

113. Albert Camus, The Rebel, 228. 
Ph.D. Thesis - R. Srigley McMaster - Religious Studies

114. Ibid., 223-224.

115. Ibid., 223.

116. Ibid., 212.

117. The Revelation of St. John the Divine, Authorised Version. See particularly chapters 18-22.

118. Albert Camus, The Rebel, 250.

119. "Is it possible to find a rule of conduct outside the realm of religion and its absolute values?" Ibid., 21. A series of similar questions and formulations are apparent in Camus' analysis of Ivan Karamazov' rebellion. See Ibid., 55-51.

120. The construction of existence and the achievement of a total meaning through historical action. Ibid., 250.

121. "Our revolution is an attempt to conquer a new existence, by action that recognizes no moral strictures." Ibid.

122. "The destruction of man once more affirms man. Terror and concentration camps are the drastic means used by man to escape solitude. The thirst for unity must be assuaged, even in the common grave. If men kill one another, it is because they reject mortality and desire immortality for all men. Therefore, in a sense, they commit suicide. But they prove, at the same time, that they cannot dispense with mankind; they satisfy a terrible hunger for fraternity." Ibid., 247-248.

123. See Eric Voegelin, "Configurations of History in The Collected Works of Eric Voegelin, Vol. 12, Published Essays 1966-1985 (Baton Rouge: Louisiana State University Press, 1990), 106-107.

124. Ibid., 188-245.

125. Ibid., 233.

126. Ibid., 240.

127. Ibid., 193.

128. Ibid., 189. 
Ph.D. Thesis - R. Srigley McMaster - Religious Studies

129. Ibid.

130. Ibid., 190.

131. See Albert Camus, "On the Future of Tragedy" in Lyrical and Critical Essays, 295310.

132. Ibid., 305-306. See also "Return to Tipasa" in Lyrical and Critical Essays, 171.

133. Albert Camus, Essais, 597.

134. Albert Camus, Notebooks 1942-1951, 128. The might also be a trace of this notion in Augustine's claim that "though the higher things are better than the lower, the sum of all creation is better than the higher things alone." Saint Augustine, Confessions, trans. R. S. Pine-Coffin (London: Penguin Classics, 1961), Book VII, 13.

135. Albert Camus, The Rebel, 27.

136. Albert Camus, Lyrical and Critical Essays, 7.

137. Albert Camus, The Rebel, 27, 28.

138. Ibid., 189-190.

139. Ibid., 27.

140. A similar argument has been made by Eric Voegelin. See his essay "Reason: The Classic Experience" in Anamnesis, trans. Gerhardt Niemeyer (Columbia: University of Missouri Press, 1978), 89-115. For a very different account, one more consistent with Camus' argument, see Paul Feyerabend, Conquest of Abundance: A Tale of Abstraction Versus the Richness of Being, ed. Bert Terpstra (Chicago: The University of Chicago Press, 1999), 216.

141. "We shall choose Ithaca, the faithful land, frugal and audacious thought, lucid action, and the generosity of the man who understands." Albert Camus, The Rebel, 306.

142. The role of intellectuals is to "clarify definitions in order to disintoxicate minds and to calm fanaticisms, even when this is against the current tendency. I have attempted this work of disintoxication as best I could. Let us admit that up to now the results have been nonexistent; these reports are also the record of a failure." Albert Camus, "Preface to Algerian Reports" in Resistance, Rebellion, and Death, 121. 
Ph.D. Thesis - R. Srigley McMaster - Religious Studies

143. Albert Camus, The Rebel, 233-245. Though this is an interpretation that would have to be worked out in detail, I think that Camus' analysis in these pages draws heavily on Orwell's book Nineteen Eighty-Four, which had been published in French by Gallimard just two years earlier, in 1950.

144. Ibid., 2.

145. "Analysis of rebellion leads at least to the suspicion that, contrary to the postulates of contemporary thought, a human nature does exist, as the Greeks believed." Ibid.,16.

146. By adequately I mean consistently. The analyses of both The Myth of Sisyphus and The Rebel remain admirable in many ways.

147. The strange and repetitive arguments about the absurd at the outset of The Rebel are good examples of these types of logical problems. Camus was obviously and hopelessly attempting to make rebellion appear to be the logical outcome of the absurdist denial of meaning. Albert Camus, The Rebel, 5-11.

148. Albert Camus, The Myth of Sisyphus, 102.

149. "I leave Sisyphus at the foot of the mountain! One always finds one's burden again. But Sisyphus teaches the higher fidelity that negates the gods and raises rocks." Ibid., 111. As for the suggested denial of transcendence, consider the following remark: "Thus, convinced of the wholly human origin of all that is human, a blind man eager to see who knows that the night has no end, he is still on the go." Ibid., 110.

150. On of the clearest signs of that uneasiness is his addition of the preliminary note entitled "An Absurd Reasoning." This note does not appear in the earliest versions of the text. Albert Camus, Essais, 1430, P 97, n1.

151. The broader context missing from the analysis itself, due to the methodological assumptions on which it rested?

152. Ronald Aronson, Camus and Sartre: The Story of a Friendship and the Quarrel that Ended It, 84-89. Oliver Todd, Albert Camus: A Life, 314.

153. Albert Camus, Notebooks 1942-1951, 146, 159; Albert Camus, "Return to Tipasa" in Lyrical and Critical Essays, 170-171.

154. Albert Camus, "Replies to Jean-Claude Brisville" in Ibid., 364. 
Ph.D. Thesis - R. Srigley McMaster - Religious Studies

155. Harvey Mansfield writes in this regard that "the uncompromising reason with which we have destroyed divine authority is accompanied by the untrammeled will that has destroyed self-government and been guilty of genocide. Can it be an accident that the first atheist regimes in human history were the first totalitarian regimes?" Harvey C. Mansfield, Manliness (New Haven: Yale University Press, 2006), 237.

156. Albert Camus, The Rebel, 288.

157. Ibid., 290.

158. Sartre makes this criticism in his "Réponse à Albert Camus," and he was certainly right to do so.

159. For an interesting discussion of Camus' use of Plato, particularly his image of the cave, see Karl Modler, Soleil et Mesure dans L'euvre d'Albert Camus, (Paris: L'Hamattan, 2000). Against Paul Archambault, Modler argues that Plato was an important and abiding source for Camus. He also argues that although Camus changes Plato's image in a variety of ways, his meaning remains consistent with Plato's and serves the additional function of freeing him from the limitations of a Christian interpretation of the cave. The following passage from Modler's book illustrates both arguments: "Le renvoi à Platon est évident: les notions de caverne, de mur, d'ombre, de soleil, la tripartition par le double 'plus haut', l'idée d'emprisonnement, tout cela en témoigne. Les transformations les plus significatives par rapport au text de Platon concernent l'absence d'un feu ainsi que le sujet narratif qui se retrouve seul dans la caverne sans être entraîné à l'extérieur. Ces changements expriment une réserve du jeunne Camus à l'égard d'une interprétation chrétienne du platonisme"(135).

160. Albert Camus, The Rebel, 284.

161. Ibid.

162. Plato, Republic, 514a-521c.

163. See note 60 above.

164. According to "The Enigma," this is also the status of most French intellectual life. Albert Camus, "The Enigma" in Lyrical and Critical Essays, 161.

165. Plato, Republic, 520cd.

166. Albert Camus, The Rebel, 285. 
Ph.D. Thesis - R. Srigley McMaster - Religious Studies

167. Consider the genesis of the guardians in book III. "When they've come, let them look out for the fairest place in the city for a military camp, from which they could most control those within, if anyone were not willing to obey the laws, and ward off those from without, if an enemy, like a wolf, should attack the flock." Plato, Republic, 415de.

Glaucon agrees heartily with the description, even though it violates what he has already agree to regarding the relationship between rulers and rules in Socrates' account of moderation (430d-432b). Consider also Socrates' repeated efforts to encourage Glaucon not to be so hard on the many. Ibid., $414 \mathrm{e}, 499 \mathrm{~d}$.

168. Ibid., 300-306. For an interesting analysis of these images, see Karl Modler, Soleil et mesure dan l'cuvre d'Albert Camus.

169. "We are well aware, aren't we, if we come from the South, that the sun has its black side?" Albert Camus, "Encounter with Albert Camus" in Lyrical and Critical Essays, 357. This is also consistent with Plato's image of the cave, in which darkness is also present outside the cave. There is night, and there are shadows. Plato, Republic, 516a.

170. "These tendencies [i.e., historical conquest] - and not the concepts of mediation, which would have comprised the real strength of Christianity - are triumphing in modern times, to the detriment of Christianity itself, by an inevitable turn of events." Albert Camus, The Rebel, 299.

171. Ibid., 304. 
Ph.D. Thesis - R. Srigley McMaster - Religious Studies

\section{PART TWO: TWO WORKS OF FICTION}

\section{Introduction}

The limitations and inadequacies of The Myth of Sisyphus and The Rebel encouraged Camus to rethink the methodology of the cyclical books and to reorient his critical analysis of modernity in the years following the latter's publication. There is evidence of both efforts in his shorter prose writing from the period and in the content and new literary character of the stories that make up Exile and the Kingdom. ${ }^{1}$ In part what distinguishes these works is that they are more awkward and uncertain than those that preceded them. Camus' rethinking of things is apparent in their searching character; he is like a man groping his way in the dark toward something he apprehends but does not yet fully understand. But they are also far clearer and less conciliatory about the Christian and modern sensibilities that had given Camus so much trouble in The Myth of Sisyphus and The Rebel. Stories like "The Renegade" and "The Growing Stone" are unapologetic critiques of modern apocalyptic ambitions and Christian claims to exclusivity. ${ }^{2}$ And in works like "The Artist at Work" and "Return to Tipasa" Camus demonstrates that he is much more aware and self-critical of his own confusions about these ambitions and claims than he had been previously. ${ }^{3}$

Camus' rethinking of his critique of modernity achieved its most mature expression in The Fall. This book was originally intended to be included in Exile and the Kingdom but in the writing of it Camus realized that it was a work unto itself. ${ }^{4}$ As the 
Ph.D. Thesis - R. Srigley McMaster - Religious Studies epigraph from Lermontov indicates, the book is "a portrait, but not of an individual; it is the aggregate of vices of our whole generation in their fullest expression." $"$ The Myth of Sisyphus and The Rebel are portraits too - of the absurd man and the rebel respectively. But these are only partial images of modernity and do not penetrate to its most fundamental character or motivation. In The Fall Camus completes the portrait. He does so by ceasing to take modernity at its own word and instead by formulating the critical analysis in terms that its defenders would not accept but that better bring to light modernity's true character. The key term here is love, called for at the conclusion of The Rebel and constantly evoked in Camus' earliest books and in his best fiction as the truest or highest expression of what life is. ${ }^{6}$ In The Fall there is no complete or positive account of this experience. The book explores modernity as a manifestation of love, it is true. But it is a pathological form of love. In chapter three I offer a close reading of The Fall that attempts to indicate the substance of Camus' critique of modernity and to explain its relationship to the Christian teachings about the fall and redemption. I argue that here finally Camus becomes clear about these things and finds his way beyond them.

Camus' positive account of the nature of love was to be the subject of his third cycle of books, drawn together under theme of Nemesis. These books were never completed due to his death in 1960. All we have of them is a draft of the first part of the posthumously published novel The First Man. Though this is not much to go on I think it provides us with sufficient insight to allow us to speak meaningfully albeit tentatively 
Ph.D. Thesis - R. Srigley McMaster - Religious Studies about Camus' mature understanding of love and the manner in which this last cycle of books would have departed from the previous two. In The First Man Camus creates a clearing in which to talk about life as he experiences it, without the distorting influences of either Christian or modern sensibilities. Of course these sensibilities have to be explained nonetheless because they too are part of the contemporary world. But my guess is that Camus would have done so by exploring them as secondary phenomena to be accounted for in terms of a broader range of erotic responses to life that make up and better express the true character of the world. At any rate, in terms of the religious iconography that Camus uses in this book as well as in those that preceded it, I argue that The First Man is his attempt to create an image of life before the fall, that is to say, before the advent and influence of the Christian historiography and its modern successors. Not a perfect life, mind you. Camus rejects that aspect of the Christian teaching too. Simply life as we all experience it, with its full range of hope and despair, its sufferings and its triumphs, only understood without the excessive and immoderate interpretations of these things to which we have become accustomed in modernity. These are the aspects of The First Man that I will examine in chapter four of this work. 
Ph.D. Thesis - R. Srigley McMaster - Religious Studies Notes

1. The shorter prose pieces I have in mind are essays like "Return to Tipasa" and "The Sea Close By" and the political essays on Algeria gathered together in Resistance, Rebellion, and Death.

2. Albert Camus, Exile and the Kingdom, trans. Justin O'Brien (New York: Vintage International, 1991), 34-61; 159-213.

3. Ibid., 110-158. Albert Camus, Lyrical and Critical Essays, 162-171.

4. Albert Camus, "Excerpts from Three Interviews" in Ibid., 320.

5. Albert Camus, The Fall.

6. Albert Camus, The Rebel, 304; Nuptials in Lyrical and Critical Essays, 102; The Plague, 213. 
Ph.D. Thesis - R. Srigley McMaster - Religious Studies

Chapter Three: Modernity in its Fullest Expression

Christianity gave eros poison to drink: he did not die of it but degenerated - into a vice.

Friedrich Nietzsche, Beyond Good and Evil

Most commentators agree that The Fall departs from Camus' previous fiction in important ways. It is more complex and challenging psychologically; and its content is darker and less forgiving than anything Camus had written previously. But there are disagreements about how that difference should be interpreted. My interpretation of The Fall is less conventional than most. Though I agree with the common opinion that it marks a break with the earlier books, my account of that break differs considerably.

After the publication of The Rebel Camus realized that there was something about his account of modernity that encouraged misinterpretations like Sartre's and made them seem plausible. This was a substantial problem for Camus, not a political one. He had already won the fight with Sartre on the level of principle, but he understood in some measure that there was something in his writings that justified Sartre's criticism nonetheless. ${ }^{1}$

I think the problem with Camus' critique is threefold. Its first aspect is methodological. The critique rested on the assumption that modernity's excesses could be traced back to earlier, more moderate modern aspirations, and thus that an alternative to those excesses could be found through an exploration of their historical origins. ${ }^{2}$ The difficulty was that although these origins were empirically more moderate than their 
Ph.D. Thesis - R. Srigley McMaster - Religious Studies successors, it was not because they differed from them substantially, but because either sufficient time had not elapsed for their full consequences to be realized or the lingering influence of other, non-modern factors that had not yet been silenced entirely kept them in check. The effective truth of this method was that each time Camus arrived, whether historically or analytically, at one of these allegedly pure origins, he did so only to discover that he had not escaped modernity at all but merely found its expression in an earlier dispensation. And that only reintroduced into the analysis the very excesses he initially set out to analyze critically and to overcome.

The second aspect of the problem is related to the first. The place where Camus always pulled up short or hesitated in his histories and even in his fiction to some extent was Christianity. The critique of modernity consistently lead him back to Christianity as its real historical and existential source. ${ }^{3}$ But for some reason Camus was reluctant to state the critique unequivocally. ${ }^{4}$ This was not without consequences, the most important of which was that Christian apocalyptic aspirations and the metaphysical unrest out of which they grew continued to appear in Camus' writings as a true expression of the human desire for salvation. And once the formulation was accepted, how could Camus deny truth and legitimacy to modern expressions of the same desires and experiences? ${ }^{5}$ The short answer is that he could not, and this is why the apocalyptic ambitions of metaphysical rebellion continued to make their way back into the analysis and to undermine even the most compelling features his critical analysis. 
Ph.D. Thesis - R. Srigley McMaster - Religious Studies

The third aspect of the problem is the most important. It concerns an omission from Camus' analysis. The methodological restrictions I have discussed above required him to accept, however provisionally, the presuppositions of modernity as the starting point of his essays. These presuppositions effectively hamstrung the analysis because they did not allow Camus to explore experiences that went beyond the limits they prescribed. The following remark from The Rebel is typical in this regard. "The first and only evidence that is supplied me, within the terms of the absurdist experience, is rebellion. Deprived of all knowledge, incited to murder or to consent to murder, all $\mathrm{I}$ have at my disposal is this single piece of evidence, which is only reaffirmed by the anguish I suffer." The difficulty here is not merely the restriction of the analysis to a certain range of experience - the absurd, rebellion; it is the restriction of the analysis to modern interpretations of those experiences. Everyone thinks the world is absurd at some point or another; and there are likely very few people if any who believe that rebellion is not a legitimate response to unfair or unjust circumstances. But not everyone, and probably not even most people, experience the absurd or rebellion in the way that Camus describes them in The Myth of Sisyphus and The Rebel. And no one analyzing these experiences, even in the modern context, is obliged to accept an interpretation of them that prevents him from considering whatever experience he deems necessary for a proper treatment of the subject.

The oddness of this procedure becomes even more pronounced when we realize 
Ph.D. Thesis - R. Srigley McMaster - Religious Studies

that it was likely intentional. ${ }^{7}$ The plan of the cyclical books from a very early date was to work up the analysis of modernity by exploring it on its own terms and without bringing into the analysis anything it did not accept. The approach is clearly described in an essay Camus wrote for Combat in 1945: "No, everything is not summed up in negation and absurdity. We know this. But we must first posit negation and absurdity because they are what our generation has encountered and what we must take into account." ${ }^{\prime 8}$ The intention is admirable but the method ultimately proved unworkable. The absurd and rebellion, even when freed from their modern interpretations, did not allow Camus to get to the heart of the modern project because they excluded analytically the experience of love. That experience was foundational for Camus. In a number of lyrical works not belonging to the cyclical structure of books at all Camus makes it clear that love is somehow the very essence of human life. ${ }^{9}$ But for some reason he believed that real participation in and analysis of the modern world required that he set aside his best insight, albeit temporarily. The method finally ground to a halt after the publication of The Rebel, which was followed by a long period of silence and indecision. Then Camus began to speak of the need to return to the "ancient path" he first explored in those early lyrical works, The Wrong Side and the Right Side and Nupitals, and to devote himself to the exploration of a "certain form of love."

The Fall is an intermediate stage between the cycles of rebellion and love. Here Camus stopped hesitating. First he cleared up the methodological problem by abandoning 
Ph.D. Thesis - R. Srigley McMaster - Religious Studies its main assumption: that the critique of modernity could be teased out of the presuppositions of modernity itself. No more concessions to modernity's good intentions; and no more conciliation in relation to Christianity either. Though it is true that Camus uses Christian symbols frequently in The Fall, and that his references to Jesus are sympathetic, ${ }^{10}$ his analysis of Christianity itself is anything but sympathetic. A careful reading of the text makes it clear that Camus finally completes his critique of the modern project by extending the critical analysis to the very foundations of its apocalyptic aspirations: namely, to the metaphysical unrest that is Christianity's central teaching. But most important, he explores this unrest and its apocalyptic expressions as manifestations of a self-love that had become deadly because it had been loosed from all forms of restraint. $^{11}$

The success of the critical analysis does not mean that The Fall offers a positive account to replace those it rejects. Its intermediate status is real. The analysis remains largely negative. It offers an image the ugliness of modernity without much to compensate for or correct it. But there are hints of such an account nonetheless. Several of The Fall's key images and its argument regarding nature of Clamence's pathology point to the Greeks as an alternative to modernity's madness. They have not been corrupted by the latter's influence and are a good bet for restoring at least some measure of existential health. 
Ph.D. Thesis - R. Srigley McMaster - Religious Studies

This is not the way The Fall is usually read. Many commentators point to the similarities between Camus' life and Clamence's as evidence in support of an autobiographical interpretation of the book. This type of reading was encouraged by Sartre and de Beauvoir. ${ }^{12}$ In the quarrel that followed the publication of The Rebel both did what they could to make Camus' personal failings a subject of public debate. That influence was so great that even commentators who tended to side with Camus often accepted the autobiographical assumption, though they understood its purpose differently. Tony Judt agrees that The Fall is confessional but argues that in offering it Camus was being more than a little disingenuous. His real aim was not confession but revenge. By describing graphically his own moral failures he would turn the tables on Sartre and de Beauvoir and beat them at their own game. "Camus used the novel to invert the procedure of which he had been a victim in Les Mandarins, where Simone de Beauvoir transposed all Sartre's worst characteristics and acts onto the Camus figure in her roman à clef; Camus took his own failings as he saw them, generalized them across the spectrum of Parisian intellectual life, and then subjected them to cruel inspection and interrogation in the manner of his own intellectual enemies." ${ }^{\text {"13 }}$ According to the reading, in The Fall Camus finally comes clean, as he promised he would. He no longer wished to keep up the pretense of being an austere moralist that earlier works had encouraged. Only in setting the record straight Camus was not going to go down alone. He would take Sartre, de Beauvoir, and the French intellectual establishment with him. Thus does Camus become 
Ph.D. Thesis - R. Srigley McMaster - Religious Studies his own character, the question of whether that is a good thing or a bad one being left to the individual reader's taste. ${ }^{14}$

Jean Onimus acknowledges certain similarities between Camus and Clamence but does not interpret them as does Judt. Onimus reads The Fall as a critique of the modern project about which Camus was absolutely serious. He considers the critique all the more successful because it is offered by Camus, who had participated fully in that project and who had pushed it to its furthest point. According to Onimus this is the manner in which The Fall departs from Camus' earlier books. It is an indictment of the very modernity he had previously championed and defended.

Onimus claims that The Fall is something like a propaeduetic to Christian faith. Camus acknowledges openly the futility of the modern project to which he had previously devoted himself. Broadly speaking the aim of that project was to make human beings happy and fulfilled without the help of divine revelation, which moderns deny in favour of their own efforts to achieve a kind of self-salvation. It rested on the assumption of the possibility of human progress to the point where the nagging imperfections inherent in all human action would no longer bar the way to genuine improvement. In The Fall, Onimus argues, that assumption finally collapsed for Camus. His earlier optimism regarding the human condition came apart after encountering the bedrock of human sin. As Onimus writes of Clamence, "but there took effect in Clamence a strange work of demystification that acted against his own happiness, revealing its illusoriness, the fraud."15 According to 
Ph.D. Thesis - R. Srigley McMaster - Religious Studies

Onimus, in The Fall this demystification broadens out into a general insight into human nature:

A character of this kind goes far beyond being a satire of the contemporary scene. Clamence bears witness to a sickness that is in the conscience, that is to say, in what is most noble and pure in man. Man is then irremediably wedded to his duplicity and without any hope of salvation. We are quite far from the arrogant humanism of Kirillov [which Camus previously had endorsed]. ${ }^{16}$

The modern project is unrealizable because it ignores this basic characteristic of our fallen human nature.

Despite how disturbing this discovery of human duplicity and evil may have been for Clamence and Camus, Onimus claims that it is an advance nonetheless. The one who knows he is damned is better off than the one who is damned but believes himself to be saved. This, too, is a central Christian teaching and an essential element of Christianity's appeal. Coming finally to recognize the impossibility of the human condition is a necessary prelude to the possibility of salvation. It also offers an explanation of and some comfort for the apparent futility of human action. "From a religious point of view, the most Dostoevskian of Camus's [sic] heroes is also the most ambiguous. Did not Bishop Tihon tell Stavrogin that the sinner aware of his evil is at the last rung of the ladder, the one that precedes prayer and pardon?"17 Clamence and Camus both stop short of the Christian solution, of course. Their condition therefore remains insuperable from a human standpoint, and Clamence's "judge-penitent is a poor palliative." 18 It is in any case no match for the depths of the problem that Camus has discovered. The brutal violence of 
Ph.D. Thesis - R. Srigley McMaster - Religious Studies Clamence's response to his condition and the extent of the deception and self-deception required to sustain it testify to a profound self-hatred that is the inescapable condition of the unredeemed or natural human being. As Onimus says following Georges Bernanos, that self-hatred "is at the utmost depth...probably of every life" " and is unpardonable. ${ }^{19}$ The only way out and the only possible healing comes through God. "In order to become reconciled with himself" Bernanos had recourse to "that supernatural knowledge of oneself - of oneself in God - that is called faith'."20

The narrative is so familiar to us that we barely raise an eyebrow when we hear it, even when it is applied to a writer like Camus. Nonetheless there are a number of important interpretive problems, the first of which is Camus' own commentary on the book. An author's interpretation is not necessarily the final word on a book's meaning, but it should at least serve as guide, particularly when it is corroborated by the book's content. In an interview in 1956 Camus was asked whether The Fall signaled, as some had suggested, a "rallying to the spirit if not the dogma of the Church." His reply was unequivocal: "Nothing really justifies them in this." ${ }^{21}$ But there are other, more important textual problems with Onimus' interpretation.

The first of these is Onimus' assessment of Clamence's pre-fall condition. He claims that in his life in Paris Clamence was initially both happy and virtuous.

Clamence was not in any way selfish: a sought-after lawyer, he represented the poor without recompense; he helped them, comforted them, consoled them. His happiness, moreover, had that cheerful resonance only because it rested on the 
Ph.D. Thesis - R. Srigley McMaster - Religious Studies

sense of duty and the practice of virtue. To be sure, there was nothing of the hero in him. But in the circumstances of the plague he would doubtless have revealed the hero who slept within him, exactly like Rambert and better than he, for Rambert was at the outset nothing but selfish. ${ }^{22}$

We can leave aside the lack of charity toward Rambert, who in fact is not selfish in Onimus' sense. ${ }^{23}$ Something does disrupt Clamence's happiness. He becomes disaffected with his life after failing morally in difficult circumstances. The way Onimus describes that failure makes it clear that it was not an isolated event. It becomes revelatory of Clamence's character per se.

Caught in the very act of mediocrity, he came to take a new look at his own being and his own behaviour; he found himself to be leprous and plague-ridden - the equal of all men. Then the sarcasm and scorn took hold in him: self-scorn and, more serious yet, scorn for humanity in general."24

The most obvious problem with Onimus' account is its inconsistency. He argues that prior to his fall Clamence was a genuinely virtuous human being. Yet he also claims that after the suicide Clamence realized that he was and always had been "plague-ridden," i.e, morally duplicitous and self-interested. These claims are not consistent, and together they make Clamence's actions psychologically and dramatically unintelligible. To state the problem simply: If Clamence were as selfless as Onimus says he was, he would not have hesitated to sacrifice his life to save the woman, just as Rieux, to whom Onimus implicitly compares him (he is the character in The Plague who is even "better" than Rambert), repeatedly puts himself in harm's way in order to save others.

I do not think that this inconsistency is the result of a failure of reason on Onimus' 
Ph.D. Thesis - R. Srigley McMaster - Religious Studies part, nor do I think it is idiosyncratic. Rather it stems from his use of the Christian historiography as a template for understanding the nature of Clamence's drama. Clamence, like all pre-Christian civilizations, appears to be good but is in fact bad because he lacks the revelatory insight afforded by Jesus's death and resurrection. Like those civilizations he lives in a kind of moral darkness for which he is not directly responsible but from which he suffers nonetheless. His awakening comes when he recognizes the true nature of his depravity and the impossibility of salvation through traditional virtues or means. Indeed he now understands these things to be not only insufficient but positively malevolent because they create an illusion of wholeness that obfuscates his true condition. But because Clamence, like the "stiff-necked" (Exodus 32: 9) Jews and the morally inferior Greeks before him, rejects that offer of salvation, he becomes anti-Christ, that is to say, demonically fixed in his opposition to any form of goodness and extraordinarily violent and cunning, a prime candidate for the ninth circle of hell. The madness we witness in him at the conclusion of the book is picture of his true condition and an anticipation of his eternal punishment.

The interpretation is seamless so long as one accepts the Christian narrative on which it rests. That narrative is so familiar to our ears that we barely recognize its presence. But if we stop for a moment and put aside our prejudices we will see that The Fall does not in fact fit this narrative pattern but rather challenges it. In his pre-fall state Clamence is not Greek or even Jewish but thoroughly Christian. He is an Augustinian 
Ph.D. Thesis - R. Srigley McMaster - Religious Studies whose life is organized according to the two loves described in City of God-amor dei and amor sui - albeit improperly. ${ }^{25}$ Clamence's fall does not change that; it makes him aware of its true nature, which until that moment had remained hidden from him. While it is true that this awareness affords him an opportunity for genuine improvement, that opportunity is not what Onimus imagines it to be. The "little ease" is not the natural condition of a human being but something Clamence comes to only after first rejecting the gentle nudges and benign laughter of the world that he initially experiences and which he identifies exclusively with Greece. ${ }^{26}$ Only then does he plunge headlong into the soul torments of the little ease that require the kinds of sophistic posturing Clamence engages in to be escaped. But this occurs only because Clamence does not choose wisely. Instead of rejoining the Greeks he returns to his old, Augustinian ways. But this time he does not do so innocently. Clamence now knows what he refuses, and the results are not easy to look at. The picture of him that emerges is the one promised by Camus in the book's epigraph: "a portrait, but not of an individual; it is the aggregate of vices of our whole generation in their fullest expression."27 The fully conscious Christian is a modern, and together these doctrines conspire to produce Clamence, the completely modern human being. Because Onimus conflates Clamence's initial awakening with the account of it he finally settles on, he ends up interpreting Clamence's worst moments as his best and paves the way for a Christian reading of the type I have just outlined. 
Ph.D. Thesis - R. Srigley McMaster - Religious Studies

Robert Solomon's recent book, Dark Feelings, Grim Thoughts: Experience and Reflection in Camus and Sartre, is a criticism of Christian and Augustinian interpretations like the one offered by Onimus. Solomon wants to replace these readings with an Aristotelian interpretation of The Fall that arrives at very different conclusions because it judges the character of Clamence's pre- and post-fall condition in relation to Greek notions of pride and virtue, and not by the standards of the Christian revelation.

For Solomon Clamence's pre-fall state was not the duplicitous and licentious affair that Clamence makes it out to be; nor does he consider Clamence's "innocence" naive or self-deceptive. Solomon argues that Clamence's early life in Paris was morally exemplary and that his innocence was a sign of his good faith or confidence. "I think the main point to make about Clamence is that in Paris, he is indeed a truly virtuous, fully contented, enviably successful man. His self-confidence is fully warranted."28 This bold claim challenges Clamence's own interpretation of his life. In order to make it convincingly Solomon must explain the elements of Clamence's character that seem anything but virtuous or proud in the Aristotelian sense. For instance, Clamence's treats women brutally, to the point of wishing for their deaths in order to satisfy a type of selflove that he claims would otherwise not be possible. ${ }^{29}$ Solomon is aware of this problem. His response is to encourage us to "bracket" such "insensitivities" on the grounds that they were common practice for Parisian men in post-war France. I doubt whether he is right. ${ }^{30}$ Camus himself was deeply troubled by his own behaviour in this regard. ${ }^{31}$ 
Ph.D. Thesis - R. Srigley McMaster - Religious Studies Moreover, whatever mid-twentieth century Parisian males might have thought about the matter, it is hardly consistent with Aristotle, Solomon's exemplar of Greek virtue, for whom an infidelity like adultery was never morally justified. ${ }^{32}$

There are further difficulties with the interpretation. Having argued for the virtue of Clamence's pre-fall state, the cause of his fall becomes hard to explain. In a common sense reading of the book the reason is straightforward: Clamence is always a duplicitous self-lover so the possibility of a fall, an awakening regarding the true nature of his condition, is always present. That awareness grows or deepens over the course of time, it is true. But it is provoked initially by a single event: Clamence's moral failure when faced with the suicide on the Pont Royal. Not so for Solomon. He questions whether the suicide ever actually occurred, citing the elliptical nature of Clamence's description of the event as evidence..$^{33}$ And he argues that whether or not it did occur is of little importance in comparison to the sheer fact of Clamence's changed disposition. As Solomon says, the cause of that disposition, the poisonous thought that finally unhinges Clamence, "is ultimately less important than the self-undermining, humiliating nature of the thought itself. ${ }^{\prime 34}$ Perhaps. But the suicide is not a minor event in the narrative. It is alluded to early on as the cause of the story that follows; ${ }^{35}$ it is described explicitly at the physical center of the book; $;^{36}$ and Clamence returns to it again at the end of his narrative in a last ditch but ultimately unsuccessful effort to escape his madness. ${ }^{37}$ And this is to say nothing of its relationship to the title of the book. Any interpretation that claims that the suicide is 
Ph.D. Thesis - R. Srigley McMaster - Religious Studies unimportant must nonetheless account for these facts. This Solomon does not do.

I think Solomon dismisses the woman's suicide in order to make his argument seem more plausible. One of the most important problems for his interpretation is precisely Clamence's behaviour on the bridge. To say it simply: if Clamence were as virtuous as Solomon claims he is, he would have jumped in after the woman. Or to cite Aristotle, virtue is habitual, and habits are not easily broken. But Clamence does not jump, and his failure to do so shatters the good opinion he holds of himself. And there we have his fall. Clamence acts virtuously when people are watching or when it serves his interest, but not when these things are absent. In order to limit the potential damage of such an objection, Solomon preempts it by creating a doubt in the reader's mind about the veracity or significance of perhaps the single most important event in the book. And he does all this in order to maintain that the duplicity and hypocrisy that Clamence discovers in himself is the "duplicity and hypocrisy of the critic Clamence, not any duplicity and hypocrisy on the part of the innocent Clamence."38

Solomon argues that in his post-fall condition Clamence is poisoned by bitter resentment. Instead of delighting in his own virtue or at least recognizing it frankly for what it is, he is plagued by a sense of inadequacy. Herein lies the source of his duplicity. Clamence thinks himself inadequate and is therefore no longer at one with himself. Solomon identifies three different sources of comparison that encourage that sense of inadequacy: himself, other people, and a transcendent standard of perfection or God. ${ }^{39}$ 
Ph.D. Thesis - R. Srigley McMaster - Religious Studies

Such comparisons are typical signs of resentment: the awareness of a standard of perfection one desires but cannot reach, and the corresponding effort to degrade that standard and to elevate oneself above it. ${ }^{40}$ Solomon claims that the first two sources of comparison are constant in human life and therefore must simply be resisted if one is to live free of resentment. The third is a different matter, and it is the most interesting part of Solomon's analysis.

Transcendence or God is a construction for Solomon. He does not say the same of resentment per se, but this is strongly implied by his analysis. At any rate, he suggests that Clamence's (and Camus') lingering belief in the Christian God might be what creates this duplicitous and resentful condition.

I think one apt diagnosis is that Clamence (Camus?) indulged in the wrong kind of reflection, reflection that was already tainted with the otherworldly, with comparisons and contrasts to perfection, and consequently with the seeds of failure and resentment. This is the cost of what Nietzsche called the 'shadows of God,' our continuing insistence on holding up superhuman ideals of perfection and then declaring ourselves failures or frauds in their reflection. ${ }^{41}$

Solomon softens the critique somewhat when he claims that the despair this awareness of God provokes "cuts at least two ways," one of which "urges us toward the Christian sense of redemption," the other to "reject that or any worldview whose consequence is that morbid sense of guilt and resentment. ${ }^{942}$ This nod to Christianity is a surprising concession on Solomon's part. His main argument is that Clamence's pre-fall condition is the equivalent of Greek pride or virtue in the best sense, and therefore 
Ph.D. Thesis - R. Srigley McMaster - Religious Studies preferable to his subsequent psychological turmoil and machinations. But if Clamence's post-fall duplicity is real and thus calls for something like Christian redemption, then it is superior to his pre-fall condition in which this awareness is lacking, just as some Christian commentators argue.

My guess is that this is a slip in the argument or perhaps a courtesy to Phillip Quinn. ${ }^{43}$ Solomon clearly interprets The Fall as a critique of Christianity. His guide in this regard is not so much the Greeks themselves as one of their most famous modern defenders - Nietzsche. Solomon argues that Clamence's fall is from Aristotelian pride to bitter Christian resentment. What else is that but a reworking of Nietzsche's historical and existential account of the transition between the Greeks and the Christians, particularly as he develops it in books like The Genealogy of Morals and The AntiChrist? Clamence is one of Nietzsche's noble Greeks, whose natural pride and good conscience are poisoned by the resentful slave morality of Christianity. Solomon takes the argument and uses it to explain the dramatic movement of The Fall. In doing so he turns the tables on the Christian commentators he is responding to by claiming that Clamence's recognition of his alleged duplicity and self-love is not the moral improvement they claim it to be, but a deplorable corruption of his virtue that may itself have been precipitated by Christianity. ${ }^{44}$

It is a clever argument, admirable for its boldness and for its attempt to take Camus' Greeks seriously. But there are problems nonetheless. By relying on Nietzsche's 
Ph.D. Thesis - R. Srigley McMaster - Religious Studies analysis to make his argument, Solomon repeats Nietzsche's mistakes and also does an injustice to Camus, who, though appreciative of Nietzsche's achievement, sought to go beyond him. ${ }^{45}$ It is absolutely true that Clamence has "Greek" moments, and that these are essential to understanding his character and the meaning of the book as a whole. Indeed they are the story's only true measure, as brief and provocative as they may be. But these moments do not occur in his pre-fall state. That is when Clamence is least like a Greek. It is, however, precisely the moment when he is most like what a Christian imagines a Greek to be.

According to the Christian teaching the Greeks have natural reason and an apprehension of the physical world, but they lack the supernatural revelation of love evident in the death and resurrection of Jesus. Christian writers differ about just what level of insight the Greeks were able to achieve without this revelation, but they all agree that they were incapable of faith and love in their highest sense. This is not to say that Christians dismiss the Greeks as immoral in the traditional sense. From Augustine to Kierkegaard Christians have been more than willing to acknowledge and in some cases to extol the ethical accomplishments of the Greeks. ${ }^{46}$ But their acknowledgment or praise has always been something of a Trojan horse. The words with which they venerate the Greeks are the same as those with which they destroy them. According to the Christian account the Greeks are virtuous, but virtue is pretty meager stuff in comparison to Christian faith - inadequate in its own right and a barrier to the highest revelations 
Ph.D. Thesis - R. Srigley McMaster - Religious Studies

because of the sense of self-sufficiency or satisfaction it encourages. This is Solomon's

pre-fall Clamence. What is interesting is that it is also Onimus':

Clamence was not in any way selfish: a sought-after lawyer, he represented the poor without recompense; he helped them, comforted them, consoled them...To be sure, there was nothing of the hero in him. But in circumstances of the plague he would doubtless have revealed the hero who slept within him, exactly like Rambert and better than he, for Rambert was at the outset nothing but selfish. ${ }^{47}$

Though Solomon disagrees with the Christian assessment of Clamence and of the Greeks generally, he does not disagree with its content. That is his mistake, which is also Nietzsche's. Solomon applauds the Greeks but sells them short at the same time. And in the process he distorts the meaning of Camus' book. The Greeks may offer less than the Christians when it comes to notions of redemption in a future life, and they may be less optimistic or sanguine about the harsher aspects of life. But here as elsewhere Camus argues that they are far more moral and their wisdom or prudence far more salutary for life than anything we find in Christianity. Solomon's interpretation retreats from Camus' best insight and does the Greeks a disservice by conceding too much ground to the Christian interpretation, even though this was not his intention. Moreover, in order to do so he must take liberties with Camus' book like those I discuss in relationship to Clamence's fall and the woman's suicide. None of this is necessary, of course. If we read The Fall carefully we will learn more about the Greeks than the Christians know or concede and we will come to appreciate the depth of Camus' critical analysis of both Christianity and modernity. It is best not to silence these things from the outset, even if it 
Ph.D. Thesis - R. Srigley McMaster - Religious Studies is in order to pay homage to the greatness of Nietzsche or to make a clever argument.

David Ellison's approach to The Fall is quite different from Onimus' and Solomon's. He wants to move away from the traditional categories used by these commentators in order to open up space for a Blanchotian or post-modern reading of the text. ${ }^{48}$ Ellison admits that many of Camus' previous works are characterized by a "sober lyricism" that is concerned more with moral content than is the self-reflexive literary complexity of the sort he finds in Blanchot. ${ }^{49}$ Following Paul de Man, Ellison says these early works are examples of a "humanistic existentialism" that favours content over form and has clear moral and political aims. ${ }^{50}$ But The Fall is not like these books, he tells us. Regardless of what Camus may have intended, ${ }^{51}$ Ellison argues that The Fall is playful, ironic, seditious, and dizzying in a way early books like The Myth of Sisyphus, The Stranger, The Rebel, and The Plague are not. ${ }^{52}$ It undermines our desire (and Camus') to master its meaning or the meaning of its subject matter and instead opens us up to the compelling but unnameable "void" or "primal source" that for Ellison and Blanchot lies at the heart of this type of literature..$^{53}$

I am not as concerned with Ellison's literary theory as I am with its implications for the types of political and philosophical problems raised by The Fall. Ellison, too, is concern about these problems, as was Blanchot himself..$^{54}$ But in Ellison's book they are subordinate to an argument regarding the potential of The Fall for developing "a theory of 
Ph.D. Thesis - R. Srigley McMaster - Religious Studies literary interpretation" concerned with problems of intertextuality and narrative form. ${ }^{55} \mathrm{I}$ want to set aside these literary concerns in order to explain the political implications of Ellison's argument and then to make a few critical remarks about the compatibility of that argument with The Fall itself.

Like the best post-modern critical theory, Ellison's interpretation opposes the totalizing aspects of modernity and the traditions out of which it has grown. Unlike modern and Christian narratives in which events or experiences line up neatly and provide a "logical coherence," Ellison argues that The Fall denies us these comforts and plunges both author and reader into a dizzying spiral that is without measure and which therefore cannot be mastered ${ }^{56}$ Modernity may be full of "inane chatter" and susceptible to the types of charges Clamence brings against it. But Ellison claims that the book contains a deeper sense of guilt or a "central void" that Clamence's critical assessment of modernity and himself is calculated to obscure. ${ }^{57}$ That void shatters all narrative coherence, including the narrative of modern guilt that forms the surface story of The Fall. What that narrative hides is another type of guilt, one that is even more tormenting precisely because it cannot be traced to an originating transgression or crime. As Blanchot writes of Clamence: "His confession is but a calculation. His guilty man's story is made of the hope of believing himself to be guilty, because a true crime would be a verifiable event in which he could anchor his life, a solid point of referential certainty [repère solide] that would allow him to limit his course." 58 There is nothing hidden or elusive 
Ph.D. Thesis - R. Srigley McMaster - Religious Studies about this sentiment. Clamence states it explicitly toward the end of his confession in contrast to the modern situation, in which people are deemed guilty in the absence of any law whatsoever. "He who clings to a law does not fear the judgement that reinstates him in an order he believes. But the keenest of human torments is to be judged without a law." Clamence's assessment of this situation is not favourable. Nonetheless Blanchot continues his analysis: "We fall. We console ourselves for this fall by determining, in our imagination, the point at which we presume to have begun falling. We prefer to be guilty rather than to be tormented for no crime. ${ }^{960}$

Ellison's argument requires some unpacking. Perhaps the best to way to approach it is to explore the dual account of the self he finds at work in The Fall. On the one hand there is what Ellison calls the "authorial" self who seeks to master the content of the text but also his political and social relations. The aim in both cases is the imprisonment of the other. ${ }^{61}$ Ellison sees evidence of these ambitions in Clamence's attempt to pin down the cause of his guilt and in his preference for domination in his relationships to women and in war or politics. ${ }^{62}$ On the other hand there is the "transsubjective dispossessing generality," not a controlling self in the first sense but one who participates willingly in the dizzying movements of the text and the fascinating play of the game that is life. ${ }^{63}$ This second self "'loses himself" in the playing. The truth of the game takes on the form of an ironical reversal in which the manipulator of figures is himself manipulated. In Gadamer's succinct terms, the fascination of game playing is that the game becomes 
Ph.D. Thesis - R. Srigley McMaster - Religious Studies master of the player." ${ }^{94}$ Ellison uses a variety of images to illuminate the experience of this second self, but what they all point to is a relinquishing of control and a willingness to be moved, shaken, and troubled by a presence that demands interpretation but remains forever elusive or unnameable. ${ }^{65}$ Although Clamence's aim is to "implicate the reader in his own personal degradation, to draw him into the tightly constricted space of an individual discourse" (the first self), the text also moves in another, very different direction (the second self): "it forces Clamence into a strange realm of transindividual generality that surpasses his egocentric limits; it thrusts him into dizziness. ${ }^{966}$

Ellison sees in The Fall an example of the now familiar post-modern attempt to restore an experience of the "other," both in the eminent sense of a missing or "absent center" and in the more common meaning of the many people and things we encounter each day ${ }^{67}$ Though he does not say so explicitly in his analysis, the immediate political context of this longing for the other is the nightmare of modern totalitarianism, which attempted to extinguish or destroy otherness absolutely in favour of a complete rationalization of human life. ${ }^{68}$ Trading in a deadly and lonely mastery for a giddy and dizzying fall into a greater reality that undermines all forms of oppression certainly seems like a good bargain, and it explains in large part the appeal of post-modern thought generally. Compared to the stiflingly moralistic atmosphere of late modernity, at least this sounds fun. But despite Ellison's best intentions, his solution to the crisis of modernity carries within it the disease it seeks to overcome and fails to equal the depth of insight of 
Ph.D. Thesis - R. Srigley McMaster - Religious Studies

Camus' book.

Despite its anti-Christian orientation, Ellison's interpretation of The Fall repeats the Christian problematic that Camus himself sought to criticize and overcome. The idea of a pervasive guilt from which human beings suffer but which they can neither define nor determine the cause of is not an antidote to Clamence's desire for mastery but the sentiment that makes that mastery possible. Its proper or doctrinal name is original sin; in Clamence's vocabulary it is called the "little ease." This is Clamence at his worst. The sense of guilt expressed and encouraged by his account of the little-ease is a perversion of his best insight into his condition after his awakening. Once he decides against that insight, he discovers the advantages of provoking a similar sense of guilt in others. It satisfies his lust for domination and alleviates his own guilt somewhat by creating the illusion that his confession makes him morally superior.

Camus was highly critical of the notion of original sin in the Christian sense, ${ }^{70}$ and he would have had little sympathy for Ellison's and Blanchot's post-modern reformulation of the doctrine. Ellison's analysis is much more philosophically sophisticated than the Christian account, certainly, but on the level of experience it is the same thing. And there are even more parallels between the two narratives than this. Ellison refers to the book's obvious literary sources and the details of its narrative structure as surface meaning. ${ }^{11}$ Such meanings are equivalent to the book's content. However, following Blanchot, Ellison want to overturn "the traditional priority of content 
Ph.D. Thesis - R. Srigley McMaster - Religious Studies over form" by demonstrating "the insubstantiality of content itself," that is to say, by showing that content is contentless. ${ }^{72}$ This is pretty close to empty speech, but there are at least two ways to make it seem plausible. First you can analyze a text in such a way that it seems contentless in the traditional sense. Second you can claim to have discovered a deeper meaning or movement in the text that the surface meaning conceals or obfuscates. Ellison employs both techniques in his interpretation of The Fall. The dizziness to which he repeatedly refers as a fundamental feature of the book is an example of the first way. The problem is that this dizziness is not in or caused by the text itself but is an experience that Ellison attempts to create by means of his own dizzying or circular language. Most people who read The Fall (particularly men) become anything but dizzy in the existential sense as a result. To the contrary they become immensely sober. Not moralistically, but in the sense of, say, Shylock in The Merchant of Venice, whose sobriety makes him immune to the sounds of "shallow foppery" of his Christian hosts. ${ }^{73}$ Reading Ellison's book has the contrary effect. His words do make you dizzy, and they eliminate or discourage the moral sobriety that lies at the heart of The Fall.

As to the second technique, it is not clear what meaning remains once the priority of form and content are reversed. Does Ellison mean that form now becomes the content? Probably he does not. What is more likely is that content is eliminated entirely in favour of something that is considered to be more primordial yet still not substantial in the metaphysical sense. I think this is what Ellison means when he says that at the center of 
Ph.D. Thesis - R. Srigley McMaster - Religious Studies

The Fall there is not even an "enigmatically nonpresent presence" but only "a fleeing motion that lends itself to an allegorical correspondence with the temporal process of reading." ${ }^{.74} \mathrm{~A}$ nonpresent presence still sounds like metaphysics, while an "allegorical correspondence with the temporal process of reading" does not sound like anything at all, and so gives the impression of having escaped the traditional problematic completely. ${ }^{75}$

As I have said, I am sympathetic to Ellison's attempt to overcome readings of The Fall that assume a traditional or totalizing metaphysics as their foundation. But I do not think he quite makes it. His distinction between surface meaning and the "fleeing motion" that underlies it is simply a reformulation of the Christian doctrine of divine providence, in which the world that we experience immediately is made subordinate to the workings of a mysterious divinity that is its true meaning but which is not subject to any normal human judgement. In The Rebel Camus says that the effective truth of this practice is to "empty the world of its substance" and to encourage the kind of intellectual dishonesty that characterizes modern and Christian providentialism. ${ }^{76}$ In support of the claim, he cites Marx's notion of the "objective criminal" and also a passage from Saint Ignatius' Spiritual Exercises concerning subservience to the Church, the temporal representative of divine providence on earth: "We should always be prepared, so as never to err, to believe that what I see as white is black, if the hierarchic Church defines it thus." ${ }^{277}$ In such accounts the surface of the world disappears and reappears as needed in order to fit the structure of the doctrine. Whatever dizziness one might experience here is due to the 
Ph.D. Thesis - R. Srigley McMaster - Religious Studies

sophistry of this type of speech, which aims to confuse the mind and the heart, not to

some underlying void and absence or fleeing motion.

In Ellison's interpretation, just as in Solomon's and Onimus', the aspect of the world's surface that is first to go is its moral character. By the time Ellison has completed his analysis of Clamence's encounter with the suicide on the Pont Royal the moral failure it brings to light has been transmogrified into an empty but vaguely exhilarating metaphysical absence. It is worth quoting Ellison in full here:

The most apparent effect of the episode is to inculpate Clamence, to condemn him for lack of action. He has seen a woman, heard a suspiciously revealing noise, and has not shown the slightest sign of altruistic behavior. He has allowed a suicide to occur, the critics tell us. But what is the textual origin of this 'death'? A literal reading of the passage reveals only a series of juxtaposed perceptions: the protagonist sees a woman who appeals to him sensually and then he hears the sound of a body followed by a cry. The rhetoric of Clamence and the logic of referential anchoring cause us to combine these elements into a coherent picture: we conclude quickly that it is the woman seen on the bridge who falls and that her death is Clamence's crime of passivity. The text is persuasive enough to render all this believable and pathetic. On the purely literal level of the discourse's immediate significance, however, the dramatic center is nothing more than the enigma of an invisible absence that, through the subject's erroneous interpretation, becomes clothed in the language of guilt. ${ }^{78}$

So much for the shame Clamence experiences over his cowardice and the resulting psychological disturbances that ultimately destroy him. And so much for the woman!

Onimus' rather sanguine lament about the inescapable evil of our condition and the misery to which flesh is heir is not encouraging in this regard; Solomon doubts whether a woman actually killed herself, all the better to make Clamence's pre-fall nobility seem 
Ph.D. Thesis - R. Srigley McMaster - Religious Studies plausible; and Ellison, as if working out the details of the modern account, sees no event at all but only an painful "invisible absence," that is to say, an experience. Of course The Fall is only a book; and in literary interpretation, anything you can get away with is acceptable. But as Orwell said, you cannot get away with much. The manner in which these commentators treat a fictional female character is more than a little disturbing if we imagine a context in which the act were made real. In each case we see a striking example of how the moral world disappears in preference of some other kind of concern or experience that is considered truer and therefore more important than what is actually happening before us. This is nowhere so clear as in Ellison's analysis.

In Christianity faith is a more basic requirement than works. Perhaps there is no true faith without works. But works are absolutely impossible without faith. The idea of works already alters the Greek notion of virtue because of its relationship to faith. But once faith supercedes both works and virtue the center of our moral life is altered and achieving the right experience or sentiment in relation to God assumes primacy of place. Camus explored this shift in meaning early in his career. In Christian Metaphysics and Neoplatonism he describes the advent of Christianity in this way: in a world "in which the desire for God is getting stronger, the problem of the Good loses ground." ${ }^{.79}$ Though there is no God in Ellison's interpretation, the shape and consequences of his analysis are essential the same as those we find in the Christian account. The moral content of The Fall is either thinned out or explained away in preference of an experience that Ellison 
Ph.D. Thesis - R. Srigley McMaster - Religious Studies describes in a number of different ways. But in each case the decisive difference lies in the fact that these intense experiences make no moral demands. One has them and thus feels closer to the nameless "center" out of which books like The Fall arise. One still may experience guilt, but this guilt has no identifiable cause and therefore no justification. What could be more pleasant? It is not accidental in this regard that all the images Ellison and Blanchot use to describe The Fall could equally describe what happens to you at an amusement park. Lots of dizziness and lots of intense experiences, and lots of excess too. But no quibbling about morality please, because now is not the time for such seriousness. One is on vacation after all. This is a good indication of what post-modernity offers: in place of the deadly nihilism of early modernity it offers a playful version in which the premises have not really changed but where the violence of improvement has been sacrificed to our seemingly insatiable desire to be amused. It is the Disneyland of the soul - the pastime of aging adolescents that tells us nothing we need to know about either The Fall or the experiences it explores.

I disagree with these interpretations of The Fall in large part because of their misreadings of Clamence's pre-fall life in Paris. The misreadings are not by any means the only or even the most important ones. But they tend to have a cascade effect that forces each commentator to interpret subsequent stages of Clamence's life in ways that are consistent with the beginning he posits, often in flagrant disregard of the facts. This 
Ph.D. Thesis - R. Srigley McMaster - Religious Studies makes it a reasonable place to begin.

To state my disagreement simply: I think Clamence starts out neither as a modern nor as a Greek but as a Christian, complete with Christian ambitions and Christian sensibilities. Clamence is absolutely vigilant about doing good deeds. He never passes up an opportunity to act selflessly, particularly in public. The problem is that he does all of this for purely selfish reasons ${ }^{80}$ It is true that for a long time he is strangely unconscious of his real motives. But that ultimately changes, as one would expect it to. These things have a way of coming out. And in any event it does not alter the basic character of his life. Clamence is a Christian whose self-love is forever highjacking his love of God and his love of others, even though he remains for some time unaware of that fact.

The best comparison we can make here is with another Christian figure who struggled with the problems of amor Dei and amor sui - Saint Augustine ${ }^{81}$ Like Clamence's narrative Augustine's Confessions is a report of his struggle with self-love and a description of the manner in which it constantly worked to undermine his love of God. ${ }^{82}$ The fact that the Confessions is written in the first person suggests that it is also an attempt on Augustine's part to purify himself of that self-love and to escape the tormenting duplicity in which it involved him. ${ }^{83}$ The same is true of Clamence. Clamence and Augustine are not intellectuals. They are highly erotic human beings whose struggles and ambitions extend far beyond the concerns of those who merely write books. ${ }^{84}$ And the similarities between them do not end there. Both employ confession as a means of 
Ph.D. Thesis - R. Srigley McMaster - Religious Studies coming to terms with their self-love. And they are compelled to confess similar things: erotic excesses and improprieties, a lust for experience that tends toward a neglect of the other, and a disturbing tendency to ascend to the highest things only quickly to turn their backs on what they have learned or to use it for questionable purposes. ${ }^{85}$

In addition to these thematic similarities there are also a number of textual ones between The Fall and the Confessions. The self-interest or lust that characterizes Augustine's relationships with women is also what characterizes Clamence's relationships. Both men respond to the deaths of others with something close to enjoyment while being plagued with fear at the thought of their own mortality. Both narratives record a theft that illustrates the nature of evil in some measure. And in both cases the predominantly Christian orientation of the account is briefly interrupted by a discussion of the Greeks that ultimately proves ineffectual in changing the direction of the narrative. Though the meaning of that interruption in The Fall is different from what it is in the Confessions, in both instances it is followed by a definitive reassertion of Christian truth that quickly brings all discussion to an end. In Augustine's case it comes in the form of his conversion narrative ${ }^{86}$ in Clamence's through his critically admiring portrait of Jesus and his claim to have brought the proliferation of modern Christs to an end through the advent of his own "solution, truth at last..."87 There is even a charming allusion to a similarity in vocations: Augustine's appointment as Bishop of Hippo is mirrored in Clamence's brief stint as pope in a German POW camp in North Africa, where his duties 
Ph.D. Thesis - R. Srigley McMaster - Religious Studies were largely taken up with negotiating between competing "political and sectarian" groups. $^{88}$

All of these similarities are important, but there is another that is even more significant and that sheds light on one of Camus' most important insights in The Fall. Augustine's struggle with self-love is in part merely an instance of the normal human difficulty of overcoming self-interest in order to see and do what is best or most fitting in a given circumstance. This seems hardly true of Clamence, who does everything in his power to ensure that his self-love increases without restraint. Perhaps. But I think that in The Fall Camus has put his finger on a similarity between the two men that suggests a far more troubling insight regarding the nature of the Christian teaching and its relationship to modernity.

Upon first becoming aware of the nature and extent of his self-love Clamence is deeply shaken. His good opinion of himself collapses and he is left to wonder how he will ever recover. ${ }^{89}$ The same is true of Augustine. ${ }^{90}$ For both men the ensuing struggle results from the resistance their self-love puts up to the proper sorts of love they have begun to understand and which they feel growing within them. In Clamence's case it is self-love that finally wins out; for Augustine the opposite seems to be true. But this is not so. By matching the two men in these and other ways Camus points to a fundamental sameness between them that is not diminished by the fact that they hide their duplicity in different ways and use different symbols to express their self-love. Clamence accomplishes what 
Ph.D. Thesis - R. Srigley McMaster - Religious Studies Augustine accomplishes, but he is even more successful than Augustine because he has perfected the art of seduction inherent in the act of confession ${ }^{91}$ and because he does not have to contend with the counter-influence of a genuinely alternative tradition. Christianity had already accomplished that task for him..$^{92}$ If we combine these historical insights with the structure of The Fall itself, we could say that Augustine's condition after his conversion is equivalent to Clamence's condition before his fall; and Clamence's post-fall resolution to pursue his self-love to its final term is the fulfillment of the Christian teaching implicit in Augustine's account, but which for Augustine never reaches its fullest expression. In other words, according to the argument of The Fall Christianity is a form of self-love that is continued in modernity, rather than the usual account in which it is taken to represent a pure (though perhaps impossible) expression of human and divine love that is later abandon or corrupted by moderns.

If the above comparisons work, then there is a further one we can make. If the preFall Clamence is Augustine or Christianity, then the post-fall Clamence is Machiavelli or modernity. Though there are no explicit textual references to Machiavelli in the book comparable to those I have noted in regard to Augustine, there is a substantial or thematic parallel to Machiavelli's account that is just as important. Christianity conceals its selflove beneath the veil of the love of God, just as Clamence conceals his self-love beneath his morally exemplary behaviour. Both do so for an obvious reason: self-love's interests are rarely well-served by announcing its ambitions publically. Though people's lives are 
Ph.D. Thesis - R. Srigley McMaster - Religious Studies often guided by such ambitions, they usually think it best to keep them hidden.

One interpretation of Machiavelli is that he merely had the courage to say publically what everyone else thought privately. This is certainly true in one sense. But I think his account is more subtle and complicated than that, ${ }^{93}$ and that its subtlety and complication are shared by Clamence and can be illuminated through a comparison with him. Or the other way around. Because Camus was as much a critic of modernity as he was of Christianity, Clamence's story illuminates the true nature of Machiavelli's project as much as or more than it is illuminated by it. But first Machiavelli.

Machiavelli unmasks the self-love that he claims animates Christianity just as it animates all human endeavours. Behind its pious exterior Christianity is as self-interested as any worldly prince or political party. This does not mean that Machiavelli wishes to abolish religion or to reform it. Since for him self-love is both universal and inescapable, he is not surprised to find it here as much as in politics or economics. Still, he claims that religion is useful in politics as in life because people tend to judge by the appearance of a thing and not by its reality. ${ }^{94}$ The only superiority Machiavelli seems to allow religion generally and Christianity particularly is that it is more adept at achieving its goals and satisfying its ambition because it is better than other traditions at concealing the truth about its nature. This idea is stated explicitly in Book XVIII of The Prince, ${ }^{95}$ but it is perhaps nowhere better illustrated than in the story of Borgia exploits in the Romagna that Machiavelli relates in Book VII. ${ }^{96}$ At any rate, the Christian "sect" has lasted longer 
Ph.D. Thesis - R. Srigley McMaster - Religious Studies than any principality or civilization we know of. Perhaps it has understood the art of mastery or war even better than the ancients whom it superceded.

The comparison with Clamence's account should be obvious. Clamence in his post-fall formulations repeats Machiavelli's insight and also his defense of self-love at the same time that his drama as a whole mirrors the historical transition from Christianity to modernity. Clamence's awakening to the true character of his life is equivalent to Machiavelli's insight into the self-love or self-interest that underlies the Christian teaching. That is the first moment of his awakening, which is open to a number of different responses. Clamence ultimately settles on one. He chooses to pursue his selflove actively and consciously rather than to explore the criticism of it inherent in his awakening. That is the modern response. Though moderns recognize the self-love inherent in the Christian account, the account they offer in its place merely repeats the same pathology in different words. Of course, here also there are different possible responses. Some modern formulations mimic the Christian teaching right down to its unconsciousness regarding its true nature and ambition. This is the ideological or revolutionary wing of modernity which is as full of true believers as any church has been. Clamence may admire the "diligence" and "methodical patience" of such types - Hilter and the Nazis are his favourite examples - but he is nonetheless not quite one of them. ${ }^{97}$ Clamence is far more reflective than these people about the nature of the project in which he and they are engaged. 
Ph.D. Thesis - R. Srigley McMaster - Religious Studies

I think Clamence belongs to the cynical wing of modernity represented by Machiavelli. By calling it cynical I do not mean that it is true or realistic. Whatever real insights there may be in Machiavelli's and Clamence's accounts, both ultimately rest on a misunderstanding of human experience. The Fall brings that misunderstanding to light at the same time that it traces its historical source. Clamence like Machiavelli seeks to confirm the idea that life is self-love and nothing but self-love by demonstrating that all other forms of love can ultimately be reduced to it. To do so he brings to light the selfinterest that is often hidden beneath our seemingly noblest aspirations. But Clamence does not do this work of demystification because he desires to know the truth about the human condition. His aim is just the opposite. His account is designed to enhance and further his self-love by creating the illusion that self-love is the only game in town. This is also Machiavelli's strategy. In The Fall Clamence's notion of human duplicity is gradually reconfigured to mean a hypocritical unwillingness to acknowledge one's selflove rather than an experience of being drawn in two real and genuinely different existential directions. ${ }^{98}$ Moreover I think the reason Clamence does these things is that he desires the same apocalyptic freedom from the human condition that Christianity had promised and which moderns have been unwilling to relinquish. Here too modernity merely repeats the Christian account. "Ah, the little sneaks, play actors, hypocrites - and yet so touching! Believe me, they all are, even when they set fire to heaven. Whether they are atheists or churchgoers, Muscovites or Bostonians, all Christians from father to 
Ph.D. Thesis - R. Srigley McMaster - Religious Studies

son."99

There is one bright spot in this otherwise dismal story. It occurs initially at the moment of Clamence's first awakening, but it can also be found in several of his later insights. If we read the text closely it becomes apparent that the ways in which Clamence ultimately interprets his fall are not consistent with the nature of the experience as he initially describes it. Subsequent formulations like the "little-ease" are not empirical descriptions but constructions designed to make the turn toward self-love on which Clamence ultimately insists seem both compelling and inevitable. But before this turn there is a brief moment during which he sees his situation differently and to which he alludes periodically over the course of the narrative, as well as to a number of other comparable experiences. In this moment he experiences the judgement of his self-love but he is not crippled by it; and he is certainly not overwhelmed by the same sense of horror that later will encourage his most excessive apocalyptic solutions. To the contrary the judgement he experiences restores a sense of proportion or measure that is the very antithesis of such apocalyptic aspirations, and this goes as much for his good deeds as for his bad ones. ${ }^{100}$

In terms of the analysis' historical implications, I would say that Clamence's initial awakening is Camus' way of arguing that the apparent hegemony of the Christian/modern paradigm is only that - apparent. Or in slightly different words, the critique of Christianity does not lead necessarily to modernity, as Clamence and other 
Ph.D. Thesis - R. Srigley McMaster - Religious Studies moderns would have us believe. Between the two lies the genuinely other - the Greeks who are always there within us somewhere as the source of our best resistance to the times, but whose critical insights are always in danger of being drowned out or coopted for purposes antithetical to their own. It is true that the Greeks get only minor billing in The Fall. But when they do appear they are associated textually and explicitly with what is best in Clamence; and however limited their influence may be, the dramatic structure of the narrative makes it clear that the nightmarish vision that finally prevails in the book is the direct result of Clamence having abandoned them. ${ }^{101}$

There is one final feature of my interpretation that I should mention before turning to the details of the analysis. The Fall is a remarkably polyphonic work. In it Camus manages to respond to a host of problems and competing voices with a great economy of means. However one of the voices that commentators never mention is Camus' own. I do not mean this in the autobiographical sense. There has been plenty of work done on that problem. What I have in mind is the textual relationship between The Fall and Camus's previous books. Sorting out the nature of these relations in a comprehensive way is the task of the conclusion of this thesis. But there is no reason why certain portions of the overall structure cannot be worked out in advance. The Fall marks a significant departure for Camus, as I have said. Though The Myth of Sisyphus and The Rebel had been partially successful in describing the nature of the modern project, they came up short analytically at the crucial point. The Fall rectifies that problem, and it does so consciously by 
Ph.D. Thesis - R. Srigley McMaster - Religious Studies subsuming the arguments of these two previous works (and by implication the cycles of books they represent) into its own analysis in a way that indicates the nature of their limitations. One of the ways in which it does so is by taking the themes of these previous cycles and organizing them in reverse order to the chronological sequence in which they originally appear. In the chronology of the cyclical books it is suicide first (The Myth of Sisyphus), murder second (The Rebel). In The Fall Camus reverses the order: first murder, then suicide. But he does not stop there. That gets him only as far as the "vestibule of hell." 102 He must now turn to the darkest part of the problem and explore the true nature of modernity in its fullest expression.

The same reverse movement is also apparent in the analyses of the cyclical books themselves. ${ }^{103}$ Here it occurs in a microcosmic form that is meaningful on its own terms but also points to that broader structure. At any rate, if we put the actual chronology of the books together with the reverse order of The Fall, we get the following argument: Camus completes the critical analysis of modernity not by exploring it as a consequence of rebellion but by retracing his steps back through rebellion and the absurd to an original beginning from which these later experiences have emerged and by which they can best be judged. I think that for Camus the name of that beginning is love. It is the subject of his first books and its traces are evident in everything he wrote subsequently. ${ }^{104}$ In The Fall he explores its nature concretely and also gives the reader a clue as to its place and importance in his work as a whole by means of these additional structures. 
Ph.D. Thesis - R. Srigley McMaster - Religious Studies

First a rough outline of the general structure of The Fall. Chapters one to three offer a description of modernity mixed together with an account of the unreflective or pre-fall stage of Clamence's life. They end with Clamence's retelling of the story of his fall and his entry into a new dispensation. Chapter four explores the unraveling of Clamence's old life as he attempts to come to terms with the insight that characterizes this new dispensation. Initially he is deeply troubled by it and his responses reflect the ambiguity and ambivalence he experiences. They range from shame to defiance, and from genuine remorse to sophistic maneuvering. ${ }^{105}$ However by the conclusion of the chapter all ambiguity has vanished and Clamence has made up his mind about the meaning of what has happened to him. Nonetheless a solution to his crisis still eludes him. Chapters five and six are devoted to an explanation of that solution, but the answer does not come at once. First Clamence describes his attempt to silence the laughter and preserve his selflove through debauchery. ${ }^{106}$ This attempt fails. He then reformulates the nature of his condition in a way that both heightens the crisis and lends credibility to apocalyptic solutions of the type he will ultimately offer. ${ }^{107}$ In the final pages of the book Clamence describes that solution itself. He becomes a "judge-penitent," one who appears able to satisfy the demands of conscience while simultaneously pursuing a self-love that is its antithesis. ${ }^{108}$ Despite its apparent effectiveness Clamence admits that his solution "is not the ideal." 109 The book ends with a painful lamentation and an intimation of the madness 
Ph.D. Thesis - R. Srigley McMaster - Religious Studies to which this effort leads him. ${ }^{110}$

As I have said the first three chapters of The Fall are largely taken up with a description of modernity. Clamence takes the reader on a tour of the modern world with all its crimes and excesses, mixing that description with an account of his own pre-fall life and suggesting occasionally his admiration for those ambitions and his desire to perfect them. He praises the "methodical patience" of the Nazis as they deport or assassinate seventy-five thousand Jews in Amsterdam alone, and a few pages later he claims that he himself "was aiming higher."111

Everything Clamence says or does is an expression of his post-fall resolution to perfect his self-love, even his description of his pre-fall life. ${ }^{12}$ That is the back story of the narrative to which Clamence periodically alludes and that he states explicitly in the closing pages of the book. ${ }^{113}$ What this means is that everything he says is calculated to corrupt or deceive his listener and to satisfy and enhance his self-love. His aim in doing so is clear. By mixing his description of the horrors of modernity with an account of his own unreflective life he draws the listener into the narrative and encourages him to engage in the same type of reflection. The aim is to implicate him in the same crimes and excesses and to shatter the good opinion he holds of himself. Clamence can then lessen the judgment he experiences in himself by extending it to others and by rising above them as their judge because of his own more highly differentiated and reflective selfknowledge. 
Ph.D. Thesis - R. Srigley McMaster - Religious Studies

But this is a confidence game. Clamence must tell his mark enough of the truth to get the hook firmly in place. The mirror he holds up to others would be ineffective if it failed to reflect back to them what they actually are. So despite his deceptions and ulterior motives the description of modernity that Clamence offers in these opening chapters is remarkably astute. Properly read we can learn a great deal from it about the modern project without falling prey to his machinations.

The Fall makes it clear that Clamence is motivated in all circumstances by selflove. Clamence himself makes the claim repeatedly and explicitly throughout the narrative. ${ }^{114}$ If we put this together with Camus' argument in the epigraph that Clamence is an image of the "aggregate of vices of our whole generation," we get the further claim that the vices of modernity and indeed modernity itself are best understood as the expression of an extreme form of self-love. On the personal level the analysis is immediately compelling. Most of us have met such a person and the psychological description and judgment seem absolutely sound. But when we extend it to include broader political and social movements like modernity itself we begin to have reservations and we doubt the analysis' explanatory power if not its truthfulness. Is it really that clear? Are the complex political movements and regimes of our time really best understood as expressions of self-love? Is that not too simple and even moralistic to describe the rough and tumble world of modern politics?

The short answer to these questions is yes, but we need to clarify the meaning of 
Ph.D. Thesis - R. Srigley McMaster - Religious Studies Camus' argument in order to make it seem as compelling as it actually is. Perhaps the most significant barrier to understanding it is our common belief that politics is and always has been by nature a matter of self-love or self-interest and therefore cannot be criticized reasonably on such grounds. In personal morality and private dealings self-love may be as pernicious and destructive as Clamence' narrative suggests. But when it comes to politics it is the order of the day and cannot be suspended without the most terrible consequences ensuing. In this area of life Clamence's most cynical admissions are absolutely true, we think: in politics there are no friends in the true sense, only enemies and accomplices. ${ }^{115}$ In other words, we believe, with Machiavelli, that politics, if not life itself, is as Clamence describes it, and so we find Camus' critical argument unconvincing. And there is another related interpretive problem that makes the case against Camus seem even more compelling. If Machiavelli and Clamence are right and politics is nothing but self-love in action, then Camus' critical assessment of modernity begins to sound remarkably Augustinian. Augustine's modern defenders have argued that the madness and violence of modernity stem precisely from its devotion to amor sui. ${ }^{116}$ For Augustine this is the love that characterizes the earthly or worldly city. ${ }^{117}$ Modernity promotes its self-love or self-interest and abandons the ethic of self-sacrificial love taught by Jesus. Its attempts to achieve political stability and real peace fail because self-love and communal order are antithetical and because the source of its order is human rather than divine. And there is a further implication for Camus' argument. If the Augustine 
Ph.D. Thesis - R. Srigley McMaster - Religious Studies comparison works, then Camus' critique of modernity begins to look like a rather conventional Christian argument in which modernity is a departure from or corruption of the Christian teaching, not its fulfillment.

Camus did not overlook Machiavelli's insight nor did he merely repeat Augustine's Christian critique of modernity. Camus recognized that in politics as in life a measure of self-love is inescapable. But he never allowed that recognition to distort or mitigate dialectically his experience of the good nor to lead him to abandon his pursuit of the best regime and the best life. Contra Machiavelli Camus did not think that self-love is the only genuine human desire (which is remarkably close to the Christian account of our fallen nature), nor was he as sanguine as Machiavelli about the benefits of a regime devoted solely to its fulfillment. Clamence is the human face of that ambition, and his politics are not encouraging in this respect. Moreover, although there is a prima facie similarity between Augustine's amor sui and Camus' self-love, they are not the same thing. Camus was as good as Augustine at describing the clever workings and hidden places of human self-love. But his analysis goes further than Augustine's because it also accounts for the hidden place that goes by the name of Christianity and its several modern derivations. For Camus Augustine's amor Dei too is a form of self-love. A critique of modernity based on that analysis is ineffectual because it merely repeats or encourages the same existential disposition that it claims to criticize. Or as Clamence himself laments, "We shall never get out of this immense holy-water font." 
Ph.D. Thesis - R. Srigley McMaster - Religious Studies

In The Rebel modernity is sometimes described as a genuine or true desire for salvation that has merely gone wrong or become excessive. The main problem with the analysis is that it leaves the apocalyptic character of the desire untouched. This is why Camus is unable to complete the argument in that book. Every time he comes close to doing so the metaphysical need or void on which that desire rests reasserts itself and the reader is left thinking that any true solution to the problem must bear the shape of the Christian or modern apocalypse, if not their content. This explains the anti-apocalyptic apocalyptic character of The Rebel's argument. But not so in The Fall. Here the apocalyptic desire is itself subject to critical analysis. Camus argues that far from being a genuine desire for salvation, it is a refusal of whatever real salvation is possible for human beings in favour of another kind of satisfaction, one that gives the appearance of moral seriousness while denying or repudiating everything that real moral seriousness demands. According to Camus the proper name for that satisfaction is self-love, and it animates the modern project as its driving force. Clamence sketches its basic character in a number of episodes in the first three chapters of the book.

Clamence claims that the modern world is a "madhouse." 119 Its madness is apparent in a phenomenon that he describes across several areas of human life - politics, personal relationships, culture, and intellectual life. That phenomenon is the sustained modern effort to make reality or the real disappear. By matching that effort with a 
Ph.D. Thesis - R. Srigley McMaster - Religious Studies description of his own life, Clamence makes it clear that the engine of the disappearance is a self-love that has grown to extraordinary proportions.

Clamence makes the argument commonsensically and I will try to do so too. Selflove is a preference for one's own or one's own experience over the needs and concerns of others and the world. Though a measure of that concern is both necessary and inescapable in life, it can also become disproportionate and distorted. In certain of its expressions the world and others become little more than occasions for one's own satisfaction. This is not merely a problem of excess; it marks a different disposition toward things that seeks something other than the benefits of normal self-interest. In every day speech we call it "using" someone or something. The term is apt and it is well

. illustrated by Clamence's treatment of women, whom he keeps in the "refrigerator" in order to have them handy should he need them. Self-love on this scale deprives others of their independence and of the free movement of their desire. Clamence describes its ambition this way:

I could live happily only on condition that all the individuals on earth, or the greatest possible number, were turned toward me, eternally in suspense, devoid of independent life and ready to answer my call at any moment, doomed in short to sterility until the day I should deign to favor them. In short, for me to live happily it was essential for the creatures I chose not to live at all. ${ }^{120}$

This solution is something of a compromise. Clamence allows people to live, but they are effectively dead, having their lives solely from him. However a page earlier he does not want to grant them even that small concession. He says that what his self-love 
Ph.D. Thesis - R. Srigley McMaster - Religious Studies really demands is "the death of everyone" or to "depopulate the planet." Why? Because that is the only way for him to "enjoy a freedom that cannot be imagined otherwise." 21 The uninterrupted experience of oneself alone is not possible as long as others continue to exist and not simply to be deprived of independent life. Clamence learns this from experience. A passive young woman whom he initially dominates effortlessly turns out to have a voice of her own after all. ${ }^{122}$ After their break-up she points out his deficiencies to a third party. Of course Clamence does not allow her action to go unanswered. He wins her back immediately in order to brutalize her and humiliate her into what he hopes will be a lasting silence. But what he discovers along the way is that so long as people are alive their silence is never absolute. It is always possible that a real word or deed might slip through and disrupt the illusion of perfect freedom that self-love demands. Death is the only reliable solution, provided the dead do not talk also. "Her death would, on the one hand, have definitely fixed our relationship and, on the other, removed its compulsion." The only things that keep Clamence from that solution are his "sensibility" and his "love of mankind." 23 In the twentieth century there will be many who are untroubled by either sensibility or scruple and who will act ruthlessly where Clamence himself hesitates.

The political expression of modern self-love has two forms that correspond roughly to the two different means of silencing reality that Clamence describes in relation to women. Modern totalitarian regimes handle dissent through an ethic of mass killing, 
Ph.D. Thesis - R. Srigley McMaster - Religious Studies though they also practice coercion. Clamence's favourite example of this type of regime is the Nazis, though the Soviets under Stalin would illustrate the point equally well. ${ }^{124}$ The Third Reich engaged in mass executions for many reasons, but the main one was to purify the society of elements deemed unfit for life within it. Its aim in doing so was to establish a total regime whose organization would be seamless and virtually incorruptible because it managed to account for everything in the sense of everything that exists. The qualification is necessary because dissenters and impure elements were not persuaded and then incorporated into the totality but rather simply eliminated. Despite the ideological justification and the extraordinary practical efforts that were made to erase all traces of the dissenters, ${ }^{125}$ their destruction amounts to a fundamental objection to the claim to totality. Be that as it may. The Nazis also practiced coercion that silenced people by eroding their moral character in a way that made them complicit in the aims of the regime and therefore unable or unlikely to resist it. The infamous example of this practice that Clamence mentions is the story of the German officer who asked an old woman to choose which of her two sons would live and which die. ${ }^{126}$ Whatever other purposes it may have served, the aim of the offer is to seduce the woman into choosing by creating the illusion that a choice in such circumstances is meaningful. Once she does so the game is up and she effectively becomes a willing participant in Nazis atrocities. Whatever objection to the regime she might have offered is then silenced.

The other type of regime that practices this sort of elimination is the modern 
Ph.D. Thesis - R. Srigley McMaster - Religious Studies liberal or bourgeois regime. This type of regime, typified in The Fall by two cities Amsterdam and Paris - does not silence its population through mass killing, as do totalitarian regimes. But Clamence claims that it does have its own "kind of liquidation." ${ }^{127}$ In such regimes the complete rational organization on which it rests slowly nibbles away at every aspect of life - job, family, leisure time - until one is left with nothing but "an immaculate skeleton." Indeed its very structure is rational. No vocations, only jobs, which are created to satisfy the needs of the organization and not the person filling them; the erotic domain of the family become a useful element of social organization; and leisure time - now called "down-time"- little more than empty space that must also be filled up and "organized." 128 No strong loves, no strong hates, nothing to fear or to overcome. One is, as Clamence puts it, "cleaned up," which means that one is spiritually dead and thus ready for participation in the modern bourgeois regime.

The Western regimes of our time have become even better at this form of organization than they were when Camus was writing. The physical and existential slavery required by the regime is likely even more excessive than it was fifty years ago. But the abiding sense of oppression that one would expect to accompany it is rarely felt. The idiom 24/7 is now uttered with great pride and worn as a sort of badge of honour. Yet no one seems to notice how absurd this is. Perhaps the difference is that current bourgeois regimes have finally perfected the art of slavery that Clamence argues is both the most effective and inevitable: slavery "with a smile." ${ }^{\prime 29}$ The slavery itself might still be a form 
Ph.D. Thesis - R. Srigley McMaster - Religious Studies of oppression, but the flow of consumer goods that modernity produces to ameliorate it has grown apace. The reason why the practice has been so effective is that it repeats the Christian teaching on which the society is based. Though you may be deprived of your true or given life by the fall and original sin, grace is always there to console you for its loss and to assure you that your damnation is only temporary. The greater your debt, the greater the grace that saves you from it. Or as Clamence has it in another idiom, such a life is hell, but it is a comfortable, "middle-class hell."130

The purveyors of the bourgeois regime and the life it entails are among the most distasteful modern figures to Clamence, even though in the end he agrees with them and shares their aims. He goes so far as to say that he prefers the criminal to the bourgeois because the latter is actually "more moral."131 At any rate, there is another human type that Clamence discusses in this context as evidence of modernity's desire to silence or eliminate reality - the modern intellectual. Though he initially associates this figure with Paris and thus with bourgeois liberal regimes, in a later discussion he makes it clear that they are also found in totalitarian regimes and that perhaps it is the bourgeois intellectual himself who is totalitarianism's best defender. ${ }^{132}$ In any event, according to Clamence the bourgeois intellectual has two dominant passions - "ideas and fornication." 133 In both instances the aspiration is the same. Ideas in this context mean a preference for the mind's activity over its object and so belie a form of self-love. A similar structure emerges in the case of fornication. Fornication is non-reciprocal sex or sex in which the object of 
Ph.D. Thesis - R. Srigley McMaster - Religious Studies

attention is one's own experience and desire and not the full range of things present or potentially present in the situation. It too is a form of self-love, but this time of the body. The modern intellectual silences reality by forming ideological constructions that negate the real and eliminate the means through which reality most often becomes apparent conversation or dialogue.

You must have noticed that our old Europe at last philosophizes in the right way. We no longer say as in simple times: 'This is the way I think. What are your objections?' We have become lucid. For the dialogue we have substituted the communiqué: 'This is truth,' we say. 'You can discuss it as much as you want; we aren't interested. But in a few years there'll be the police who will show you we are right'. ${ }^{134}$

If we take Clamence's reference to Europe seriously, his point seems to be that a prison cell with a gun to your head and a modern academic conference are not such different places as one might be tempted to think.

Modern ideology is an expression of the same totalitarian impulse that Clamence finds at work in the realm of politics, only this time in the realm of the mind. It is perfectly suited to both types of regimes, but perhaps even more so to liberal ones in which the expression of that aspiration is not as brutal as it is in totalitarian regimes and where ideas and images play a larger role in its efforts to control.

If we examine these various totalitarian ambitions and think about them critically what begins to emerge is an obvious preference for highly ordered and rational structures over looser, more organic patterns of association. That is in politics. If we consider the 
Ph.D. Thesis - R. Srigley McMaster - Religious Studies ambition in relation to human life more broadly understood, it belies a distaste for the actual texture of life and the complexity and ambiguity of all human things. The one thing in particular that it seems most opposed to in this regard is the erotic character of life. Whether it is the bourgeois desire to organize family life and leisure time, or Clamence's non-reciprocal sex, or the intellectual's hatred of real dialogue, or the German officer's attempt to destroy the love in and between mother and child and countless others in the camps, in each case the effort to destroy or silence reality is always directed at a reality understood to be animated by or even to be a play of erotic forces. Thus does the totalitarian inadvertently affirm the very thing he seeks to destroy. Short of murder, his favourite means of accomplishing his goal is by turning those he encounters into petty self-lovers who share his desire but not his ambition or accomplishments. This brings us back to Clamence's own ambition and the darker story behind that ambition that his narrative attempts to obscure.

Clamence obscures the true meaning of his fall and buries his best or truest account of modernity because his confession and his critique are both subordinate to a deeper purpose: to realize within himself the perfection of the modern project as a conscious achievement. His account of modernity is illuminating and compelling as far as it goes, as I have said; however it is also highly misleading. It is misleading precisely because it creates the illusion of having told the whole truth while quietly leaving out essential elements of the account. A close reading of Clamence's narrative reveals that 
Ph.D. Thesis - R. Srigley McMaster - Religious Studies

although he says a good many true things about the nature of modernity, he carefully excludes all questions of meaning that explore the source or cause of modernity's excesses and what distinguishes them from earlier dispensations. Self-love is a human disposition at all times. What makes modernity's version of it different? Why has modern self-love led to the creation of totalitarian regimes and not to the dictatorships and tyrannies of "simpler times"? ${ }^{135}$ What makes modernity so extraordinarily violent, to the point where its violence ceases to serve the even the aims of normal self-love or selfinterest? Despite the apparently candid nature of his narrative, when it comes to answering to these questions Clamence is notably silent.

Clamence's silence is not Camus' own, however. Camus may have buried his meaning in the details and movements of Clamence's narrative, but I would argue that that meaning is clear nonetheless for anyone willing to look for it. It may not be immediately obvious, and it may not be apparent to the casual reader, but there is nothing in principle preventing us from understanding it. Where is it to be found? I think that the devil is in the details. A close reading of Clamence's story, particularly of the subtle changes he introduces at strategic moments in the narrative and the changes of meanings they imply, is where Camus' best interpretation and assessment of the modern project is to be found. I turn now to that reading.

I read The Fall commonsensically, particularly the events surrounding the suicide 
Ph.D. Thesis - R. Srigley McMaster - Religious Studies and Clamence's response to it. And I also take most of what he says about the duplicitous character of his early life in Paris at face value. Prior to his fall Clamence is ceaselessly doing charitable acts. The problem is that he does not do them for charitable reasons, but for selfish ones. What he enjoys is the experience of exaltation that such acts afford him, not their own goodness or the goodness of their outcomes. But Clamence is not aware of this fact, at least not right away. He lives effortlessly and imagines himself a happy and morally admirable human being. Then comes his fall. Though the meaning of the experience requires some interpretation to explain, the event that precipitates it is clear enough. While crossing a bridge one evening after leaving the home of a mistress Clamence finds himself in circumstances that require a genuinely selfless act and discovers that he is completely unequal to the situation. A woman jumps from the Pont Royal into the Seine and Clamence does nothing. The illusion of himself as a significant moral presence in the world is destroyed.

Clamence does his best to forget what happened, so it takes a number of years for the meaning of the experience to have any effect on him. The first sign of its influence occurs in similar circumstances. Clamence is crossing the Pont des Arts when suddenly he hears the sound of laughter as it drifts slowly downstream. ${ }^{136}$ It is an obvious allusion to the original event and clearly troubling for Clamence. The interesting thing about the experience is the character of the laughter and the wider context in which it occurs. Clamence tells his interlocutor that it had been a good day: "a blind man, the reduced 
Ph.D. Thesis - R. Srigley McMaster - Religious Studies sentence I had hoped for, a cordial handclasp from my client, a few liberalities, and in the afternoon, a brilliant improvisation in the company of several friends on the hardheartedness of our governing class and the hypocrisy of our leaders." At the day's end Clamence stands facing the statue of Henry IV and feels as though he dominates the island. "I felt rising within me a vast feeling of power and - I don't know how to express it - of completion, which cheered my heart."137 This is the moment when the laughter first strikes. Though Clamence is clearly taken aback by the experience, he makes sure to tell us that there was nothing mysterious or sinister about the laugh; "it was a good, hearty, almost friendly laugh, which re-established the proper proportions."138

It is a wonderfully theatrical moment and we can imagine the scene perfectly: there is Clamence, perched on the Pont des Arts and gazing out over the Île de la Cité, imagining himself a cross between the King of France and Saint Augustine. ${ }^{139}$ Suddenly peels of laughter break out behind him as he stands there completely non-plussed. This is funny. We do not know who or what the laughter is. Is it the gods, or is it Clamence's conscience? Either seems plausible. But it does not really matter. What is important here is what the laughter means and what it teaches Clamence about his life and what he must do.

The comedy of a situation is a good indication of its meaning. If I were permitted to do something that is not funny and explain a joke, I would say that the humour of the situation lies in the disproportion between Clamence's opinion of himself and who he 
Ph.D. Thesis - R. Srigley McMaster - Religious Studies really is. Clamence himself says as much when describing the character of the laughter. He tells us that it "re-established the proper proportions." 140 The laughter discourages the excesses to which Clamence's self-love leads him and encourages him to take the proper measure of things. But it does so without condemnation and without any compulsion other that its own intrinsic content or meaning.

In a sense the laughter is Clamence's fall, and each time it occurs it has this character. At the end of chapter four, after doing his best to disabuse others of the good opinion they hold of him and before he plunges into debauchery, Clamence hears it once again. But here also there is nothing ominous or horrifying about the experience. Indeed Clamence even finds the laughter "benevolent." "Until then, the laughter continued to drift my way, without my random efforts succeeding in divesting it of its benevolent, almost tender quality that hurt me."141 It is precisely the benevolent quality of the laughter that troubles Clamence most along with its playful attempt to "re-establish the proper proportions." Why? These things genuinely challenge Clamence's self-love and gently encourage him to do better; and they leave little room for him to evade the criticism through the easy counter-charges of false moralizing or competing self-interest to which those who seek to correct us are often open. The laughter demands nothing for itself and does no harm. It merely tells Clamence the truth about himself without condemnation and with the full range of possible responses left completely open to him, including the one he ultimately settles on. The situation becomes "sinister" only after Clamence finally turns 
Ph.D. Thesis - R. Srigley McMaster - Religious Studies his back on the laughter's influence altogether and takes matters into his own hands. ${ }^{142}$ Then the story becomes dark indeed.

There are other moments in the narrative during which Clamence has experiences that are comparable to those associated with the laughter. His relationship to death is one of them, as is his account of the nature of life's seriousness. ${ }^{143}$ In both cases the insight he derives from the experience is the same. The excesses of his self-love are diminished and his judgement begins to improve as a consequence. This can be seen in the way his assessment of himself and others gains a sense of measure or proportion. He does not fear death itself but dying "without having confessed all [his] lies."144 In other words what troubles him is not the termination of his existence but its moral corruption. This is essentially Socrates' assertion in the Gorgias that a "true man...must reject living any amount of time whatsoever, and must not be a lover of life." 145 Compared to the "greatest evil" - that he become "degenerate and maimed in his soul" - death is as nothing. ${ }^{146}$ It is also consistent with the insight of the Phaedo in which Socrates teaches his companions that wisdom or philosophy is the art of "preparing [oneself] for dying and death."147 Clamence puts it this way: "The day I was alerted I became lucid; I received all the wounds at the same time and lost all my strength all at once. The whole universe then began to laugh at me. That is what no man (except those who are not really alive - in other words, wise men) can endure."148 Though he states the matter negatively it is the same insight. The wise are dead because they do not fear the laughter but embrace it and 
Ph.D. Thesis - R. Srigley McMaster - Religious Studies follow what it teaches. They are dead to the petty vanities that fuel most of human life and death itself is of no importance to them when compared to the care of their own soul and those of others.

Clamence's remarks about life's seriousness reveal a similarly renewed sense of proportion and easing of the demands of self-love as do his insights about death. And they too bear a remarkable similarity to insights found in the Platonic dialogues, in this case the Republic and the Laws. Clamence prepares his interlocutor for the shock of what he will say by telling him it is "wretched" or immoral. There is heavy irony here and an indication of the character of Clamence's audience, because in fact the remark is neither wretched nor immoral but extraordinarily modest and humane. The wretchedness is apparently only in the ears of those who will hear it. At any rate, what Clamence says is this:

I have never been really able to believe that human affairs were serious matters. I had no idea where the serious might lie, except that it was not in all this that I saw around me - which seemed to me merely an amusing game, or tiresome. ${ }^{149}$

This is the same insight that Socrates offers in book ten of the Republic, and which is repeated by the Athenian Stranger in book seven of the Laws. In the Republic Socrates encourages Glaucon to bear misfortune well by teaching him that the good and bad in such things are not clear and that "nor are any of the human things worthy of great seriousness." 150 In the Laws the Athenian Stranger teaches Kleinias and Megillus that one must do what one can to prepare for "this voyage of existence" that is life, but he adds a 
Ph.D. Thesis - R. Srigley McMaster - Religious Studies proviso that tries to capture the complexity of the situation: "Of course, the affairs of human beings are not worthy of great seriousness; yet it is necessary to be serious about them" in some way. ${ }^{151}$ The Stranger illustrates the meaning of his account of seriousness by describing human beings as playthings of the gods and by encouraging Kleinias and Megillus to play the "noblest possible games" in response - "sacrificing, singing, and dancing." 152 In The Fall Clamence follows up his initial remark with the example of two places in the world where he feels "innocent" and where human affairs are treated with a fitting seriousness - the theatre and the stadium. ${ }^{153}$ Clamence's notion of serious play is perfectly in accord with Plato's account of these things. And what else are the theatre and the stadium but places where one sacrifices, sings, and dances most beautifully?

The similarities between Clamence's account and those of Socrates and the Athenian Stranger are too close to be accidental. I think Camus put them there intentionally in order to elucidate the nature of Clamence's fall and the manner in which he ultimately departs from the insight it affords him. ${ }^{154}$ To recognize that human affairs are not worthy of great seriousness is to mortify one's self-love. The tendency of self-love is precisely to insist that each of its activities or experiences is of everlasting moment. We all know that this tendency is untrue or unfaithful to the way the world is ordered and that those who insist on its truth have somehow lost their sense of that order. Clamence knows this too as Camus's incorporation of the platonic analysis into his account indicates. But that analysis is likely also intended to suggest a further insight. Despite appearances to the 
Ph.D. Thesis - R. Srigley McMaster - Religious Studies contrary, those who insist on the absolute seriousness of human affairs are actually guilty of a form of impiety because only the god "is worthy of complete, blessed seriousness."155 This additional insight is consistent with the irony of Clamence's introduction to the discussion and it raises serious questions about the piety of Christian and modern apocalyptic aspirations. ${ }^{156}$

The nature of Clamence's fall as it is revealed through his experience of the laughter and through his insights about life and death raises an important interpretative problem. The problem relates to the manner in which his narrative changes in chapters five and six and the means by which he seeks finally to overcome his fall. To state the problem simply: the solutions Clamence proposes in these later chapters - debauchery and the judge-penitent - are neither proportionate to, nor called for by, his fall as he initially describes it. And there is a similar disproportion or contradiction in the descriptions of his fallen state itself. Toward the end of chapter five Clamence introduces the image of the "little-ease," a medieval torture device, as the best way to depict his unredeemed or fallen state. This image marks a significant shift in the content of the analysis and a notable change of tone. According to the description the little-ease is a condition that is both horrifying and impossible. Not so of Clamence's fallen condition as he initially describes it. Earlier the feeling of impossibility is denied explicitly by remarks that make it amply clear that a simple change of life is both possible and desirable. ${ }^{157}$ And 
Ph.D. Thesis - R. Srigley McMaster - Religious Studies there is no horror associated with the experience whatsoever, only the normal shame of a human being who has become aware of certain ignoble aspects of his character. What this means is that the little-ease is not an empirical description but a "hypothesis" or interpretation. ${ }^{158}$ Clamence settles on it only after considering and rejecting other hypotheses or interpretations, the most important of which is the one I have outlined above and which actually has some claim to primacy of place because of its repeated appearance throughout the analysis and its prominence in the description of the event itself. But if the account is unfaithful to the experience, then why does Clamence employ it? Why does he change the account so as to make an eminently superable situation seem insuperable and horrific? The most important feature of The Fall's critique of modernity and Christianity is contained in the answer to that question. To formulate it we must examine more carefully and slowly the changes that occur in Clamence's narrative over the course of chapters four, five, and six.

Chapter four describes Clamence's life in the days and months immediately following his fall. It is filled with the normal confusions and ambiguities one would expect from a person in such circumstances. The best measure of Clamence's moral and intellectual health during this period and indeed during any other is the extent to which his descriptions of his condition match the content of the insight he gains from the experience of the laughter. The content of that experience? A judgement regarding his self-love but without any condemnation or threat of reprisal in it. The descriptions even 
Ph.D. Thesis - R. Srigley McMaster - Religious Studies suggest an kind of invitation to change his ways and an assurance that he is entirely free to do so. But by the end of chapter four Clamence has chosen to abandon the lessons of the laughter and to respond to his crisis of conscience in a very different way. The reason he does so is obvious: the laughter requires him to abandon his self-love as a condition of the healing it offers and he is unwilling to do so. He then sets about finding a way to silence the laughter without heeding its counsel; and he will distort the meaning of what it teaches him if need be in order to accomplish this task. His earlier "random efforts" did not succeed in "divesting it of its benevolent, almost tender quality."159 But his subsequent efforts will. As Clamence says in the final pages of the book,

I permit myself everything again, and without the laughter this time. I haven't changed my way of life; I continue to love myself and to make use of others. Only, the confession of my crimes allows me to begin again lighter of heart and to taste a double enjoyment, first of my nature and secondly of a charming repentance. ${ }^{160}$

The "sinister moment" that occurs at the end of chapter four and that hangs over the remaining analysis like brooding dark clouds is the result of these efforts and not a natural consequence of his fall. ${ }^{161}$

At the beginning of chapter five Clamence is returning from a trip to the "soggy hell" of the Zuider Zee, which he likens to "everlasting nothingness made visible." ${ }^{162}$ As he does so the structure of the narrative is interrupted briefly. In the final sentence of chapter four Clamence announces that he must now discuss debauchery and the littleease. ${ }^{163}$ But before doing so he pauses to describe his experience of travel in the Greek 
Ph.D. Thesis - R. Srigley McMaster - Religious Studies archipelago and to compare it to what he discovers in Amsterdam. As they leave the island of Marken Clamence assures his interlocutor that they are moving at "top speed." Yet they cannot gauge their progress because the bareness of the landscape and the fog that envelopes them obscures all landmarks by which they might take their bearings. "We are making progress and yet nothing is changing."164 This is an image of modern developmental or progressivist accounts of history of the type we find in Hegel and Marx but also in the positivistic historiography favoured in the West. In modernity things and events move rapidly because developmental histories are teleological and because the modern picture of the physical universe tends to identify speed and simultaneity or completion. ${ }^{165}$ This is our apocalypse and it has become a rather persistent idea in the West. It is arguable that in our time all that is left of the content of the revolutionary movements of the late nineteenth and early twentieth centuries is this addiction to speed. ${ }^{166}$ Nonetheless Clamence teaches us that historical progress of any kind provides only an illusion of meaning and that when events are judged properly the nature of that illusion becomes transparent. That is what he means when he says that on the Zuider Zee "it's not navigation" one practices "but dreaming." 167 Meaning and progress are not attributes of history understood providentially but indices of things in their cultivation or corruption. Or to use another formula, there is meaning in history but no meaning of history. ${ }^{168}$ The difference between the two is the difference between real navigation and dreaming or fantasy. 
Ph.D. Thesis - R. Srigley McMaster - Religious Studies

Moderns are not the only ones to endorse this type of historical progressivism.

Clamence implicates Christianity in the practice through his reference to the Zuider Zee as a "dead sea." 169 The Dead Sea does not figure prominently in the biblical narrative but it immediately suggests a relationship to both Christianity and ancient Israel that is further confirmed by subsequent aspects of the analysis. ${ }^{170}$ Christianity's providential history has the same basic structure as those found in modernity and encourages the same sorts of neglect. The neglect is a direct consequence of the providentialism and of the self-love that motivates it. Providential histories satisfy the demands of self-love because they order all events, even the most tragic and incongruous among them, in a way that confirms the truth of the account and guarantees its supremacy. The neglect follows from this. The second order of meaning imposed by providential histories can be acted upon and even have a significant influence on people and events but it cannot provide meaning or answer to the demands of real events. But since real events do not thereby disappear but continue to exert their pressure, they must be either ignored or carefully concealed in order to neutralize their presence and sustain the second order meaning. The consequences of these histories are therefore not negligible. As the monumental ambitions and achievements of modern progressivism increasingly impose themselves on the order of life a nagging sense of emptiness grows apace. Clamence's notion of "universal obliteration" captures the nature of the experience extremely well.

After describing the dream world of Christian and modern providentialism 
Ph.D. Thesis - R. Srigley McMaster - Religious Studies

Clamence becomes lyrical and pauses to recount a memory of his travels in the Greek archipelago. In Greece he has "the contrary feeling" to the one he experiences in the Zuider Zee. His account is worth citing in full.

Constantly new islands would appear on the horizon. Their treeless backbone marked the limit of the sky and their rocky shore contrasted sharply with the sea. No confusion possible; in the sharp light everything was a landmark. And from one island to another, ceaselessly on our little boat, which was nevertheless dawdling, I felt as if we were scudding along, night and day, on the crest of the short, cool waves in a race full of spray and laughter. Since then, Greece drifts somewhere within me, on the edge of my memory, tirelessly... ${ }^{17}$

Apart from the barely restrained delight and the quiet lament that this memory provokes in Clamence, it offers a starkly different image of both history and progress from the Christian and modern accounts that he depicts by means of his journey through the Zuider Zee. Though the Greeks move far more slowly than their Christian and modern counterparts, the progress they make is real and not a dream. It is real because its ends are achievable and because they are measured against real things - the land, sea, and sky of the image. The abiding sense of clarity and moral soundness that the image evokes is also important. One of the main consequences of Christian and modern providentialism is a certain moral confusion that today goes by the name of dialectics. The Nazi murder and deportation of seventy-five thousand Jews may seem horrifying, but if one considers it in relationship to God or history's plan it might also be good. Any form of historicism and indeed any aspiration to totality whatsoever will corrupt moral judgement and the habits of virtue because it requires this type of dialectical thinking as a condition of its 
Ph.D. Thesis - R. Srigley McMaster - Religious Studies existence. Hence the importance of Clamence's apparently simple insistence that for the Greeks the sky is the sky and the land is the land and the sea is the sea and two mature men walking hand in hand is a expression of friendship and enjoyment, not of "filth."172 What the Greeks teach and the insight Clamence gains from his fall are matched throughout the book. In order to leave no doubt about their connection Camus even has the laughter make a cameo during Clamence's analysis of the Greeks. Here too it retains its playful and benevolent character and its encouragement of proportion or measure. ${ }^{173}$ But there is something more in addition. While among the Greeks the laughter ceases for a moment to judge and instead expresses something close to guileless delight or even harmony. ${ }^{174}$ The reason for the change is clear. For Clamence the Greeks are not duplicitous in the manner of Christians and moderns and therefore the laughter abates when he lives as they do. This does not mean that they are innocent or without self-love; nor that the problem with Christianity and modernity is merely one of hypocrisy. Both are constant features of human life and therefore possible at all times. Rather the change suggests a more fundamental kind of dishonesty in the latter two traditions that discourages them from facing their baser inclinations and desires honestly and that forces them to construct images of deliverance or salvation in compensation that more often than not provide both opportunity and alibi for the very self-love they claim to overcome.

The coincidence between Clamence's fall and the teachings of the Greeks yields an important insight into the structure of The Fall and the nature of Camus' critical 
Ph.D. Thesis - R. Srigley McMaster - Religious Studies analysis of Christianity and modernity. Clamence's pre-fall life is modernity writ small. The relationship between the two deprives modernity of its good conscience and demonstrates that behind the facade of its moral discourse lies a much more dangerous ambition. Its true animating principle is a self-love that has been freed from any restraint and has therefore lost all sense of proportion. What affords him this insight and gives him the opportunity to escape the modern ambition is his fall - that is to say, the Greeks. The Greeks supply the critical content of the experience and point the way out of the crisis. ${ }^{175}$ Here as elsewhere in Camus' books they do so in the usual way: by encouraging measure and a sober assessment of the human condition, by preferring virtue to the emotional excesses of faith, ${ }^{176}$ and by reminding us about the tragic in existence and discouraging apocalyptic hopes. But in addition to these teachings The Fall contributes a further insight about the Greeks and eros through an analysis of the ways in which both have been silenced by the advent of the Christian religion and its continuation in modernity. Clamence is a modern who is offered a way out of the modern world. The price (and the prize) of that escape is a restoration of eros together with the Greeks. Ultimately he decides against both. With the Greeks abandoned he turns instead to a world in which he is able to maintain the appearance of love without the price of its achievement while simultaneously encouraging his self-love to flourish. Chapters five and six describe that change of meaning and identify the world to which it leads: Christianity.

The transmogrification of Clamence's fall from a moment of moral health into the 
Ph.D. Thesis - R. Srigley McMaster - Religious Studies horror of the little-ease is a depiction of the historical destruction of Greek measure in favour of Christian excess and the deformation of eros into vice or self-love. In Beyond Good and Evil Nietzsche writes that "Christianity gave Eros poison to drink: he did not die of it but degenerated - into a vice."177 In The Fall Camus builds on Nietzsche's insight and deepens it by explaining the mechanism through which Christianity accomplishes this aim. And the text offers another image that sheds light on the meaning of this change. Clamence claims that the Zuider Zee is like Dante's limbo - a sort of "vestibule of Hell" reserved for "neutral angels in the quarrel between God and Satan."178 We, too, "are in that vestibule," he tells us. ${ }^{179}$ But why only there? Why such a mediocre place? "Not enough cynicism and not enough virtue. We lack the energy of evil as well as the energy of good." ${ }^{\prime 180}$ But there are those who do not lack this energy, and who are not content with the comforts of a middle-class hell. Clamence is one of them. In chapters five and six of The Fall he leads us from the mediocre hell of the Zuider Zee toward its "last circle," where life and its crimes become "denser, darker." 181 I would argue that the concurrence of these images and changes is not accidental.

The little-ease is an image of the Christian teaching about original sin and our fallen condition and its function in Clamence's narrative is similar to the one it has in the Christian account. It sets the stage for an apocalyptic redemption in which the effects of the fall will be overcome and the world will be restored to its proper order. Of course 
Ph.D. Thesis - R. Srigley McMaster - Religious Studies Clamence's reworking of the story is frankly irreligious and anti-Christian. But this makes no difference regarding the content of the analysis. The meaning or human disposition it reveals remains the same in both cases. "On dead innocence the judges swarm, the judges of all species, those of Christ and those of the Antichrist, who are the same anyway, reconciled in the little-ease."182 Despite their phenomenal differences the Christian and modern accounts are the same thing. Or in a slightly different formulation, modernity continues Christianity and sheds light on its ambition. In The Fall Clamence's symbol of the little-ease is the place where the two teachings converge most clearly.

There are several aspects of Clamence's account that require explanation. The little-ease is a medieval torture device. Already this image reveals some of the content of Camus' critical analysis. According to the Christian teaching original sin precipitated a condition from which all human beings suffer though they were not responsible for the act of disobedience that initially caused that condition. They are guilty, but not of the original $\sin .^{183}$ Nevertheless they must endure its consequences and are destined to repeat it in the conduct of their lives. Several things follow from the teaching regarding its account of the human condition. The notion of an originally perfect nature from which human beings have somehow fallen implies that life as we now experience it is unnatural. This is further complicated by the Christian tendency to refer to those outside its sphere of influence or who do not accept its teaching as natural human beings. Natural in this sense is opposed to supernatural, as in God's supernature and the supernatural revelation 
Ph.D. Thesis - R. Srigley McMaster - Religious Studies of Jesus that lies at the heart of Christianity. If we put this together with the unnaturalness introduced by the fall, we have the strange notion that nature is unnatural. Stated in this way the formulation captures the ambiguity of the teaching and helps to explain the odd psychological states it encourages. In their immediacy all desires and experiences are perceived as natural or normal in the sense of given. Yet under the influence of Christian doctrine we also struggle with the counter impression that they are somehow unnatural or abnormal. This is particularly true of sexual desires. It is no accident that in Genesis the advent of sexual awareness and the experience of shame coincide. Adam and Eve partake of the fruit and immediately "the eyes of them both were opened, and they knew that they were naked." 184 For the Greeks sexual desire is simply a given in human life. They would agree with others that it is wise to think deeply about its best satisfaction. But they would find the idea that the desire itself is shameful to be strangely unnatural.

The unnaturalness of the human condition inherent in the doctrine of original sin is exacerbated by the further claim that that condition is also inescapable. This is a central Christian teaching. Redemption is impossible without divine grace. Human effort alone is insufficient. Even our virtues are not enough because they too belie the limitations of our fallen nature, principally the pride of human self-sufficiency. ${ }^{185} \mathrm{Be}$ that as it may, this unnaturalness tends to denigrate all human experiences, particularly the baser ones. But when that denigration is coupled with the notion that our condition is insuperable, the experience begins to move toward the demonic. ${ }^{186}$ The world seems like a trap or prison 
Ph.D. Thesis - R. Srigley McMaster - Religious Studies from which one cannot escape and life begins to acquire an aura of impossibility and even cruelty because one is denied things one needs by nature in order to live. ${ }^{187}$

According to the Christian teaching our awareness of the human condition cannot achieve this level of clarity unaided. The corruption introduced by the fall is so complete that a full understanding of the nature of its character is inaccessible to natural human understanding. ${ }^{188}$ Concretely what this means is that the one who accepts the account has a sense that something is deeply wrong both with himself and with the world but is incapable of forming any clear idea of its origin or even determining its content. To use a formulation from The Fall, we could say with Clamence that "the keenest of human torments is to be judged without a law. Yet we are in that torment."189 What else is Clamence's remark but an expression of this feature of the doctrine of original sin? You are guilty in some fundamental way, but you do not know of what. And whatever you do to shake or overcome this sense of guilt only serves to make it more intractable. One of the best modern expressions of the experience is Kafka's novel The Castle. Certain passages from Beckett's Waiting for Godot also capture its nature. Paul's lament in Romans 7:19-25 is an older expression of the problem. However in Paul's case the assurance of order provided by the law affords a consolation missing from these later accounts, even though that law is in the process of being overturned. At all events, the experience is the foundation on which is constructed the final feature of the Christian narrative that we must now discuss. 
Ph.D. Thesis - R. Srigley McMaster - Religious Studies

The apocalyptic ambitions of the Christian religion are the inevitable consequence of its teaching about the fall and original sin. If the world is radically fallen or evil then it stands to reason that it must be restored. The excesses of the fall are mirrored in the excesses of redemption. Earthly life may be a nightmare, but it will be compensated for by an undreamed of perfection. The two elements form a coherent narrative that contains just enough of the content of real life to seem persuasive. The desire to move from a worse condition to a better one is the stuff of life. But determining which is which is usually a difficult business and the truly wise know to tread carefully and thoughtfully here. ${ }^{190}$ The Christian account simplifies and distorts this structure at the same time that it employs it for its own purpose. Achieving the emotional or intellectual state that guarantees contact with the eternal or the "other world"191 and provides hope of redemption is simply not the same thing as the acquisition of virtue and the difficult task of choosing between the better and worse in this life. Moreover the difficulties associated with the achievement of these states - the trials of faith or the dark night of the soul - are either poor copies or inconsequential distractions in comparison to the real business of life and the acquiring of moral courage. We are so accustomed to thinking of the former sorts of experience as the best examples of moral seriousness that we believe the evaluation should be the other way around. But it is not. The Christian aspirations merely mimic the Greek virtues of wisdom and prudence while emptying them of their content.

All of these structures and ambitions are repeated in Clamence's narrative and 
Ph.D. Thesis - R. Srigley McMaster - Religious Studies with the same intent. But with this difference. Camus puts them there in order to illuminate critically the true nature of the Christian account and to explain its complicity in the modern project. Clamence's fall affords him real insight into the nature of his selflove and gives him a chance to change his ways. It is his best moment, and Camus structures the analysis to make it clear that it is also a Greek one. But Clamence is not willing to do as his conscience dictates. Instead of acting on his new insight he seeks to return to his old ways. But the thing that stands in his way is precisely this insight into the character of his former life and the self-love that guided it. How to get rid of that insight and the judgement that accompanies it while simultaneously indulging his self-love? Clamence's solution to that problem is contained in his account of the little-ease and his role as judge-penitent. Both mark a fundamental departure form the teachings of the Greeks.

Clamence begins by exaggerating the nature of his condition as revealed through his fall. Instead of the benevolent judgement and gentle irony of the laughter we have the little-ease - a torture device designed not to punish a proven offense but to create the feeling of having committed one, along with the accompanying sense of guilt. What better image of the Christian teaching about original sin than this? "Every day through the unchanging restriction that stiffened his body, the condemned man learned that he was guilty and that innocence consists in stretching joyously. Can you imagine in that cell a frequenter of summits and upper decks? What? One could live in those cells and still be 
Ph.D. Thesis - R. Srigley McMaster - Religious Studies innocent?"192 The critical element of Camus' analysis is apparent in the hypothetical character of the construction. In response to his own question Clamence replies: "Improbable! Highly improbable! Or else my reasoning would collapse. That innocence should be reduced to living hunchbacked - I refuse to entertain for a second such a hypothesis. ${ }^{1193}$ But this is the point. It is possible to retain one's innocence in such circumstances, so his reasoning collapses. There are countless examples of those who have resisted precisely this type of coercion. It might not be easy, but it is eminently possible. And this is true intellectually and spiritually as much as it is physically. One need not be fooled by Clamence's sophistry or by Christian dialectics. The resources necessary to see through these practices are given to all human beings. This has nothing to do with intelligence or highly refined intellectual abilities. Indeed intellectuals are among Clamence's favorite subjects. They may take longer to convince, but in the end he gets as fine a confession out of them as he does out of those who are far more sentimental in nature. ${ }^{194}$ The possibility of resistance is given to all human beings by virtue of their basic grip on reality and their participation in all of its dimensions. A stonecutter like Socrates or an old farmer/poet like Hesiod would not be taken in by Clamence's confidence game for a moment.

The shift from the fall to the little-ease is the first indication of the odd manner in which Clamence tries to solve his problem by reversing the normal order of things and traveling "the road in the opposite direction." 195 This tactic itself is a Christian 
Ph.D. Thesis - R. Srigley McMaster - Religious Studies innovation. ${ }^{196}$ Instead of a measured shame and a honest attempt to change, he prefers measureless guilt without absolution and without the possibility of improvement. ${ }^{197}$ In other words, a worse condition, not a better one. But why? The answer lies in the original Christian doctrine on which the account is modeled. Clamence has no intention of remaining in his unredeemed state anymore than Christians believe that the fall is insuperable. Being the worst of the worst merely suits his purpose, which is not by any means to remain the worst in this sense. ${ }^{198}$ The account is not a description of the human condition but a construction with two related moments. The only ones for whom it might be description are the ones who created it - the Jews - and for them it meant something quite different than what it means in Christian theology. ${ }^{199}$ A public confession of being the worst creates an appearance of piety and remorse but without their substance. This illusion of piety is the cover beneath which Clamence's self-love works. The act of repentance quiets the laughter without diminishing his self-love because both are satisfied by the same act. It also lends credibility to the otherwise unnatural idea of an apocalyptic fulfillment in which the evil it has created will be eradicated and human immortality achieved. Immortality is perhaps the highest ambition of unbridled self-love. The minute Clamence abandons the influence of the laughter and the teachings of the Greeks his desire for immortality reasserts itself once again. This is not an accident. His analysis makes it clear that debauchery is not merely a means by which to satisfy that ambition, but the ambition itself. ${ }^{200}$ "In a sense, I had always lived in debauchery, never having 
Ph.D. Thesis - R. Srigley McMaster - Religious Studies ceased wanting to be immortal."201 If debauchery is a prodigious amount of lust or selflove, then the desire for immortality is its most extreme expression. That is Camus' insight, and it goes some way to explaining the orgiastic character of a book like Revelation and the absence of that character from an afterlife story like, say, the one we find in the Republic. ${ }^{202}$ In the former text human immortality is taken as given and the details are mapped out accordingly; in the latter it is at most a possibility and in any case it adds nothing new to the analysis offered in the text itself which is constructed without reference to such considerations.

The aim of the shift from the laughter to the little-ease is to make us easier prey for Clamence and to satisfy his ambition. Playing on people's bad conscience and their sense of futility is the manner in which he establishes his own superiority and secures their subordination. ${ }^{203}$ But to maintain these achievements he must make the experience perpetual. How to do that? By creating the impression that the little-ease is inescapable. That impression is of course encouraged by the image itself. But there is another way in which Clamence changes the account of his fall in order to confirm it and it is here that the comparisons between Christianity and modernity become more illuminating and compelling.

The particular aspect of the account that changes is Clamence's analysis of human duplicity. Toward the end of the book he declares that he has "accepted human duplicity instead of being upset about it."204 The declaration implies that he has not abandoned the 
Ph.D. Thesis - R. Srigley McMaster - Religious Studies lesson of the laughter but rather has learned how to live with it. But is this so? The laughter teaches Clamence that his selfless acts are in fact nothing more than self-love in disguise. But that duplicity is not the duplicity of human nature revealed through the laughter. Good deeds done for selfish reasons are selfish deeds, simply. They constitute only one pole of that duplicity, the pole of self-love. The other pole is not named in The Fall, it is true. But it is depicted in the several different ways - through the laughter itself, through its identification with the Greeks, and through Clamence's account of life and death. In each of these cases that love involves real erotic attachments to other people and things and a sense of proportion in one's judgements about oneself and others. That is the other pole of human duplicity, and it is the one that the laugher encourages him to pursue and cultivate.

All of Clamence's explicit statements about the nature of human duplicity pervert the account taught to him by the experience of the laughter. They do so by attempting to pass off the duplicity of his self-love as the duplicity of human nature per se, thereby eliminating any meaningful notion of proper love. Accepting or not accepting human duplicity changes nothing for Clamence. The only difference between his pre-fall and post-fall lives is the additional layer of intellectual sophistication required by his greater awareness of his condition. But substantially nothing changes. As Clamence himself says, I permit myself everything again, and without the laughter this time. I haven't changed my way of life; I continue to love myself and to make use of others. Only, the confession of my crimes allows me to begin again lighter in heart and to 
Ph.D. Thesis - R. Srigley McMaster - Religious Studies taste a double enjoyment, first of my nature and secondly of a charming repentance. ${ }^{205}$

The plausibility of the account stems from its reduction of proper love to selflove. Appearances to the contrary notwithstanding, for Clamence human nature includes no genuine love of others, only self-love or self-interest. When he says that human beings have two faces and that they "can't love without self-love,"206 self-love quietly assumes primacy of place and the two faces merge into one. The proper name for a love that requires self-love for its existence is self-love. And the same is true of similar formulations that Clamence uses elsewhere: "modesty helped me to shine, humility to conquer, and virtue to oppress. I used to wage war by peaceful means and eventually used to achieve, through disinterested means, everything I desired." ${ }^{207}$ A virtue that seeks to conquer is not virtue but vice, just as a modesty that feeds the ego is not modesty but pride. Clamence uses such formulations because they convey the nature of his duplicity and are effective techniques for seducing others who are guilty of the same. ${ }^{208}$ But he also knows not to push the analysis too far lest he betray his real ambition. After confessing to this same type of duplicity a second time, he hesitates: "I stop there, for too great a symmetry would upset my argument."209 What symmetry? And why would it upset his argument? Symmetry in this context is simply another word for his reduction of virtue to vice or love to self-love. Were Clamence to make the artificial character of that reduction clear his argument would be undone. The little-ease is simply self-love become the 
Ph.D. Thesis - R. Srigley McMaster - Religious Studies permanent and inescapable nature of human life. But since human nature does not change we still suffer the shame of our actions. But no matter. There is no danger that we might overcome that shame because the account denies that any genuine act of love is possible. ${ }^{210}$ So we are judged without law and without order and without the possibility of improvement. According to Clamence this is the "keenest of human torments" 211 ; it is also one in which he seeks to imprison all human beings in order to serve his own ambition.

Clamence's solution of the judge-penitent helps to sustain the impression created by the little-ease that he is struggling with real human duplicity while at the same time allowing him to satisfy his apocalyptic ambition to bring all such duplicity to an end. I will discuss the former aspect of the solution first, the latter second.

There is a simple way to bring out the problematic character of the judge-penitent symbol and to indicate the manner in which it precludes human duplicity rather than expressing it faithfully. One only need ask which term of the symbol expresses which side of the duplicity. Is the judge a manifestation of the proper order of love? Or is it the other way around? Is the remorse of the penitent the right expression of love and the moralism of the judge its antithesis? We can leave aside for the moment the fact that Clamence himself plays both roles, which is already a corruption. A penitent seeks the forgiveness of the one he has harmed. He cannot forgive himself. And a judge's role requires that his own life be free of similar failings if his judgement is to have both 
Ph.D. Thesis - R. Srigley McMaster - Religious Studies credibility and soundness. The real problem with the formulation is that both terms of the symbol are expressions of Clamence's self-love. In other words it is a set-up. Neither term expresses the true nature of human dividedness. Given the structures of the littleease, Clamence's judgements are as inordinate and false as are his confessions. They are intended to crush his listeners and enhance his own sense of superiority, not to clarify the machinations of self-love or to restore human relations. ${ }^{212}$ And the same is true of his repentance. Clamence repents in accordance with the demands of the little-ease. But he does not do so in order that he or anyone else might change their ways but to ensure that those demands remain permanent while simultaneously creating the sense that he has satisfied them. Clamence does not change his way of life at all and he extends the same courtesy to others. ${ }^{213}$ His role as judge-penitent therefore guarantees the continuation of his own self-love and encourages the same in others as a means of controlling them. It is a corruption of human nature and not an expression of its struggles.

The apocalyptic character of Clamence's ambition is what illuminates most clearly his relationship to, and the nature of, Christianity and modernity. The need for an apocalypse rests on the assumption that life is a problem that requires a solution. But not just any solution. The degradation to which the apocalypse is an answer is complete and therefore requires a solution that is both complete and unprecedented. One twentiethcentury name for this aspiration is "the final solution." It is a sectarian notion that denotes the pursuit of a new arrangement of human affairs to be brought about by the elimination 
Ph.D. Thesis - R. Srigley McMaster - Religious Studies of whomever or whatever is deemed the source of humanity's age-old troubles. For the Nazis it was the Jews and any other non-Aryan influence; for the Soviets the bourgeois and capital; for a modern Western liberal anything that stands in the way of the technological pursuit of perfection. ${ }^{214}$ No matter how well the apocalyptic thinker manages to mask this outcome by attempting to write his demands and aspirations into the very fabric of human life, this structure remains a permanent feature of all apocalyptic accounts. ${ }^{215}$ The apocalypse ushers in a new order that is both total and qualitatively different from anything that preceded it. Another twentieth century name for this aspiration is the end of history. ${ }^{216}$

Clamence knows that the madness of modernity is the consequence of such apocalyptic ambitions. This does not mean he will abandon his own apocalyptic aspirations, however. To the contrary, he believes he has discovered the apocalyptic solution to end all apocalyptic solutions. Nonetheless, his judgement about the nature of the madness is illuminating.

Deprived of their natural curb, the judges, loosed at random, are racing through their job. Hence we try to go faster than they, don't we? And it's a real madhouse. Prophets and quacks multiply; they hasten to get there with a good law or a flawless organization before the world is deserted. Fortunately, I arrived! I am the end and the beginning; I announce the law. In short, I am a judge-penitent. ${ }^{217}$

This is a compelling description of the modern world. The violence of modern apocalyptic creeds and movements has come close to making the world a desert. ${ }^{218}$ But this has not diminished in the least modernity's apocalyptic ambitions. One prophet or 
Ph.D. Thesis - R. Srigley McMaster - Religious Studies quack is outbid by another in a frantic and seemingly inexhaustible attempt to establish the perfect kingdom before everyone alive is dead and there remain nothing but ruins to rule over. ${ }^{219}$ The image captures the strange persistence of these apocalyptic ambitions in modernity. Nothing grabs our attention or seems compelling anymore unless it promises some kind of revolution or a brand new system of thought that will finally shake down the mystery of the universe. And it seems that no matter how many times this ambition is disappointed we somehow find a way to sustain the illusion that perfection is just around the corner and thus to keep the apocalyptic engine running. Clamence is a case in point. The description of the modern world is his own so he understands the madness of its apocalyptic desires. Yet it does not affect him. He too has a final solution, so he is as mad as the rest of them.

According to The Fall the madness of the apocalyptic ambition lies in its attempt to escape the structure of reality as it is revealed through Clamence's fall and his experience of the laughter. That reality has many dimensions or features, but it is best understood as a play of erotic forces. One either gains or loses one's humanity depending on the character of one's participation in that play of forces. Unlike both Christian and modern apocalyptic accounts, this one takes the struggles of our divided nature seriously. It also identifies the real source of the modern and indeed any form of resistence to participation in that reality. Behind such apocalyptic ambition is a self-love that has grown to extraordinary proportions and that refuses to accept its limited place in the order 
Ph.D. Thesis - R. Srigley McMaster - Religious Studies

of the cosmos. It is not, as Camus sometimes suggests in The Rebel, a noble or even natural desire for salvation.

Camus creates Clamence in order to illuminate the nature of modernity and to explain the complicity of Christianity in its project. Much of that analysis we have explored in the preceding pages. But one of its most fundamental features still needs to be examined. In The Rebel Camus tackles the same problem, but the analysis there remains incomplete because it is hampered by assumptions and methodological restrictions that prevent him from examining his subject fully and honestly. In The Fall those assumptions and restrictions are absent. Here Camus no longer labours under the assumption that Christian and modern apocalyptic aspirations are potentially benevolent; nor does he restrict his analysis to important but secondary phenomena like the absurd and rebellion that distract him from an examination of the fundamental character of modernity. According to The Fall all apocalyptic ambitions are bad and distorting because they are motivated by an unrestrained self-love. So far so good. But the analysis of The Fall goes even farther. It answers a question that Camus first posed explicitly in The Rebel but which he was struggling to articulate in several earlier works. ${ }^{220}$ Modernity represents an extreme form of self-love. True. But self-love is nothing new in itself. What then distinguishes it from the self-love of previous historical dispensations? The reason the question is pressing is due to the unusual character of modernity. Modernity's violence 
Ph.D. Thesis - R. Srigley McMaster - Religious Studies

far exceeds that of any other historical dispensation, even in relative terms. ${ }^{221}$ But in addition to that violence it has also encouraged a kind of moral confusion that is difficult to understand if not to describe. Camus offers a compelling account of it in a passage from The Rebel that we have already noted.

In more naive times, when the tyrant razed cities for his own greater glory, when the slave chained to the conqueror's chariot was dragged through the rejoicing streets, when enemies were thrown to the wild beasts in front of the assembled people, the conscience could remain firm and judgement clear. But slave camps beneath the flag of freedom, massacres justified by a the love of man or a taste for the superhuman, in one sense cripple judgement. ${ }^{222}$

According to the description modernity is both extraordinarily violent and passionately moral. How are we to explain this strange concurrence of ambitions? I think that the title of the book and the odd way in which Clamence goes about satisfying his self-love together suggest an answer to that question and go a long way to explaining the peculiar nature of modernity and its Christian origins.

Clamence is a self-lover who wants to satisfy his desires in whatever way he can and whatever the cost to others. There is nothing new about that. It is a human disposition that is possible at all times. But there is also something peculiar about Clamence's selflove that will perhaps be clearest if we contrast it with the ancients. Like Camus' conqueror ancient tyrants and demagogues (not to mention normal citizens) were certainly willing to commit immoral acts in order to serve their interests. As troubling as such deeds may have been to their finer sensibilities, nevertheless they did not feel 
Ph.D. Thesis - R. Srigley McMaster - Religious Studies compelled to hide the true character of those deeds from themselves or to construct accounts in which they appeared to be noble or good. Thucydides' accounts of Pericles' funeral oration and the speeches of the first Athenian embassy to the Lacedaemonians are a case in point. Perciles speaks about Athens' establishment of "eternal memorials" to its "friendship" and "enmity" or evil alike. ${ }^{223}$ And when the Athenian delegation questions the Lacedaemonians about their moral objections to the acquisition of empire, they do so by appealing to nature. ${ }^{224}$ "Did justice ever deter any one from taking by force whatever he could? Men who indulge the natural ambition of empire deserve credit if they are in any degree more careful of justice than they need be. ${ }^{9225} \mathrm{My}$ point is not to commend these deeds and aspirations anymore than it was Thucydides' when he first wrote about them. Rather, it is to note the frankness and clarity of the description of Athenian selfinterest and the fact that it is considered in some sense natural.

Clamence's narrative is the antithesis of this account in almost every respect. He is as immoral and self-interested as the Athenians, yet he is deeply concerned to appear moral and in a sense even to be moral. And his narrative matches his ambition. The degree of sophistry and the odd self-deception that it entails just to satisfy this ambition are staggering. Why not speak frankly about his immorality like an ancient Greek might do or like one of the early slave dealers he discusses in chapter three? This is not merely a problem of hypocrisy or an expression of the normal type of concealment necessary for unscrupulous deeds to be effective. ${ }^{226}$ Clamence desperately wants to feel himself pure 
Ph.D. Thesis - R. Srigley McMaster - Religious Studies while at the same time committing very impure acts. This is the strange phenomenon that Camus points to in The Rebel. Moderns willingly commit horrifying acts of violence yet they do so in order to fulfil a moral obligation - Camus' "slave camps beneath the flag of freedom." How are we to explain this? The title of Camus' book gives us a first clue. The Christian teaching about original sin and our fallen condition is responsible for this odd structure in Clamence's narrative and in all modern apocalyptic movements. The experience of life as radically fallen casts a dark shadow over all our dealings and implies that every human desire is somehow unnatural. However its effects are particularly problematic with regard to our least noble desires. Self-love may be ugly and out of proportion with the character of life as we all know it, but it is not therefore demonic. Yet this is precisely what Christianity teaches, and it has encouraged that desire to grow historically and to extend its ambitions in order to match its billing. Clamence's transformation of the natural and benign judgement of the laughter into the horrors of the little-ease is a concrete illustration of that change and of how it is accomplished. A selflove raised in and shaped by these Christian structures will not easily be satisfied by moderate judgements of any kind, whether for or against; and it will flatly refuse the charge of self-love or immorality when applied to its efforts to overcome what it perceives as the unnaturalness of the world. As Camus argues in The Rebel there is a deep and puritanical hatred of life at the bottom of these formulations that is antithetical to the Greek account, even in the case of its worst desires. ${ }^{227}$ In The Fall that hatred is manifest 
Ph.D. Thesis - R. Srigley McMaster - Religious Studies in Clamence's constant references to the modern desire for purification and cleansing that lies at the heart of its social and political programs. The Nazis cleanse the world of the Jews who they claim corrupt it; $;^{228}$ the bourgeois clean up human life through organized leisure activities that stymie eros and encourage a deadening rational order; ${ }^{229}$ and despite his Don Juanism and with the exception of a few good moments, there is in Clamence a sense of contempt and even hatred of women and of real erotic attachments. There is more than a little sadism in Clamence's talk of death in relationship to his partners. And one has the strong impression that real flesh and blood women are somehow deeply distasteful to him. ${ }^{230}$

The modern desire to cleanse or purify the world is a direct consequence of the Christian doctrine of the fall and original sin. So too is modernity's frightening moralism and its inability to face its own self-love frankly and to do what can be done to diminish it. Indeed the Christian and modern accounts have created an alibi for self-love that allows it to grow exponentially while maintaining its good conscience. It is not surprising in this respect to find a modern writer like Machiavelli recommending the Christian religion for anyone who would wish to secure a principality for himself and to serve his self-interest. ${ }^{231}$ Machiavelli simply notes the self-love inherent in the teaching and appropriates it for his own purposes. But he does not avail himself of the elaborate Christian assurances of good conscience, and in this sense he is more moral, or at least more honest, than those from whom he has learned. All of these elements conspire to give 
Ph.D. Thesis - R. Srigley McMaster - Religious Studies modernity its peculiar moral viciousness. The entire construction - the moral excesses and the demonization of desire - are consequences of the doctrine of the fall, which eliminates those "natural curbs" to excess that Clamence mentions and in the absence of which the judges are set loose and the world is filled with apocalyptic prophets and quacks bent on destroying the very fabric of human life. ${ }^{232}$ According to The Fall the way out of this nightmare is to follow Clamence in his awakening and to take the path that he was offered but refused - the Greeks.

After describing his adventures in debauchery and before settling permanently into the little-ease, Clamence pauses for a moments and laments: "We shall never get out of this immense holy-water font [bénitier]."233 This remark sums up the critique of modernity in The Fall. The excessive self-love apparent in modernity stems from its continuation of the Christian teachings about the fall and redemption. But unlike Clamence, Camus knows there is a way out of this situation. The nature of that escape is apparent in the Camus's use of religious imagery, particularly in The Rebel, The Fall, and the posthumously publish text, The First Man.

These titles seem to read like a lesson from the catechism. Human beings rebel against the divine order and as a consequence they are exiled from paradise and fall from their originally perfect natures. But this is not the final scene of the narrative. The story finds its completion in the healing and return of the first Adam - the first man - and the 
Ph.D. Thesis - R. Srigley McMaster - Religious Studies restoration of creation. Appearances to the contrary notwithstanding, this is not Camus' narrative. Our analyses of both The Rebel and The Fall make it clear that Camus was not furthering the Christian/modern project but criticizing it. And the substance and imagery of his books confirm it. The Christian notion of human rebellion is a distortion of its true nature that leads to modern excesses. And the fall is not an salutary insight into the nature of human evil but a false doctrine that exacerbates human self-love by encouraging its worst excesses and giving those excesses a good conscience. But how about The First Man? The first man is not the new Adam or a symbol of some anticipated redemption. Rather Camus uses the symbol to describe human nature before the fall - i.e., before or in the absence of the corruptions of the religious dogmas that have guided the West for some two thousand years. ${ }^{234}$ It is not a perfect human being that Camus means to describe, but a human being as he is naturally, with all his glories and failings. The exemplar of that nature in The First Man is constructed out of events from Camus' own life. It is his attempt to describe that Greek heart of which he often spoke. ${ }^{235}$ 
Ph.D. Thesis - R. Srigley McMaster - Religious Studies

Notes

1. In September 1952 Camus wrote to his wife, Francine: "I understand that they [Sartre et al.] are just discussing my work, and I was the first one to find it debatable, even on the deepest levels. But I have nothing to say if they are accusing me personally, because then every defense becomes a self-apology." Oliver Todd, Albert Camus, A Life, 311.

2. This was the methodology of both The Myth of Sisyphus and The Rebel.

3. See the section of "Totality and Trial" in The Rebel. Here is an example of the analysis: "Totality is, in effect, nothing other than the ancient dream of unity common to both believers and rebels, but projected horizontally onto an earth deprived of God." Albert Camus, The Rebel, 233.

4. In the final section of The Rebel Camus hesitates, and returns to the notion the modernity is a deformation of Christianity. "But when the Church dissipated its Mediterranean heritage, it placed the emphasis on history to the detriment of nature, caused the Gothic to triumph over the romance, ans, destroying a limit in itself, has made increasing claims to temporal power and historical dynamism." Ibid., 299.

5. Consider the following passage from The Rebel: "Terror and concentration camps are the drastic means used by man to escape solitude. The thirst for unity must be assuaged, even in the common grave. If men kill one another, it is because they reject mortality and desire immortality for all men." Ibid., 247.

6. Ibid, 10.

7. Both philosophical essays are prefaced with qualifications that make clear the provisional nature of the analysis. In The Myth of Sisyphus Camus says that his discussion is a "point of departure." In The Rebel he tells the reader that the book will not get to the "root of things." Albert Camus, The Myth of Sisyphus, 10 and The Rebel, 4.

8. Cited from Albert Camus, Resistance, Rebellion, and Death, 59.

9. In his Preface to the 1958 edition of The Wrong Side and the Right Side, Camus wrote: "What I have tried to say here is that in one way or another it will be like The Wrong Side and the Right Side and that it will speak about a certain form of love." Albert Camus, Lyrical and Critical Essays, 15. 
Ph.D. Thesis - R. Srigley McMaster - Religious Studies

10. During an interview in 1956 Camus said that a certain affection for the first Christian is the only thing he has in common with the character of Clamence. Albert Camus, Lyrical and Critical Essays, 320.

11. "Deprived of their natural curb, the judges, loosed at random, are racing through their job. Hence we have to try to go faster than they, don't we? And it's real madhouse. Prophets and quacks multiply; they hasten to get there with a good law or a flawless organization before the world is deserted. Fortunately, I arrived! I am the end and the beginning; I announce the law. In short, I am a judge-penitent. Albert Camus, The Fall, trans. Justin O'Brien (New York: Vintage International, 1991), 117-118.

12. In de Beauvoir's case, see her The Mandarins. In Sartre's, see his "Réponse à Albert Camus."

13. Tony Judt, The Burden of Responsibility: Blum, Camus, Aron and the French Twentieth Century (Chicago: The University of Chicago Press, 1998), 104.

14. In response to this type of interpretation, which had become fashionable in Camus' own time, he replied: "There, in parentheses, is my only similarity to the Jean-Baptiste Clamence with whom "people stubbornly insist on identifying me." Albert Camus, Lyrical and Critical Essays, 320.

15. Jean Onimus, Albert Camus and Christianity, trans. Emmett Parker (Alabama: University of Alabama Press, 1970), 92.

16. Ibid., 94-95.

17. Ibid., 100.

18. Ibid., 98 .

19. Ibid.

20. Ibid.

21. Albert Camus, Lyrical and Critical Essays, 320.

22. Onimus, Albert Camus and Christianity, 92.

23. In his various responses to Rambert, Rieux makes it clear that he does not object to Rambert's insistence on the importance of romantic love itself. "'No,' [Rieux] said 
Ph.D. Thesis - R. Srigley McMaster - Religious Studies

vehemently. 'You are not wrong.' Albert Camus, The Plague, trans. Stuart Gilbert (London: Penguin Books, 1960), 136. The most one could say critically is that Rambert's account is incomplete because it leaves no room for other loves. But this is something Rambert corrects during his time in Oran. Whatever else one might say about his achievement, he is anything but selfish.

24. Ibid., 93.

25. Augustine, The City of God, Book XIV, trans. G. Walsh, D. Zema, G. Monahan, D. Honan (New York: Image Books, 1958).

26. For a description of the little-ease, see Albert Camus, The Fall, 109-ff. For the correspondence between the Greeks and the laughter, compare Ibid., 97-98 with 96. In the later passage Camus writes: "Until then, the laughter continued to drift my way, without my random efforts succeeding in divesting it of its benevolent, almost tender quality that hurt me." See also Ibid, 39, where Clamence offers this description of his first experience of the laughter: "Please don't misunderstand me; there was nothing mysterious about that laught; it was a good, hearty, almost friendly laugh, which re-established the proper proportions" (my emphasis). The laughter is not Christian judgement or the voice of God. It is something that gently restores proportion in contrast to Clamence's exaggerated sense of himself.

27. Albert Camus, The Fall, epigraph.

28. Robert C. Solomon, Dark Feelings, Grim Thoughts: Experience and Reflection in Camus and Sartre (London: Oxford University Press, 2006), 198.

29. Albert Camus, The Fall, 67.

30. Robert Solomon, Dark Feelings, Grim Thoughts, 206.

31. Oliver Todd quotes the following remarks by Camus regarding his relationship to his wife: "I am the first one responsible, because part of me has never stopped thinking instinctively that human affairs are not serious. It's also that I have hurt so many people around me...And really I don't know how to get out of it, when I think that Francine may continue to be what she is right now." And again: "For entire days I have the most frightful opinion of myself." Oliver Todd, Albert Camus: A Life, 320, 299.

32. Aristotle, Nicomachean Ethics, Book II, 1107a 15-20.

33. Robert Solomon, Dark Feelings, Grim Thoughts, 208. 
Ph.D. Thesis - R. Srigley McMaster - Religious Studies

34. Ibid.

35. Albert Camus, The Fall, 15.

36. Ibid., 69-70.

37. Ibid., 147.

38. Robert Solomon, Dark Feelings, Grim Thoughts, 209.

39. Ibid., 207-9.

40. See Friedrich Nietzsche, On the Genealogy of Morals, trans. Walter Kaufmann (New York: Vintage Books, 1989). See also Max Scheler, Ressentiment, trans. William Holdheim (New York: Schocken Books, 1972).

41. Ibid., 207.

42. Ibid.

43. Robert Solomon, Dark Feelings, Grim Thoughts, 197.

44. Solomon writes: "His fall does indeed point to a capacity that we all share, and Christianity provides just one version of it. In this again, I think Philip Quinn is right on the mark, but Camus rightly raises the question of whether the Christian worldview is the only cure - or, rather, whether it is the cause - of this state of affairs." Ibid.

45. This is a large part of the argument of The Rebel. The same ambition is apparent in an interview with Les Nouvelles littéraires Camus gave in 1951. See Albert Camus, Lyrical and Critical Essays, 354.

46. See Saint Augustine, Homilies on the Gospel of John, V, 1, in The Nicene and PostNicene Fathers, Vol. VII, ed. P. Schaff, trans. J. Gibb and J. Innes (Grand Rapids: Wm. B. Eerdmans Publishing Company, 1956), p. 31. See Kierkegaard's similar assessment of virtue in Søren Kierkegaard, The Sickness Unto Death.

47. Jean Onimus, Albert Camus and Christianity, 92.

48. David R. Ellison, Of Words and the World: Referential Anxiety in Contemporary French Fiction, (Princeton: Princeton University Press, 1993), 27. 
Ph.D. Thesis - R. Srigley McMaster - Religious Studies

49. Ibid., 26.

50. Ibid., 27.

51. Ellison acknowledges that this may not have been Camus' intention. "It has been my purpose to show that Camus's [sic] enigmatic récit, although it may have been consciously (authorially) conceived as a text about our modern imprisonment in guilt, became, in the actual writing, the dérobade by which narration reveals its ironic relationship to the subject matter or message it conveys." Ibid., 42.

52. Ibid., 30, 42-43.

53. Ibid., 29.

54. See Ibid., 35.

55. Ibid., 27.

56. Ibid., 41.

57. Ibid., 31.

58. Ibid.

59. Albert Camus, The Fall, 117.

60. Ellison, Of Words and the World, 31.

61. Ibid., 34-35.

62. "Because the attachment of self to other is nothing more than the projection of selflove, the most adequate metaphor to express the loving relationship is that of imprisonment: 'In the end I became attached to her in much the same way as I imagine a jailer relates to his prisoner' (1506)...On the psychological level, therefore, a subject incapable of relating to the other as existential reality creates a game in which it is possible to refuse the other's identity by fictionalizing it or otherwise rendering it harmless. This happens not only in the realm of eroticism, where a jailer tries to control the secretive essence of the prisoner, but also in the political-historical arena, as Camus demonstrates in a short parable on man's need for authority." Ibid., 34.

63. Ibid., 35 
Ph.D. Thesis - R. Srigley McMaster - Religious Studies

64. Ibid., 34.

65. "No doubt this naming is he result of a fundamental tendency in language to say what is beyond words, to create a coherent metaphorics where there is nothing but a void demanding interpretation. But the naming is inevitable and productive of meanings. If Clamence had not identified his crime and assumed the cloak of guilt, there could have been no representable actions or matter for confession, but only the hovering around an absent center whose proper expression is silence." Ibid., 43.

66. Ibid.

67. Ibid., 34.

68. For an interesting analysis of this problematic and the effort overcome it, see Jean Baudrillard, The Transparency of Evil: Essays on Extreme Phenomena, trans. James Benedict (London: Verso Books, 1995). See also Jean Baudrillard, The Perfect Crime, trans. Chris Turner, (London: Verso Books, 1996).

69. Albert Camus, The Fall, 98-ff.

70. To offer only a few examples, see Albert Camus, Christian Metaphyics and Neoplatonism, trans. Ron Srigley (Columbia: University of Missouri Press, 2007), 118127; "Summer in Algiers" in Lyrical and Critical Essays, trans. Ellen Conroy Kennedy, ed. Philip Thody (New York: Vintage Books, 1970), 80-92; Notebooks 1942-1951, trans. Justin O'Brien (New York: Paragon House, 1991), 265; The Plague, trans. Stuart Gilbert (London: Penguin Books, 1960), 251.

71. Ellison, Of Words and the World, 29.

72. Ibid., 30.

73. Shakespeare, The Merchant of Venice (London: Bantam Classics, 1988), 2.5.36-7. Ellison argues that one of the difference between The Fall and the rest of Camus' books is that in the latter he seeks to escape the "sobriety of moralisme." Ibid., 27.

74. Ellison, Of Words and the World, 31.

75. There is still the odd inconsistency in Ellison's analysis. In the final line of the chapter, Ellison does suggest that the book hovers around "an absent center." Ibid., 43.

76. Albert Camus, The Rebel, 190; 233-245. 
Ph.D. Thesis - R. Srigley McMaster - Religious Studies

77. Ibid., 242-243.

78. Ellison, Of Words and the World, 42-43.

79. Albert Camus, Christian Metaphysics and Neoplatonism, 42.

80. During some of his worst post-fall moments he looks back with longing on this time of his life. It is not innocence he craves, but the innocent way in which he was able to indulge his self-love without his conscience troubling him.

81. John Burnaby's book Amor Dei is still a good source for this aspect of Augustine's work. John Burnaby, Amor Dei: A Study of the Religion of St. Augustine (Norwich: The Canterbury Press, 1991).

82. Saint Augustine, Confessions, trans. R.S. Pine-Coffin (London: Penguin Books, 1961). There are seemingly endless examples of this tension in the book. Some of my favourites occur during Augustine's description of his love of love and his attachment to the theatre in Book III and his account of the limitations of Platonic philosophy in Book VII.

83. One of the best works on the literary structure of the Confessions is Robert McMahon, Augustine's Prayerful Ascent: A Essay on the Literary Form of the Confessions (Athens: University of Georgia Press, 1989).

84. Clamence's erotic nature is apparent throughout The Fall. In Augustine's case perhaps the best comparison is with Alcibiades in Plato's Symposium. Alcibiades is unlike all the other guests at the symposium in the manner in which he is moved by Socrates' speeches, a man who claims to have "expert knowledge of nothing but erotics." Plato, Symposium in The Dialogues of Plato, trans. Seth Benardete (London: Bantam Books, 1986), 178de.

85. In the Confessions, for erotic excesses see Books II, 2, III, 1, VI, 12; for the lust for experience, Books III, 1-3, VI, 7-9; and for his relation to the highest things, Book VII, $10-21$.

86. In the Confessions, Book VII, which explores the inadequacies of the "books of the Platonists" and includes a rather dubious bit of plagiarism from the Symposium, is followed by an account of Augustine's conversion in Book VIII.

87. Albert Camus, The Fall, 117. 
Ph.D. Thesis - R. Srigley McMaster - Religious Studies

88. Ibid., 126. The allusion could easily recall Augustine's fight against the Donatists, a sect that he ultimately condoned the use of violence to suppress. Clamence claims one of the important things he discovered during his pontifical adventures was how "empires and churches are born under the sun of death." Ibid., 127.

89. Ibid., 80 .

90. The following is a good example of this struggle from the Confessions: "My inner self was a house divided against itself. In the heat of the fierce conflict which I had stirred up against my soul in our common abode, my heart, I turned upon Alypius. My looks betrayed the commontion in my mind as I explained, 'What is the matter with us? What is the meaning of this story? These men have not had our schooling, yet they stand up and storm the gates of heaven while we, for all our learning, lie here grovelling in this world of flesh and blood! Is it because they have led the way that we are ashamed to follow? Is it not worse to hold back?"' In the following chapter Augustine offers notion of the "two wills" in order to explain the difficulty of the struggle. Augustine, Confessions, Book VIII, 8-9.

91. Confession creates the illusion of having been given the inside story, which is why it is an essential element of the confidence game. For a good example of how this game looks in practice, see Herman Melville, The Confidence-Man in Herman Melville (The Library of America, 1984), 835-1112. Clamence perfects the art by giving creating the impression that he is giving the real story behind the other real story. This insider game can be played endlessly. It seems compelling to us because of the manner in which it repeats the pattens of the Christian about divine providence.

92. In part this is the argument of Christian Metaphysics and Neoplatonism. Camus continues it in his analysis of the history of metaphysical rebellion in The Rebel.

93. Harvey Mansfield does a good job of explaining this subtlety and complication. See Harvey C. Mansfield, Machiavelli's Virtue (Chicago: The University of Chicago Press, 1996).

94. "Men in general judge more by their eyes than by their hands, because seeing is given to everyone, touching to few. Everyone sees how you appear, few touch what your are; and these few dare not oppose the opinion of many who have the majesty of the state to defend them." Niccolò Machiavelli, The Prince, trans. Harvey C. Mansfield (Chicago: The University of Chicago Press, 1998), Book XVIII. 
Ph.D. Thesis - R. Srigley McMaster - Religious Studies

95. "A prince should thus take great care that nothing escape his mouth that is not full of the above-mentioned five qualities and that, to see him and hear him, he should appear all mercy, all faith, all honesty, all humanity, all religion. And nothing is more necessary to appear to have than this last quality." Ibid.

96. Ibid., VII.

97. Albert Camus, The Fall, 11.

98. Ibid., 141-142.

99. Ibid., 134.

100. See Ibid., 39 for an example of this restoration of judgement regarding his bad deeds. Regarding his good deeds, see Ibid., 86-89.

101. This is the central argument of my interpretation. I make it in detail below.

102. Albert Camus, The Fall, 84.

103. The only commentator I know of who has commented on this odd structure of Camus' cyclical books is Serge Doubrovsky in his essay "The Ethics of Albert Camus." What Doubrovsky says in this regard is extremely insightful. The problem is that it amounts only to a passing remark that is offered as part of a larger argument that is Doubrovksy's main concern. My analysis explores these structures comprehensively and deepens Doubrovky's initial insight in the process. Serge Doubrovsky, "The Ethics of Albert Camus" in Germaine Brée, Camus: A Collection of Critical Essays, ed. Germaine Brée (New Jersey: Prentice-Hall, Inc., 1962), 71-84.

104. See Albert Camus, Preface to The Wrong Side and the Right Side in Lyrical and Critical Essays, 15

105. Albert Camus, The Fall, 83, 86.

106. Ibid., 102-108.

107. The "little-ease." Ibid., 109-116.

108. Ibid., 127-ff.

109. Ibid., 144. 
Ph.D. Thesis - R. Srigley McMaster - Religious Studies

110. Ibid., 147. As indicated elsewhere in the text, Clamence is talking only to himself.

111. Ibid., 11; 20. Though the latter passage does not refer to the Holocaust directly, it does so as a statement of Clamence's ambition. This ambition extends as far as the death of all living things, though Clamence realizes their might be a solution that would afford him the same satisfaction without all the physical killing.

112. In response to the suggestion that he is digressing from his principal subject, Clamence says: "I am sticking to my subject with all that about friends and connections." Ibid., 32.

113. Ibid., 138-144. Roughly the description of his vocation as judge-penitent.

114. Ibid., 33, 34, 48, 50, 55, 58, 68, 76, 102,142 . These are only the explicit references. There are many others that make precisely the same admission without the overt language.

115. Ibid., 73.

116. See John Burnaby, Amor Dei, (Norwich: The Canterbury Press, 1991).

117. Saint Augustine, The City of God, trans. Gerald Walsh, Demetrius Zema, Grace Monahan, Daniel Honan (New York: Image Books, 1958), Book XIV.

118. Albert Camus, The Fall, 109.

119. Ibid., 117.

120. Ibid., 68.

121. Ibid., 67.

122. Ibid., 64-65.

123. Ibid.

124. Ibid., 11. The Soviets are the main target of Camus' critique of totalitarianism in The Rebel. See Albert Camus, The Rebel, 226-245.

125. In The Rebel Camus gives the example of the town of Lidice as evidence of this attempt by the Nazis to erase all evidence of their crimes. See Ibid., 184-185. 
Ph.D. Thesis - R. Srigley McMaster - Religious Studies

126. Ibid. The story received popular attention through the publication of William Styron's novel, Sophie's Choice.

127. Albert Camus, The Fall, 7.

128. Ibid., 8.

129. Ibid., 46.

130. Ibid., 14.

131. Ibid., 7.

132. Ibid., 45. This is clearly a criticism of people like Sartre and Merleau-Ponty, who provided Stalinism with arguments to justify its crimes.

133. Ibid., 6.

134. Ibid., 45.

135. Camus raises the same problem in The Rebel, though he does not answer it there. Consider the following remarks from the Introduction: "In more naive times, when the tyrant razed cities for his own greater glory, when the slave chained to the conqueror's chariot was dragged through the rejoicing streets, when enemies were thrown to the wild beasts in front of the assembled people, the conscience could remain firm and judgement clear. But slave camps beneath the flag of freedom, massacres justified by a the love of man or a taste for the superhuman, in one sense cripple judgement." Albert Camus, Essais, 413.

136. Albert Camus, The Fall, 39.

137. Ibid., 38-39.

138. Ibid.

139. The self-love formulation, his good deeds, and the notion of completion are all thinly veil references to Saint Augustine, whose work Camus explored in Christian Metaphysics and Neoplatonism. The Vert-Galant is of course Henry IV. Clamence is fond of such comparisons. Earlier in the text he writes of himself: "Half-Cerdan, half de Gaulle, if you will." Albert Camus, The Fall, 54. Toward the end of the book the comparisons finally reflect Clamence's real ambitions: the pope, John the Bapist, Jesus, 
Ph.D. Thesis - R. Srigley McMaster - Religious Studies

and God himself. Ibid., 120-ff, 146, 143.

140. Ibid., 39.

141. Ibid., 96.

142. Ibid.

143. Ibid., 89-91; 86-89.

144. Ibid., 89-90.

145. Plato, Gorgias, trans. James H. Nichols (Ithaca: Cornell University Press, 1998), $512 \mathrm{e}$.

146. Ibid., 511a.

147. Plato, Phaedo, trans. Hugh Tredennick, in The Collected Dialogues of Plato, eds. Edith Hamilton and Huntington Cairns (Princeton: Princeton University Press, 1961), 64a.

148. Albert Camus, The Fall, 80.

149. Ibid., 86.

150. Plato, The Republic of Plato, trans. Allan Bloom (New York: Basic Books, 1968), 604bc.

151. Plato, The Laws of Plato, trans. Thomas Pangle (Chicago: The University of Chicago Press, 1980), 803b.

152. Ibid., 803c-e.

153. Albert Camus, The Fall, 88.

154. Camus has more than a passing acquaintance with Plato's dialogue. It likely was a mix of direct reading in the dialogues and the work on Plato done by his friend, Brice Parain. See Albert Camus, "On a Philosophy of Expression," in Lyrical and Critical Essays, 228-241.

155. Ibid., 803c. 


\section{Ph.D. Thesis - R. Srigley McMaster - Religious Studies}

156. This is consistent with an argument that Camus makes on several occasions. He admitted to having a "sense of the sacred" or divine but did not believe in an after life. Christianity's apocalyptic aspirations compromised its ethical insight regarding divine reality. See Albert Camus, Lyrical and Critical Essays, 364. Camus offers a similar insight in the following remark: "The limits. Thus I shall say that there are mysteries it is suitable to enumerate and to mediate. Nothing more." Albert Camus, Notebooks 1942$1951,126$.

157. Consider the following remark from chapter four: "Most often, on the other hand, we confess to those who are like us and who share our weaknesses. Hence we don't want to improve ourselves or be bettered, for we should first have to be judged in default." Albert Camus, The Fall, 83. Or this: After describing his performance during the motorcycle incident, he wonder about a different sort of response about which there is absolutely nothing impossible: "If I had been the friend of truth and intelligence I claimed to be, what would that episode have mattered to me? It was already forgotten by those who had witnessed it. I'd have barely accused myself of having got angry over nothing and also, having got angry, of not having managed to face up to the consequences of my anger, for want of presence of mind." Ibid., 55. Or this. After saying that slavery with a smile in inevitable, Clamence suggests that we could also face up to the situation much more honestly. "We owe them that compensation, don't we? In that way, [by refusing to admit what we are doing] they will continue to smile and we shall maintain our good conscience. Otherwise, we'd be obliged to reconsider our opinion of ourselves; we'd go mad with suffering, or even become modest - for everything would be possible." Ibid., 47.

158. Concerning the hypothetical nature of the image, see Ibid., 110.

159. Ibid., 96.

160. Ibid., 141-142.

161. Ibid., 96.

162. Ibid., 72.

163.Ibid., 96.

164. Ibid., 97. 
Ph.D. Thesis - R. Srigley McMaster - Religious Studies

165. For a good discussion of the modern conception of the physical universe and its teleological aspriations see Eric Voegelin, "The Moving Soul" in The Collected Works of Eric Voegelin, Vol. 28, What is History? And Other Late Unpublished Writings, eds. Thomas Hollweck and Paul Caringella (Baton Rouge: Louisiana State University Press, 1990), 163-172.

166. See Jean Baudrillard, The Perfect Crime.

167. Ibid.

168. For an further elaboration of the meaning of this distinction, see Eric Voegelin, "Configurations of History," in The Collected Works of Eric Voegelin, Vol. 12, Published Essays 1966-1985, ed. Ellis Sandoz (Baton Rouge: Louisiana State University Press, 1990), 95-114.

169. Albert Camus, The Fall, 97.

170. Camus is ambivalent about the role of Israel in the advent of modernity. See my discussion of this ambivalence in chapter two above.

171. Ibid. The lines with which this passage concludes are a joke at Sartre's and Jeanson's expense. "Since then, Greece itself drifts somewhere within me, on the edge of my memory, tirelessly... Hold on, I, too, am drifting. I am becoming lyrical! Stop me, cher, I beg you." In their responses to The Rebel both men mocked Camus' lyricism as beautiful but empty speech. Camus pays them back by showing them the kind of company their mockery has them keep. See Francis Jeanson, "Albert Camus ou l'âme révoltée," Les temps modernes, no. 79 (mai 1952), 2070-2090. See also Jean-Paul Sartre, "Réponse à Albert Camus," Les temps modernes, no. 82 (août 1952), 334-353.

172. Albert Camus, The Fall, 98.

173. The playfulness is apparent in the language of the description: "I felt as if we were scudding along, night and day, on the crest of short, cool waves in a race full of spray and laughter." The sense of measure is found in the images of clarity, the absence of confusion, and the corresponding ability to navigate among the islands meaningfully.

174. This notion of harmony with oneself and the world is a constant theme in Camus' early writings. Its content here matches those early work perfectly. See The Wrong Side and the Right Side and Nuptials in Albert Camus, Lyrical and Critical Essays, 19-105. See also Camus' 1958 Preface to the former work in Ibid., 5-17. 
Ph.D. Thesis - R. Srigley McMaster - Religious Studies

175. This is not an ideological assertion. It may be that the Greeks are the best in the West. But Clamence suggests that similar insights and practices can be found in the "Orient" also. Ibid.

176. Kierkegaard was right in his account of this opposition but wrong in his assessment of which side to prefer. "Very often, however, it is overlooked that the opposite of sin is by no means virtue... No the opposite of $\sin$ is faith, as it says in Romans 14:23: 'whatever does not proceed from faith is sin'." Søren Kierkegaard, The Sickness Unto Death: A Christian Psychological Exposition for Upbuilding and Awakening, 82. Whatever is not faith is sin, and that includes virtue. Camus explores the formulation in Christian Metaphysics and Neoplatonism.

177. Friedrich Nietzsche, Beyond Good and Evil: A Prelude to a Philosophy of the Future, trans. Walter Kaufmann (New York: Vintage Books, 1966), Part Four, 168.

178. Albert Camus, The Fall, 83-84.

179. Ibid., 84 .

180. Ibid., 83.

181. Ibid., 14.

182. Ibid., 116.

183. The follow account is derived largely from Kierkegaard. See Søren Kierkegaard, The Concept of Anxiety: A Simple Psychologically Orienting Deliberation on the Dogmatic Issue of Hereditary Sin, ed. and trans. Reidar Thomte (Princeton: Princeton University Press, 1980).

184. Genesis 3: 7, King James Bible.

185. See Camus discussion of this teaching in his chapter on Augustine in Christian Metaphysics and Neoplatonism.

186. In the modern period, the most vivid depiction of that movement from a Christian standpoint is the character Ivan Karamazov in Dostoevsky's The Brother Karamazov. See particularly the chapters "Rebellion" and "The Grand Inquisitor." Fyoder Dostoevsky, The Brothers Karamazov, trans. Constance Garnett (New York: W. W. Norton \& Company, 1976). 
Ph.D. Thesis - R. Srigley McMaster - Religious Studies

187. In the Christian theology that grew out of this doctrine the experience has become even more complex and dialectical. The usual practice is to direct any criticism of the condition back to the critic as further evidence of his sinful nature generally.

188. This teaching is expressed with great clarity by Kierkegaard. "It is specifically the concept of sin, the teaching about sin, that most decisively differentiates Christianity qualitatively from paganism, and this is also why Christianity very consistently assumes that neither paganism nor the natural man knows what sin is; in fact, it assumes that there has to be a revelation from God to show what sin is." Søren Kierkegaard, The Sickness Unto Death: A Christian Psychological Exposition for Upbuilding and Awakening, 89.

189. Albert Camus, The Fall, 117.

190. In the Republic Socrates tells Glaucon in the Republic, "'it is finest to keep as quiet as possible in misfortunes and not be irritated, since the good and bad in such things aren't plain, nor does taking it hard get one anywhere, nor are any of the human things worthy of great seriousness; and being in pain is an impediment to the coming of that thing the support of which we need as quickly as possible in these cases.' 'What do you mean?' he said. 'Deliberation,' I said, 'about what has happened'." Plato, Republic, trans. Allan Bloom (New York: Basic Books Inc., 1968), 604bc.

191. Dostoevsky's account of the teachings of Father Zosima is one of the best contemporary discussions of this aspiration. Fyoder Dostoevsky, The Brothers Karamazov, 266-303. See particularly the section entitled "Of Prayer, of Love, and of Contact with Other Worlds," 297-300.

192. Albert Camus, The Fall, 109-110.

193. Ibid., 110.

194. "With the intelligent ones it takes time. It is enough to explain the method fully to them. They don't forget it; they reflect. Sooner or later, half as a game and half out of emotional upset, they give up and tell all." Ibid., 141.

195. Ibid., 138.

196. See Nietzsche's history of the origin of Christianity in The Anti-Christ. Friedrich Nietzsche, Twilight of the Idols/The Anti-Christ, trans. R. J. Hollingdale (London; Penguin Classics, 1990), 24-27. For a similar account, see also Friedrich Nietzsche, On the Genealogy of Morals/Ecce Homo, trans. Walter Kaufmann and R. J. Hollingdale 
Ph.D. Thesis - R. Srigley McMaster - Religious Studies

(New York: Vintage Books, 1989).

197. As Clamence makes absolutely clear, he absolves no one. Albert Camus, The Fall, 143.

198. Clamence's ultimately aim is to elevate himself to a position from which he can judge all things. "How intoxicating to feel like God the Father and to hand out definitive testimonials of bad character and habits." Ibid., 143.

199. See Martin Buber's essay “The Tree of Knowledge." There Buber writes of the fall: "This stern benefaction is preceded by the passing of sentence. It announces no radical alteration of that which already exists; it is only that all things are drawn into the atmosphere of oppositeness... But the curse conceals a blessing. From the seat, which had been made ready for him, man is sent out upon a path, his own, the human path. That this is the path into the world's history, that only through it does the world have a history and a historical goal - must, in his own way, have been felt by the narrator." Martin Buber, On the Bible: Eighteen Studies, ed. Nahum Glatzer, New York: Schocken Books,1982), 21.

200. The "means" formulation is evident in the following lines: "Because I longed for eternal life, I went to bed with harlots and drank for nights on end." Albert Camus, The Fall, 102.

201. Ibid.

202. Plato, Republic, 614b-621d. Unlike the extraordinary violence and sexual disquiet (I will not say repression) that runs throughout the account in Revelation, the Republic offers a sustained criticism of such things, whether in this life or the next, and encourages measure and good judgement in comparison.

203. Albert Camus, The Fall, 142-143.

204. Ibid., 141.

205. Ibid., 141-142.

206. Ibid., 34 .

207. Ibid., 84-85. 
Ph.D. Thesis - R. Srigley McMaster - Religious Studies

208. "Covered with ashes, tearing my hair, my face scored by clawing, but with piercing eyes, I stand before all humanity recapitulating my shames without losing sight of the effect I am producing, and saying: 'I was the lowest of the low.' Then imperceptibly I pass from the 'I' to the 'we.' When I get to 'This is what we are,' the trick has been played and I can tell them off. I am like them, to be sure; we are in the soup together. However, I have the superiority in that I know it and this gives me the right to speak." Ibid., 140.

209. Ibid., 85.

210. "What can one do to become another? Impossible. One would have to cease being anyone, forget oneself for someone else, at least once. But how?” Ibid., 144-145.

211. Ibid., 117.

212. Ibid., 142.

213. Ibid.

214. For a good discussion of the Nazi practice and ideology, see James Rhodes, The Hitler Movement: A Modern Millenarian Movement (Stanford: The Hoover Institution Press, 1980). For an comprehensive analysis of the Soviet prison system and its aims, see Aleksandr Solzhenitsyn, The Gulag Archipelago, Vols. 1-3, trans. Thomas P. Whitney (New York: Harper \& Row, Publishers, 1973-1974). For an interesting discussion of the modern technological pursuit of perfection and its consequences, see Jean Baudrillard, The Perfect Crime.

215. See Norman Cohn, Cosmos, Chaos, and the World to Come: The Ancient Roots of Apocalyptic Faith, $2^{\text {nd }}$ ed. (New Haven: Yale University Press, 2001).

216. See Francis Fukuyama, The End of History and the Last Man (New York: Perennial, 1992). See also Eric Voegelin, The New Science of Politics (Chicago: The University of Chicago Press, 1952).

\section{Albert Camus, The Fall, 117-118.}

218. The concrete consequences of these movements have been well documented. Stéphane Courtois estimates that the 'Communist' wing of modernity alone is responsible for the deaths of almost 100 people. See Stéphane Courtois et al., The Black Book of Communism, trans. Jonathan Murphy and Mark Kramer (Cambridge: Harvard University Press, 1999), 4. 
Ph.D. Thesis - R. Srigley McMaster - Religious Studies

219. Clamence discovers this limitation earlier in the book during his discussion of women. If you kill everyone, who will be left to adore you? Ibid., 67, 143.

220. See Albert Camus, "Helen's Exile" and "Prometheus in the Underworld" in Lyrical and Critical Essays, 148-142, 148-153.

221. See Niall Ferguson, The War of the World: Twentieth Century Conflict and the Descent of the West (London: Penguin Books, 2006), xxxiv.

222. Albert Camus, Essais, 413.

223. Thucydides, History of the Peloponnesian War, trans. Benjamin Jowett (Amherst: Prometheus Books, 1998), II, 41.

224. Camus makes a similar point in The Rebel about the manner in which Callicles objects to Socrates notion of virtue in the Gorgias. "Even when Plato anticipates, with Callicles, the most common type of Nietzschean, even when the latter exclaims: 'But when a man appears who has the necessary character...he will escape, he will trample on our formulas, our magic spells, our incantations, and the laws, which are all, without exception, contrary to nature. Our slave has rebelled and has shown himself to be the master' - even then, though he rejects law, he speaks in the name of nature." Albert Camus, The Rebel, 27-28. Like so much of the analysis of The Rebel, Camus does not pause here to work out the consequences of this important insight.

225. Thucydides, History of the Peloponnesian War, I, 76.

226. See Niccolò Machiavelli, The Prince, trans. Harvey Mansfield (Chicago: The University of Chicago Press, 1998).

227. “[Joseph] Maistre hated Greece (it also irked Marx, who found any form of beauty under the sun completely alien), of which he said that it had corrupted Europe by bequeathing it its spirit of division. It would have been more appropriate to say that Greek thought was the spirit of unity, precisely because it could not do without intermediaries, and because it was, on the contrary, quite unaware of the historical spirit of totality, which was invented by Christianity and which, cut off from its religious origins, threatens the life of Europe today. 'Is there a fable, a form of madness, a vice which has not a Greek name, a Greek emblem, or a Greek mask?' We can ignore the outraged puritanism. This passionate denunciation expresses the spirit of modernity at variance with the ancient world and in direct continuity with authoritarian socialism." Albert Camus, The Rebel, 193. As to the Greeks at their worst, Camus writes: "The Greeks are never vindictive. In 
Ph.D. Thesis - R. Srigley McMaster - Religious Studies

their most audacious flights they always remain faithful to the idea of moderation, a concept they deified. Their rebel does not range himself against all creation, but against Zeus, who is never anything more than one god among many and who himself was mortal... It is a question settling a particular account, of a dispute about what is good, and not a universal struggle between good and evil." Albert Camus, The Rebel, 27.

228. Albert Camus, The Fall, 11.

229. Ibid., 7-8.

230. Ibid., 58, 63-67.

231. Niccolò Machiavelli, The Prince, XVIII. "A prince should take care that nothing escape his mouth that is not full of the above-mentioned five qualities and that, to see him and hear him, he should appear all mercy, all faith, all honesty, all humanity, and all religion. And nothing is more necessary to appear to have than this last quality. Men in general judge more by their eyes than by their hands, because seeing is given to everyone, touching to few. Everyone sees how you appear, few touch what you are."

232. Albert Camus, The Fall, 117. Camus' criticism of the doctrines of the fall and original sin and his understanding of their connection to modernity date back at least to 1950. "The revolutionary spirit rejects original sin. By so doing, he sinks into it. The Greek spirit doesn't think about it. By so doing, it escapes it." Albert Camus, Notebooks 1942-1951, 265.

233. Ibid., 109; Albert Camus, Théâtre, récits, nouvelles (Paris: Gallimard, 1962), 1531.

234. "For the past two thousand years the Greek value has been constantly and persistently slandered. in this regard Marxism took over from Christianity." Albert Camus, Notebooks 1942-1951, 263.

235. Albert Camus, Lyrical and Critical Essays, 357. 
Ph.D. Thesis - R. Srigley McMaster - Religious Studies

Chapter Four: Before the Fall

Learn to love what is imperfect.

Albert Camus

The First Man is an incomplete manuscript that was published posthumously some thirty-five years after Camus' death. ${ }^{1}$ All that we possess is the first part of the text and perhaps a portion of the second, both of which are unedited. ${ }^{2}$ Camus' notes indicate that the original plan of the novel was a triptych organized according to three themes or subjects: " 1 st $P$ art: The Nomads, $2^{\text {nd }}$ Part: The First Man, $3^{\text {rd }}$ Part: The Mother." ${ }^{\text {"3 }}$ The organization seems to have changed in the writing. The title of the first part in the extant manuscript is not "The Nomads" but "Search for the Father." I think this change is significant for the book's symbolism, but more of that in a moment. The text is an autobiographically inspired narrative that traces the journey of a young man from the poorest neighbourhoods of Algiers to the heights of European power and fame. The manuscript breaks off before giving an account of his life in the later dispensation. What we learn of mostly in The First Man are Jacques Cormery's various attempts to gain some knowledge of his father and of his childhood and adolescence in Belcourt, the poor quarter of Algiers where Camus himself was raised. Because of its incomplete character anything we say about the book will therefore be tentative and provisional at best. We simply do not know what Camus would have done with the manuscript had he lived to complete it. But that limitation having been admitted, there are nonetheless a number of 
Ph.D. Thesis - R. Srigley McMaster - Religious Studies things we do know about the book, particularly about its responses to the types of questions I have been exploring in this work. The following chapter is my attempt to explain some of them.

My analysis of The First Man is comprised of two parts. The first part is an interpretation of the manner in which Camus recasts the experience of suffering or misfortune from which Christian and modern apocalyptic formulations arise in commonsense language symbols derived from his own early experience of life. Camus' aim in reinterpreting these experiences in this way is to offer an alternative account that better explains their nature while also easing the apocalyptic ambitions that they are used to justify. The second part examines Camus' use of a particular Greek text - Plato's Symposium - as a template for organizing the general structure of the book and illuminating the meaning of several of Jacques' early religious and philosophical experiences. This textual organization of The First Man continues the recasting of experience that I describe in part one. But it also adds to that analysis by indicating in an exemplary way how the Greeks generally and Plato in particular offer more compelling accounts of this range of experience. These insights raise two further questions concerning the construction of The First Man. The first concerns its relationship to the analysis of The Fall; the second the manner in which it completes the project of the cyclical books. A few words in response to both questions will help to orient my discussion. 
Ph.D. Thesis - R. Srigley McMaster - Religious Studies

The First Man returns to the experiential sources of Camus' best insights into human nature $e^{5}$ as required by the plan of the cyclical book and it completes the analysis of The Fall by continuing its religious symbolism and making good on its promise of an account that is free of the distorting influence of the Christian doctrine. As to the latter aim the most obvious connection between the two texts is found in the symbolism of their titles. The reversal of the chronology of the events of the biblical account is our first indication of the meaning of that symbolism. In The Fall Camus argues that it is precisely the Christian doctrine of the fall and its various modern appropriations that are responsible for the apocalyptic excesses of our time. His analysis of Clamence's "fall" and the manner in which he reformulates the experience illuminates the character of the Christian teaching and the motives for its creation. To state Camus' main critical insight simply, there is no fall. The Christian teaching is not a description of the human condition but a construction that serves several different purposes simultaneously, the most significant of which is to satisfy human self-love in a way that shields it from reproach and self-criticism more effectively than the various strategies of the ancients. ${ }^{6}$ In The Fall Camus analyzes that teaching critically but does not offer an account of human life that is free of its influence. That positive account does not come until The First Man. In this book Camus sets out to describe the character of human life as it is before the fall or apart from the influence of the Christian teaching about that event. He concludes that like Jacques Cormery we are all the first man. ${ }^{7}$ To see this is all we need do is look around 
Ph.D. Thesis - R. Srigley McMaster - Religious Studies and within us and describe what we see and feel. ${ }^{8}$ Camus' book is exemplary because it provides us with a vivid and compelling image of how these things are done and reminder of all that we have lost in our frantic rush for perfection.

The First Man opens with an exploration of Jacques Cormery's attempt to learn something about his father. Henri Cormery was killed in 1914 during the Battle of the Marne when Jacques was only one year old. ${ }^{9}$ Apart from a few scraps of information here and there Jacques manages to learns almost nothing about the man through his various inquires and conversations. His mother cannot even recall with any certainty his full name, let alone the sorts of things Jacques seeks to know. ${ }^{10}$ Jacques' mature explanation of this oblivion of the past is both social and natural. For the poor the demands of the present are so overwhelming and imperious that there is little time for reflection on what has been. There is a physical or economic component to this absence of memory: there are fewer "landmarks in space" in the lives of the poor because they "seldom leave the place where they live"; and there are fewer landmarks in time because their lives "are gray and featureless." Jacques usually associates it with the bareness of North Africa and the manner in which it relentlessly draws back into itself all traces of human civilization. ${ }^{12}$ Compared to this landscape human life is but a fleeting shadow to which people vainly try to give permanence. The poor are more in accord with this aspect of the cosmos than are the rich 
Ph.D. Thesis - R. Srigley McMaster - Religious Studies and ambitious who seek by all means to endure and stand out. For Jacques' family, and particularly for his mother, it is otherwise. Everything gets swallowed up in a forgetfulness that is virtually complete. And so he is able to discover almost nothing about his father apart from a few briefly stated facts and characteristics. ${ }^{13}$

The failure proves instructive. The genealogical analysis provides Jacques with some insight into his father's character and also into his own. But the real lessons come only after he abandons that analysis and faces directly the world that draws all human things into this oblivion or forgetfulness, rich and poor alike. The genealogy was Jacques' attempt to discover who he was or his nature. In this context nature means the sorts of things he claims to have lacked while growing up in Algiers - ethics, guidance, religion. "And the sons and grandsons of these had found themselves on this land as he himself had, with no past, without ethics, without guidance, without religion." ${ }^{14}$ But what Jacques eventually learns is that these absences are neither unnatural nor lamentable and that neither is the absence of his father in either a physical or symbolic sense. Fathers die before their sons, particularly in times of war. That is the order of life. And war itself is not unnatural. ${ }^{15}$ Moreover the world is not without order. The absence of guidance, ethics, and religion notwithstanding, that order is apparent to both the haves and have-nots of human culture and civilization through its quiet but abiding presence, though that presence may also be ignored or silenced. In The First Man history, culture, and civilization are almost always presented as human constructs - artificial and ephemeral 
Ph.D. Thesis - R. Srigley McMaster - Religious Studies

though also somehow necessary. ${ }^{16}$ The world is what endures. It may be less forthcoming with its lessons than most human traditions, but they are ultimately more instructive and salutary. ${ }^{17}$ This is why Jacques ultimately learns more about his father through the random stories of those who first settled in Algeria and from his observation of the lives of those who now inhabit it than he does from all his genealogical efforts. ${ }^{18}$ His father's truest nature and his own are writ large across the land that stands before him each day and before all others who inhabit it. ${ }^{19}$ Henri Cormery is the first man, but so is Jacques, and so is every human being born into the world. ${ }^{20}$ This understanding runs throughout the book as a guide for the analysis and the source from which arises its emotional climate. It is the reason why the account of life that it offers is completely free of the world weariness of a doctrine like Augustine's saeculum senescens and the boredom of the post-historical life of post-modern man. ${ }^{21}$

The first thing one notices when reading The First Man is the extraordinary density or richness of the experiences Camus describes. Camus once lamented the disappearance of landscapes from modern art. Here they come back with a vengeance. The sounds and smells and even the climate of North Africa are felt on almost every page. The world that Camus depicts is dense with real things that shake or move Jacques in various ways. The smell of the cedar chips at the cooperage, the dusty and sun-baked streets of Belcourt on a Sunday afternoon in August, and the dark and foreboding yard 
Ph.D. Thesis - R. Srigley McMaster - Religious Studies where he goes to fetch the chicken for slaughter - all this reveals a world full of meaning, sometimes frighteningly so. This type of description is intentional. In The Rebel Camus argues that the principal problem with the Christian teaching about the drama of fall and redemption is that it "empties the world of its substance."22 The argument is roughly equivalent to Voegelin's notion of dedivinization but without the approbative sense that Voegelin occasionally attaches to it. ${ }^{23}$ It captures the sense of emptiness that modern philosophy either relishes or bravely attempts to overcome and gives an account of its origin. ${ }^{24}$ Camus' response to the problem in The First Man is more compelling than even the best arguments of The Myth of Sisyphus and The Rebel because it refuses to accept the problem on its own terms and instead offers an affirmative account that rests on simple observation and description, albeit very astute observation and description. The human will is not as powerful as we might be tempted to think by the accomplishments of our technologically driven science; and despite the presuppositions of our leading ideologies the world is never silent. ${ }^{25}$ What Camus says about the struggles and meanings it entails corrects these modern assumptions and replaces their apocalyptic excesses with truer, more moderate explanations of the character of human life. I turn to those explanations now. They form the heart of Camus' positive analysis in The First Man.

There are hope and despair and tension and opposition in the world of The First Man because such things exist in life. But they are not conceived apocalyptically. There is a sense of measure in the way Jacques describes almost everything he experiences or 
Ph.D. Thesis - R. Srigley McMaster - Religious Studies

witnesses. Moderate does not mean mediocre or complacent, however. There is a richness to his judgement that is less intense or exciting than what we find in apocalyptic accounts but far more meaningful once the religious and modern pyrotechnics have abated. It may not thrill in the same way, but the wisdom Jacques offers is something that will get you to work in the morning.

It is difficult to say which tension or opposition is most basic in The First Man and which best accounts for the character of life as Jacques experiences it. Is it Jacques' poverty and the silence of his mother versus the world of learning and culture he discovers at the lycée and in books? ${ }^{26}$ Or is it the anonymity of North Africa in comparison to the fame and notoriety he achieves in Europe $?^{27}$ Or are these merely two sides of the same coin? In The Wrong Side and the Right Side Camus says that he does not want to choose between the wrong and right sides of the world and does not like a choice to be made. ${ }^{28}$ The magnanimity of this statement is due to his awareness of his natality and mortality. ${ }^{29}$ Camus has preferences, certainly. The beauty of Venice and Genoa is for him preferable to the damp gray loneliness of Prague..$^{30}$ Yet life itself includes both places and its meaning seems to lie in the movement between the two aspects of the world that they represent. The best life is achieved through the acquisition of the judgement and insight necessary to negotiate one's way among these experiences and to do so sensitively and thoughtfully. You can skip Prague with its dreary darkness if you wish, but you cannot avoid the darkness in life that Prague represents and that is 
Ph.D. Thesis - R. Srigley McMaster - Religious Studies found in Genoa and Venice too. ${ }^{31}$

In The First Man good and bad are never understood apocalyptically and they are never taken as descriptive of any naturally occurring thing. The indices Jacques uses to describe life are always those of better and worse, not good and evil. The lives of the poor in Belcourt may be truer or more sound than those of the rich, but they are not for that reason perfect. Uncle Ernest is an admirable man in many ways, but he is also "ignorant" and "mulish." 32 This is not liberal mediocrity or an unwillingness to make judgements on Camus' part. The book is filled with judgements of the rich and poor alike that are penetrating and insightful. Rather it indicates Camus' awareness that life simply does not divide itself neatly into the categories of saved and damned so earnestly employed by Christian and modern apocalyptic thinkers. Utopian aspirations are usually not content with promises of perfection in a future dispensation. Perfection or at least intimations of it must also be experienced in the here and now. Jacques' descriptions of human nature undermine this sensibility or aspiration by showing how unfaithful it is to the actual texture of things and perhaps also by reminding us of a time in our own lives when we experienced life without the mediating influence of such categories - our childhood.

The moderation of Jacques' judgement is particularly apparent in the way he responds to things he finds ugly or repellent. Life in the "light of the first mornings of the world" may be preferable to "the world of the men of his time and its dreadful and exalted history," but the latter has to be faced nonetheless and responded to in some 
Ph.D. Thesis - R. Srigley McMaster - Religious Studies way. ${ }^{33}$ The opposition between nature and history that Camus occasionally posits in The Rebel is not present here in any form. ${ }^{34}$ In The First Man history is not nature's antithesis; and though the latter may be dreadful, it need not be. Even the men in the story who are most attuned to nature's rhythms - Ernest, the Arabs, the men at the cooperage - have histories and are subject to the vicissitudes of time. Indeed they are more so than their wealthy counterparts because there is little to protect them from history's harshest aspects. Their lives, too, are history. Less exalted than the modern versions, certainly, but for Jacques they offer more fitting examples of how to comport oneself in relation to the changes and movements that make up human life. Modern history is a corruption of that effort whose excess lies in its unwillingness to relinquish back to nature and its "immense oblivion" that portion of reality that is the self. Camus illuminates this excess by contrasting modernity's exalted history with Jacques' reflections on his father's grave and his own mortality.

And yet now he knew from the bottom of his heart that Saint-Brieuc and what it represented had never been anything to him, and he thought of the worn and green-encrusted gravestones he had just left, acknowledging with a strange sort of pleasure that death would return him to his true homeland and, with its immense oblivion, would obliterate the memory of that alien and ordinary man who had grown up, had built in poverty, without help or deliverance, on a fortunate shore in the light of the first morning of the world, and then alone, without memories and without faith, he had entered the world of the men of his time and their dreadful and exalted history. ${ }^{35}$

We all owe nature a death. Though we may try to deceive ourselves that this is not so, such ambitions do not often repay the effort necessary to sustain them. Usually they result 
Ph.D. Thesis - R. Srigley McMaster - Religious Studies in little more than empty, wooden images of our self-love, and not the living virtues and insights necessary to the best life. Camus offers an account of this disposition in Nuptials. "The most loathsome materialism is not the kind people usually think of, but the sort that attempts to let dead ideas pass for living realities, diverting into sterile myths the stubborn and lucid attention we give to what we have within us that must forever die."36

The same type of moderation is apparent in Jacques' other judgements. One of the best examples is found in his partial reformulation of the communist/bourgeois opposition. Against the revolutionary teaching of the Marxists he claims that while the various working class groups of Algeria are generally tolerant of one another they are extremely xenophobic and in no way the model proletariat of the ideology when it comes to matters of employment. The men in Jacques' life would accuse "in turn the Italians, the Spaniards, the Jews, the Arabs, and finally the whole world of stealing their work." ${ }^{\text {"37 }}$ The point of the accusations is not a desire for mastery or wealth or leisure as the socialist ideology claims, but ironically for more servitude.

It was not for mastery of the earth or privileges of wealth and leisure that these unexpected nationalists were contending against other nationalities; it was for the privilege of servitude. Work in this neighborhood was not a virtue but a necessity that, in order to survive, led to death. ${ }^{38}$

This analysis violates the Marxist doctrine in a variety of ways, but nowhere more so than in its claim that there are aspects of human life that affect the movements of history other than the economic ones recognized and taught by the official doctrine. Moreover it does 
Ph.D. Thesis - R. Srigley McMaster - Religious Studies

so in a way that contradicts the doctrine's claim to establish historical and economic perfection or to be the harbinger of that perfection.

A similar sort of critique is apparent in Jacques' assessment of the other side of the opposition, the bourgeois. During one of his summer holidays Jacques is forced by his grandmother to work in order to support the family and is made to lie publically for the privilege of doing so. ${ }^{39}$ The job is simple office work and Jacques despises it. The problem is not that he is unwilling to work but that the work itself is empty or meaningless. Unlike the work he witnessed in the cooperage, where the efforts of a skilled craftsman would lead to the construction of an object "the worker could contemplate," here the work produces nothing..$^{40}$

[T] his office work came from nowhere and led nowhere. Selling and buying, everything turned on these ordinary, petty actions. Although he had lived till then in poverty, it was in this office that Jacques discovered the mundane, and he wept for what he had lost. ${ }^{41}$

This is an astute analysis. The world has its emptiness and life can be harsh and bleak. But these are not the same thing as the emptiness Jacques discovers through his brief stint in the world of bourgeois capital. With the little he has Jacques still feels richer than those who inhabit this world and live according to its aspirations. Whether through neglect or ambition or some strange religious aspiration ${ }^{42}$ their actions open up an artificial emptiness below or beyond the natural emptiness of the world that Jacques describes elsewhere. ${ }^{43}$ Yet the bourgeois are not for all that evil. ${ }^{44}$ Jacques describes the 
Ph.D. Thesis - R. Srigley McMaster - Religious Studies disposition of those he encounters in the office and tries to account for their presence there. But his descriptions of their failings never go beyond the normal range of human vice - servility, inattention, resentment. ${ }^{45}$ This does not mean that Jacques sits lightly to such motivations and dispositions or to the "soulless" emptiness they encourage. ${ }^{46} \mathrm{He}$ does not. Camus allows his distaste for these things to be felt through a charming scene in which Jacques, fed up with the meaninglessness of his daily routine, seeks a reprieve by escaping to the dingy courtyard behind the office where he can savour the pungent "odor of urine" emanating from the Turkish toilet. ${ }^{47}$ And we should not forget the other experience that Camus associates with Jacques' escape from the stifling bourgeois world. Beyond the familiar odors of the neighbourhood stirring within him there is another obscure desire he experiences that is associated with the glimpse he catches of Mrs. Raslin's legs. ${ }^{48}$

We can sense from these images just how far down the ladder of human ambitions bourgeois capital is for Camus without falling prey to any apocalyptic judgement about its character. In this regard Camus' assessment is even more penetrating than Marx's, who repeats the ugliness and violence of the bourgeois world in his own revolutionary politics. $^{49}$

There is another example of the moderation of Jacques' judgement that merits discussion because it corrects a misunderstanding that appears occasionally in The Rebel and that underlies in part the apocalyptic aspirations explored in The Fall. It occurs 
Ph.D. Thesis - R. Srigley McMaster - Religious Studies during his visit to the veterans hospital where he encounters concretely the consequences of war and the nature of human suffering. ${ }^{50}$ Apocalyptic accounts interpret suffering and evil as objections to human existence as we experience it in the present and argue that they provide the clearest grounds we have for needing a world other than the one we have. ${ }^{51}$ Just as Clamence exacerbates the nature of his fall all the better to justify his utopian solution, apocalyptic thinkers exacerbate the nature of human suffering in order to justify their utopian aims as well as the less than utopian means they claim to be necessary in order to achieve them. Confusion about this structure of apocalyptic thinking is what most compromises the argument of The Rebel. Though Camus' principal aim in that book is to critique the excesses of these apocalyptic aspirations he sometimes accepts the exacerbated or distorted account of human suffering on which they rely for their meaning. ${ }^{52}$ This is what creates the impression that the book's argument is self-defeating or circular and the sense that Camus is favourably disposed, if not to apocalyptic modes of thought themselves, then at least to the problems in human existence from which they derive their meaning. ${ }^{53}$ In The First Man this confusion is eliminated, yet the significance of the account that replaces it is easily overlooked because of the subtly of its expression and its freedom from the apocalyptic structures that we now tend to take as paradigmatic of all meaningful speech about these experiences. In The First Man Camus' account is so quietly commonsensical we have to be careful that we do not miss it. The general emotional and intellectual climate of the book is one of a deep and sane humanity and a 
Ph.D. Thesis - R. Srigley McMaster - Religious Studies generous but un-blinkered moral clarity. Yet as apparent as that humanity and clarity are to the reader they still require some unpacking.

Jacques' account of his visit to the hospital is written from the point of view of a fourteen-year old boy and therefore belies the normal types of immaturity that one expects from a child that age. The other thing to keep in mind is that Jacques is not speaking about his own suffering, so his clarity or objectivity may be greater than what we might otherwise expect. Had Camus completed the book to the point when Jacques reaches the age of seventeen we would likely have known his response to that problem. Seventeen is the age when Camus himself suffered his first serious bout of tuberculosis. ${ }^{54}$ These qualifications notwithstanding there is real insight in what Jacques' says about the way we experience human suffering that goes some way to clarifying and healing our apocalyptic excesses.

The most obvious thing about the account is that there is no excessive lamentation about the misfortune of the veterans and no panegyric to the irreparable nature of human suffering. This descriptive moderation is apparent throughout the book but it is particularly evident in the episode with the veterans. Lamentation is of course a fitting human response to suffering and misfortune. According to Socrates in the Republic it is something that human beings desire by nature. ${ }^{55}$ Yet excessive preoccupation with suffering is neither salutary nor conducive to good judgement. Though it might be going too far to draw parallels between Jacques' reflections on the misfortune of the veterans 
Ph.D. Thesis - R. Srigley McMaster - Religious Studies and Socrates' declaration of the need for "deliberation" in the midst of our worst sufferings, there is nonetheless a remarkable similarity between the two accounts in terms of the patterns of response that they recommend. ${ }^{56}$ Though Jacques experiences compassion for the veterans, which is the active component of lamentation, he does not pity them and he does not feel overly sad for them. ${ }^{57}$ Instead he responds to their misfortune in the same way that he does to every other new experience he undergoes - he "immediately incorporate[s] it into [his] view of the world." Th8 be deliberation in the fullest sense, but it is something akin to it, and it is something that Jacques and his friends do naturally. The children do not judge "this world of cripples" to be sad. ${ }^{59}$ This is not because they are cold-hearted but because of what they see in the veterans themselves. Some are "closed-mouthed and somber," it is true..$^{60}$ But the majority play willingly and mischievously with the children and manage to cope with their infirmities in some way. This attempt to understand is evidence of the children practicing the kind of reflection that Socrates recommends as a means of responding to human suffering and of overcoming its worst temptations. Jacques recognizes these injuries as corruptions of the natural order of the human body. Indeed witnessing them makes him reflect on "the miraculous nature of the body's mechanics" in comparison. ${ }^{61}$ But that sober assessment is not the end of the matter. It encourages further reflection. Is this particular veteran's suffering bad? If so, how? And what might be done about it? These are the sorts of questions that are implicit in the responses of Jacques and his 
Ph.D. Thesis - R. Srigley McMaster - Religious Studies companions to their encounter with this world of suffering.

The experience also provides them with an opportunity to learn about one of the principal causes of these things, namely, war. Since Jacques has never experienced war first hand this bit of instruction offered by the soldiers and staff of the hospital is likely not equivalent to critical insight. But it does have its effect. It encourages in the children a certain realism about war and about the fact that it is an inescapable feature of life. ${ }^{62}$ As Jacques says, war, too, became "part of their universe" and therefore had to be accounted for in some way. No doubt the bulk of that accounting would come much later in life. Yet the start the children receive at the veterans hospital is a good one if they hope to gain a sense of the many faces of war and its terrible consequences. Moreover, the frankness of Jacques' response is the antithesis of modern ideological thinking about war in which utopian aspirations or ideas replace concrete observation as a means of establishing the truth of the matter. We may all wish that war were less frequent than it is, and that hope itself might help to diminish its likelihood in certain circumstances. But hope alone cannot abolish the dispositions of human nature out of which war and blood lust issue and a belief in the ultimately salutary effects of the conflicts authorized by a given ideology will inevitably obscure the real nature of its consequences in a way that Jacques' immature yet frank observations do not. Jacques himself expresses no such hope and possesses no ideology. The North African world in which he grew up offers neither. ${ }^{63}$ Yet his realism about the nature of war and its consequences promises a safer and more 
Ph.D. Thesis - R. Srigley McMaster - Religious Studies

reasonable world and a better understanding of the phenomena than those of his ideological rivals. $^{64}$

Jacques' realism is apparent in another of his responses to the veterans' injuries fear. ${ }^{65}$ After being struck by the extraordinary nature of the body it occurs to him that he too might be deprived of its wonders. Then "an unreasoning fear at the idea that he too might be mutilated" takes hold of him, though he soon forgets it. ${ }^{66}$ The easing of apocalyptic tensions is ultimately salutary but it also comes at a price. Human suffering may not be an eschatological event of everlasting moment, but it has its harsh aspects nonetheless and they must be faced honestly and directly. Violent mutilation is undesirable and Jacques is right to fear it. This is a normal human response. While hobbled briefly by a sprained ankle Jacques wonders about what life would be like without the ability to run and play freely ${ }^{67}$ The thought expresses a kind of compassion for the veterans at the same time that it provokes a fear about his own vulnerability. If war did this to the veterans and even worse to his father, what is to prevent it from happening to him? The compassion and the fear are reasonable responses. But so too is the fact that Jacques forgets both of them almost immediately. It may be childish disregard, or an expression of youth's almost infinite strength and irrepressible delight in the world. But interpreted in the broader context of the book it emphasizes that element of good judgement that knows how to have done with an experience once it has been understood and how to silence fear or grief for the sake of other, more important considerations. 
Ph.D. Thesis - R. Srigley McMaster - Religious Studies That, too, is a form of Socratic deliberation, albeit youthfully expressed.

I said at the outset of this discussion that it is difficult to know what is the most basic tension in The First Man, the one that Camus offers in place of the various apocalyptic formulations that he sought to overcome. There are a number of candidates. Nietzsche's distinction between the Apollinian principle of individuation and the Dionysian movement toward primal unity in The Birth of Tragedy is a possibility. It is consistent with the tragic nature of Jacques' account of greatness, but it is less effective at capturing his moral hesitations about those who aspire to $\mathrm{it}^{68}$ as well as his reservations about its opposite - poverty. ${ }^{69}$ Moreover it also tends to reintroduce the divine/human antithesis that Camus is attempting to supercede as the contradiction on which that aspiration rests. ${ }^{70}$ Martin Buber's distinction between $\mathrm{I} /$ Thou relationships and $\mathrm{I} / \mathrm{It}$ experiences is another plausible candidate. ${ }^{71}$ Camus was familiar with Buber's book and commented on it favourably in relation to his own work. ${ }^{72}$ Its influence can be seen in passages that at first glance might appear to support Nietzsche's interpretation but which seem closer to Buber's analysis upon further reflection. In these instances the individuation/primal unity formulation gives way to something more like Buber's distinction between the surface character of $\mathrm{I} / \mathrm{It}$ experiences and the encounter with substance afforded by I/Thou relationships. Camus claims that Jacques has two lives. The first is the "everyday surface of his outward life"; the second is one whose "history would 
Ph.D. Thesis - R. Srigley McMaster - Religious Studies be told as a series of obscure yearnings and powerful indescribable sensations," from the fragrance of "jasmine and honeysuckle in the upper neighborhoods" to the warmth of a woman's body.$^{73}$ Like I/Thou relationships, the various encounters that make up Jacques' "second life" always occur in relation to particular things, never in abstraction from them. Yet they also put him in contact with a world that is somehow boundless or unrestricted by any phenomenal reality. ${ }^{74}$ This too is consistent with Buber's account.

It may be that both accounts influenced Camus in some measure and that traces of them can be found in his work. But I think there is good textual evidence to suggest the influence of another source in the construction of The First Man that played an even greater role than either of these two - Plato's Symposium. First the prima facie evidence. Camus was certainly familiar with the Symposium as well as with other Platonic dialogues. He acquired this familiarity in a number of ways - from his research for Christian Metaphysics and Neoplatonism, from his study of Brice Parain's work on Plato, and through his own mature readings of the dialogues. ${ }^{75}$ It is true that there is no sustained analysis of Plato in Camus' books. The most Plato gets is a brief allusion here or there. Yet he is never far from Camus' mind. And when such allusions do occur they are highly favourable and most often of some importance for the argument Camus is making. Usually they point to the folly of modernity or the illusory nature of the goods it offers and indicate the depth and sanity of the ancient world Plato represents by comparison. ${ }^{76}$ The other piece of prima facie evidence is apparent in the structure of the cyclical 
Ph.D. Thesis - R. Srigley McMaster - Religious Studies books. The planned theme of the third cycle of books was to be love or eros. ${ }^{77}$ We know that this cycle was to involve a return to the Greeks and an attempt to determine what had been lost in the transition from Hellenism to Christianity. ${ }^{78}$ At the confluence of these ambitions love in the Greek sense emerges as the most obvious candidate for what has been lost in the West as a result of the advent of Christianity. And if this insight is coupled with Camus' abiding preference for Plato, then the Symposium begins to appear as the obvious place he would look in order to find and then elucidate a Greek understanding of love. In addition to this prima facie evidence there is also textual evidence in The First Man that attests to Camus' use of the Symposium in both its thematic organization and construction. I will discuss the thematic parallels first, and then turn to the details of the text's construction.

The movement between poverty and abundance that Camus describes in his first books and that he promised would be a central theme of his third novel is indeed apparent in The First Man. ${ }^{79}$ The poles of that movement are understood and configured in a number of different ways. First of all there is the trajectory of Jacques' own life, in which he moves from economic and cultural poverty to extraordinary riches of both types. ${ }^{80}$ While we might be tempted to think of this movement as one of straightforward improvement, it is not. Jacques is extremely successful by any measure, yet he is no apologist for bourgeois capital. It is therefore not surprising to find him having trouble putting together these different worlds in the middle period of his life. At one moment he 
Ph.D. Thesis - R. Srigley McMaster - Religious Studies declares his preference for the sparseness and anonymity of poverty, and at the next he declares the impossibility of enduring such a life in comparison to the fullness of the one he has lived ${ }^{81}$ This awkward shuffling back and forth between the relative merits of poverty and abundance continues for much of the story without ever being adequately resolved or even understood. I think it would have been resolved had Camus managed to complete the text, though not in the manner of either capitalism or socialism. Rather I believe that the way in which Camus might have approached the problem is indicated in part through a comparison with his source text - the Symposium. But first a few more words about other configurations of the themes of poverty and abundance in the text. It is Jacques who most clearly embodies the movement between poverty and abundance in the story though that movement is also apparent in other characters. However that is not the only meaning that the terms have in the analysis. They are also associated individually with specific characters. Georges Didier personifies wealth, as do several others of his class, though the rich are not plentiful in this portion of the manuscript; and there is of course a large cast of characters who exemplify poverty Uncle Ernest, Pierre and his family, Daniel. In both of these cases the association carries with it little dramatic weight. When it comes to Jacques' parents it is otherwise. Jacques' mother, Catherine Cormery, is so closely associated with poverty that she emerges as a symbol of that condition in the economy of the narrative. When Jacques loses his bearings and forgets the lessons of poverty it is always to his mother and the truth she 
Ph.D. Thesis - R. Srigley McMaster - Religious Studies represents that he turns in order to regain them. Camus' notes for the novel make it clear that this symbolism was intentional ${ }^{82}$ and would have been worked out in detail in the third part of the novel. ${ }^{83}$

Henri Cormery occupies a similarly important place in the symbolism of the novel. But it is not poverty that he represents, though when we first meet him he is as poor as his wife. ${ }^{84}$ Despite this similar circumstance Henri embodies the disposition or state opposite to the one represented by Catherine Cormery - abundance. Not in the sense of what he has achieved, however. Henri lives only to the age of twenty-nine and his accomplishments, though not negligible, are limited. ${ }^{85}$ Jacques' most common way of reflecting on the nature of his life is to associate him with the French colonists of 1849 who were the first modern Europeans to settle in Algeria. ${ }^{86}$ That group was not rich either, but their voyage to Africa carried with it both the promise of wealth and the resourcefulness necessary to bring it about. ${ }^{87}$ There is a criticism of the politics of colonialism in Jacques' reflections on this group.$^{88}$ But there is also admiration and pity for these tough and determined people who soon find out that their own histories, for better and worse, are inexorably mixed up with the history of this beautiful but unforgiving land..$^{89}$ According to Jacques Henri is like them and shares their resourcefulness. Only twice in the story do we meet Henri in real time and on both occasions he proves to be equal to the difficult circumstances in which he finds himself. ${ }^{90}$ Despite the extraordinary hardships his family faces Henri manages to provide for them, 
$\mathrm{Ph} . \mathrm{D}$. Thesis - R. Srigley McMaster - Religious Studies

even after his death..$^{91}$ And when he is finally defeated it will be due not to a personal failing but a shell fragment through his skull.

There is one final use of the terms poverty and abundance in The First Man. In addition to their descriptions of different dispensations of Jacques' life and their identification with specific characters in the story, Camus complicates their usage by also having them denote different existential dispositions that are found in all characters independently of their social class. The economic analysis is sublimated into one in which poverty and wealth are judged by standards of value other than those recognized and employed by economic theorists of both the left and the right. ${ }^{92}$ The relative affluence of the bourgeois world Jacques encounters in the office is to him utter destitution in comparison to the material and existential riches he enjoys in the far poorer world Belcourt. ${ }^{93}$ These types of meaning are also implied in the other two usages of the terms, certainly. But here they are broadened out to encompass and illuminate the nature of human life per se. The descriptions of poverty and resource that Camus develops through accounts of Jacques' and his father's lives never remain purely individual; nor do they denote conditions that are exclusive to those raised in North Africa. Rather they become part of a broader account though which Camus is able to explore the tensions and movements of human nature itself. And here as in his description of Jacques' life, sorting out the relationship between them gives Camus some trouble. How to describe these things? What is truer, poverty or abundance? And how should one live given this 
Ph.D. Thesis - R. Srigley McMaster - Religious Studies

structure of life?

In the 1958 Preface to The Wrong Side and the Right Side in which Camus announces and anticipates the themes and concerns he wished to explore in his next cycle of books, he explains the matter in a way that this problematic character disappears, though not the tension and the terms of the tension themselves. In this text he claims to feel humility "only in the presence of the poorest lives or the greatest adventures of the mind. Between the two is a society [he finds] ludicrous."94 In this formulation poverty and wealth, the high and the low are not opposed but share a similar nature or insight into the character of life that unites them. This is particularly apparent when they are compared to what lies between them - a bourgeois society that Camus claims is ludicrous. The poor, whether in spirit or materially, are closer to what is real because they have little to shield them from its worst aspects as from its best. This closeness to real things is also apparent in those who undertake great adventures of the mind. They dispense with the comforts and self-satisfaction of bourgeois life in order to pursue the highest things. This does not mean that the adventurers of the mind experience only what is noble and beautiful while the poor encounter only what is ugly and harsh. Though there is some truth to this notion, it would be false to accept it uncritically and without qualification. For Camus both aspects of life are available to the poor and the great alike. Here as in The First Man what brings them together is a common need and a shared disposition to see things as they are. The noble and the beautiful, the ugly and the tragic - these are the stuff of life for all 
Ph.D. Thesis - R. Srigley McMaster - Religious Studies human beings. Poverty and resourcefulness denote the nature of human reality, regardless of age, economic station, or even ability. But what has all this to do with the Symposium?

The analysis of human nature that Camus develops by means of these images matches the analysis of eros in the Symposium in both its content and its genealogy. It is difficult to say whether Camus was working with the Symposium directly when he was writing The First Man, or whether its influence on the composition of the text was more indirect and atmospheric. Whichever the case the parallels between the two books are significant and therefore require some explanation. The following analysis reflects what I have been able to understand about them.

First the genealogical parallels. In the Symposium Socrates/Diotima teaches us that eros is the son of Poros (resource) and Penia (poverty).

When Aphrodite was born, all the other gods as well as Poros [Resource] the son of Metis [Intelligence] were at a feast; and when they had dined, Penia [Poverty] arrived to beg for something - as might be expected at a festivity - and she hung about near the door. Then Poros got drunk on nectar - for there was not yet wine and, heavy of head, went into the garden of Zeus and slept. Then Penia, who because of her own lack of resources was plotting to have a child made out of Poros, reclined beside him and conceived Eros. ${ }^{95}$

The three-part structure of The First Man repeats the triad of Poros, Penia, and Eros of the Symposium's genealogy both in form and content. Catherine Cormery is poverty, Henri resource, and their child, Jacques, is eros. The point of the book is to explore the dual character of eros through an analysis of Jacques' life in relation to the existential poverty and resourcefulness symbolized by his parents. The two texts also match in terms 
Ph.D. Thesis - R. Srigley McMaster - Religious Studies of their assessment of the importance of eros for human life. In the Symposium Socrates claims to "have expert knowledge of nothing but erotics"; 96 in The First Man Camus planned to speak of "a certain form of love" and to explore the full amplitude of human nature by means of its erotic movements. ${ }^{97}$

The Symposium analysis, had he managed to complete it, would have helped Camus to overcome his occasional worry about the apparent antithesis between poverty and resource that he sometimes struggles with in The First Man. Ever since Augustine's reworking of the anthropology of the Symposium in book seven of the Confessions ${ }^{98}$ and his recasting of eros' unity into two distinct types of love - human and divine - in The City of God, ${ }^{99}$ these sorts of confusions have carried the day. But they do not exist in the Symposium itself. The dispositions or states denoted by these terms are not opposed in the Christian sense, as troubling as their coexistence may sometimes be. Indeed the text does everything it can to undermine such a supposition. ${ }^{100}$ The high and the low, poverty and resource, are bound together in eros and in a human nature that we all share. We are all like Penia in one sense - uninvited nobodies attempting to bamboozle our way into the party. But we are also like Poros - we have resources, too, and so there are reasons why perhaps the door should be opened to us. Both are permanent features of human nature, apparent in the richest souls as in the poorest, and both are inescapable.

In addition to this general structure of the text there is a particular episode in The First Man that follows the analysis of the Symposium as a template for its construction. 
Ph.D. Thesis - R. Srigley McMaster - Religious Studies Here too the question of whether Camus was working with the Symposium directly remains open. But there are a sufficient number of parallels between the two texts at least to suggest a positive answer. The episode in question occurs during Jacques' celebration of his First Communion and the subsequent festivities that have been arranged by his family. ${ }^{101}$ The first scene takes place in the Church where Jacques and his fellow initiates are studying the catechism. The method of instruction is recitation and the "spiritual training" the boys receive is entirely orthodox. The problem is that it is also entirely empty because the words it employs "meant absolutely nothing to the young catechumens."102

The catechism and the priest's instruction are a restatement of Agathon's speech in the Symposium. Jacques' response to it is a repetition of Socrates' critical assessment of Agathon's account. Like the catechism itself Agathon's speech is orthodox in the precise sense. It repeats popular opinion but without attempting to improve it or educate those who hold it. ${ }^{103}$ That does not make it as traditionally religious or repetitious as the priest's instruction. Nonetheless it suffers from a similar problem. After having his idea of love refuted by Socrates, Agathon admits that "it's probable, Socrates, that I knew nothing of what I had said." Socrates' reply is telling: "And yet you spoke beautifully, Agathon."104 Jacques response to the priest's instruction restates Socrates' criticism of Agathon. The things Jacques experiences as a catechumen makes him dream "richer, deeper dreams featuring sacerdotal objects and vestments glistening in the semi- 
Ph.D. Thesis - R. Srigley McMaster - Religious Studies darkness" - that is to say, religious objects or artifacts. ${ }^{105}$ These things are beautiful, particularly in comparison to the rougher world of Belcourt to which Jacques compares them. But he also knows that they are somehow empty. The contrast between the two worlds parallels Socrates' response to Agathon's request to share his wisdom when he first arrives at the symposium. Socrates says (ironically) that in comparison to Agathon's wisdom, which is "brilliant and capable of much development, since it has flashed out so intensely from [him] while [he is] young," his own "may turn out to be a sorry sort of wisdom, or disputable like a dream." 106 The beautiful but dream-like quality of what the priest offers and the relative sparseness of Jacques life by comparison is a re-enactment of this exchange between Socrates and Agathon. Jacques' wisdom, like the poverty of his life, is a sorrier sort of thing than the beauty of the priest's religion and the wonders of the church. But it is truer nonetheless, just as Socrates' wisdom is truer than Agathon's beautiful but empty rhetoric about love.

The priest and Agathon are matched throughout this sequence in the text. There is even a similar violence in both accounts. In The First Man the priest strikes Jacques across the face, mistakenly thinking that he had made fun of him. ${ }^{107}$ Jacques takes the blow without crying and without cowering, but for the sake of the order of things arranged by his family he consents to continue with his religious instruction. But he must do so tongue in cheek, as it were, in order to stanch the bleeding caused by the blow. ${ }^{108}$ This matches the scene in the Symposium perfectly. Socrates, too, describes a threat of 
$\mathrm{Ph} . \mathrm{D}$. Thesis - R. Srigley McMaster - Religious Studies violence - from Agathon. He likens his speech to the head of the Gorgon, which Agathon sends against him in order to "turn [him] to very stone in speechlessness."109 Two threats of violence, both of which are motivated by a desire to silence a perceived impertinence. Agathon thinks that Socrates is having a joke at his expense, just as the priest thinks Jacques is mocking him and his authority. What else is Jacques' "tongue in cheek" response to the priest's instruction but an playful expression of Socrates' ironic assessment of the merits of Agathon's eulogy? ${ }^{110}$

Another parallel between the two texts is apparent in the conversation that occurs between Agathon and Socrates following the former's speech and in Diotima's initial discussion with Socrates about various possible confusions concerning the nature of eros. Aspects of these conversations are reworked in Jacques' assessment of his religious instruction and his response to the party that he encounters when he returns home after receiving Communion. These parallels deepen Camus' substantial analysis of the nature of eros and clarify the inadequacies of the Christian account in comparison. In the prelude to his own speech Socrates tells us that prior to meeting Diotima he was confused about the nature of eros in much the same way that Agathon is. ${ }^{111}$ Like Agathon his confusion is due to his acceptance of a number of false dichotomies that cause him to simplify the nature of eros in a way that obfuscates its true character. The dichotomies are well known to us. If eros is not beautiful, then he must be ugly; if he is not immortal, then he must be mortal; if he is not divine, then he must be human. ${ }^{12}$ What Diotima teaches Socrates is 
Ph.D. Thesis - R. Srigley McMaster - Religious Studies that these false oppositions distort our understanding of eros by creating an illusion of comprehensiveness that compels us to conceive of it as occupying one or the other poles of the opposition exclusively. As Diotima says, “"do not compel what is not beautiful to be ugly, or what is not good to be bad... [S]ince you yourself agree that Eros is not good or beautiful, do not at all believe that he must be ugly and bad...but something between the two of them'."113 After disabusing Socrates of these false oppositions, Diotima goes on to instruct him in both the imperfect and perfect revelations concerning eros. ${ }^{114}$

The manner in which Camus recasts these insights in The First Man is straightforward and compelling. He exemplifies and illuminates the false oppositions between mortal and immortal, divine and human through Jacques' experiences in the Church. The setting expresses the content of Camus' insight perfectly. For Camus the Church is the place in the modern world where the distinction between divine and human, mortal and immortal is most scrupulously maintained. ${ }^{115}$ This is the Christian confusion. It fragments our experience of reality generally and of eros particularly in ways that leave us wondering whether there is any meaning in the world at all; and when we adhere to the teaching stridently it encourages our worst apocalyptic excesses. Jacques' response to the teaching is clear - he finds it empty. And though he does experience a kind of mystery while attending the mass, he tells us that "it was a nameless mystery where the divine personages named and rigorously defined in the catechism played no role at all." ${ }^{116}$ Like the false oppositions of the Symposium these highly differentiated religious divinities 
Ph.D. Thesis - R. Srigley McMaster - Religious Studies obfuscate or distort our experience of the world's mystery. And also like the Symposium they are entirely unerotic. They are as cold as the priest who strikes him and have nothing to do with the "warm, inward, and ambiguous mystery" that bathes him and that only deepens the "everyday mystery of his mother's silence or her small smile." ${ }^{117}$ Instead Jacques claims that these religious divinities "were simply an extension of the bare world where he lived." 118 They do not express the type of poverty that Jacques associates with his mother and thus with the deep love he feels for her, but rather with poverty's worse aspects - its destitution or emptiness.

Already during the mass and then after he returns home Jacques begins to feel more ordered. Indeed he experiences a kind of exaltation that takes "him away from everything that was happening" around him, including the instant of Communion. ${ }^{119} \mathrm{He}$ feels his "strength" and his "boundless ability to prevail and to live" grow within him. ${ }^{120}$ However when his exaltation subsides he finds himself troubled by two different things. The first is the gaiety and excitement caused by the relative opulence of the Communion celebrations organized by his family. These are false riches that pale in comparison to the true riches he has just experienced - just another false divinity to overcome, this time the material affluence of the bourgeois. But the thing that troubles Jacques the most is his mother. As Jacques makes clear earlier in the account her "small sad smile" is an expression of that deeper mystery in which his exaltation or abundance is held together with her poverty in a movement that is simultaneously beautiful and heartbreaking, and in 
Ph.D. Thesis - R. Srigley McMaster - Religious Studies any case something quite different from the festivities going on around them.

Here as throughout the narrative Catherine Cormery is Penia. She may not have crashed the party as Penia did in the Symposium, ${ }^{121}$ but like her she is poor and needy and desirous of something the other guests seem to ignore. Jacques - Eros - is her son and has inherited her neediness. When he finally catches a glimpse of her he recognizes immediately her poverty and is reminded that he too is like her, despite the strength and resourcefulness he feels growing within him. But there is something else. Where is Poros? Henri Cormery is dead and therefore not at the celebration. Whom is Penia to seduce? Her son? Though there is a strong attachment between Jacques and his mother there is nothing Freudian about the relationship. ${ }^{122}$ What other meaning might we assign to Poros' absence? This might be Camus' comment on the nature of our current historical dispensation. Are we moderns erotic in our neediness but lacking eros' resourcefulness and ability? If that were true, then one might say that the situation has been reversed in our time. Our current technological society seems to be resourceful beyond measure but bereft of the deep longings or poverty of love that gives shape to our aspirations and is the measure of their achievement. In the age of ideologies that poverty might still have been a lived reality, no matter how confused its expression or how cluttered over with false satisfactions and ambitions it may have been. But what are we to make of today's selfsatisfaction and indifference? The material, emotional, and intellectual security or perfection sought for by modernity requires the elimination of eros with its nagging needs 
Ph.D. Thesis - R. Srigley McMaster - Religious Studies as well as its playful resourcefulness. This destruction of eros is not without its consequences. The price of that achievement is the indifference and empty efficiency of the world in which we now live. ${ }^{123}$ I think Camus would argue that we deceive ourselves if we believe we can retain the excitement or meaning associated with eros while also satisfying our most extreme utopian ambitions. "A loveless world is a dead world" says Rieux in The Plague. ${ }^{124}$ Whatever renewal of life is possible in such a world it will not be achieved without abandoning the causes of death that Camus here identifies.

The final reference to the Symposium apparent in this episode of The First Man occurs immediately after the events of the Communion celebration. In the Symposium, after her initial clarification of the nature of eros Diotima continues by attempting to instruct Socrates in the "perfect revelations." 125 Something similar happens to Jacques after he is reminded of the mystery in which both he and his mother participate. After overcoming the confusions of the religious rituals he is forced to undergo, Jacques spends the next few days hard at work on "his last lessons" with M. Bernard. ${ }^{126}$ These lessons are preparation for his entrance exams for the Lycée, that is to say, the academy - Plato's school. Though the imagery is a little clumsy, the meaning is consistent with that of the Symposium. After Jacques leaves the Church with its false dichotomies and distortions, and after his first initiation into the mysteries of life, he turns to the teachings of Plato to learn the "perfect revelations" about eros. The content of what he learns is never worked out in detail. The manuscript remains incomplete in this regard. But there is at least a 
Ph.D. Thesis - R. Srigley McMaster - Religious Studies suggestion of that content that is also consistent with the analysis of the Symposium.

After teaching Socrates about the deeds of eros - bringing to birth in the beautiful in both body and soul - Diotima tells him that what is most "appropriate for the soul to conceive and bear" is "prudence and the rest of virtue."127 Though all the virtues are desirable, her account indicates that prudence is the greatest of them all; and she teaches Socrates that "the greatest and most beautiful part" of the greatest and most beautiful part "is the arranging and ordering of the affairs of cities and households." ${ }^{128}$ In The First Man Jacques' initial youthful introduction to the mysteries of eros is followed immediately by a chronological leap in the narrative through which we encounter him some thirty years later engaged in a conversation about politics with another French North African named Veillard. ${ }^{129}$ Veillard has deep roots in Algeria and has decided to stay regardless of the outcome of the war. His view of politics is harsh but realistic. He playfully derides the idealism of the settlers who first came to Algeria. They were the ones who made the revolution of 1848. Veillard says of them that "they were the kind who believed in Santa Claus. And their Santa Claus wore a burnoose." ${ }^{n 130}$ The reality of the settlements were of course vastly more brutal than anything they had imagined and certainly more brutal than the revolution itself. Between raids by Arabs bands and other French settlers, attacks by lions and Kabyle dogs, and an epidemic of cholera fully two-thirds of the original thousand or more settlers were dead within three years. ${ }^{131}$

Jacques clearly feels at home with this frank-speaking fellow North African but he 
Ph.D. Thesis - R. Srigley McMaster - Religious Studies also has hesitations about his politics. After Veillard's account of the current war "We'll kill each other for a while longer, cut off each other's balls and torture each other a bit. And then we'll go back to living as men together. The country wants it that way" he offers Jacques another anisette. Jacques reply is important. He says "Light."132 Jacques' reticence might mean that Veillard is drunk and that his politics too expresses a kind of intoxication or excess regarding the need for power and violence. Or is it the reverse? In an age of ideologies his harsh but ultimately moral assessment of the conflict is too light - too optimistic. There is some truth in both interpretations. Maybe a combination of them will capture Camus' meaning.

Jacques is willing to drink with Veillard, but he does not want to drink as much and he does. What does this mean? We know from his other books that Camus did not approve of the use of torture and mutilation as a technique of war. ${ }^{133}$ In addition to being repugnant to our humanity such tactics only serve to swell the ranks of the enemy. ${ }^{134}$ So what is it in Veillard's account of politics that Jacques/Camus might approve and that is consistent with the teaching of the Symposium? Nothing simple, that is certain. But here is a guess. I think it has something to do with Veillard's claim that the only people other than the French settlers to understand the true nature of the conflict in Algeria are the Arabs. As Veillard states, "we were made to understand each other." madness in the violence between them, certainly. But as bad as it is it is real violence; and it occurs between "men." 136 This is something closer to Martin Buber's I and Thou than it 
Ph.D. Thesis - R. Srigley McMaster - Religious Studies is to Machiavelli's Prince. Buber claims that it is possible to have an I/Thou relationship with an enemy. ${ }^{137}$ You can truly encounter the substance or meaning of another even in open hostilities. Not so in the case of modern ideological thinking. The ideological warfare endorsed by those in Paris and Moscow is far more dangerous than the real violence of those fighting on the ground. ${ }^{138}$ Veillard despises the former with their ideologies and politics and their abstraction from the real conflict and its causes. Their type of thinking has made violence and war a permanent condition rather than a temporary disruption of order to be solved through the reconciliation of real interests. ${ }^{139}$ In Veillard's account of the situation the war is a temporary condition. The two parties or sides find themselves in conflict with one another and so they fight. When hostilities have ended and some kind of existential balance has been restored they will make peace and go back to "living as men together." This is where Veillard might be too optimistic. Stability and peace are not the outcomes desired by ideological thinkers. For them politics has grander ambitions that are not satisfied with such partial solutions. Unfortunately for Algeria they were the ones to prevail in the conflict historically. Their approach to the problem has succeeded only in driving the country into over forty years of sectarian violence that has almost entirely destroyed its civil society.

In terms of content there is no one to one correspondence between these reflections on politics and what Socrates says in the Symposium. It may be that Jacques wants to soften the excesses of Veillard's account in much the same way that Socrates is 
Ph.D. Thesis - R. Srigley McMaster - Religious Studies reported to have attempted to teach Alcibiades about the nature of both eros and politics in the Symposium. But because the final two sections of The First Man were never written we simply do not know the full content of the politics Camus might have offered in the book.

In The First Man the religious notion of God or transcendence vanishes from the account as a problematic. This is in part due to Jacques' awareness of the artificial nature of the religious doctrines that encourage that problematic. During his brief stint as a catechumen he has occasion to experience the "divine personages" of the Church iconography, as we have seen. In Jacques' assessment of the problem with those personages is not that they are divine but that they are not divine enough. The claim is similar to Nietzsche's insight in Untimely Meditations that Christianity precipitated a dedivinization of reality in comparison to "the much more religiously inclined world of antiquity. ${ }^{140}$ For Jacques the Christian divinities are merely an extension of the bare or empty life of Belcourt and do not reflect the deeper mystery he senses in himself and in his mother. ${ }^{141}$

The Christian iconography encourages an existential emptiness that matches the emptiness Jacques senses in its symbolization. One expression of that existential emptiness can be found in its apocalyptic claim that life itself is a problem. The emphasis on narrative or drama notwithstanding, it is the Christian doctrine of the fall and its 
Ph.D. Thesis - R. Srigley McMaster - Religious Studies manner of separating the divine and the human that encourages this type of sentiment in existence. ${ }^{142}$ For Jacques it is otherwise. He never describes life as a problem no matter how difficult its suffering may be; and the mystery he experiences is never presented as a solution to a problem. The mystery is not a place; nor is it a thing. It is hard to know how to speak of it at all, and Jacques himself stumbles somewhat in doing so. ${ }^{143}$ Perhaps we can say that it is an index of one's participation in life that expresses neither a subjective state nor a objective condition. Or perhaps it is eros. This would be consistent with another passage from the Symposium in which Socrates gives eros primacy of place by asserting it is what binds the whole itself together. ${ }^{144}$ Here eros is taken to be an even more fundamental reality than the things between which it mediates, including gods and mortals. In this view the world begins to emerge as an order of love that is best understood by exploring its erotic movements. Whatever the case may be the freedom from the Christian problematic that such insights entail is apparent on almost every page of The First Man. It is also an experience or disposition that Camus describes explicitly in another place. "Poverty kept me from thinking that all was well under the sun and in history; the sun taught me that history was not everything. I wanted to change lives, yes, but not the world which I worshipped as divine."145 Living in this tension or movement is life and the meaning of life.

The mystery that Jacques experiences is expressed through a number of different images in The First Man. The structure of these images is instructive. They are all drawn 
Ph.D. Thesis - R. Srigley McMaster - Religious Studies from the things and events that make up everyday life and they all express a duality in Jacques' experience of them. What is most telling about the account is that the things he uses to express his experience of the mysterious order of life are the same as those he uses to describe its surface or everyday character. Here is a list of the things that make up the latter: "that style, those games, that daring, that ardor, the family, the kerosene lamp and the dark stairs, the palms in the wind, birth and baptism in the sea, and finally those gloomy laborious summers." 146 Here is a list of what constitutes the former: "obscure yearnings and powerful indescribable sensations, the order of the schools, of the neighborhood stables, of laundry on his mother's hands, of jasmine and honeysuckle in the upper neighborhoods, of the pages of the dictionary and the books he devoured" and "the immense sea before him, and behind him the endless expanse of mountains, plains, and desert called the interior."147 There are differences in detail in the two accounts, but the range and types of things they describe are the exactly the same. In both instances it is just the normal stuff of life. What does this mean?

The first thing it means is that whatever this mystery may be, it is not transcendent in the spatial sense but a reality that is present in all things, from the greatest to the least. It is not a gnostic divinity that must be achieved because it is unavailable or inaccessible. The mystery Jacques experiences and describes is not Heidegger's Being or Christianity's God. Rather it is a dimension of reality in which we all participate by nature and that is present or apparent in things at all times. In a richer expression of the same insight Camus 
Ph.D. Thesis - R. Srigley McMaster - Religious Studies writes: "What meaning do words like future, improvement, good job have here? What is meant by the heart's progress? If I obstinately refuse all the 'later ons' of the world, it is because I have no desire to give up my present wealth."148 Of course one has to think about what will come sooner or later, and Camus himself offers a vivid account of how to do so in another early essay, "The Desert."149 But the point is that one can do so meaningfully only and precisely because the order of the cosmos and one's participation in it remain constant. To use an earlier formulation we might say that life is not a problem.

If life is not a problem then neither is death. The latter insight is companion to the former, yet it is one to which Camus seems to have been slower in coming. The passage from Hölderlin cited in the epigraph to The Rebel suggests that Camus had already understood and overcome the fear and rebellion that death can provoke. ${ }^{150}$ Indeed that overcoming is one of the central tasks of the book. Yet over the course of the analysis both experiences occasionally insinuate themselves back into the text in a way that undermines its main argument in some measure. ${ }^{151}$ In The First Man Camus seems finally to have achieved some clarity and resolution about the matter. There is still a hint of the old rebellion in the scene in the cemetery when he reflects on the injustice of his father's death and of those of the other young men buried there. ${ }^{152}$ And it crops up again in the final pages of the manuscript, if only as an experience he hopes finally to overcome. ${ }^{153}$ But in the few other instances in the book when he speaks about death there is no trace of 
Ph.D. Thesis - R. Srigley McMaster - Religious Studies the former rebellion or even of any great existential disturbance. What changed?

Two things seem to have become clear for Camus. The first concerns the type of politics to which the fear of death can lead. The fear of death is an expression of self-love, and this self-love taken to its extreme results in the types of violent apocalyptic politics that characterize the modern world. This is the argument of The Fall. Any human disposition that leads to that level of destruction has failed or is unwilling to face up to some aspect of reality. The second insight is the same as the first only formulated positively. The more one enters into the erotic movements of life, both for better and for worse, the less one fears death. Camus does not say this in so many words, but it is an insight that is apparent in the very nature of the narrative of The First Man. The more you love the world the more you understand it; and the more you understand it the more you recognize your limited share in existence. As Jacques reflects on the generations of men and women who have lived and died on his native North African soil he calms down and almost takes delight in the fact that one day he too will return to its "immense oblivion." 154 Like the lover he describes in the closing pages of the manuscript, at times Jacques too wants to "flee to a country where no one would grow old or die, where beauty was imperishable, where life would always be wild and radiant." "55 But he always comes back to his senses and acknowledges the truth of the matter. Such a place does "not exist."156 This frank realism is a necessary step to achieving a meaningful relationship to death and indeed to all things. It is also an expression of deep love for the world. Despite 
Ph.D. Thesis - R. Srigley McMaster - Religious Studies what one is told the hope for another life is tantamount to oblivion from this one. And the often pious exterior of that hope notwithstanding, it is also an extreme form of self-love. Rather than feed such hopes, Camus seeks to quiet them. The diminution of self-love may be painful, but it also carries with it a promise: "The only one who renounces his self, his $\mathrm{I}$, is the one who accepts whatever happens with its consequences. Then one is in direct contact." ${ }^{\prime 157}$ This desire for direct contact is a constant theme in Camus' books. Here as in his earliest works it is not so much argued for as demonstrated. But whatever its form, it always stands opposed to the various mediators who seek to govern our world and whose glittering promises of another life have succeeded only in depriving us of the one we have. 
Ph.D. Thesis - R. Srigley McMaster - Religious Studies

Notes

1. See Catherine Camus' Editor's Note for the English translation of the book. Albert Camus, The First Man, trans. David Hapgood (New York: Alfred A. Knopf Canada, 1995), v-vii.

2. The ambiguity is created by the fact the Part divisions in the extant manuscript do not correspond exactly to the organization described in Camus' notes. Ibid., 308-309.

3. Ibid.

4. Ibid., 1.

5. "I merely wanted to show that if I have come a long way since this book, I have not made much progress. Often, when I thought I was moving forward, I was losing ground. But, in the end, my needs, my errors, and my fidelities have always brought me back to the ancient path I began to explore in The Wrong Side and the Right Side, whose traces are visible in everything done since, and along which on certain mornings in Algiers, for example, I still walk with the same slight intoxication." Ibid., 14-15. This relationship is a matter that I discuss in greater detail in the conclusion of this work.

6. See, for example, the rhetoric of Callicles in Plato's Gorgias. Plato, Gorgias, trans. James H. Nichols Jr. (Ithaca: Cornell University Press, 1998).

7. "Confronting...in the oldest story in the world we are the first men - not men on the wane as they shout in the [] newspaper but men of a different and undefined dawn." The passage contains both a critique of Augustine's saeculum senescens and nod to Nietzsche's ambition. Albert Camus, The First Man, 319.

8. This was something of a programmatic declaration for Camus. "Free oneself from any concern with art. Regain direct contact, without intermediary, thus innocence." Ibid., 303.

9. Ibid., 23-24.

10. Ibid., 61 .

11. Ibid., 80.

12. Ibid., 193-194.

13. Ibid., 61-75. 


\section{Ph.D. Thesis - R. Srigley McMaster - Religious Studies}

14. Ibid., 193.

15. Ibid., 238-240.

16. I discuss this notion below.

17. Ibid., 209.

18. "They taught him more about the young dead man of Saint Brieuc than the [senile] and disordered recollections that he had gone to seek." Ibid., 187.

19. "But [Jacques] was stupefied by the noise, it plunged him into a nasty sort of torpor where he tried in vain to evoke his father, to imagine him, but he disappeared behind this immense and hostile land, he melted into the anonymous history of the village and the plain." Ibid., 186.

20. Ibid., 195.

21. For a discussion of Augustine's teaching, see Eric Voegelin, Order and History Volume 4: The Ecumenic Age (Baton Rouge: Louisiana State University Press, 1974), 266-271. For a discussion of the end of history, see Francis Fukuyama, The End of History and the Last Man (New York: Perennial, 2002).

22. Albert Camus, The Rebel, 190.

23. See Eric Voegelin, The New Science of Politics, 107-127.

24. One gets the sense that nothingness is relished in the works of Sartre. See, for instance, a book like Nausea. The desire to overcome the experience is more characteristic of the work of Kierkegaard. The Concept of Anxiety is a case in point.

25. "The world is never quiet; even its silence eternally resounds with the same notes, in vibrations that escape our ears. As for those we perceive, they carry sounds to us, occasionally a chord, never a melody." Albert Camus, The Rebel, 256. As to such modern ideologies, Sartre's existentialism is a case in point, though perhaps not the most interesting one. Jean-Paul Sartre, Existentialism and Humanism, trans. Philip Mairet, (Brooklyn: Haskell House Publishers Ltd., 1977). As Camus argues in The Rebel, all progressivist historiographies - Marxist, positivist, Christian - silence nature in some way. Albert Camus, The Rebel, 188-245. 
Ph.D. Thesis - R. Srigley McMaster - Religious Studies

26. Albert Camus, The First Man, 245-ff.

27. "The Mediterranean separates two worlds in me, one where memories and names are preserved in measured spaces, the other where the wind and sand erases all trace of men on the open ranges." Ibid., 196.

28. "I do not want to choose between the right and wrong sides of the world, and I do not like a choice to be made." Albert Camus, The Wrong Side and the Right Side in Lyrical and Critical Essays, 61.

29. Ibid., 60.

30. Ibid., 49.

31. "The great courage is still to gaze as squarely at the light as at death. Besides, how can I define the link that leads from this all-consuming love of life to this secret despair?" Ibid., 61 .

32. Albert Camus, The First Man, 196.

33. Ibid., 197.

34. When Camus does this his aim is always to reconcile the two. Nonetheless the distortion is real and responsible for some of the missteps of the analysis. The following passage is a good example of both aspects: "But when the church dissipated its Mediterranean heritage, it placed the emphasis on history to the detriment of nature, caused the Gothic to triumph over the romance, and, destroying a limit in itself, has made increasing claims to temporal power and historical dynamism. When nature ceases to be an object of contemplation and admiration, it can be nothing more than the material for an action that aims at transforming it. These tendencies - and not the concepts of mediation, which would have comprised the real strength of Christianity - are triumphing in modern times." Albert Camus, The Rebel, 299.

35. Albert Camus, The First Man, 196-197.

36. Albert Camus, "The Desert" in Lyrical and Critical Essays, 98.

37. Albert Camus, The First Man, 257.

38. Ibid. 
Ph.D. Thesis - R. Srigley McMaster - Religious Studies

39. Ibid., 262-263.

40. Ibid., 268. Camus offers a the same basic analysis of the emptiness of modern bourgeois capital in his essay "Create Dangerously": "For about a century we have been living in a society that is not even the society of money (gold can arouse carnal passions) but that of the abstract symbols of money. The society of merchants can be defined as a society in which things disappear in favour of signs. When the ruling class measures its fortunes, not by the acre of land or the ingot of gold, but by the number of figures corresponding ideally to a certain number of exchange operations, it thereby condemns itself to setting a certain kind of humbug at the center of its experience and its universe. A society founded on signs is, in its essence, an artificial society in which man's carnal truth is handled as something artificial." Albert Camus, Resistance, Rebellion, and Death, 253254.

41. Ibid., 267-268.

42. See Max Weber, The Protestant Ethic and the Spirit of Capitalism, trans. Talcott Parsons (New York: HaperCollins Academic, 1991).

43. Albert Camus, The First Man, 193.

44. Camus admires this type of restraint in Roger Martin du Gard's assessment of the vices of the bourgeois. See Albert Camus, "Roger Martin du Gard" in Lyrical and Critical Essays, 286-287. Camus' essay also serves as the Preface to the Gallimard edition of Roger Martin du Gard's collected works.

45. Albert Camus, The First Man, 268.

46. Ibid., 269.

47. Ibid.

48. Ibid.,

49. See Karl Marx, "Contribution to the Critique of Hegel's Philosophy of Right" in Karl Marx, Early Writings, trans. and ed. T. B. Bottomore (New York: McGraw-Hill Book Company, 1963), 43-59.

50. Albert Camus, The First Man, 238-240. 
Ph.D. Thesis - R. Srigley McMaster - Religious Studies

51. See Norman Cohn, The Pursuit of the Millennium: Revolutionary Millenarians and Mystical Anarchists of the Middle Ages (London: Pimlico, 2004), 21.

52. Albert Camus, The Rebel, 23-25, 32, 247.

53. This is one of the main arguments of chapter two of this work.

54. Oliver Todd, Albert Camus: A Life, 17-18.

55. Plato, The Republic, trans. Allan Bloom, (New York: Basic Books, 1968), 606a.

56. Ibid., 604c.

57. Albert Camus, The First Man, 239.

58. Ibid.

59. Ibid.

60. Ibid.

61. Ibid., 240.

62. Ibid., 184.

63. This is a constant theme in The First Man. It was also a theme in one of Camus' earliest essays, "The New Mediterranean Culture," published in 1937. Though Camus frequently formulates this influence of the Mediterranean negatively, here he intimates its positive content: "There are, before our eyes, realities stronger than we ourselves are. Our ideas will bend and become adapted to them." Albert Camus, "The New Mediterranean Culture" in Lyrical and Critical Essays, 195.

64. This is the argument of Letters to a German Friend, which Camus published serially in the Revue Libre and Cahiers de Libération in 1943 and 1944. See Albert Camus, Resistance, Rebellion, and Death, trans. Justin O'Brien (New York: Vintage Books, 1974), 3-32. It is also an argument he makes against both sides of the Algerian conflict, whose violent stances, whether ideological or cynical, he believed would tear the country apart and profit no one but foreign powers like the Soviet Union whose real interests where global and had nothing to do with the well-being of Algerian civil society. See Ibid., 111-153. 
Ph.D. Thesis - R. Srigley McMaster - Religious Studies

65. Albert Camus, The First Man, 240.

66. Ibid.

67. Ibid., 239.

68. Camus writes the following in his notes for the book: "I want to write the story of a pair joined by the same blood and every kind of difference. She similar to the best this world has, and he quietly abominable. He thrown into all the follies of our time; she passing through the same history as if it were that of any time. She silent most of the time, with only a few words at her disposal to express herself; he constantly talking and unable to find in thousands of words what she could say with a single one of her silences... Mother and son." Ibid., 310.

69. "He had tried to escape from anonymity, from a life that was poor, ignorant, and mulish; he could not live that life of blind patience, without words, with no thought beyond the present." Ibid., 196.

70. The full text reads as follows: "The misfortune in the nature of things, which the contemplative Aryan is not inclined to interpret away - the contradiction at the heart of the world reveals itself to him as a clash of different worlds, e.g., of a divine and human one, in which each, taken as an individual, has right on its side, but nevertheless has to suffer for its individuation, being merely a single one beside another." Friedrich Nietzsche, The Birth of Tragedy and The Case Against Wagner, trans. Walter Kaufmann (New York: Vintage Books, 1967), Section 9. Camus used Nietzsche's account in an early work entitled "Essay on Music." Albert Camus, Youthful Writings, trans. Ellen Conroy Kennedy (New York: Alfred A. Knopf, 1976), 130-155.70.

71. Martin Buber, $I$ and Thou, trans. Walter Kaufmann, (New York: Charles Scribner's Sons, 1970).

72. See Martin Buber, The Letters of Martin Buber: A Life of Dialogue, eds. Nahum N. Glatzer and Paul Mendes-Flohr, trans. Richard and Clara Winston and Hary Zohn (New York: Schocken Books, 1991), 568-569.

\section{Albert Camus, The First Man, 281-282.}

74. This boundlessness is suggested by the immensity of the landscapes that symbolize it as well as by its namelessness. See Ibid., 281, 196, 171. In Buber's language such realtions are without borders. "Whoever says You does not have something for his object. 
Ph.D. Thesis - R. Srigley McMaster - Religious Studies

For wherever there is something there is also another something; every It borders on other Its; It is only by virtue of bordering on others. But where You is said there is no something. You has no borders." Martin Buber, I and Thou, 55.

75. Albert Camus, Christian Metaphysics and Neoplatonism, 102 n49. Albert Camus, Lyrical and Critical Essays, 228-241. The work by Parain that Camus discusses is Essai sue le logos platonicien (Paris: Gallimard, 1941).

76. The three best examples of this use of Plato occur in three different texts, The Stranger, "The Enigma," and The Rebel. In each case Camus uses Plato's image of the cave from the Republic in order to explain some facet of the modern project and to suggest a way out of it. See Albert Camus, The Outsider, trans. Joseph Laredo (London: Penguin Books, 1983), 71-75. Albert Camus, Lyrical and Critical Essays, 161. Albert Camus, The Rebel, 286.

77. "The third stage is love: The First Man, Don Faust. The Myth of Nemesis." Albert Camus, Carnets III: Mars 1951-Décembre 1959, 187.

78. Albert Camus, Notebooks 1942-1951, 263, 267.

79. Albert Camus, Lyrical and Critical Essays, 7, 15.

80. Albert Camus, The First Man, 196.

81. See Ibid. for the first assessment. See Ibid. 278 for an example of the latter. "Preparing himself even by dint of poverty to be able one day to receive money without ever seeking it or submitting to it, to be as he was now - he, Jacques, at age forty, holding sway over so much and yet so certain that he was less than the least of people, and nothing in any case next to his mother."

82. See note 80 above.

83. As originally conceived, The First Man was to be a triptych, the third part of which would bear the title: "The Mother." Albert Camus, The First Man, 309.

84. Ibid., 3-19.

85. Henri Cormery fought in two wars, was the manager of a large property, had a wife and family, and accomplished all this after being raised in an orphanage. 
Ph.D. Thesis - R. Srigley McMaster - Religious Studies

86. "For it was just that that his father had in common with the men of the Labrador. The Mahon people of the Sahel, the Alsatians on the high plateaus, with this immense island between sand and sea, which the enormous silence was now beginning to envelop: the silence of anonymity; it enveloped blood and courage and work and instinct, it was at once cruel and compassionate." Ibid., 194, 185.

87.See the description of this group in chapter 7: "Mondovi: The Settlement and the Father." Ibid., 177-197.

88. Ibid., 191.

89. This is an argument that Camus had made in his analysis of the crisis in Algeria. It was demonized as simply the softer colonialism of the pied noir by the left and considered soft by the right for other reasons. For a detailed statement of the position, see Albert Camus, Resistance, Rebellion, and Death, 111-153.

90. The first instance is the birth of his son, Jacques. Ibid. The second occurs during his stint in the Zouave regiment during the Moroccan war. Ibid., 64-67. In neither case is Henri overwhelmed by the circumstances, though they are demanding. He is quiet, but he seems to know what to say and do when faced with difficult choices or experiences.

91. Jacques and the family is entitled to free medical care as a result of his death in combat.

92. According to the argument of The Rebel, there is no substantial difference between East and West in this regard because "the imperative of production dominates both universes and makes them, on the economic plane, one world." Albert Camus, The Rebel, 218.

93. Albert Camus, The First Man, 267-269. This too is an account that won Camus little more than scorn from the great defenders of the poor among twentieth century Parisian intellectuals. For Camus' explanation of his view, see Albert Camus, Lyrical and Critical Essays, 8.

94. Albert Camus, Lyrical and Critical Essays, 12.

95. Plato, Symposium, trans. Seth Benardete (London: Bantam Classics, 2006), $203 \mathrm{~b}$. Camus was familiar with the text. Parts of it are contained in a passage from Plotinus' Enneads in Christian Metaphysics and Neoplatonism. See Albert Camus, Christian Metaphysics and Neoplatonism, trans., Ronald Srigley (Columbia: University of Missouri 
Ph.D. Thesis - R. Srigley McMaster - Religious Studies

Press, 2007), 102.

96. Plato, Symposium, 177de.

97. Albert Camus, Lyrical and Critical Essays, 15. The importance of love is attested in many places in Camus corpus. The following passage from Camus notebooks is indicative of the nature of this attestation. "Not morality but fulfillment. And there is not other fulfillment than that of love, in other words of yielding to oneself and dying to the world. Go all the way. Disappear. Dissolve in love. Then the force of love will create without me. Be swallowed up. Break up. Vanish in fulfillment and the passion of truth." Albert Camus, Notebooks 1942-1951, 243.

98. Augustine, Confessions, trans. R.S. Pine-Coffin (London: Penguin Books, 1961), book VII, 17-21.

99. Augustine, The City of God, Book XIV, trans. G. Walsh, D. Zema, G. Monahan, D. Honan (New York: Image Books, 1958).

100. The erotic ascent that Socrates/Diotima describes, which is neither theoretical nor metaphysical but moral and aesthetic, must incorporate into itself and account for the whole order of being in order to be completed properly. See Plato, Symposium, 210a212a.

101. Albert Camus, The First Man, 169-176.

102. Ibid., 169.

103. Plato, Symposium, 194a-d. Agathon's willingness to pander to popular opinion for the glory and riches it brings is illuminated through Socrates' questioning of him before he speaks.

104. Ibid, 201c.

105. Albert Camus, The First Man, 170.

106. Plato, Symposium, 175e.

107. Albert Camus, The First Man, 170.

108. This might also be Camus' reformulation of the Eucharist. We are all Christ, we are all children of God, and thus we all partake of that reality by nature. 
Ph.D. Thesis - R. Srigley McMaster - Religious Studies

109. Plato, Symposium, 198c.

110. Ibid., 194a.

111. Ibid., 201e.

112. Ibid., 201c-203a.

113. Ibid., $202 b$.

114. Ibid., 209e-210a.

115. This is a theme that runs throughout The Rebel. The following passage is typical. Though it mentions metaphysical rebellion and not Christianity as the source of the distinction, Christianity is implicated in the claim because it is the original source from which metaphysical derives its meaning. "Metaphysical rebellion presupposes a simplified view of creation - which was inconceivable to the Greeks. In their minds there were not gods on one side and men on the other, but a series of stages leading from one to the other. The idea of innocence opposed to guilt, the concept of all history summed up in the struggle between good and evil, was foreign to them." Albert Camus, The Rebel, 28.

116. Albert Camus, The First Man, 170-171.

117. Ibid., 171.

118. Ibid.

119. Ibid., 172.

120. Ibid.

121. Plato, Symposium, 203b.

122. Eleanor Wachtel wonders about the oddness of Camus relationship to his mother and to women generally during an interview with Oliver Todd. Eleanor Wachtel, "Albert Camus: Prophet of Our Age," Queen's Quarterly, Fall 1999, Vol. 106, 367-381.

123. This is in part the argument of The Plague. It is particularly apparent in the increasingly grotesque treatment of those infected with the disease and the downward spiral in the handling of the dead. 
Ph.D. Thesis - R. Srigley McMaster - Religious Studies

124. Albert Camus, The Plague, trans. Stuart Gilbert (London: Penguin Books, 1960), 213.

125. Plato, Symposium, 210a.

126. Albert Camus, The First Man, 172.

127. Plato, Symposium, 209a.

128. Ibid.

129. Albert Camus, The First Man, 177.

130. Ibid., 185.

131. Ibid., 190.

132. Ibid., 181.

133. Albert Camus, Resistance, Rebellion, and Death, 116.

134. Ibid.

135. Albert Camus, The First Man, 181.

136. Ibid.

137. "Yet whoever hates directly is closer to a relationship than those who are without love or hate." Martin Buber, I and Thou, 68.

138. No one in the extant part of The First Man identifies Moscow as a player in the Algerian war. But Camus does do so in his "Algerian Reports." Albert Camus, Resistance, Rebellion, and Death, 146.

139. See George Orwell, Nineteen Eighty-Four (London: Penguin Books, 1990) for an account of this condition.

140. The full text reads as follows: "In the Middle Ages the hostile forces were held together by the church and, through the strong pressure it exerted, to some extent assimilated with one another. When the bond broke, the pressure relaxed, they rebelled against one another. The Reformation declared many things to be adiaphora, domains 
Ph.D. Thesis - R. Srigley McMaster - Religious Studies

where religion did not hold sway; this was the price at which it purchased its existence: just as Christianity had already had to pay a similar price in face of the much more religiously inclined world of antiquity." Friedrich Nietzsche, "Schopenhauer as Educator" in Untimely Meditations, trans. R.J. Hollingdale (Cambridge: Cambridge University Press, 1983), 150.

141. Albert Camus, The First Man, 171.

142. Albert Camus, The Rebel, 190.

143. In this respect the language of The First Man is breathless and in some ways less circumspect than what we find in books like The Wrong Side and the Right and Nuptials. But we have to keep in mind the unfinished and highly provisional nature of the manuscript.

144. Plato, Symposium, 202e.

145. Albert Camus, Lyrical and Critical Essays, 7.

146. Albert Camus, The First Man, 278.

147. Ibid., 281, 279.

148. Albert Camus, "The Winds of Djemila" in Lyrical and Critical Essays, 76.

149. Albert Camus, "The Desert." See particularly his account of life after completing his ascent to the top of the Boboli gardens form which he can see Mount Oliveto. Ibid., 102105.

150. Albert Camus, The Rebel, 2.

151. See Ibid., 24, 247, 303.

152. Albert Camus, The First Man, 26.

153. Ibid., 284.

154. Ibid., 194, 196.

155. Ibid., 284. 
Ph.D. Thesis - R. Srigley McMaster - Religious Studies

156. Ibid.

157. Ibid., 303. 
Ph.D. Thesis - R. Srigley McMaster - Religious Studies

\section{CONCLUSION}

A good way to continue Camus' project is to examine an aspect of his corpus that commentators discuss but rarely examine in detail because they assume that its meaning is self-evident. I am speaking of the structure of Camus' oeuvre as a whole, including the structure of the cyclical books that I have discussed in this thesis. This structure is intentional, though it did not come all at once and though certain elements of it may not have been entirely clear even to Camus, particularly at the time he was writing them. These qualifications notwithstanding the structure is there and requires interpretation. The following pages are an attempt to explain what I have learned about this structure and to offer suggestions about what still needs to be done to understand it more fully.

Figure 1 below gives the reader a brief overview of the chronology and structure of Camus' principal works. Most commentators interpret the cyclical works autobiographically and chronologically. They argue that these books contain Camus' own best understanding of the subjects he discusses and that they reveal a kind of straightforward improvement or development in his thinking. The Myth of Sisyphus is better than The Wrong Side and the Right Side and Nuptials; The Rebel is better than all three; and the books that were to comprise the third cycle works on love would have surpassed them all. Though there are aspects of the chronological interpretation that are certainly correct, its two principal claims are false and misleading. ${ }^{1}$ Each subsequent book that Camus wrote may have been better than the one that preceded it in the sense that it 
Ph.D. Thesis - R. Srigley McMaster - Religious Studies reflects a greater level of maturity and because it more adequately illuminates the aspect of modernity that was his primary concern. In that limited sense Camus' books certainly expressed what he 'thought' about their subjects. But that is all we can say about the matter. In "The Enigma" Camus tells us explicitly that in crafting his books one of his Figure 1: Chronology and Structure of Camus' Principal Works

\begin{tabular}{|c|c|c|}
\hline Historical/Thematic Sta & Major Works & $\begin{array}{l}\text { Lyrical } \\
\text { Essays }\end{array}$ \\
\hline $\begin{array}{l}\text { Early Works } \\
\text { (Mid to Late 1930s) }\end{array}$ & $\begin{array}{l}\text { Christian Metaphysics } \\
\text { The Wrong Side and the Right } \\
\text { Side } \\
\text { Nutpials }\end{array}$ & $\begin{array}{l}\text { "The New Mediterranean } \\
\text { Culture" } \\
\text { "Melusina's Children" } \\
\text { "Voices from the poor } \\
\text { Quarter" }\end{array}$ \\
\hline $\begin{array}{l}\text { The Absurd } \\
\text { (Early 1940s) }\end{array}$ & $\begin{array}{l}\text { Novel: The Stranger } \\
\text { Essay: The Myth of Sisyphus } \\
\text { Plays: The Misunderstanding } \\
\quad \text { Caligula }\end{array}$ & $\begin{array}{l}\text { "The Minotaur" } \\
\text { "The Almond Trees" } \\
\text { Letters to a German } \\
\text { Friend }\end{array}$ \\
\hline $\begin{array}{l}\text { Rebellion } \\
\text { (Late 1940s - Early 1950s) }\end{array}$ & $\begin{array}{l}\text { Novel: The Plague } \\
\text { Essay: The Rebel } \\
\text { Plays: State of Siege } \\
\text { The just Assassins }\end{array}$ & $\begin{array}{l}\text { "Prometheus in the } \\
\text { Underworld" } \\
\text { "Helen's Exile" } \\
\text { "The Enigma" } \\
\text { "Return to Tipasa" }\end{array}$ \\
\hline${ }^{2}$ & We twi & $\begin{array}{l}\text { SOn the future of } \\
\text { Tragedy }\end{array}$ \\
\hline
\end{tabular}


Ph.D. Thesis - R. Srigley McMaster - Religious Studies

\begin{tabular}{|l|l|l|}
\hline $\begin{array}{l}\text { Love } \\
\text { (Late 1950s) }\end{array}$ & $\begin{array}{l}\text { Novel: The First Man } \\
\text { Essay: "The Myth of Nemesis" } \\
\text { Play: "Don Faust" }\end{array}$ & $\begin{array}{l}\text { "Create Dangerously" } \\
\text { "On Jean Grenier's Les } \\
\text { Iles" }\end{array}$ \\
\hline
\end{tabular}

primary goals was to be an "objective writer," that is to say, "one who chooses themes without ever taking himself as the subject." ${ }^{22}$ And contrary to the notion of improvement inherent in the chronological interpretation, Camus admitted publically that often when he thought he was "moving forward" he was actually "losing ground."

If Camus' books are not straightforward autobiography then their themes were chosen for other reasons. Those reasons require interpretation. And so too do the ups and downs and reversals and repetitions apparent in the books themselves. In addition to the occasional failure that Camus himself acknowledges, there are other instances in which he intentionally withholds his best insights in a book in order to linger over a certain modern problem or to lay the groundwork for an account he will develop in a subsequent work. The provisional character of The Myth of Sisyphus and The Rebel are good examples of this type of withholding. The Myth of Sisyphus is at most a "point of departure"; and Camus warns the reader that the analysis of modernity in The Rebel will not "go to the root of things." This method may not be amenable to a certain democratic sensibility or compatible with the bourgeois notion of honesty. Nonetheless Camus thought it was an essential feature of all good pedagogy or persuasion and made it a 
Ph.D. Thesis - R. Srigley McMaster - Religious Studies central feature of the organization and content of his books. ${ }^{5}$

There is a far greater complexity and much more substance to the cyclical structure of Camus' books than what is supposed by the chronological interpretation. Even the latter's most basic claims are not borne out by the facts. Rebellion may be an essential feature of life and therefore require some explanation. But there is no indication in Camus' books that it is superior to the absurd once the meaning of that experience has been critically clarified. Rebellion is a facet of existence - sometimes called for, sometimes not - but like any other experience, always capable of distortion and excess. So too with the absurd. These things stand along side one another as different dispositions or moods in existence and not as experiences that are related to one another causally or logically. Camus does occasionally speak in this way, it is true, but it is not what his analyses themselves teach us. ${ }^{6}$

Contrary to the chronological interpretation, if there is a meaning to the sequence of the cycles what it reveals is not some kind of progress or improvement but a downward movement in which the descriptions generated by the analyses depict an increasingly violent and disordered world. The divorce from reality of the absurd is certainly a lamentable condition to find oneself in, but it is pretty small beer in comparison to the willful refusal and distortion of reality pursued as a matter of principal by metaphysical and historical rebellion. And as bad as both these things are, they do not compare to the totalitarian ambitions and "sweet dreams of oppression" that are Clamence's explicit 
Ph.D. Thesis - R. Srigley McMaster - Religious Studies ambition in The Fall. ${ }^{7}$ In other words, the sequence of the cyclical books charts a movement in which the historical and philosophical phenomena they describe either become progressively worse or are examined in such a way that their constant and ultimately violent character becomes increasingly clear. It may be that both interpretations are true.

This downward movement of the cyclical books is attested to and further illuminated by the iconography that Camus employs to describe it. Two images stand out for our consideration. The first is the familiar pair of terms "exile" and "homeland" or "patrie" that Camus uses extensively in his books. ${ }^{8}$ The second is the image of a descent from an existentially satisfactory place or condition to one that is far less satisfactory. The two most common images that Camus uses to depict this descent are both Greek, though there might also be a suggestion of a Christian source in the texts. ${ }^{9}$ The first is the Greek notion of Hades that Camus derives from a number of different sources. ${ }^{10}$ The second image is also Greek but the source from which it is taken is quite specific. It is the image of the cave from book VII of Plato's Republic. ${ }^{11}$ The exile/homeland image and the image of descent, whether the latter is taken to refer to Plato's cave or to the Greek hades more generally, are roughly equivalent symbolisms. Together they help to explain the nature and aim of Camus' cyclical books. The cyclical books are Camus' attempt to understand and explain the nature of modernity. Each cycle of books begins with an experience that Camus finds "in the streets of his time." ${ }^{\text {"12 }}$ But these experiences and the analyses they 
Ph.D. Thesis - R. Srigley McMaster - Religious Studies

provoke are not all equally successful in leading Camus to the heart of the modern project. Each new stage of the analysis pushes the descent a little further, sheds greater light on the nature of our exile, and is more intrepid and less compromising in doing so than the one the preceded it. The process as a whole, at least in terms of the extant texts, reaches its conclusion in The Fall, in which Camus offers his best interpretation and assessment of modernity. In terms of the iconography of both the cyclical books and the text itself, The Fall is the last circle of hell, the furthest point of the descent and the darkest part of the cave that is modernity.

The nature and aim of this descent accounts for many of the confusions we have encountered in Camus' analyses. The existential darkness of modernity is real, like the darkness of Plato's cave; and descending into it was as disorienting for Camus as it was for Socrates' prisoner. ${ }^{13}$ But since the descent was also undertaken willingly, it is clear that Camus was aware that its existential darkness was not exhaustive of reality. Moreover he also seems to have made provisions for the journey by taking steps to ensure that he not be lost in the darkness completely once the descent had begun. This is not speculation. Both aspects of the iconography have their textual correlates in Camus' corpus. Though they address the same questions as the cyclical books, these texts stand outside the cyclical structure. Moreover they answer these questions in a different voice and a broader context. It is to these texts that I now turn.

The books with which Camus began his career are The Wrong Side and the Right 
Ph.D. Thesis - R. Srigley McMaster - Religious Studies

Side and Nuptials. They antedate the cyclical structure entirely. What is notable about them is that although they explore almost all of the experiences that Camus will examine later in the cyclical books - the absurd, rebellion, love ${ }^{14}$ - they do so without the distorting influence of the distinctively modern interpretations that will hamper those subsequent analyses. ${ }^{15}$ These books constitute Camus' most complete non-modern or premodern account of the world and of human life. Together they constitute the place from which he begins his descent into modernity; and according to the argument of the 1958 Preface to The Wrong Side and the Right Side and of the cyclical structure itself, it was also the place to which he aimed to return in the third cycle of books on love. The project as a whole therefore entails a journey of descent and ascent over the course of which Camus hoped to clarify the nature of modernity and to articulate an account of the world beyond or apart from its influence. And as we have seen this journey is also related to his attempt to restore the Greeks. The transition from the Greeks to Christianity was the subject of Camus' first book-length essay, Christian Metaphysics and Neoplatonism, ${ }^{16}$ which was written about the same time as The Wrong Side and the Right Side and Nuptials. That transition was the historical source of modernity and would become one of the principal objects of Camus' critical analysis in the cyclical books. Understanding the nature of that transition was therefore essential to the task of these books. Camus does some of the preliminary work for that analysis in several cyclical works - The Myth of Sisyphus, The Plague, State of Siege, and The Rebel. But sometime in the late 1940s or 
Ph.D. Thesis - R. Srigley McMaster - Religious Studies early 1950 s he decided that a full examination of the matter had to be undertaken and that it would form the content of his proposed third philosophical essay, "The Myth of Nemesis." ${ }^{\text {17 }}$ So the Greeks are found at both the beginning and the end of Camus' project. They are the pre-Christian and pre-modern place from which his examination begins and to which it would return once the analysis of Christianity and modernity had been completed.

There is one final group of works in Camus' corpus that still needs to be accounted for - the lyrical and political essays that accompany the cyclical books chronologically. If a comparison needs to be made, then I would say that the works that they most closely approximate in both style or content are The Wrong Side and the Right Side and Nuptials. Like those early books the unusual thing about these essays is the fact that although they address the same themes as the cyclical books with which they are contemporary, they do not suffer from the latter's modern confusions. Indeed this fact is even more unusual and perplexing in this case because these essays are contemporaneous with the cyclical books whose analyses they improve or surpass. For instance "Helen's Exile," which was published in 1948 , explores the problem of rebellion but it does so in a way that is far clearer and far less prone to the excesses of metaphysical rebellion than is the analysis that Camus will offer some four years later in The Rebel. Even his brief assessments of figures like Dostoevsky and Hegel and his identification of the desire for immortality as the source of modern metaphysical rebellion are much more circumspect 
Ph.D. Thesis - R. Srigley McMaster - Religious Studies and compelling in this work than they are in the later analysis. ${ }^{18}$ It would take a good deal of textual argument to substantiate this claim adequately. There is no time here to make that argument, though I believe it is both possible and necessary to do so. Nonetheless I think there is sufficient prima facie evidence to support the claim. ${ }^{19}$ How are we to explain this odd structure?

I would say that these shorter lyrical essays serve as periodic reminders both to Camus and to his readers of a reality that exceeds or transcends the one in which they find themselves and to which he and they should ultimately aspire to return. In a more formal sense it could be argued that these essays serve the same function as does the Chorus in a Greek tragedy, at least as Camus himself understood that function. In his essay "The Future of Tragedy" Camus argues that the role of the Chorus in the best Greek tragedies is to warn against excess and to encourage the various protagonists to recognize and accept the limitations on their ambitions and desires imposed by the order of existence. ${ }^{20}$ So too Camus' lyrical and political essays. They too warn against excess - the modern excesses that Camus explores in his cyclical books. And they do so by pointing to a kind of cosmic order that moderns overlook or refuse to countenance and that Camus himself was sometimes in danger of missing in the very act of developing his critical analyses of these phenomena. In another sense they might simply be examples of Nietzsche's council that when fighting ugly truths it is essential to run out into the sunlight as frequently as possible in order to retain one's cheerfulness and good sense. While carrying out his 
Ph.D. Thesis - R. Srigley McMaster - Religious Studies critical analysis Camus regularly paused to reflect on his subject matter in a way that was more in keeping with his earlier books and much freer and more forthright than what we find in the cyclical books. Much of that reflection is contained in these lyrical and political essays. I think we could learn a great deal from them that could help to correct or mitigate the occasional excesses of the cyclical books and give us a better sense of how Camus understood the Greeks.

Figure 2 below illustrates pictorially the substantive relationships between the last cycle of books, the early works, and these lyrical essays. The highlighted works share a similar clarity and insight that distinguishes them from the cyclical books. Taken as a whole the structure indicates the movement of descent I have described above; Camus' continual warnings to himself not to be lost in modernity's confusions while exploring its nature; and finally his desire to return from this exile or sojourn through the modern world to an existentially more satisfying place, to "learn one last time what [he knows]."21 Figure 2: Substantial Relationships Among Camus' Principal Works

$\begin{array}{lll}\text { Historical/Thematic Stages } & \text { Major Works } & \begin{array}{l}\text { Lyrical } \\ \text { Essays }\end{array}\end{array}$

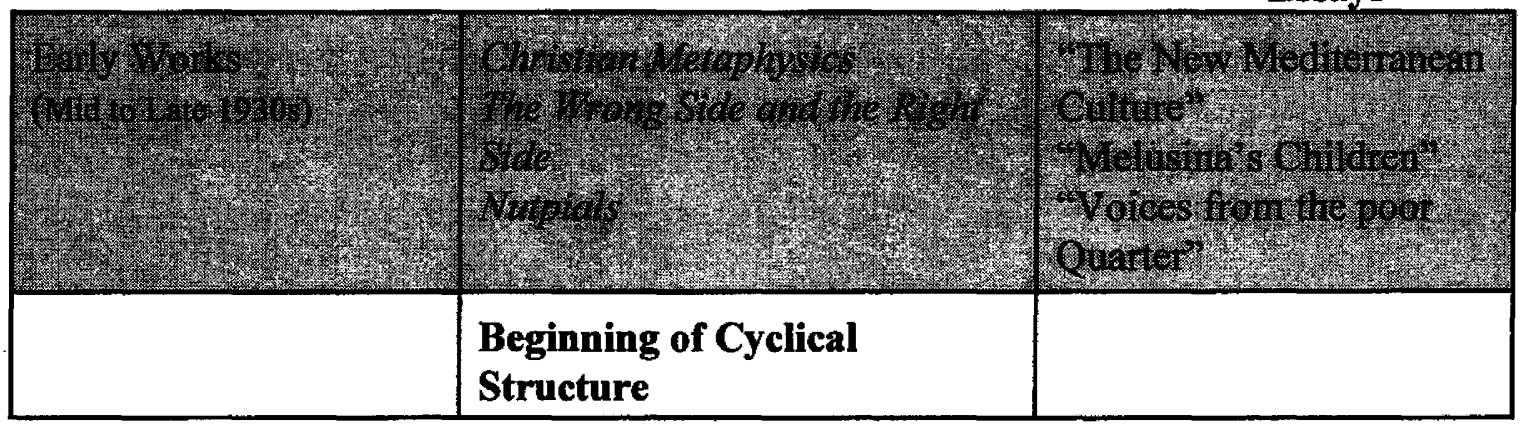


Ph.D. Thesis - R. Srigley McMaster - Religious Studies

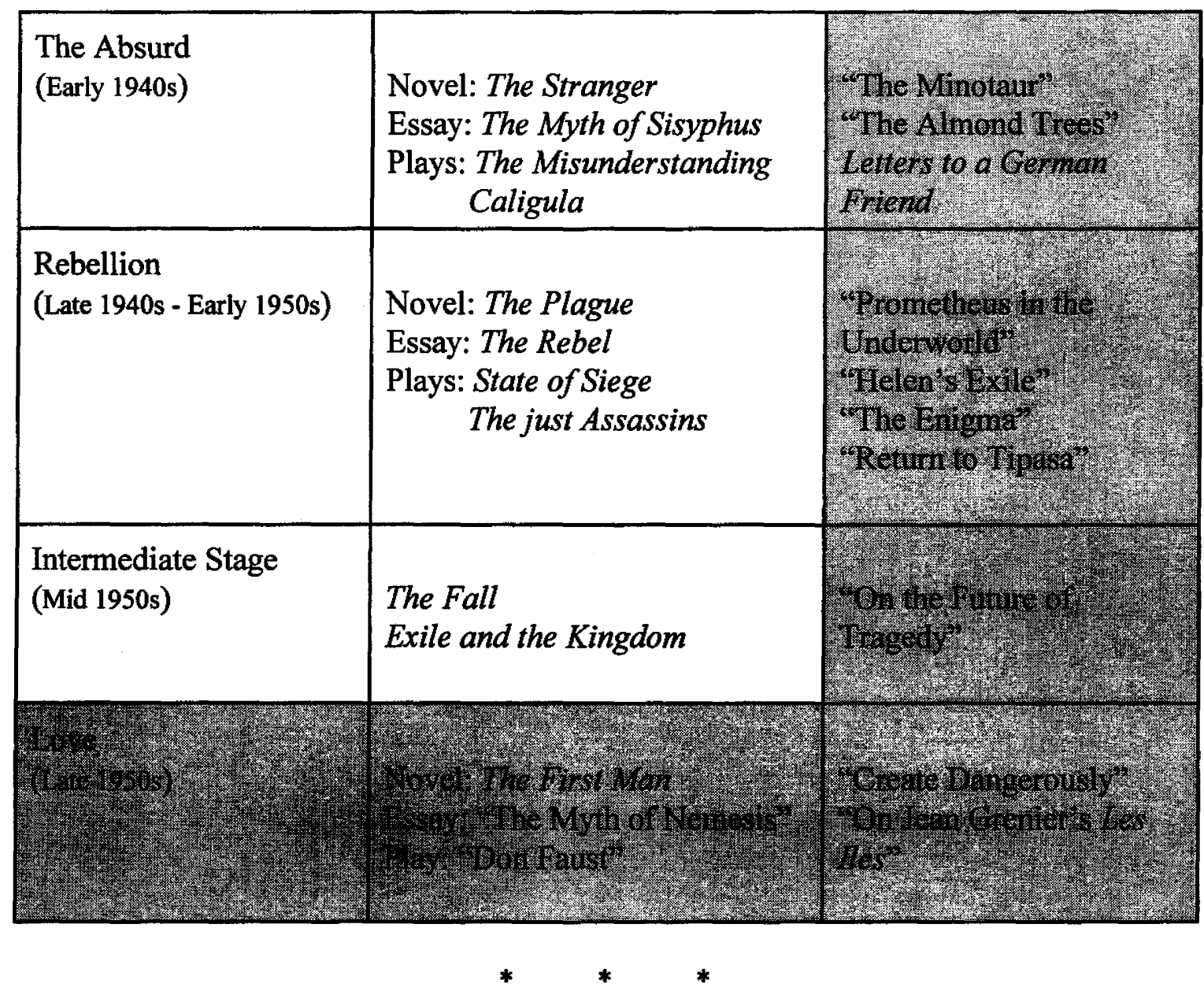

These are the structures in Camus' oeuvre that still need to be explored to complete the analysis I have begun in this thesis. I think a detailed examination of them would repay the effort and shed even more light on the content of Camus books. It might also assist us in our attempt to continue Camus' project to restore the Greeks and to explain more fully what they have to teach us. The brief analysis I have just offered hopefully gives us an idea of some of the exegetical work that still remains to be done. 
Ph.D. Thesis - R. Srigley McMaster - Religious Studies

Notes

1. See note 83 from the Introduction for a list of my sources for this style of interpretation.

2. Albert Camus, "The Enigma" in Lyrical and Critical Essays, 159.

3. Albert Camus, Lyrical and Critical Essays, 14.

4. Albert Camus, The Myth of Sisyphus, 10; Albert Camus, The Rebel, 4.

5. One should note in this respect Camus' admiration for the pedagogical method of Father Pouget as he describes it is his review of M. Guitton's book, Le Portrait de M. Pouget. Ibid., 219-227.

6. In The Rebel, for instance. "Absurdism, like methodical doubt, has wiped the slate clean. It leaves us in a blind alley. But, like methodical doubt, it can, by returning upon itself, open up a new field of investigation, and the process of reasoning then pursues the same course. I proclaim that I believe in nothing and that everything is absurd, but I cannot doubt the validity of my proclamation and I must at least believe in my protest. The first and only evidence that is supplied me, within the terms of the absurdist experience, is rebellion." Albert Camus, The Rebel, 10.

\section{Albert Camus, The Fall, 55}

8. They are central images in The Plague; and not surprisingly they also figure prominently in the book that bears a variant of them in its title, Exile and the Kingdom. In addition to these works they are a constant feature in Camus' shorter, lyrical essays.

9. In "Prometheus in the Underworld" the term that Camus uses is "enfer." This can be translated in English either as "hell" or "hades." A Christian translation of the term does not seem to mitigate Camus' preference for the Greeks. Since the term is intended to denote modernity's excesses, those excesses would appear as Christian derivations and not properly Greek at all. Either translation seems to work well enough. Albert Camus, "Prométhée aux enfers" in Essais (Paris: Gallimard, 1965), 842.

10. Homer's Odyssey is Camus' most obvious source. See Albert Camus, Notebooks 1942-1951, 13. But Camus also seems to have used Eschylus' Prometheus Bound. See Albert Camus, "Prometheus in the Underworld" in Lyrical and Critical Essays, 139. 
Ph.D. Thesis - R. Srigley McMaster - Religious Studies

11. Plato, Republic, 514a-520d. Camus uses the image in "The Enigma" and in The Rebel. Albert Camus, "The Enigma" in Lyrical and Critical Essays, 161. Albert Camus, The Rebel, 286.

12. Albert Camus, "The Enigma" in Lyrical and Critical Essays, 159.

13. Plato, Republic, 516e-517a.

14. Here is a list of some of the most explicit references: the absurd: The Wrong Side and the Right Side 36, 39, 46, 56, 61; Nuptials 75-6, 78, 81, 92; rebellion: The Wrong Side and the Right Side 47; Nuptials 75, 76, 99; love: The Wrong Side and the Right Side 56, 60; Nuptials 68-9, 102, 105.

15. For a detailed analysis of how this works in the case of one of the essays included in Nuptials - "The Desert" - see my unpublished manuscript "Camus' Erotic Ascent."

16. Camus completed Christian Metaphysics and Neoplatonism in May of 1936. The Wrong Side and the Right Side was published in 1937; Nuptials was published in 1938.

17. Albert Camus, Notebooks 1942-1951, 257. Albert Camus, Carnets III: Mars 1951Décembre 1959, 187.

18. Albert Camus, "Helen's Exile" in Lyrical and Critical Essays, 150, 152.

19. That evidence is threefold: Camus' own testimony in the 1958 Preface to The Wrong Side and the Right Side; the kinds of comparative analyses I have made; and the testimony of some of Camus' best readers regarding the superiority of the lyrical works. Regarding the latter, see Thomas Merton, "Camus: Journals of the Plague Years," The Sewanee Review, Autumn, 1967 and Serge Doubrovsky, "The Ethics of Albert Camus" in Camus: A Collection of Critical Essays, ed. Germaine Brée (Englewood Cliffs: PrenticeHall, Inc, 1962), 71-84.

20. Albert Camus, "The Future of Tragedy" in Lyrical and Critical Essays, 305. Camus is certainly partial right about the function of the Chorus, but not entirely. In a play like Antigone that Chorus' actions are at times far more questionable than Camus suggests.

21. Albert Camus, "Return to Tipasa" in Lyrical and Critical Essays, 171. 
Ph.D. - R. Srigley McMaster - Religious Studies

\section{BIBLIOGRAPHY}

Selected Works By Albert Camus:

A Happy Death. Trans. Richard Howard. New York: Vintage Books, 1973.

American Journals. Trans. Hugh Levick. New York: Paragon House Publishers, 1987.

Carnets III: Mars 1951-Décembre 1959. Paris: Gallimard, 1989.

Christian Metaphysics and Neoplatonism. Trans. Ron Srigley. Columbia: The University of Missouri Press, 2007.

Essais. Paris: Éditions Gallimard, 1965.

Exile and the Kingdom. Trans. Justin O'Brien, New York: Vintage International, 1991.

The Fall. Trans. Justin O'Brien. New York: Vintage International, 1991.

The First Man. Trans. David Hapgood. New York: Alfred A. Knopf Canada, 1995.

Lyrical and Critical Essays. Trans. Ellen Conroy Kennedy and ed. Philip Thody. New York: Vintage Books, 1970.

Neither Victims Nor Executioners. Trans. Dwight Macdonald. Philadelphia: New Society Publishers, 1986.

Notebooks 1935-1942. Trans. Philip Thody. New York: Paragon House, 1991.

Notebooks 1942-1951. Trans. Justin O’Brien. New York: Paragon House, 1991.

The Outsider. Trans. Joseph Laredo. London: Penguin Books, 1983.

The Plague. Trans. Stuart Gilbert. London: Penguin Books, 1960.

The Possessed: A Play in Three Parts. Trans. Justin O'Brien. New York: Vintage Books, 1964. 
Ph.D. - R. Srigley McMaster - Religious Studies

The Rebel. Trans. Anthony Bower. New York: Vintage Books, 1991.

Resistance, Rebellion, and Death. Trans. Justin O'Brien. New York: Vintage Books, 1974.

Théâtre, récits, nouvelles. Paris: Gallimard, 1962.

Youthful Writings. Trans. Ellen Conroy Kennedy. New York: Alfred A. Knopf, 1976.

Other Works Cited:

Archambault, Paul. Camus' Hellenic Sources. Chapel Hill: The University of North Carolina Press, 1972.

Aristotle. Politics. Trans. Ernest Barker. Oxford: Oxford University Press, 1995.

Aristotle. Problems. Vol. 1, The Loeb Classical Library. Trans. W. S. Hett and ed. T. E. Page. Cambridge: Harvard University Press, 1936.

Aristotle, Nicomachean Ethics, Book II,

Aronson, Ronald. Camus and Sartre: The Story of a Friendship and the Quarrel that Ended It. Chicago: The University of Chicago Press, 2004.

Augustine. The City of God. Trans. G. Walsh, D. Zema, G. Monahan, D. Honan. New York: Image Books, 1958.

Augustine. Confessions. Trans. R.S. Pine-Coffin. London: Penguin Books, 1961.

Augustine. Homilies on the Gospel of John. In The Nicene and Post-Nicene Fathers, Vol. VII. Trans. J. Innes and ed. P. Schaff. Grand Rapids: Wm. B. Eerdmans Publishing Company, 1956.

Bataille, Georges. "The Age of Revolt." In The Absence of Myth. Trans. Michael Richardson. London: Verso, 1994.

Baudrillard, Jean. The Perfect Crime. Trans. Chris Turner. London: Verso, 1996. 
Ph.D. - R. Srigley McMaster - Religious Studies . The Spirit of Terrorism. Trans. Chris Turner. London: Verso, 2003.

.The Transparency of Evil: Essays on Extreme Phenomena. Trans. James Benedict. London: Verso, 1993.

Boldt-Irons, Leslie Anne. "The Fall from and Into Grace: Camus and Bataille on Happiness and Guilt." Nottingham French Studies, 36:2, Autumn 1997, 45-56.

Brée, Germaine. Camus: A Collection of Critical Essays. Ed. Germaine Brée. Englewood Cliffs: Prentice Hall, 1962.

. Camus and Sartre: Crisis and Commitment. NewYork: Delta Books, 1972.

Buber, Martin. The Letters of Martin Buber: A Life of Dialogue. Trans. Richard and Clara Winston and Hary Zohn and eds. Nahum N. Glatzer and Paul Mendes-Flohr. New York: Schocken Books, 1991.

. On the Bible: Eighteen Studies. Ed. Nahum Glatzer. New York: Schocken Books, 1982.

.I and Thou. Trans. Walter Kaufmann. New York: Charles Scribner's Sons, 1970.

Burnaby, John. Amor Dei: A Study of the Religion of St. Augustine. Norwich: The Canterbury Press, 1991.

Cohn, Norman. Cosmos, Chaos, and the World to Come: The Ancient Roots of Apocalyptic Faith. New Haven: Yale University Press, 1995.

. The Pursuit of the Millennium: Revolutionary Millenarians and the Mystical Anarchists of the Middle Ages. London: Pimlico, 2004.

Cooper, Barry. Action into Nature: An Essay on the Meaning of Technology. Notre Dame: University of Notre Dame Press, 1991.

Courtois, Stéphane. The Black Book of Communism. Trans. Jonathan Murphy and Mark Kramer. Cambridge: Harvard University Press, 1999.

Cruickshank, John. Albert Camus and the Literature of Revolt. London: Oxford 
Ph.D. - R. Srigley McMaster - Religious Studies

University Press, 1959.

Devaux, André-A. "Albert Camus : Le christianisme et l'hellénisme." Nouvelle Revue Luxembourgeoise, janvier-avril 1970, 11-30.

Dostoevsky, Fyodor. The Brothers Karamazov. Trans. Constance Garnett. New York: W. W. Norton \& Company, 1976.

Ellison, David R. Of Words and the World: Referential Anxiety in Contemporary French Fiction. Princeton: Princeton University Press, 1993.

1990. . Understanding Albert Camus. Columbia: University of South Carolina Press,

Favre, Frantz. Montherlant et Camus: une lignée nietzschéene. Paris: Lettres modernes minard, 2000.

Ferguson, Niall. The War of the World: Twentieth Century Conflict and the Descent of the West. London: Penguin Books, 2006.

Feyerabend, Paul. Conquest of Abundance: A Tale of Abstraction Versus the Richness of Being. Ed. Bert Terpstra. Chicago: The University of Chicago Press, 1999.

Fukuyama, Francis. The End of History and the Last Man. New York: Perennial, 1992.

Grenier, Jean. Albert Camus, Souvenirs. Paris: Gallimard, 1968.

Griffin, Susan. Pornography and Silence: Culture's Revenge Against Nature. (New York: Harper \& Row, 1981).

Hamilton, William. "The Christian, the Saint, and the Rebel: Albert Camus." In Forms of Extremity in the Modern Novel. Ed. Nathon A. Scott Jr. Richmond: John Knox Press, 1965.

Isaac, Jeffrey C. Arendt, Camus, and Rebellion. New Haven: Yale University Press, 1992.

Jeanson, Francis. “Albert Camus ou l'âme révoltée.” Les temps modernes. No. 79 Mai $1952,2070-2090$. 
Ph.D. - R. Srigley McMaster - Religious Studies

Judt, Tony. The Burden of Responsibility: Blum, Camus, Aron, and the French Twentieth Century. Chicago: The University of Chicago Press, 1998.

Kierkegaard, Søren Concluding Unscientific Postscript. Trans. David Swenson \& Walter Lowrie. Princeton: Princeton University Press, 1941.

.The Sickness Unto Death. Trans. Howard V. Hong \& Edna H. Hong. Princeton: Princeton University Press, 1980.

Koestler, Arthur. The Yogi and the Commissar and Other Essays. New York: The MacMillan Company, 1967.

Lewis, R. W. B. The Picaresque Saint. London: Gollancz Ltd., 1960.

Machiavelli, Niccolò. The Prince. Trans. Harvey C. Mansfield. Chicago: The University of Chicago Press, 1998.

Mansfield, Harvey C. Machiavelli's Virtue. Chicago: The University of Chicago Press, 1996. . Manliness. New Haven: Yale University Press, 2006.

Marx, Karl. "Contribution to the Critique of Hegel's Philosophy of Right" in Karl Marx, Early Writings. Trans. and ed. T. B. Bottomore. New York: McGraw-Hill Book Company, 1963, 43-59.

McLelland, Joseph C. Prometheus Rebound: The Irony of Atheism. Waterloo: Wilfred Laurier University Press, 1988.

McMahon, Robert. Augustine 's Prayerful Ascent: A Essay on the Literary Form of the Confessions. Athens: University of Georgia Press, 1989.

Melville, Herman. Herman Melville: Pierre, Israel Potter, The Piazza Tales, The Confidence-Man, Tales, Billy Budd. Ed. Harrison Hayford. New York: The Library of America, 1984.

Merton, Thomas. "Camus: Journals of the Plague Years." The Sewanee Review. Autumn, 1967. 
Ph.D. - R. Srigley McMaster - Religious Studies . The Plague: Introduction and Commentary. New York: The Seabury Press, 1968.

Modler, Karl W. Soleil et mesure dans l'cuvre d'Albert Camus, Paris: L'Hamattan, 2000.

Murchland, Bernard. "The Dark Night Before the Coming of Grace" in Camus: A Collection of Critical Essays. Englewood Cliffs: Prentice Hall, 1962, 67-68.

Murdoch, Iris. The Sovereignty of the Good, (London: Routledge \& Kegan Paul, 1970)

Nietzsche, Friedrich. Beyond Good and Evil: A Prelude to a Philosophy of the Future. Trans. Walter Kaufmann. New York: Vintage Books, 1966.

. The Birth of Tragedy and The Case Against Wagner. Trans. Walter Kaufmann. New York: Vintage Books, 1967. . On the Genealogy of Morals. Trans. Walter Kaufmann. New York: Vintage Books, 1989. . Untimely Meditations. Trans. R. J. Hollingdale. Cambridge: Cambridge University Press, 1983.

. Twilight of the Idols/The Anti-Christ. Trans. R. J. Hollingdale. London: Penguin Books, 1990.

Onimus, Jean. Albert Camus and Christianity. Trans. Emmett Parker. Tuscaloosa: The University of Alabama Press, 1970.

Orwell, George. Nineteen Eighty-Four. London: Penguin Books, 1990.

Plato. Gorgias. Trans. James H. Nichols. Ithaca: Cornell University Press, 1998. . The Laws of Plato. Trans. Thomas Pangle. Chicago: The University of Chicago Press, 1980.

. Phaedo. In The Collected Dialogues of Plato. Trans. Hugh Tredennick and eds. Edith Hamilton and Huntington Cairns. Princeton: Princeton University Press, 1961. 
Ph.D. - R. Srigley McMaster - Religious Studies . The Republic of Plato. Trans. Allan Bloom. New York: Basic Books, 1968.

. Symposium. In The Dialogues of Plato. Trans. Seth Benardete. London: Bantam Books, 1986.

Quilliot, Roger. The Sea and the Prisons: A Commentary on the Thought of Albert Camus. Trans. Emmett Parker. Tuscaloosa: The University of Alabama, 1970.

Sartre, Jean-Paul. Existentialism and Humanism. Trans. Philip Mairet. Brooklyn: Haskell House Publishers Ltd., 1977.

. Nausea. Trans. Lloyd Alexander. New York: New Directions Publishing Corporation, 1964.

. "Réponse à Albert Camus." Les temps modernes, no. 82 (Août 1952), 334-353.

. Situations IV: Portraits. Paris: Gallimard, 1964.

Scheler, Max. Ressentiment. Trans. William Holdheim. New York: The Free Press of Glencoe, 1961.

Shakespeare, William. The Merchant of Venice. London: Bantam Classics, 1988.

Solomon, Robert C. Dark Feelings, Grim Thoughts: Experience and Reflection in Camus and Sartre. London: Oxford University Press, 2006.

Solzhenitsyn, Aleksandr I. The Gulag Archipelago Two. Trans. Thomas P. Whitney. New York: Harper and Row, Publishers, 1975.

Sprintzen, David. Camus: A Critical Examination. Philadelphia: Temple University Press, 1988. . Sartre and Camus: A Historic Confrontation. Ed. and trans. David Sprintzen and Adrian van den Hoven. New York: Humanity Books, 2004.

Tertullian. The Prescription of Heretics. Trans. T. Herbert Bindley. London: SPCK Publishing, 1914.

Thody, Philip. Albert Camus: 1913-1960. London: Hamish Hamilton, 1961. 
Ph.D. - R. Srigley McMaster - Religious Studies

Thucydides. History of the Peloponnesian War. Trans. Benjamin Jowett. Amherst:

Prometheus Books, 1998.

Todd, Oliver. Albert Camus: A Life. New York: Alfred A. Knopf, 1997.

Voegelin, Eric. Anamnesis. Trans. Gerhart Niemeyer. Columbia: The University of Missouri Press, 1978.

. Conversations. Ed. R. Eric O'Connor. Montreal: Thomas More Institute

Papers, 1980.

.The Collected Works of Eric Voegelin, Volume 11, Published Essays: 1953-

1965, Ed. Ellis Sandoz. Columbia: University of Missouri Press, 2000.

.The Collected Works of Eric Voegelin, Volume 12, Published Essays, 1966-

1985. Baton Rouge: Louisiana State University Press, 1990.

. The Collected Works of Eric Voegelin, Volume 28, What is History? And Other

Late Unpublished Writings. Eds. Thomas Hollweck and Paul Caringella. Baton

Rouge: Louisiana State University Press, 1990.

. Order and History Volume IV: The Ecumenic Age. Baton Rouge: Louisiana

State University Press, 1974.

. The New Science of Politics. Chicago: The University of Chicago Press, 1952.

Ward, Bruce. "Christianity and the Modern Eclipse of Nature: Two Perspectives."

Journal of the American Academy of Religion. 63/4, 823-843.

. "Prometheus or Cain? Albert Camus' Account of the Western Quest for Justice." Faith and Philosophy. Vol.8, No.2 April 1991, 191-213.

. "The Recovery of Helen: Albert Camus's Attempt to Restore the Greek Idea of Nature," Dionysius 14, 1990.

Weber, Max. The Protestant Ethic and the Spirit of Capitalism. Trans. Talcott Parsons. New York: HaperCollins Academic, 1991. 